\author{
UNIVERSIDADE DE SÃO PAULO \\ FACULDADE DE FILOSOFIA, LETRAS E CIÊNCIAS HUMANAS \\ DEPARTAMENTO DE GEOGRAFIA \\ PROGRAMA DE PÓS-GRADUAÇÃO EM GEOGRAFIA HUMANA
}

ELIANE FERREIRA CAMPOS VIEIRA

\title{
A Cartografia no processo de formação acadêmica do professor de Geografia
}

SÃO PAULO

2015 
UNIVERSIDADE DE SÃO PAULO

FACULDADE DE FILOSOFIA, LETRAS E CIÊNCIAS HUMANAS

DEPARTAMENTO DE GEOGRAFIA

PROGRAMA DE PÓS-GRADUAÇÃO EM GEOGRAFIA HUMANA

\title{
A Cartografia no processo de formação acadêmica do professor de Geografia
}

\author{
ELIANE FERREIRA CAMPOS VIEIRA
}

Tese apresentada ao Programa de Pós-graduação em Geografia da Faculdade de Filosofia Letras e Ciências Humanas da Universidade de São Paulo como requisito parcial à obtenção do título de Doutor em Geografia.

Orientador: Prof. Dr. Marcello Martinelli

SÃO PAULO

2015 
Autorizo a reprodução e divulgação total ou parcial deste trabalho, por qualquer meio convencional ou eletrônico, para fins de estudo e pesquisa, desde que citada a fonte.

Vieira, Eliane Ferreira Campos.

A Cartografia no processo de formação acadêmica do professor de Geografia. / Eliane Ferreira Campos Vieira; orientador Marcello Martinelli. - São Paulo, 2015.

$235 \mathrm{f}$. : il.

Tese (Doutorado)--Universidade de São Paulo, 2014.

1. Cartografia 2. Ensino de Geografia 3.Formação de Professores 4. Ensino Superior. I. Martinelli, Marcello. II. A Cartografia no processo de formação acadêmica do professor de Geografia.

CDD 
VIEIRA, E.F.C.. A Cartografia no processo de formação acadêmica do professor de Geografia. Tese apresentada ao Programa de Pós-graduação em Geografia da Faculdade de Filosofia Letras e Ciências Humanas da Universidade de São Paulo como requisito parcial à obtenção do título de Doutor em Geografia.

Aprovado em:

Banca Examinadora

Prof. Dr. Marcello Martinelli - USP - (Orientador)

Julgamento:

Assinatura:

Professora Dra. Sônia Maria Vanzella Castellar Instituição: FAE USP Julgamento:

Assinatura:

Professora Dra. Janete Aparecida Gomes Zuba Instituição: UNIMONTES Julgamento:

Assinatura:

Professora Dra. Maria Isabel Castregini de Freitas Instituição: UNESP Julgamento: Assinatura:

Professora Dra. Carla Cristina Reinaldo Gimenes de Sena UNESP- Ourinhos Julgamento: Assinatura: 
Dedico este trabalho a todos os professores, especialmente aos meus colegas professores de Geografia. 


\section{AGRADECIMENTOS}

Como é gratificante chegar até aqui e ter a certeza de que os esforços ao longo da caminhada concretizaram a realização de um sonho. Certas pessoas nos passam a certeza de que não estamos sozinhos e que a caminhada pode ser prazerosa. Por isso, deixamos registrado aqui algumas singelas palavras que nunca seriam capazes de expressar o tamanho da nossa gratidão a todos aqueles que nos ajudaram suavizando nossos passos e sustentando nossos desafios.

Primeiramente, lembramos do Criador, nosso Deus, nosso Papai do Céu, que na sua infinita bondade concedeu o dom da vida e outros dons que foram sendo aprimorados com o tempo e experiência. Esse grande e maravilhoso Deus me presenteou com pessoas que contribuíram para chegarmos até aqui.

Ao orientador Professor Marcello Martinelli, que com sabedoria, profundo conhecimento, respeito e sensibilidade exerceu com maestria sua tarefa.

Aos familiares com os quais aprendo todos os dias lições de amor, desprendimento e companheirismo, que fazem com que eu me sinta um ser humano privilegiado. À minha mãe Maria, agradecimento especial por cuidar da minha casa e filhos enquanto eu passava horas e horas longe refletindo, viajando, buscando. Ao meu pai Geraldo, por ter sempre acreditado em mim. Ao meus irmãos, Édio e Decinho, sempre solícitos me levando e buscando para horas e horas nas bibliotecas. Às minhas irmãs Sheilinha, Nanta e Piu, que foram grande apoio na fase de $\mathrm{BH}$ ficando com meus filhos enquanto eu estudava. À minha família agregada, os Vieira, agradeço pelo apoio, pelo incentivo e pelo carinho que sempre nos devotaram. À Adriana Rodrigues, minha irmã de Moc City, pela sua presença e torcida...

Ao meu amado Léo e aos meus filhos Natália, Pedro Lucas e Sarinha, agradeço e divido a alegria e todo o fruto desta conquista.

Algumas pessoas ficaram para sempre marcadas em minha mente e coração, as também dedico profunda gratidão pela forma como me acolheram, me ouviram, me mostraram que esse caminho era possível. À Janine Lessan, pelas conversas, pelas palavras de incentivo, pelo seu trabalho que sempre será uma referência. À Janete Zuba, por me receber em sua casa por diversas vezes, pelas conversas e livros emprestados. À Carla Juscélia, da UFSJ por me receber, por me incentivar, por me apoiar. A amiga Renata Guedes, pela sua presença constante mesmo que à distância.

À minha amiga/irmã Rosilene Felbeque, dedico um agradecimento pra lá de especial, pelas leituras, pelas sugestões, pelo incentivo, por todo acompanhamento ao longo desses anos de dedicação a essa tarefa. Muitas 
coisas bonitas não podem ser vistas ou tocadas, elas são sentidas dentro do coração. O que você fez por mim, é uma delas. A sua amizade sempre me fez acreditar que eu era capaz... Valeu demais...

À Evanildo Ferreira da Silva, nosso pastor, agradeço pelo espaço cedido para estudos, e à toda a Igreja Batista Monte Sinai pela torcida e a oração dos irmãos, especialmente nas pessoas de Nayara, Arlete e Thiago. Com vocês encontrei o refúgio de calma e tranquilidade necessário ao longo da preparação dos textos.

À Elizabeth Machado-Hess, por ler o meu trabalho e incentivar a lapidar a pedra bruta. À Dra Lidiane Lúcia João, por entender meus momentos e cuidar de mim.

À FAPEMIG - Fundação de Amparo e Pesquisa de Minas Gerais - agradeço pela concessão da bolsa de estudos que me permitiu maior dedicação na elaboração deste trabalho.

À Secretaria Estadual de Educação de Minas Gerais, pela licença parcial concedida. Especialmente a Alessandro Colares e Adriana Randazzo, sempre cordiais e solícitos às nossas demandas.

Aos colegas do Departamento especialmente Sandra, Gildette, Ana Ivânia, Márcia, Dulce, Anete e todos que compartilharam comigo as angústias dessa trajetória sempre deixando palavras de apoio e incentivo.

Agradecimento especial à Universidade Estadual de Montes Claros, à ProReitoria de Pesquisa. Ao Professor Wagner, naquela oportunidade Chefe do Centro de Ciências Humanas, por defender nosso direito de licença...

Ao Departamento de Geografia da Universidade de São Paulo especialmente à equipe da Coordenação da Pós-Graduação nas pessoas de Jurema e Firmino que, solicitamente nos apoiaram nos momentos de distância.

Ás professoras que participaram da banca examinadora, apresentando suas críticas e sugestões que muito contribuírão para a continuidade de nossa trajetória como professor-pesquisador: Professora Sônia Castellar, Professora Janete Zuba, Professora Maria Isabel Castregini e Professora Carla Sena.

Enfim, a todos que direta ou indiretamente contribuíram para a realização desse trabalho: nossa sincera e eterna gratidão. 
Mudar os rumos do ensino é necessário e possível! Janine Lesann, 2009. In: Geografia no Ensino Fundamental I 


\section{RESUMO}

VIEIRA, E.F.C.. A Cartografia no processo de formação acadêmica do professor de Geografia. 2015. 235 f.Tese (Doutorado). Faculdade de Filosofia Letras e Ciências Humanas, Universidade de São Paulo, 2015.

As discussões em âmbito nacional e internacional sobre a Cartografia Escolar apontam que a compreensão da linguagem cartográfica é passo importante na leitura das realidades geográficas. Tais discussões apontam para a necessidade de se repensar a Cartografia na formação do professor. Esse é o debate que nos interessa e sobre o qual nos debruçamos neste trabalho. Os estudos nesse campo apresentam formulações que abrem problemas específicos, também relevantes, que suscitam ângulos diversos de análise. Norteados por questionamentos acerca da inadequação da formação acadêmica no tocante à Cartografia para os professores, defendemos a seguinte tese: a potencialidade da Cartografia na construção do raciocínio espacial impõe repensar a maneira como os conhecimentos cartográficos são construídos ao longo do processo de formação acadêmica dos professores de Geografia. Diante de tal tese, elegemos como principal foco, investigar o seguinte problema: como deveria ser o ensino de Cartografia no curso de Licenciatura de maneira que os futuros professores fossem capacitados para lidar com os conhecimentos cartográficos no ensino de Geografia? Sendo assim, o objetivo geral dessa pesquisa é analisar as contribuições e limitações das disciplinas específicas de Cartografia no curso de licenciatura em Geografia para o exercício da prática docente. Neste sentido, os objetivos específicos são: i) discutir a Cartografia, a partir da identificação de seus pressupostos teóricos, seu campo de estudo e seu papel como linguagem na Geografia; ii) verificar a estruturação da Cartografia nas orientações curriculares oficiais correntes para o Ensino Fundamental e Médio; iii) investigar a Cartografia como disciplina no processo de formação de professores de Geografia; iv) questionar a estruturação da Cartografia num curso específico de licenciatura em Geografia e refletir sobre suas contribuições para a formação dos professores. Os fundamentos teóricos que orientam a presente pesquisa encontram-se na interface Cartografia, Educação e Geografia. A metodologia utilizada se orienta pela abordagem qualitativa, por acreditar ser esta a melhor via para estabelecer relações entre a formação acadêmica, os conhecimentos cartográficos e o trabalho dos professores com tais conhecimentos no ensino. Como resultado, apresentamos discussões sobre a Cartografia no processo de formação acadêmica do professor de Geografia e elaboramos uma proposta de como deveria ser a abordagem da Cartografia no curso de licenciatura em Geografia.

Palavras-chave: Cartografia - Ensino de Geografia - Formação de Professores - Ensino Superior 
ABSTRACT

The discussions about School Cartography at both the national and the international level lead to the fact that the understanding of the cartographic language is an important step in the reading of geographic realities. These discussions show the need to rethink the Cartography within the teachers' education area. This is the debate which interests us and about which we worked on during this project. The studies in this field point to formulations which create specific and also relevant problems, that stimulate various angles of analysis. We are guided by questionings about the inappropriateness of the academic qualification in relation to Cartography for teachers, therefore we support the following thesis: the potential of Cartography to the building of spatial reasoning forces us to rethink the way through which our cartographic knowledge is built throughout the process of Geography teachers' academic formation. In the face of this thesis, we elected as the main focus to look into the following problem: how the teaching of Cartography in the undergraduate level should be in order to allow future teachers to be able to deal with cartographic knowledge in the teaching of Geography at schools? Thus the general aim in this research is to analyse the contributions and the limitations of specific Cartography subjects on the undergraduate level of the course of Geography in the perfomance of the teaching practice. In this sense, the specific aims are: i) to discuss about Cartography from the identification of its theoretical assumptions, its field of study, and its role as a language in Geography; ii) to verify the structure of Cartography in the current official curricular guidelines for both Elementary and High School; iii) to investigate the Cartography as a subject in the process of formation of Geography teachers; iv) to question about the structure of Cartography on a specific undergraduate Geography course and think about its contributions to the formation of teachers. The theoretical basics which orientate this research are found in the interface Cartography, Education, and Geography. The methodology used is oriented by the qualitative approach since we believe that this is the best way to establish the relationship among academic graduation, cartographic knowledge, and the work of teachers who possess such knowledge in the teaching process. As a result, we present discussions about Cartography in the process of formation of a Geography teacher and we also elaborate a suggestion of how the approach of Cartography on a Geography Undergraduate Course should be.

Keywords: Cartography - Geography teaching - Teachers' formation - Higher Education 


\section{LISTA DE FIGURAS}

FIGURA 1 - Mesorregiões de Minas Gerais ……............................................ 23

FIGURA 2 - Montes Claros no norte de Minas Gerais ....................................... 25

FIGURA 3 - Estruturação da Pesquisa em Cartografia Escolar ........................... 31

FIGURA 4 - A tríade da Cartografia Escolar .................................................... 32

FIGURA 5 - A Cartografia Escolar ............................................................. 33

FIGURA 6 - Os campos de estudo da Cartografia, conforme Castro (2012) ....... 54

FIGURA 7 - Mapeamento como um processo de comunicação, segundo

Salichtchev (1978)

FIGURA 8 - A visualização cartográfica de MacEachren (1994)

64

FIGURA 9 - Base conceitual para a Cartografia, conforme Taylor ...................... 65

FIGURA 10 - PCNs Ensino Fundamental ...................................................... 80

FIGURA 11 - Tripé do ensino tradicional, proposto por Biddle ............................ 88

FIGURA 12 - Processo de aquisição do conhecimento geográfico: da Geografia à representação do espaço geográfico

FIGURA 13 - Mapa da questão 7a.............................................................. 171

FIGURA 14 - Mapa da questão 7a............................................................ 171 


\section{LISTA DE QUADROS}

QUADRO 1: Objetivos, itens e procedimentos ligados à Cartografia, nos PCNs do $1^{\circ}$ e $2^{\circ}$ ciclos do Ensino Fundamental

QUADRO 2: Atividades e respectivos conhecimentos relativos à representação do espaço

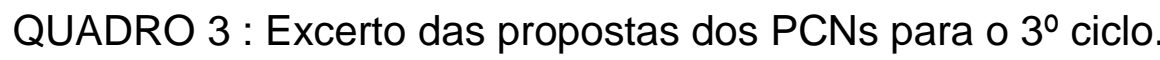
93

QUADRO 4: Conceito de escala. 98

QUADRO 5: Tópicos e habilidades relacionados à Cartografia no $\mathrm{CBC}$ para o Ensino Fundamental 105

QUADRO 6: Tópicos e habilidades relacionados à Cartografia no $\mathrm{CBC}$ Ensino Médio 106

QUADRO 7: Tópicos e habilidades relacionados à Cartografia no Conteúdo Complementar de Geografia para o Ensino Médio

QUADRO 8: Estrutura curricular do curso de licenciatura em Geografia na UNIMONTES (1964-1971)

QUADRO 9: Competências e habilidades estabelecidas pelas DCNMEC para os cursos de Graduação em Geografia

QUADRO 10 - A disciplina Cartografia nos PPPs 2002, 2004 e 2008 do curso de Licenciatura em Geografia da UNIMONTES

QUADRO 11 - A disciplina Cartografia Temática nos PPPs 2002, 2004 e 2008 .. 155

QUADRO 12 - A disciplina Geoprocessamento nos PPPs 2002, 2004 e 2008 ... 156 


\section{LISTA DE ABREVIATURAS E SIGLAS}

$\mathrm{ACl}$ - Associação Cartográfica Internacional

BIRD - Banco Internacional de Reconstrução e Desenvolvimento

BM - Banco Mundial

CBC - Conteúdo Básico Comum

CES - Câmara de Educação Superior

CLT Consolidação das Leis do Trabalho

CNE - Conselho Nacional de Educação

$\mathrm{CP}$ - Conselho Pleno

DCNMEC - Diretrizes Curriculares Nacionais do Ministério da Educação

ENADE - Exame Nacional de Cursos

ENEM - Exame Nacional de Ensino Médio

FMI - Fundo Monetário Internacional

FUNBEB - Fundo de Manutenção e Desenvolvimento da Educação Básica

FUNDEF - Fundo de Manutenção e Desenvolvimento do Ensino Fundamental e de Valorização do Magistério

GIS - Geographic Information System

GPS - Global Positioning System

IBGE - Instituto Brasileiro de Geografia e Estatística

LDBEN - Lei de Diretrizes e Bases da Educação Nacional

MEC - Ministério da Educação e Cultura

ONU - Organização das Nações Unidas

PAAE - Programa de Avaliação da Aprendizagem Escolar

PCN - Parâmetros Curriculares Nacionais

PPP - Projeto Político Pedagógico

PROEB - Programa de Avaliação da Educação Básica

SAEB - Sistema Nacional de Avaliação da Educação Básica

SEE-MG -Secretaria de Educação do Estado de Minas Gerais

SUDENE - Superintendência de Desenvolvimento do Nordeste

UFSC - Universidade Federal de Santa Catarina

UNIMONTES - Universidade Estadual de Montes Claros 


\section{SUMÁRIO}

INTRODUÇÃO

I. CARTOGRAFIA: HISTÓRIA E EVOLUÇÃO METODOLÓGICA ….......................31

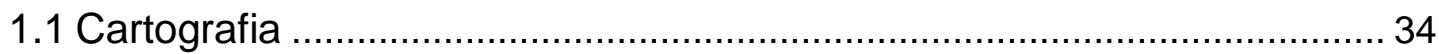

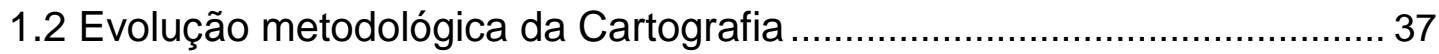

1.3 Refletindo sobre algumas definições de Cartografia................................. 45

1.4 Correntes Teórico-metodológicas da Cartografia .......................................5 55

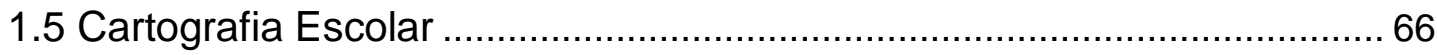

II. A CARTOGRAFIA NAS ORIENTAÇÕES CURRICULARES PARA A GEOGRAFIA NO ENSINO FUNDAMENTAL E MÉDIO …….................................

2.1 Parâmetros Curriculares Nacionais............................................................ 76

2.1.1 Pressupostos teóricos orientadores da proposta dos PCNs ................77

2.1.2 A Cartografia Ensino Fundamental I conforme os PCNs ......................79

2.1.3 A Cartografia no Ensino Fundamental II conforme os PCNs ................91

2.1.4 A Cartografia no Ensino Médio conforme os PCNs ............................97

2.2 O Conteúdo Básico Comum: Proposta Curricular do Estado de

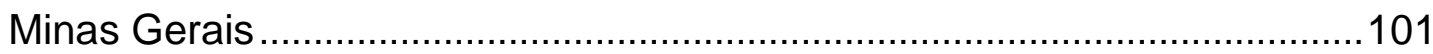

2.2.1 Conteúdo Complementar de Geografia ..........................................107

III. A CARTOGRAFIA NA FORMAÇÃO DO PROFESSOR DE GEOGRAFIA .......111

3.1 As reformas curriculares no contexto educacional brasileiro .................. 112

3.2 Reformas curriculares e a formação docente ………………………..... 120

3.3 Estado da arte da Cartografia na formação docente............................... 127

3.4 Cartografia na formação do professor do Ensino Fundamental I ......... 129

3.5 Cartografia na formação do professor de Geografia.............................. 135

IV A CARTOGRAFIA NO CURSO DE LICENCIATURA EM GEOGRAFIA: UM ESTUDO DE CASO 
4.1 Opções e caminhos metodológicos

4.2 Organização curricular do curso de Licenciatura em Geografia da UNIMONTES.

4.2.1 A Cartografia nos Projetos Político-Pedagógicos 2002, 2004, 2008 153

4.3 Conhecimentos cartográficos dos acadêmicos do curso de Geografia na UNIMONTES 159

4.3.1 Análise das respostas dos graduandos aos questionários 160

4.4 Refletindo sobre o estudo de caso 174

CONSIDERAÇÕES FINAIS 176

REFERÊNCIAS 180

APÊNDICES 194

ANEXOS 210 


\section{INTRODUÇÃO}

A profissão de professor é um desafio constante e permanente, para a qual o professor-pesquisador é instigado a prosseguir, a partir das perguntas que lhes são apresentadas pela prática do dia-a-dia, na vida pessoal, na sala de aula, no contexto do ambiente que o cerca. Este trabalho é fruto de uma trajetória, cujo processo tem como centro do debate o ensino de Geografia na sala de aula e, mais especificamente, sobre a Cartografia Escolar como uma linguagem a ser experienciada desde o início da escolaridade.

A discussão da Cartografia e do Ensino de Geografia não é tão recente quanto alguns possam presumir. Nossa principal referência para esse campo de estudo constituem os trabalhos de Lessan $(2001,2009,2010)$ entre outros. Um dos principais temas pesquisados por Lessan giravam em torno da produção e da utilização de materiais didáticos, como os Atlas Escolares Municipais. Tais Atlas apresentavam atividades que, abordando diferentes temas como clima, uso do solo, relevo, hidrografia, ensino, saúde, população, agricultura e pecuária, entre outros, tinham o objetivo de iniciar e instrumentalizar o aluno no processo de pesquisa para capacitá-lo a "aprender a aprender".

Em participação no Projeto Atlas Escolares Municipais (LESANN, 2001), e em contato com pesquisas em torno da utilização dos Atlas pelos alunos, foi identificada a necessidade de aprimoramento da prancha referente ao relevo. Uma dessas pesquisas é a de Felbeque (2003), na qual a autora observou dificuldades de os alunos perceberem que as formas de relevo representadas em fotografias panorâmicas, mapas pictóricos e curvas de nível correspondiam a elementos da paisagem ao seu redor.

As discussões em âmbito nacional e internacional sobre a Cartografia Escolar apontam que a compreensão da linguagem cartográfica é passo importante na leitura das realidades geográficas. Tais discussões apontam para a necessidade de se repensar a Cartografia na formação do Professor. Esse é o 
debate que nos interessa e sobre o qual nos debruçamos neste trabalho. Os estudos nesse campo apresentam formulações que abrem problemas específicos, também relevantes, que suscitam ângulos diversos de análise.

Quando discutimos “o bloco-diagrama na representação do relevo no 1ํano do Ensino Médio: uma análise a partir dos recursos cartográficos presentes em livros didáticos de Geografia" (VIEIRA, 2005), além de analisar as contribuições e os limites de utilização do bloco-diagrama na representação do relevo no ensino de Geografia, chegamos a considerar que a construção do raciocínio geográfico, a partir da Cartografia, depende, em certa medida, do professor.

Isso quer dizer que o professor de Geografia, para construir conhecimento com seus alunos a partir da Cartografia, precisa compreender que as representações cartográficas - e seu significado - devem ser abordados por meio de um trabalho de leitura e de compreensão do texto cartográfico - que é misto -, já que usa a linguagem verbal (palavras) e a gráfica (pontos, linhas e áreas). Pela nossa prática como professor formador nos cursos de graduação em Geografia e como professor no Ensino Fundamental e Médio, sabemos que para uma boa parte dos professores, a Cartografia é ainda um conhecimento a ser assimilado.

Diante da potencialidade da Cartografia, novas questões nos inquietam: acaso, estaria na formação acadêmica a raiz da dificuldade de os professores de Geografia utilizarem o potencial da Cartografia no exercício de sua prática docente?

Esses questionamentos mostraram-se intrigantes e passíveis de discussão ao longo da nossa trajetória como professora no Ensino Superior no curso de Graduação em Geografia, iniciada em 2004 ${ }^{1}$. Nossa experiência nesse nível de ensino também permitiu perceber a necessidade de reflexão sobre a

\footnotetext{
${ }^{1}$ Nesse mesmo ano, assumimos também o cargo de Professor da Educação Básica na Secretaria Estadual de Educação de Minas Gerais e vim até a presente data, trilhando as duas esferas do ensino de Geografia - a Educação Básica e o Ensino Superior. A caminhada árdua é norteada por questionamentos que nos direcionam no sentido de articular a teoria com a prática, num ir e vir comum ao professor-pesquisador.
} 
Cartografia como uma linguagem a ser conhecida e experienciada pelos futuros professores.

Norteados pelos questionamentos acerca da inadequação da formação acadêmica dos professores em Cartografia, discutimos a importância dessa disciplina na formação do professor de Geografia, a partir da análise da estrutura curricular de diversos cursos de Geografia de algumas instituições de ensino superior brasileiras que ofereciam a formação de licenciatura em Geografia (VIEIRA e CASTRO, 2010).

Ao analisar a estrutura curricular de cursos de Licenciatura em Geografia, discutimos o distanciamento existente entre a Cartografia que se aprende na academia e a que é necessária para que os alunos do Ensino Fundamental aprendam ao final das etapas de escolarização (VIEIRA e CASTRO, 2010).

Também observamos que, na maioria dos cursos de graduação em Licenciatura em Geografia não existe disciplina específica voltada para o ensino de Cartografia para os níveis fundamental e médio. Daí surgiu o seguinte questionamento: os futuros professores aprendem a Cartografia de maneira que possam abordá-la como uma linguagem na leitura das realidades espaciais junto com seus alunos?

Inquietava-nos a ideia de que o aprendizado ineficiente dos professores de Geografia poderia traduzir-se em uma deficiente aprendizagem cartográfica dos alunos egressos da Educação Básica. Passamos a considerar que os conhecimentos sobre a Cartografia que o professor recebe no curso de formação em Licenciatura seriam insuficientes para os desafios com os quais os professores se deparariam ao ensinar a espacialidade da Geografia para alunos do Ensino Fundamental e Médio.

Considerando as inquietações do estudo anterior (VIEIRA e CASTRO, 2010), e refletindo sobre as habilidades cartográficas necessárias ao professor da Educação Básica, percebemos que poderia estar na formação acadêmica uma deficiência em relação aos conhecimentos cartográficos do professor de Geografia. 
Essas indagações também foram percebidas quando atuamos como professora de disciplinas nos períodos mais adiantados do curso de Licenciatura em Geografia na Universidade Estadual de Montes Claros (UNIMONTES). Nessa oportunidade, deparamo-nos com questionamentos dos graduandos em relação ao trabalho com os conhecimentos cartográficos no ensino de Geografia. De maneira geral, os alunos consideravam que as disciplinas específicas de Cartografia não abordavam questões práticas e teóricas relevantes para seu ensino.

Atuando nesse curso, observamos que os graduandos não apresentavam determinadas aprendizagens relativas à Cartografia. Em sala de aula, em momentos em que se demandou a mobilização de conhecimentos cartográficos, apesar de instigados e interessados na execução das atividades, esses alunos demonstravam-se inseguros, uma vez que, do ponto de vista prático da aprendizagem da Cartografia, pouco tinham feito até então. Faltava aos alunos pré-requisitos para a construção da noção de espaço e sua respectiva representação. Tal fato apontou para a seguinte questão: se os graduandos não apreendem os conteúdos da Cartografia Escolar ao longo do curso de Licenciatura em Geografia, como vão ensiná-la na Educação Básica?

Entendemos que as questões que se apresentavam no curso de Geografia da UNIMONTES poderiam ocorrer em outras instituições Brasil afora, posto que os cursos de Licenciatura no nosso país seguem a mesma estruturação curricular com disciplinas muito parecidas. Por isso, no nosso entendimento, tais questionamentos seriam passíveis de aplicação na realidade dos cursos de Licenciatura em Geografia em âmbito nacional. Esse seria mais um elemento que impulsionava a presente pesquisa.

A Cartografia entendida como uma linguagem pode permitir 0 acesso a diferentes instrumentos para desvendar e compreender a realidade do mundo. Com isso, é possível dar mais sentido e significado à aprendizagem, pois as representações cartográficas têm importante papel na construção do raciocínio espacial. 
Tendo como orientação os questionamentos apresentados, pretendemos com este trabalho defender a seguinte tese: a potencialidade da Cartografia na construção do raciocínio espacial impõe repensar a maneira como os conhecimentos cartográficos são construídos ao longo do processo de formação acadêmica dos professores de Geografia.

Diante de tal tese, elegemos como principal foco, investigar o seguinte problema: como deveria ser o ensino de Cartografia no curso de Licenciatura, de maneira que os futuros professores fossem capacitados para lidar com os conhecimentos cartográficos no ensino de Geografia?

Sendo assim, o objetivo geral desta tese é analisar as contribuições e limitações das disciplinas específicas de Cartografia no curso de Licenciatura em Geografia para o exercício da prática docente. Neste sentido, os objetivos específicos são:

- discutir a Cartografia, a partir da identificação de seus pressupostos teóricos, seu campo de estudo e seu papel como linguagem na Geografia;

- verificar a estruturação da Cartografia nas orientações curriculares oficiais correntes para o Ensino Fundamental e Médio;

- investigar a Cartografia como disciplina no processo de formação de professores de Geografia;

- questionar a estruturação da Cartografia num curso específico de Licenciatura em Geografia e refletir sobre suas contribuições para a formação dos professores.

A discussão do tema aqui apresentado justifica-se por diversas razões. A primeira delas refere-se ao fato de a representação do espaço ocorrer desde os primórdios da humanidade, estando os mapas entre as mais antigas formas de comunicação entre as pessoas (HARLEY,1991: 5). 
Ao longo de sua história, a Cartografia constituiu-se como um vasto conhecimento que muito contribuiu para a emergência e a institucionalização da Geografia como ciência. Apesar de recentemente ter experimentado uma renovação com a introdução de modernas tecnologias como as fotografias áreas e as imagens produzidas por satélites, não podemos afirmar que a Geografia utilize bem e melhor a linguagem cartográfica (FONSECA, 2004).

Dessa forma, a Cartografia é ainda um conhecimento a ser desvendado por estudiosos de diversas áreas e especialmente pelos professores de Geografia. O desenvolvimento dos conhecimentos cartográficos na Educação Básica é um tema a ser discutido principalmente no que diz respeito ao ensino de Geografia.

Diversos autores (PAGANELLI, 1982; LESANN, 1989; SIMIELLI, 1993; ALMEIDA, PASSINI, 1994; CASTELLAR, 1996; MARTINELLI, 2010) dedicaram-se a pesquisas sobre as possibilidades da Cartografia nas séries iniciais. Muitos desses estudos apontam que a Cartografia deve ser utilizada não como um conteúdo, mas sim como uma linguagem, a partir da leitura das realidades vivenciadas pelos alunos.

Com este trabalho, também esperamos contribuir para a produção do conhecimento da ciência geográfica, pois consideramos o mapa como um texto - não apenas um desenho, mas um conjunto de informações verbais e não verbais - e a Cartografia como uma linguagem de representação e de interpretação crítica da realidade. A leitura, pois, de um mapa - como a de qualquer texto - ultrapassa a mera decodificação de símbolos, conforme ensinou Bertin (1973), ao preconizar que é necessário ver a relação entre os significados dos símbolos para entender a informação que será revelada pelo mapa.

Ainda há de se destacar que a Geografia como ciência tem um papel central no entendimento do espaço em constante mudança. Dessa forma, as habilidades inerentes à leitura cartográfica constituem um importante instrumento para a interpretação crítica da realidade. Por isso, este trabalho também se justifica por promover um diálogo entre os resultados das pesquisas sobre a Cartografia e assim contribuir com a reflexão sobre a formação acadêmica de professores. 
Os fundamentos teóricos que orientam a presente pesquisa encontram-se na interface Cartografia, Educação e Geografia. Para Almeida (2010), os estudos sobre Geografia e Cartografia Escolar são delimitados por conhecimentos das Ciências Humanas relacionadas com a Educação; das Ciências da Linguagem e das Ciências de referência, no caso, Geografia e Cartografia, os quais procuramos desenvolver ao longo do texto.

Os caminhos da presente pesquisa sinalizam uma opção metodológica que se orienta pela abordagem qualitativa, por acreditar ser esta a melhor via para estabelecer relações entre a formação acadêmica, os conhecimentos cartográficos e o trabalho dos professores com tais conhecimentos no ensino. Tal opção justifica-se em função da natureza do objeto estudado: a Cartografia no processo de formação acadêmica de professores de Geografia.

A pesquisa qualitativa constitui-se num método de investigação de enfoque diferente daqueles empregados tradicionalmente. Fazem parte dessa abordagem a pesquisa participativa, a pesquisa-ação, a pesquisa etnográfica e o estudo de caso (LÜDKE; ANDRÉ, 1986). São características básicas desse tipo de estudo: i) os dados coletados são predominantemente descritivos; ii) a preocupação com o processo é muito maior do que com o produto, ou seja, verifica-se como um determinado problema se manifesta nas atividades, nos procedimentos e nas interações cotidianas; iii) o ambiente natural como fonte direta dos dados; iv) enfoque indutivo. Dessa forma, "os investigadores qualitativos tentam compreender o processo mediante o qual as pessoas constroem significados" (BOGDAN; BIKLEN, 1994).

Além do recorte espacial, em se tratando de pesquisa social, o
lugar primordial é o ocupado pelas pessoas e grupos
convivendo numa dinâmica de interação social. Essas pessoas
e esses grupos são sujeitos de uma determinada história a ser
investigada, sendo necessária uma construção teórica para
transformá-los em objetos de estudo. Partindo da construção
teórica do objeto de estudo, o campo torna-se um palco de
manifestações de intersubjetividades e interações entre
pesquisador e grupos estudados, propiciando a criação de
novos conhecimentos (CRUZ NETO, 1994: 54).

Uma das possibilidades de se entender a realidade do curso de Licenciatura em Geografia da UNIMONTES é partir de um recorte mais amplo, que 
caracterize o estado de Minas Gerais, o qual apresenta uma heterogeneidade peculiar, e é marcado por uma intensa diversidade regional nos aspectos socioeconômicos e nas características naturais, na qual se conformam os seus 853 municípios. Tal diversidade estabeleceu-se ao longo de um processo que remonta ao tempo das capitanias das Minas Gerais, em meados do século XVIII, período no qual o território hoje denominado Minas Gerais era constituído por extensas áreas de sertão, currais, campos e matas, que davam suporte a atividades econômicas também diversificadas como a criação de gado e a exploração mineral.

Do ponto de vista administrativo, o Estado é dividido em regiões de planejamento. Dentre essas, a região norte de Minas diferencia-se por suas características fisiográficas, pelas condições socioeconômicas e pela constante intervenção estatal (PEREIRA, 2007). A Figura 1 mostra as Mesorregiões de Minas Gerais.

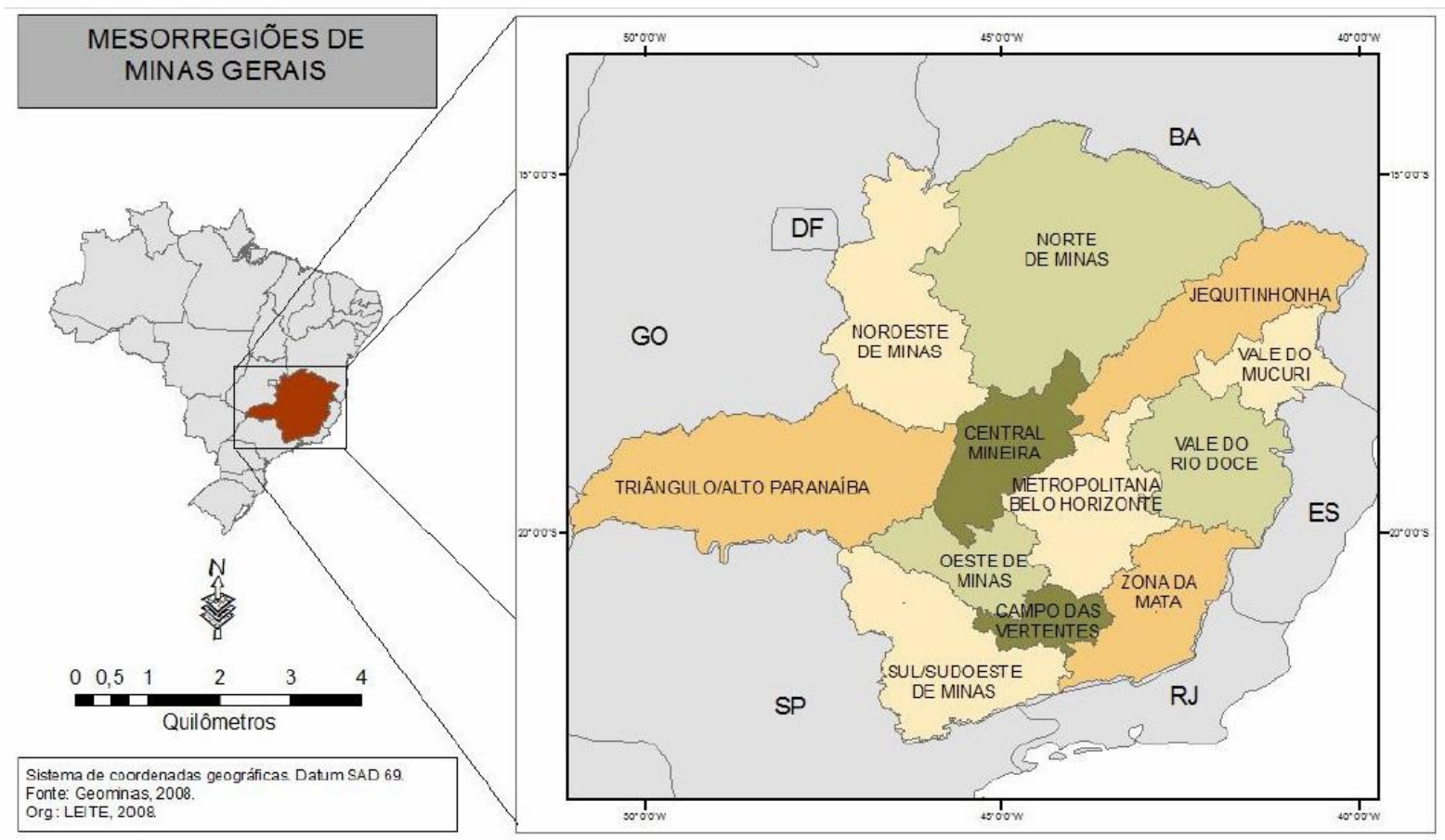

Figura 1 - Mesorregiões de Minas Gerais Fonte: Leite (2011: 124).

É possível identificar visões diferentes sobre a região norte de Minas, "ora descrita como cheia de potencialidade, ora como bolsão de pobreza" (PEREIRA, 2007: 94). 
Viajando pelo norte de Minas não podemos deixar de dar razão a essa visão dualista da região, através da qual identificamos, concomitantemente, muita pobreza e nichos de riqueza, modernidade e tradicionalismo, produção e escassez, discursos e realidade. Entretanto, questionamos até que ponto os rótulos utilizados para caracterizar a região são verdadeiros ou são uma criação ideológica para atender a determinados interesses de uma classe social. Nessa nossa análise, não podemos desconsiderar a lógica capitalista que interfere, de maneira direta ou indireta, na região. É essa lógica que explica a escolha de pontos estratégicos pelos grandes capitais internacionais para seus investimentos, além do aumento do consumo de bens e serviços, mudança nos valores e nas práticas socioespaciais (PEREIRA, 2007: 95).

Do ponto de vista físico, a região norte de Minas caracteriza-se como área de transição do domínio do ecossistema do cerrado para o da caatinga. As bacias hidrográficas mais importantes na região são as dos rios São Francisco, Jequitinhonha e Pardo, cujos afluentes caracterizam-se pela intermitência de seus leitos, o que agrava periodicamente a seca na região. O clima é marcado por má distribuição de chuvas, o que justificaria a inclusão da região no Polígono das Secas e na área de atuação da Superintendência de Desenvolvimento do Nordeste (SUDENE) (PEREIRA, 2007).

A população da região norte de Minas distribui-se irregularmente nos municípios, com maior concentração nas cidades de Pirapora e de Montes Claros, compondo uma sociedade marcada por intensas desigualdades dentro da região e mesmo nos municípios de economia mais diversificada. Na maior parte dos municípios predomina a agricultura de subsistência, a silvicultura e a pecuária de corte.

Inserido na mesorregião norte e microrregião de Montes Claros, o município de Montes Claros ocupa lugar de destaque, uma vez que representa um centro polarizador em toda a região, estendendo-se ao sul da Bahia. Com uma área territorial de 3.594,1 km², o município de Montes Claros destaca-se "como polo, contando com grande dinamismo de seu comércio, transportes e estabelecimentos hospitalares e de ensino superior" (PEREIRA, 2007: 113).

A centralidade econômica de Montes Claros na região norte de Minas vale-se de sua localização "entre entroncamento de importantes eixos rodoviários, o 
que facilita a realização de contínuos fluxos entre os municípios vizinhos" (PEREIRA, 2007: 129). (Ver FIGURA 2).

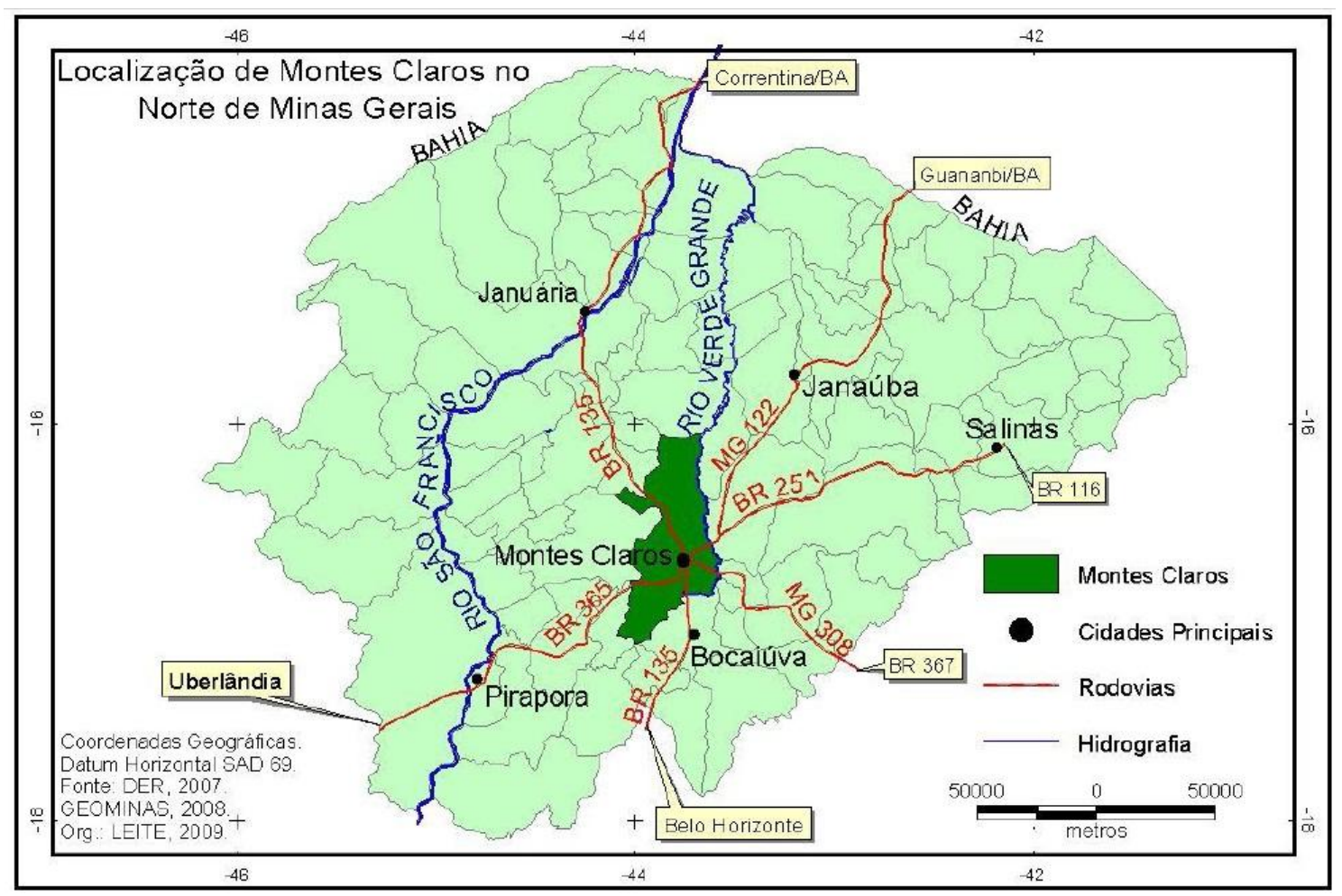

Figura 2 - Montes Claros no norte de Minas Gerais Fonte: Leite (2011: 124).

De acordo com o censo demográfico do Instituto Brasileiro de Geografia e Estatística (BRASIL, 2010), a população é de 361.915 habitantes, sendo que apenas $4,83 \%$ desse total residem na área rural. Nas últimas décadas, a sede do município tem experimentado um intenso processo de crescimento urbano que se reflete sobre a situação ambiental.

A Universidade Estadual de Montes Claros destaca-se por atender às regiões norte e noroeste do Estado de Minas Gerais, Vale do Jequitinhonha, do Mucuri e do Urucuia, com influência até o sul do estado da Bahia. As condições sociais na área de atuação da UNIMONTES fazem com que suas ações sejam vistas como instrumento de transformação da realidade para o desenvolvimento socioeconômico (ZUBA, 2006).

Zuba (2013: 23) afirma que: 
A área de atuação da UNIMONTES representa cerca de 44,3\% da área do Estado e atende clientela oriunda de uma população que ultrapassa os 3,01 milhões de habitantes ou $15,63 \%$ da população mineira. Além das regiões supracitadas, a UNIMONTES atende a uma significativa parcela de alunos advindos do sul da Bahia, transformando Montes Claros num polo estudantil de grande importância regional e interestadual.

Ao discutir a Cartografia no processo de formação acadêmica do professor de Geografia, teremos como estudo de caso o curso de Licenciatura em Geografia da UNIMONTES.

O estudo de caso em uma pesquisa na área da Educação pode ser definido pelo processo no qual o professor-pesquisador procura

[...] entender um fato ou uma circunstância que afeta o ensino, detendo-se sobre ele para compreendê-lo melhor, no contexto imediato em que acontece, a fim de apresentarem um relatório consistente ou descrevê-lo com informações documentadas. Esses estudos tomam como objeto uma questão circunscrita e específica - seja um aluno, uma sala de aula, uma escola (CHIZZOTTI, 2001: 110).

É característica do estudo de caso o teor crítico, na medida em que permite confirmar, modificar, ou ampliar o conhecimento sobre o objeto estudado.

A coleta de dados para um estudo de caso pode ir de uma observação, de uma entrevista à pesquisa documental. Segundo Chizzotti (2001), a pesquisa documental é uma fase do esforço da pesquisa e envolve a identificação e a análise das informações contidas em textos ou outros registros. Conforme Bodgan e Biklen (1994: 180), na utilização de documentos oficiais para análise documental, "os investigadores podem ter acesso à perspectiva oficial" de uma instituição, acerca de uma determinada concepção ou conceito.

São considerados também documentos, a categoria que compreende "textos escritos pelos sujeitos", entre os quais incluem-se memorandos, minutas de encontros, boletins informativos, documentos sobre políticas, propostas, códigos de ética, dossiês, registros de estudantes, declarações de filosofia, comunicados à imprensa e coisas semelhantes (BODGAN; BIKLEN, 1994: 180). 
Orientando-nos pelos pressupostos da pesquisa qualitativa, o plano de investigação deste estudo contemplou: i) Revisão bibliográfica, que envolveu levantamento, caracterização e discussão da história da Cartografia, da caracterização da Cartografia na atualidade e da Cartografia temática; o Ensino de Geografia e a análise dos estudos da Cartografia Escolar; ii) Pesquisa e seleção de documentos para análise documental: documentos oficiais da Educação; Diretrizes Curriculares Nacionais para os Cursos de Formação de Professores da Educação Básica, Parâmetros curriculares Nacionais e Conteúdo Básico Curricular (CBC) proposta curricular da Secretaria de Estado da Educação de Minas Gerais (SEEMG); do Projeto Político-pedagógico e discussão da estrutura curricular do Curso de Geografia da UNIMONTES. Nesse último documento, procuramos identificar a presença da Cartografia, qual profissional se deseja formar e, se a Cartografia e todo seu potencial estariam presentes nesse curso.

Em outra fase da metodologia fizemos a opção pela aplicação de questionário junto aos alunos do curso de Licenciatura em Geografia da Universidade Estadual de Montes Claros, com o objetivo de verificar a apreensão de conceitos relacionados à Cartografia, por um grupo de 63 graduandos do curso de Geografia da Universidade Estadual de Montes Claros, matriculados no campus sede em Montes Claros.

Ao discutir a Cartografia nos cursos de Licenciatura em Geografia, tivemos como ponto de partida a Cartografia - sua estrutura e apreensão pelos futuros professores - vivenciada no curso de Geografia da UNIMONTES. Procuramos, dessa forma, partindo da leitura do lugar onde estamos, tentar compreender 0 todo num processo dialético. A justificativa para o ponto de partida desta tese pode ser compreendida nos dizeres de Gamboa (2007: 42):

Nas ciências sociais como na Educação, tanto o investigador como os investigados (grupo de alunos, comunidade ou povo) são sujeitos; o objeto é a realidade. A realidade é um ponto de partida e serve como elemento mediador entre os sujeitos. Numa relação dialógica e simpática como é o caso do processo de pesquisa. Esses sujeitos se encontram juntos ante uma realidade que Ihes é comum e que os desafia para ser conhecida e transformada. 
De acordo com a metodologia qualitativa, o campo de pesquisa apresenta-se como possibilidade de o pesquisador aproximar-se do objeto de estudo, conhecê-lo e estudá-lo a partir de seu espaço de vivência. Essa percepção possibilita ao pesquisador conhecer os limites e as diferentes realidades existentes no cotidiano, e com isso visualizar um leque de procedimentos e descobertas, pois

Os investigadores qualitativos não recolhem dados ou provas com o objetivo de confirmar ou informar hipóteses construídas previamente; ao invés disso, as abstrações são construídas à medida que os dados particulares que foram recolhidos vão se agrupando (BODGAN; BIKLEN, 1994: 50).

O campo de estudo é um recorte em que o pesquisador utiliza um contexto social que vai representar empiricamente a realidade a ser estudada, uma vez que esse recorte é ocupado por pessoas e grupos que convivem numa dinâmica de interação social e são sujeitos de um determinado problema a ser estudado:

[...] Concebemos como campo de pesquisa o recorte que o pesquisador faz em termos de espaço, representando uma realidade empírica a ser estudada a partir das concepções teóricas que fundamentam o objeto da investigação (CRUZ NETO, 1994:53).

Desse modo - e, não somente por razões práticas -, estabelecemos como campo de pesquisa a Cartografia ministrada nos cursos de Licenciatura em Geografia da Universidade Estadual de Montes Claros (UNIMONTES), dada a atuação regional e interestadual dessa universidade, como já nos referimos acima.

Entendemos que a relação entre os saberes geográfico e cartográfico dá-se a partir de uma construção social, na qual estão envolvidos vários sujeitos, políticas diversas, outros saberes e percepções do que compõe a realidade. Sendo assim este trabalho está organizado em quatro capítulos.

O primeiro capítulo intitulado "Cartografia: História e Evolução Metodológica" constitui a expressão de nossa compreensão da Cartografia, ressaltando a evolução metodológica dessa área de conhecimento. Para tanto, discutimos algumas definições de Cartografia, procurando evidenciar que as diversas 
definições permitem compreender as contribuições históricas ao processo de estruturação da Cartografia. Destacamos também os fundamentos predominantes nessa ciência, por meio de uma reflexão sobre as correntes teórico-metodológicas da Cartografia, marcados por cinco paradigmas: o paradigma positivista, o da teoria da comunicação cartográfica, o de influência fenomenológica, o estruturalista e o paradigma da visualização cartográfica. Ainda no primeiro capítulo discutimos a Cartografia escolar, mostrando-a no contexto dos demais estudos que orientam nossas concepções.

No segundo capítulo, apresentamos uma reflexão sobre a Cartografia nas orientações curriculares oficiais. Considerando a realidade escolar em que atuamos, a Educação Básica na rede estadual em Minas Gerais, fizemos uma análise dos Parâmetros Curriculares Nacionais e do Conteúdo Básico Comum, proposta curricular do Estado de Minas Gerais. Partindo do pressuposto de que as propostas oficiais, em certa medida, ainda que datadas ou desatualizadas, orientam o trabalho dos professores, procuramos evidenciar como a Cartografia aparece nessas orientações. Nosso objetivo foi também apontar a necessidade de um repensar as novas propostas que expressam a Cartografia como linguagem na leitura das espacialidades contempladas pela abordagem geográfica.

No terceiro capítulo discutimos o estado da arte da Cartografia no processo de formação docente, assim incluída a Cartografia na formação do professor do Ensino Fundamental I. Ainda apresentamos nesse capítulo as pesquisas e as referências que tratam da Cartografia na formação do professor de Geografia.

O quarto capítulo constitui o estudo de caso proposto sobre a Cartografia no curso de Licenciatura em Geografia da UNIMONTES. O texto expressa uma compreensão da estruturação da Cartografia nesse curso, fundada na análise de seus vários Projetos Político-pedagógicos. Como tentativa de apreender a Cartografia na visão dos acadêmicos desse curso, realizamos o levantamento de alguns conhecimentos cartográficos de tais sujeitos, o que permitiu elaborar algumas conjecturas e inferências sobre a necessidade de se repensar a 
maneira como os conhecimentos cartográficos são trabalhados ao longo do processo de formação acadêmica dos professores de Geografia.

Nas considerações finais, apresentamos algumas reflexões sobre a Cartografia no processo de formação acadêmica do professor de Geografia. Diante das reflexões empreendidas neste estudo, elaboramos uma proposta de como deveria ser a abordagem da Cartografia no curso de Licenciatura.

Finalmente, declaramos nossa compreensão de que, evidentemente, há problemas não resolvidos e dificuldades não superadas nas discussões aqui realizadas. Assumimos integralmente a responsabilidade daquilo de que estamos cientes, indicando apenas nosso interesse e nosso propósito de prosseguir nestas investigações, sem dúvida encontrando novos problemas e dificuldades, que são afinal, a matéria mesma do trabalho filosófico. 


\section{I - CARTOGRAFIA: HISTÓRIA E EVOLUÇÃO METODOLÓGICA}

Se ainda se pretende a educação a favor de um mundo social mais justo, é preciso orientar o trabalho pedagógico com base em uma visão de futuro, em uma perspectiva utópica que desafie os limites do estabelecido, que afronte o real, que esboce um novo horizonte de possibilidades.

Antônio Flávio Barbosa Moreira

Pesquisas sobre Cartografia Escolar no Brasil apresentam, na atualidade, uma produção numerosamente significativa que surgiram a partir de meados da década de 70, decorrentes de teses e dissertações (OLIVEIRA, 1978; PAGANELI, 1982; SIMIELLI, 1986; ALMEIDA e PASSINI, 1994; ALMEIDA, 1994; CASTELLAR, 1996; PASSINI, 1998; MARTINELLI, 1998; ALMEIDA, 2001; LESANN, 2009; e outros). Esses estudos possibilitaram um avanço na estruturação teórica e metodológica dos estudos nesse campo.

Para Almeida (2007), os estudos no campo da Cartografia Escolar constituíamse em uma área de ensino e em uma área de pesquisa que se estabeleceriam na interface Educação, Geografia e Cartografia, conforme a Figura 3.

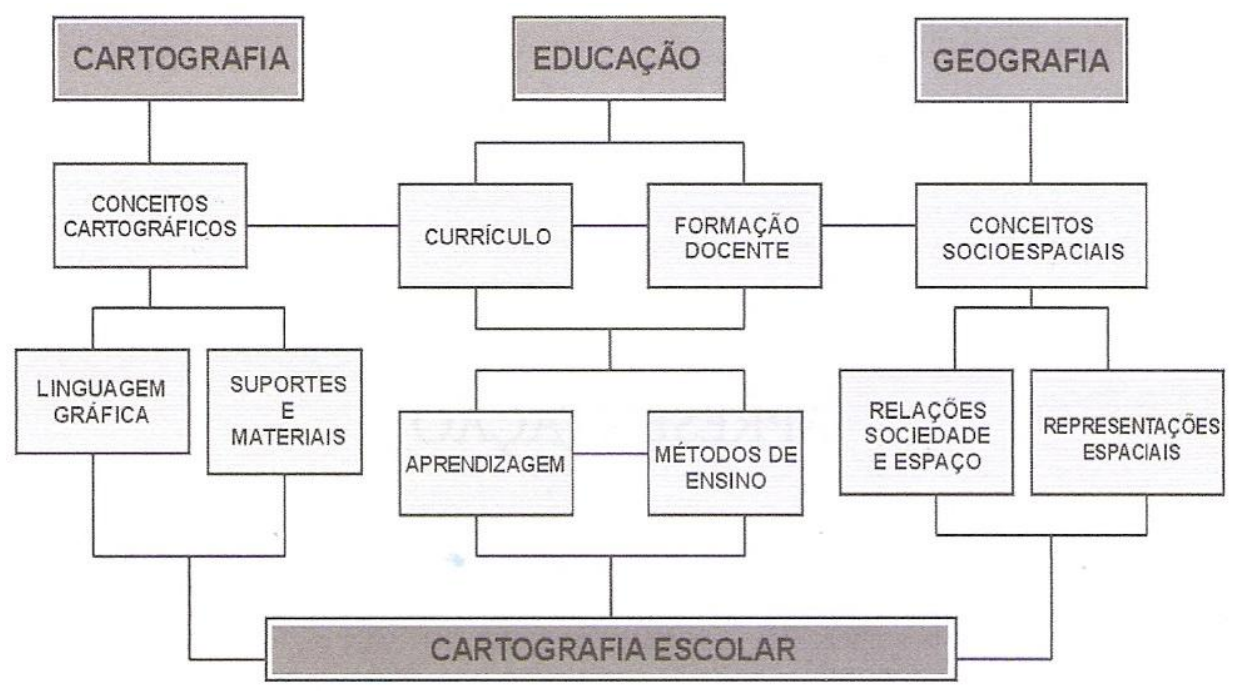

Figura 3 - Estruturação da Pesquisa em Cartografia Escolar Fonte: Almeida (2007: 10).

De acordo com Almeida (2010), (FIGURA 3), tais estudos envolveriam uma 
discussão complexa - que perpassaria os conceitos cartográficos no âmbito da Educação - quando aborda a temática do currículo e da formação docente, sendo ainda permeada pelas concepções socioespaciais da Geografia.

Seemann (2009: 2), ao também discutir a Cartografia Escolar, entende, entretanto que "a figura não deixa claro como se constitui a conexão entre as duas bases laterais, a cartografia e a geografia". O autor elabora então, a partir do fluxograma de Almeida (2007), uma estrutura circular (FIGURA 4).

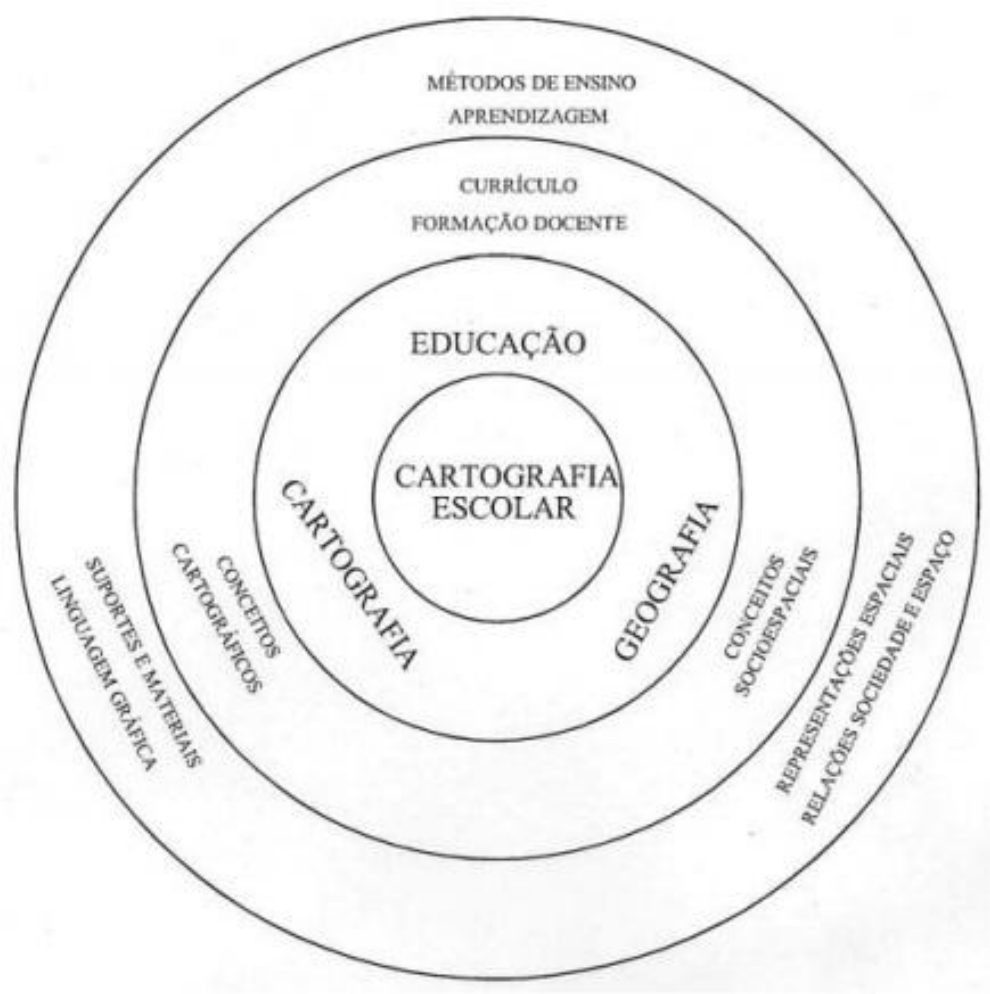

Figura 4 - A tríade da Cartografia Escolar

Fonte: Seemann (2009: 2).

A crítica de Seemann (2009: 2) parte da consideração de que o papel das práticas socioculturais merece ser redimensionado, pois "a educação se alimenta e se retroalimenta dos conceitos derivados da cartografia e da Geografia como também das práticas socioculturais realizadas na nossa sociedade". O autor propõe assim uma ressignificação, ou uma retomada da dimensão cultural da educação cartográfica e também da formação de professores. Apesar de a proposta dar relevo às relações socioculturais, Seeman (2009) afirma que o esquema por ele proposto, ainda não dá conta 
dessa tarefa, estando as relações culturais timidamente representadas no esquema pelo termo "Relações sociedade e espaço".

Como consequência de uma área de estudo que está em pleno desenvolvimento, Almeida (2011) amplia suas concepções ao passar a considerar que o "contexto social e cultural" é uma dimensão maior, na qual se dão as relações entre os conhecimentos das Ciências Humanas relacionadas com a Educação, das Ciências da Linguagem e das Ciências de referência, fornecendo, assim, fundamentos para uma Cartografia Escolar no contexto do ensino de Geografia, conforme a Figura 5.

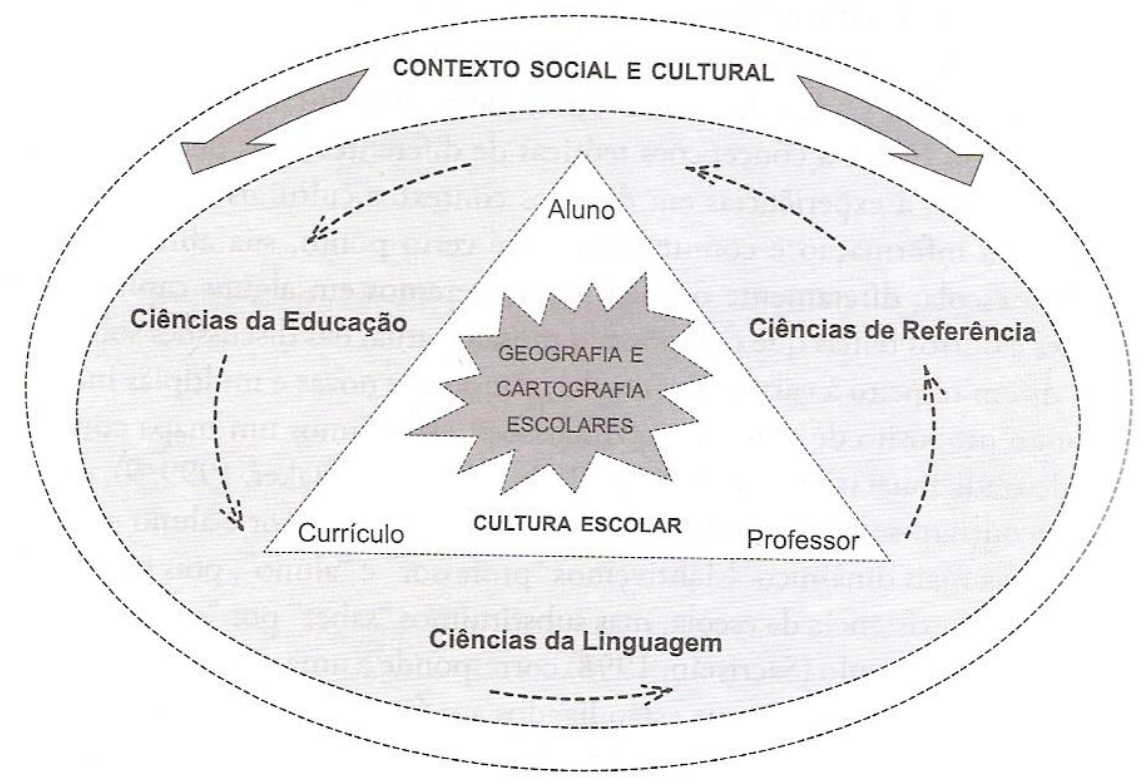

Figura 5 - A Cartografia Escolar Fonte: Almeida (2011: 8).

As considerações de Almeida $(2007,2011)$ e de Seemann (2009) indicam que qualquer investigação na área da Cartografia e da formação de professores de Geografia deve ter por base os fundamentos advindos da Educação, da Geografia e da Cartografia. Dessa forma, o referencial teórico do presente trabalho está ancorado em discussões com interseções nessas três grandes áreas: a Educação, a Geografia e a Cartografia.

Pressupomos que a Cartografia está presente nos currículos das licenciaturas, porém, não articulada de forma que possa ser apreendida pelos futuros professores como uma metodologia para a construção do conhecimento 
geográfico. Por isso a defesa da tese: a potencialidade da Cartografia na construção do raciocínio espacial impõe repensar a maneira como os conhecimentos cartográficos são construídos ao longo do processo de formação inicial dos professores de Geografia.

Para fundamentar as discussões aqui propostas, bem como a afirmação da tese apresentada, elaboramos um panorama da Cartografia que contempla diversos momentos históricos da sociedade humana como subsídio para entender a evolução metodológica dessa ciência. As reflexões buscam caminhar no sentido de melhor entendermos como a Cartografia se apresenta na formação de professores, e mostrar que há necessidade de repensar seu ensino na formação acadêmica, sobretudo na formação de professores de Geografia.

\subsection{Cartografia}

Pode-se pensar que o primeiro contato com a Cartografia se dá por meio do contato com os mapas. Ao considerarmos que a Cartografia nasce da necessidade humana de conhecer e de se reconhecer no espaço, podemos afirmar que, na mais tenra idade, o ser humano explora o espaço, de certa forma, cartografando-o, pois "o ser humano dispõe, muito precocemente, de certas competências no domínio espacial, que se manifestam quando situações favoráveis ocorrem" (ALMEIDA, 2001: 35).

As noções de orientação são básicas para o desenvolvimento do ser humano, pois, desde cedo, as crianças começam a desenvolver noções espaciais que propiciam o domínio do seu corpo e, sucessivamente, vão possibilitar o domínio dos espaços externos a ele.

O corpo ${ }^{2}$, para a criança, é o primeiro referencial espacial, a partir do qual se estrutura o conhecimento do espaço exterior a ela e, como consequência, de outros conhecimentos, uma vez que o conhecimento constrói-se na interação

\footnotetext{
${ }^{2}$ Diversos autores apontam que, antes de aprender os conteúdos ministrados pela escola, o corpo deve estar com todos os elementos psicomotores estruturados - esquema corporal, lateralidade, lateralização, organização espacial, organização temporal, coordenação e equilíbrio. As primeiras atividades escolares devem ser aquelas que propiciem 0 desenvolvimento de conceitos e de noções espaciais e temporais (ALMEIDA; PASSINI, 1994).
} 
do sujeito com o meio, dada a relação desse com estruturas existentes. Isso quer dizer que há estágios hierárquicos (sensório-motor, pré-operatório, operatório-concreto, operatório-formal) que se iniciam e continuam do nascimento à adolescência, fase em que se consolidam.

É dessa forma que podemos dizer que a base para a aprendizagem espacial infantil situa-se no próprio corpo. Podemos considerar que, se o professor conhece, reconhece e entende esses estágios, também reconheça e promova a descoberta e a construção do conhecimento e estimule a capacidade de análise, de crítica e de autonomia do aluno.

A descoberta e a construção do conhecimento permitem ao homem a possibilidade de reconhecer num objeto, fato ou situação, representados pelo que Garanderie (1981 apud LESANN, 2009: 26) chama de imagem mental. Esse ato de apreensão "não é exclusivo da Geografia", afirma Lesann, e está presente na "aquisição de qualquer conhecimento da vida cotidiana e escolar".

Conhecendo ou desenvolvendo conceitos e noções espaciais essenciais a todo ser humano, a escola integra um importante momento, mas não o único, em que se dá a iniciação aos mapas. Além da função de representar objetos, elementos, fenômenos e ambientes físicos e socioeconômicos, bem como a sua utilização, são atribuídas diversas funções aos mapas. Um exemplo disso pode ser verificado no texto "Os mapas", em que o filósofo Rubem Alves tece com ternura e sutileza peculiares algumas reflexões sobre uma obra de Veermer, pintor holandês que viveu entre 1632 e 1675, numa época em que os mapas tinham tanta popularidade quanto as figuras artísticas ${ }^{3}$. Alves faz referência aos mapas como uma espécie de ponte afetiva, ao escrever:

Assim são meus mapas. Olho para vastos espaços. Identifico rios, montanhas, mares, cidades. Não me dizem coisa alguma. Não me produzem nenhum riso. Mas há uns poucos lugares que brilham como estrelas. São lugares onde moram pessoas que eu amo. Ou lugares onde eu fui feliz, vi a beleza, experimentei o amor. Cada um tem um mapa que é só seu.

\footnotetext{
${ }^{3}$ Não consideramos Cartografia como Arte, pois embora o produto cartográfico possa dar a impressão de uma composição de pontos, linhas, áreas e todas as variáveis visuais, e pareça uma obra de arte, não é arte. Produtos cartográficos e produtos artísticos compreendem estruturas de linguagem diferentes.
} 
Imagino que, terminada a leitura da carta, a mulher voltou-se para o mapa e se pôs a sorrir enquanto suas mãos iam deslizando pelos mares, continentes, cidades... Alguém que a visse nesse estado de êxtase concluiria que ela havia enlouquecido. É compreensível: somente os amantes sabem que os mapas facilmente se transformam em corpos. Basta, para isso, que a despedida aconteça [...] (ALVES, 1996:125).

Ao contemplar a tela, Alves distingue no mapa diferentes lugares e espaços que não lhe dizem nada e espaços extremamente significativos classificados como lugares "onde foi feliz".

Outra obra de Vermeer foi objeto de reflexão em um artigo de Seemann (2009) intitulado "Arte, conhecimento geográfico e leitura de imagens: O geógrafo, de Vermeer". Ao discutir os elementos da dimensão espacial na obra de Vermeer, o Seemann considera que essa "não é apenas um objeto perfeito para uma leitura geográfica de imagens, mas também uma fonte quase inesgotável para discutir o passado, o presente e o futuro da Geografia".

Esses dois textos permitem-nos inferir que as apropriações que são feitas mostram que a Cartografia possui uma potencialidade muito além de simplesmente representar lugares. A despeito das diversas apropriações que se fazem da Cartografia, ao defender a tese de um necessário repensar a maneira como os conhecimentos cartográficos são construídos ao longo do processo de formação acadêmica dos professores de Geografia, é preciso entender as limitações claras da Cartografia vista como Arte e do que seria a linguagem da representação gráfica.

Direcionados no sentido de entender a linguagem da representação gráfica da Cartografia e sua potencialidade no Ensino Fundamental e Médio e como forma de esclarecer os pressupostos teóricos que orientam a tese, foi realizado um detalhamento teórico da Cartografia. Partimos de suas definições mais tradicionais ${ }^{4}$ até as diversas possibilidades de expressão e de sua apropriação

\footnotetext{
${ }^{4}$ Importante ressaltar que, quando optamos pelo termo "tradicionais" não estamos, de forma alguma, considerando os conceitos e temas da Cartografia básica que se aprendem e se ensinam como conhecimento ultrapassado e desnecessário. Ao contrário, queremos ressaltar a importância desse conhecimento como necessário e básico para se entender e avançar na compreensão da possibilidade de novas e interessantes métricas como se tem visto na atualidade (FONSECA, 2004).
} 
por meio de uma linguagem específica: a linguagem da representação gráfica da Cartografia.

\subsection{Evolução metodológica da Cartografia}

A aptidão para fazer mapas parece ser uma habilidade inata à humanidade desde os primórdios até os dias atuais. Autores como Harley (1991: 5) afirmam "que os mapas sempre existiram ou, pelo menos, o desejo de balizar o espaço sempre esteve presente na mente humana”. Por sua vez, Raisz (1969) considera a Cartografia a mais antiga forma de expressão realizada pela necessidade de reconhecer e dominar o território. A identificação da presença dessa linguagem ao longo da história das sociedades humanas constitui uma tarefa extremamente complexa ${ }^{5}$.

$\mathrm{Na}$ tentativa de refazer um percurso histórico da Cartografia, iniciamos por considerar o fato de os mapas estarem entre as mais antigas formas de comunicação humana (HARLEY, 1991: 5) e de que há poucas sociedades que não realizaram seus mapeamentos.

Em certo momento de sua evolução mental e cultural, tornou-se vantajoso para o homem estruturar a informação sobre os aspectos espaciais de seu mundo e comunicá-los aos outros (LEWIS, 1991: 50). Tais informações não poderiam ser transmitidas pelos sistemas de comunicação existentes como a fala e a música, o gesto ou a dança; desenvolveram-se, então, formas gráficas de comunicação.

A partir de então, é possível perceber que diversos exemplos de mapas de povos primitivos tinham, entre outros objetivos, a função de subsidiar as atividades de caça e de guerra. Entre esses exemplos encontram-se as cartas marítimas dos nativos das Ilhas Marshall, que mostravam que a maneira de representar dos povos primitivos é muito mais complexa do que as cartas modernas (tais mapas não eram riscados em suportes e sim montados como estruturas); mapas dos esquimós, com detalhes cartográficos, que coincidem

\footnotetext{
${ }^{5}$ Vejam-se as novas concepções de mapa, advindas dos trabalhos de Harley e Woodward, que nos instigam a considerar novas vertentes e outras vias que a Cartografia trilhou, e as perspectivas desses caminhos na formação do professor.
} 
de modo surpreendente com as melhores cartas hidrográficas atuais da região, e os mapas decorativos dos astecas, que representavam os feitos históricos (CASTRO, 2012; RAISZ, 1969).

Presentes em praticamente todos os povos, os mapas podem ser identificados em diferentes períodos históricos e com funções específicas (CASTRO, 2012). $\mathrm{Na}$ Idade Antiga, aproximadamente de 600 a. C. a 300 d. C., os babilônios manifestavam sua Cartografia na marcação da propriedade da terra cultivável.

Também com esse objetivo, aos egípcios atribui-se a invenção de um método de medir os campos, denominada pelos gregos como agrimensura. Tal medição advinha da necessidade prática de conhecer suas terras, a fim de determinar as alterações ocasionadas pela inundação anual do Rio Nilo (OLIVEIRA, 1993).

Concomitantemente, isolados do mundo ocidental, os chineses desenvolveram sua cartografia marcada por inúmeras engenhosidades, entre elas a invenção da bússola ${ }^{6}$. O progresso dos chineses foi alcançado com total independência do ocidente, visto que a China já havia sido mapeada com detalhes antes de qualquer europeu chegar lá (RAISZ,1969).

Os gregos, que aprenderam muito com os egípcios, aperfeiçoaram e aplicaram os conhecimentos cartográficos. A influência grega foi responsável por uma grande mudança na Cartografia, marcada pelo desenvolvimento dos conceitos geométricos pelos pensadores gregos. A partir de então, foi possível determinar a forma e o tamanho da Terra, bem como a localização relativa dos elementos na superfície (RAISZ, 1969).

A Cartografia grega trazia implícita a ideia da esfericidade da Terra. Anaximandro, por exemplo, elaborou uma representação que trazia a Grécia como centro do mundo. Hecateus, por volta de 500 a. C., teria elaborado a representação semelhante a um disco, ao redor do qual corriam as águas dos

\footnotetext{
${ }^{6}$ Harley e Woodward (1984) dedicam 6 capítulos no segundo volume da obra THE HISTORY OF CARTOGRAPHY para discutir a Cartografia na China, os Mapas chineses na cultura política, a Cartografia chinesa nas artes, a Cartografia tradicional chinesa e o mito da ocidentalização, o pensamento cosmográfico chinês, além de comentar os fundamentos para o "Futuro da História da Cartografia chinesa".
} 
oceanos. Aristóteles (350 a. C.), por sua vez, formulou argumentos para provar a esfericidade da Terra. Em sua obra Metaphysica aparece pela primeira vez a palavra Geodésia (OLIVEIRA, 1993). Já a Erastóstenes de Cirene (276-196 a. C.) atribui-se o cálculo da circunferência terrestre.

Entre as principais contribuições gregas para a Cartografia, consta que o grego Claudio Ptolomeu (96-168 d. C.), cuja obra marca o apogeu da Cartografia e seu ponto culminante no mundo antigo, refutou a ideia de que as terras emersas formariam uma ilha. Aliás, Ptolomeu foi o autor do primeiro Atlas Universal, ao qual se atribui a disseminação do uso das coordenadas geográficas e de projeções que só seriam substituídas 14 séculos depois pelo trabalho de Mercator.

Por sua vez, é dos romanos a elaboração da Orbis Terrarum, mapa que tinha o império como centro e mostrava detalhes de todas as rotas do Império Romano entre outras informações que eram utilizados para fins claramente políticos e administrativos.

As invasões bárbaras marcaram o início da Idade Média e também a interrupção da Cartografia científica clássica no mundo ocidental, juntamente com uma regressão no âmbito da Filosofia e da Cultura. Historicamente compreendida entre a queda do Império Romano (476 d. C.) e a tomada de Constantinopla (1453 d. C.), a Idade Média tem como ícone cartográfico o mapa $T$ no $O$, uma representação simbólica de caráter predominantemente religioso. Esse período marca o declínio dos conhecimentos em Cartografia, como aconteceu com grande das ciências.

Conforme Oliveira (1993:19),

[...] todas as conquistas científicas, no campo da astronomia e da matemática, foram postas de lado, em prol de conceitos puramente religiosos, sobretudo no período medieval mais obscuro.

O fim da Idade Média é marcado pela retomada comercial e pelo renascimento urbano, processos que demandariam conhecimento e domínio das características dos territórios. 
$\mathrm{Na}$ Idade Moderna, que vai do século XV ao século XVIII, Robinson et al. (1995) intitularam como Globalismo as novas perspectivas que a Renascença conferiu à Cartografia, num período de conquista e de explorações europeias, marcadas pela rápida expansão do comércio pelo planeta. Com tais inovações, as viagens mediterrâneas e as navegações com apoio das "cartas portulano" tiraram a Cartografia da hibernação medieval.

Como aconteceu com outros ramos da Ciência, o período do Renascimento (1400 a 1700) marcou também o renascimento da Cartografia por três motivos: i) tradução da Geografia de Ptolomeu para o Latim, ii) invenção da imprensa e da gravação e iii) os grandes descobrimentos (CASTRO, 2012).

Ptolomeu concebia o universo como Aristóteles, e deixou obra célebre, que por séculos permaneceu como trabalho de referência. Para Ptolomeu, a Terra seria um planeta de forma esférica parado no centro, com os demais corpos celestes descrevendo movimentos circulares ao seu redor (VASCONCELLOS, 1993). Seu mapa revela a adoção das linhas coordenadas de latitude e de longitude com base na divisão do círculo de 360․ Tais conhecimentos foram fundamentais para a exploração de espaços além-mar, a partir da circunavegação.

Por seu turno, a invenção da imprensa "teve grande influência no progresso da Cartografia, porquanto possibilitou a fácil reprodução de mapas, barateando seu custo unitário e permitindo maior difusão" (MARTINELLI, 2013: 9). Além disso, é considerado marcante, e decorrente da invenção da imprensa, o estabelecimento da Cartografia como ofício (MARTINELLI, 2013).

Os grandes descobrimentos dos séculos $\mathrm{XV}$ e XVI impulsionaram a Cartografia, que auxiliava o alcance dos objetivos daqueles: descobrir uma nova rota marítima para as Índias e encontrar novas terras. A necessidade de garantir a segurança dos viajantes e a representação das novas descobertas causou uma busca crescente por mapas que, conforme Martinelli (2013: 9), 
produção. Os mapas confirmaram-se como armas do capitalismo, promovendo a política colonial.

A expansão marítima e a descoberta do Novo Mundo inauguraram novos rumos para as representações cartográficas. Essas representações buscavam o estabelecimento da exatidão, através do registro dos lugares visitados respondendo às questões: o quê? e onde? Observa-se que,

À medida que a cartografia foi fazendo progressos, vão-se representando, com rigor, os diversos continentes, dando precisão às linhas de costa e introduzindo a noção de escala no desenho. Até o volume de informação sobre cada região se ampliará (BARATA, 1997: 25).

Martinelli (1998) ressalta que, por volta do século XVIII, a Cartografia obteve um grande avanço com a instituição de academias científicas, que deram início à ciência Cartográfica Moderna. Nesse período, os holandeses destacaram-se por suas habilidades na navegação e na colonização, ambiente que favoreceu o florescimento de grandes cartógrafos, como o holandês Gerard Mercator, nome considerado marco na Cartografia Moderna. As grandes navegações forneciam informações sobre áreas remotas e também exigiam mapas mais precisos (ALMEIDA, 2001; CASTRO, 2012).

Não podemos deixar de destacar que é na Cartografia temática que os mapas se abrem para outras finalidades, além de apenas posicionar lugares. Martinelli (1999) explica que, com a Cartografia temática, os mapas vão se desprendendo pouco a pouco da herança topográfica, e passam a representar o conjunto das relações entre os objetos.

A Cartografia náutica, por exigir uma linguagem distinta da topográfica, incluise na transição entre a Cartografia topográfica e a (MARTINELLI, 1999).

Dessa forma,

Certos fenômenos úteis à navegação, que não se inscrevem materialmente e geometricamente sobre a superfície da Terra, como o magnetismo terrestre, os ventos $\mathrm{e}$ as correntes marítimas, contribuíram para o avanço no campo da lucubração dos mapas temáticos (MARTINELLI, 1999: 25). 
No contexto das diversas transformações ocorridas na Idade Moderna, as grandes navegações, as muitas descobertas e conquistas territoriais causaram grandes transformações e revolução na forma como o mundo era concebido e visualizado.

Assim,

A progressiva especialização e diversificação das realizações da cartografia científica, operadas desde os séculos XVII e XVIII e cristalizadas no século XIX, em atendimento às crescentes necessidades de aplicação confirmadas com 0 florescimento e a sistematização dos diferentes ramos de estudos constituídos com a divisão do trabalho científico, no fim do século XVIII e início do século XXI, culminaram na definição de outro tipo de cartografia: a Cartografia Temática (MARTINELLI, 2013: 27).

A Cartografia, como as demais ciências, também se viu impactada pelos ideais do lluminismo, movimento contrário ao Absolutismo, que buscava uma explicação científica para todo fenômeno percebido. Entre os principais iluministas destacam-se René Descartes e Isaac Newton, tidos como principais pensadores que deram maior impulso a essa nova concepção de mundo e das ciências, marcando também a Cartografia.

$\mathrm{Na}$ Idade Contemporânea, que vai do século XVIII até os dias atuais, a humanidade vivencia as consequências do avanço e da consolidação do regime capitalista, principalmente no Ocidente. Disputas entre países, por territórios, por matérias-primas ou por populações, que pudessem servir como mercados consumidores marcam esse período histórico, ultimamente caracterizado por uma euforia tecnológica propagada pela Revolução Industrial.

A tecnologia incidiu sobre a Cartografia, determinando diversas contribuições como as tecnologias do Geoprocessamento, e fez com que aquela se popularizasse nas mídias, cujos produtos são disponibilizados em todos os tipos de dispositivos eletrônicos, inclusive nos populares smartphones ${ }^{7}$.

\footnotetext{
${ }^{7}$ NUNES. José Jesús Reyes. Smartphone-based school atlases? In: Cartographica, 48:2, 2013, p. $126-133$.
} 
Essas reflexões sobre a história da Cartografia mostram que as mudanças tecnológicas e a evolução por que passou a humanidade contribuíram para 0 desenvolvimento dessa ciência (QUEIROZ FILHO; RODRIGUES, 2007).

Não se deve fazer, contudo, uma interpretação do percurso da Cartografia sob um ponto de vista linear. Há uma complexidade muito maior em sua evolução. No entanto é, muitas vezes, sob o signo da linearidade e da evolução tecnológica que se caracteriza a versão apresentada aos ingressantes na Cartografia na Educação Básica ou no Ensino Superior.

A história da Cartografia, na perspectiva da linearidade e da evolução técnica, é contada como uma sucessão de substituições por meio das quais os mapas vão se alternando, conforme a superioridade tecnológica do novo, na busca pela acurácia (GIRARDI, 2012). A busca da exatidão e da precisão deslocou seu foco, que deveria centrar-se na metodologia e suas contribuições, para uma leitura da realidade espacial.

Por uma ausência de crítica à forma como se apresentam os fatos, instaura-se a noção equivocada de que a Cartografia seria, pura e simplesmente, uma técnica objetiva que trouxe grandes avanços para toda a humanidade por meio dos progressos alcançados a partir de suas imagens científicas.

É importante estar atento ao descrever o percurso da Cartografia. Em seu desenvolvimento, a Cartografia Moderna acompanhou os processos de automação, o estudo avançado das áreas temáticas e o uso cada vez mais intenso do mapa como recurso de pesquisa científica. Tais atribuições conferiram legitimidade e certa objetividade a seus propósitos. Contudo, em Mapa, saber e poder, Harley (2009) apresenta outra perspectiva sobre a história da Cartografia, ao criticar a inexistência de questionamento do papel dos mapas "como imagens ligadas a contextos históricos precisos".

Ao tratar as perspectivas teóricas, Harley considera os mapas como integrantes de uma família mais abrangente das imagens, a daquelas carregadas de juízo de valor. Nesse sentido, a simples localização, ou a escolha dos elementos de representação, traz implícita uma visão de mundo, inserida num determinado contexto e sujeita a escolhas carregadas de 
subjetividade por parte de quem os elabora. Harley propõe outras possibilidades de entendimento do mapa na sociedade, e afirma que a Cartografia pode ser uma forma de conhecimento e uma forma de poder. Ao longo dos diversos períodos históricos, a Cartografia foi um conhecimento ligado aos detentores do poder na sociedade e nas relações em que a necessidade de conhecimento do espaço se impunha.

Um exemplo curioso sobre o poder dos mapas é apontado por Furtado (2012: 65):

\begin{abstract}
Assim, o rei teria à disposição mapas nos quais poderia brincar com fronteiras, posicionando-as a seu bel-prazer, configurando diferentes conformações dos estados, pois o que o mesmo queria era fazer daqueles nossos projetos sobre a carta; [...] como nos costumávamos discorrer jogando xadrez. Apresentava outra utilidade às cartas. Como em um tabuleiro, é o leitor/jogador, e não o produtor do mapa, que dispõe e muda as linhas que marcam as fronteiras dos países. Num contexto de intensas rivalidades entre as nações, como foi o século $\mathrm{XVIII}$, em que as guerras, e depois os tratados de paz, provocaram intensa mobilidade dos territórios, um mapa sem as fronteiras demarcadas de antemão permitia que seu usuário simulasse os possíveis resultados dos conflitos e das negociações em curso.
\end{abstract}

Ao abordar o papel dos mapas, a autora comenta que mapas sem linhas divisórias eram requeridos pelos poderosos (nobres, imperadores, marqueses) no século XVIII. Daí, talvez, tenham nascido os "mapas mudos" para exercícios de Cartografia.

$\mathrm{Na}$ atualidade, a Cartografia está definitivamente presente no dia-a-dia das pessoas, por meio dos mapas que estão em toda parte: nas páginas dos jornais, nas revistas impressas, na internet, nos jogos (físicos e virtuais), nos aplicativos nos celulares, em GPS (Global Positioning System) nos carros, nos jornais televisivos diários, em propagandas impressas como as de imobiliárias, em revistas, nas artes, nos livros didáticos impressos, entre outros.

Fonseca (2004: 113) afirma que "a Cartografia se populariza nas mídias muito em função das possibilidades de rapidez para a exposição visual que a cartografia assistida por computador trouxe". A popularização da Cartografia não veio acompanhada de uma leitura crítica sobre os propósitos de tais 
produtos. Nos cursos de Licenciatura, seus produtos são considerados legítimos e objetivos em seus propósitos. Alguns autores como Girardi (2001: 29), vislumbram uma perspectiva que vai mais além, propondo uma desmistificação do mapa, em que haveria de se empreender

[...] a descoberta de procedimentos de desmistificação da imagem cartográfica, de reafirmação do mapa, antes de mais nada como um discurso, menos como técnica, ainda que essa seja um de seus fortes apelos. Instrumentalizar os graduandos em Geografia na leitura do mapa como representação de formas de ver o mundo, social, cultural e historicamente construídas, ou seja, capacitá-los a ler criticamente mapas como o fazem com textos, pode vir a ser a via de reaproximação desses dois campos do conhecimento, valorizando a imagem na construção da ciência geográfica.

Assim como Girardi (2001), entendemos que a desmistificação da imagem cartográfica demanda um novo modo pensar a formação de professores de Geografia, tendo em vista a necessidade de outros pressupostos teóricos.

\subsection{Refletindo sobre algumas definições de Cartografia}

A Cartografia, aparentemente tão acessível, experimentou ao longo de sua história um processo de redimensionamento de sua esfera de atuação, bem como de seus objetivos. Tal processo pode ser, de certa forma, acompanhado nas diversas definições que se atribuiu à Cartografia ao longo do tempo, muitas das quais com o objetivo de especificar suas teorias e seus métodos, ou mesmo representar uma busca de sistematização rumo à estruturação da Cartografia como ciência, o que é um evento relativamente novo (KANAKUBO, 1995).

Uma breve leitura das inúmeras definições de Cartografia $^{8}$ mostra diversos momentos, cada um com suas contribuições históricas ao processo de estruturação da Cartografia como ciência ao longo do tempo. A abordagem das diferentes definições também permite conhecer a contribuição de autores que são importantes personagens na estruturação teórica da Cartografia em nível nacional e internacional. Esse movimento cooperativo em torno da pesquisa

\footnotetext{
${ }^{8}$ Informações sobre as definições têm como fonte notas de aula do Prof. Marcello Martinelli, na disciplina Representações gráficas da Geografia: teoria e prática, ministrada no segundo semestre de 2011.
} 
em Cartografia, inclusive, acontece atualmente no campo da Cartografia Escolar.

Conforme Harley (2009), os mapas funcionam como instrumentos de poder, de controle do espaço pelo Estado, que tem exclusivo domínio sobre os instrumentos de coleta de informação. No Brasil, foram as escolas militares detentoras do conhecimento cartográfico por um extenso período. Por volta de 1930, as escolas militares consideravam a Cartografia como a ciência que teria por objeto o estabelecimento e o emprego das cartas, compreendendo a Geodésia, a Topografia e a Cartografia, como o produto final, a reprodução industrial sobre o papel da minuta do topógrafo. Dessa forma, o produto cartográfico representava com fidelidade e objetividade o conhecimento do terreno.

Por volta de 1949, segundo Oliveira (1993: 13), o relatório da comissão de especialista das Nações Unidas definiu a Cartografia como "a ciência que se ocupa da elaboração de mapas de toda espécie" e abrangeria todas as fases dos trabalhos, desde os primeiros levantamentos até a impressão final dos mapas.

Essa conceituação foi considerada muito ampla, pois apontava que a Cartografia compreendia uma tarefa complicada já que, nessa definição, estariam incluídas tarefas do campo da Cartografia, da Astronomia, da Geodésia, da Topografia, da Fotogrametria e da oficina de offset (OLIVEIRA, 1993). Por ser considerada ambiciosa e demasiadamente abrangente, foi muito criticada por cartógrafos de todos os países. Gerou-se um esforço conjunto entre os estudiosos nesse campo sobre a definição de Cartografia apresentada no relatório. O contexto histórico nos permite refletir sobre tal empenho, também observado por KRAAK e ORMELING (2010), que consideram que o significado do termo Cartografia mudou substancialmente desde os anos 1960.

Por volta de 1949, os velhos sistemas coloniais ruíram: a Síria e o Líbano tornaram-se independentes em 1945, a Índia e o Paquistão em 1947, Birmânia e Ceilão, Palestina e as Índias Orientais holandesas (Indonésia), em 1948. O império japonês havia desaparecido. Enquanto na África Central e Setentrional 
a situação estava calma, uma resistência comunista no Sudeste Asiático desconsertava a descolonização pacífica e marcaria toda a história dos Estados Unidos para sempre.

Conforme Hobsbawm (1995: 215):

[...] os franceses, apoiados pelos britânicos e depois pelos EUA, realizaram uma desesperada ação para reconquistar e manter o país (Indochina francesa, atuais Vietnã, Camboja e Laos) contra a revolução vitoriosa. Foram derrotados e obrigados a se retirar em 1954, mas os Estados Unidos impediram a unificação do país e mantiveram um regime satélite na parte sul do Vietnã dividido. Depois que este, por sua vez, pareceu à beira do colapso, os Estados Unidos travaram dez anos de uma grande guerra, até serem por fim derrotados e obrigados a retirar-se em 1975, depois de lançar sobre o infeliz país um volume explosivo maior do que o empregado em toda a Segunda Guerra Mundial.

O mundo pós-guerra impunha a necessidade de um programa racional de mapeamento, daí o empenho em torno da Cartografia e sua definição.

Oliveira (1993: 13) explica que

[...] as discussões em Lake Success (local da conferência da Organização das Nações Unidas - ONU de 1949) quase sempre em inglês, giravam em torno do problema mundial do mapping, tal qual se apresentava após a II Guerra Mundial. Ora, mapping, diga-se de passagem, pode igualmente ter 0 sentido de cartografia, representava, naquela oportunidade, um problema a ser resolvido no mundo de após guerra.

Nota-se que as definições posteriores, pelas suas datas, demonstram uma tentativa de respostas às demandas em torno da Cartografia. Em 1954, K. A. Salichtchev ${ }^{9}$, eminente geógrafo soviético, definia a Cartografia como a ciência dos mapas geográficos com um método especial de representação da realidade, incluindo nas suas metas tanto o estudo completo de mapas geográficos, como a formulação de métodos e processos de sua confecção e uso. O empenho da cartografia soviética adivinha da consideração de que tal conhecimento era necessário para a implementação dos planos econômicos do

\footnotetext{
9 Eleito como Honorary Fellow, membro honorário, na VIII Associação Cartográfica Internacional em Moscou, em agosto de 1976, em reconhecimento a suas notáveis contribuições educacionais e acadêmicas, à sua experiência no campo da elaboração de atlas e seu serviço à causa da cartografia, em nível nacional e internacional.
} 
estado leninista. Havia a necessidade de levantamento topográfico e de exploração geográfica do país, posto que em tal época, apenas $10 \%$ do país estavam topograficamente mapeados (ORMELING, 1978).

Nas décadas de 1960 e 1970, observava-se o advento dos satélites e dos computadores e, com isso, uma nova perspectiva para a Cartografia, trazida pelos estudos sobre comunicação cartográfica (VASCONCELLOS, 1993).

Em 1964, Rimbert define a Cartografia como a transcrição gráfica dos fenômenos geográficos (tem por fim a concepção, a preparação, a redação e a realização de todos os tipos de planos e cartas; envolve particularmente o estudo da expressão gráfica dos fenômenos a serem representados).

A Associação Cartográfica Internacional $(\mathrm{ACl})^{10}$ apresentou diferentes conceituações para a Cartografia. De acordo com a Associação Cartográfica Internacional, a definição datada de 1964, citada por Joly (1990: 8), a Cartografia compreenderia

[...] o conjunto dos estudos e das operações científicas, artísticas e técnicas que intervêm a partir dos resultados das observações diretas ou da exploração de uma documentação, em vista da elaboração de uma documentação, em vista da elaboração e do estabelecimento de mapas, planos e outros modos de expressão, assim como de sua utilização.

Kolacny, em 1968, ao apresentar sua tese Cartographic information - a fundamental concept and term in modern cartography, que exibia um modelo de diagrama preocupado com a comunicação cartográfica, definiu a Cartografia como teoria, técnica e prática de duas esferas de interesse: a criação e o uso dos mapas (cf. KANAKUBO, 1995). Kolacny foi um dos pioneiros a destacar a importância da comunicação cartográfica. Começava a aparecer uma preocupação com o uso dos mapas, que posteriormente se configurará em um modelo de transmissão da informação cartográfica, que teve importantes desdobramentos no entendimento das relações entre o usuário do mapa, a mensagem transmitida e a eficiência do mapa como meio de comunicação.

10 Fundada em 1959, como uma organização que reunia diversas associações científicas relacionadas à Cartografia, da qual faziam parte os autores mencionados. 
Arnberger, da Áustria, declarou em sua obra, ser a Cartografia uma ciência formal, ou seja, que utilizaria a razão para fazer uma análise, como a Lógica e a Matemática. Em 1970, Arnberger definiu a Cartografia como a ciência da lógica, metodologia e técnica do design, confecção e interpretação dos mapas e outras formas cartográficas de expressão, as quais são capazes de reproduzir uma imagem espacialmente correta da realidade. Essa definição dá relevância à preocupação existente no interior da Cartografia que seria a de ser fidedigna à realidade representada. Esse seria o legado da Cartografia convencional ocidental, racional e científica.

Ratajski, da Polônia, profundamente interessado no processo de transmissão da informação cartográfica, definiu, em 1970, que a Cartografia é uma parte da atividade humana que abrange a criação e a utilização dos mapas, bem como de outros trabalhos cartográficos. Para Ratajski, a Cartografia está, e sempre esteve ligada à comunicação interpessoal. Nesse sentido, elaborou um modelo gráfico de comunicação cartográfica, aplicando a teoria matemática da informação de Shannon e Weaver $(1949)^{11}$ para construir sua teoria, interessado no esclarecimento dos efeitos de transmissão, e procurando explicar a perda da informação no trajeto comunicativo entre emissor e receptor, durante o qual podem comparecer interferências e ruídos para atrapalhar o entendimento da mensagem (Cf. KANAKUBO, 1995).

Em 1973, Salichtchev apresentou uma definição que, diferentemente da primeira focada mais na técnica e nos processos, estabeleceu a Cartografia como a ciência da retratação e do estudo da distribuição espacial dos fenômenos naturais e culturais, suas relações e suas mudanças ao longo do tempo, por meio das representações cartográficas - modelos-imagenssímbolos -, que reproduzem esse ou aquele aspecto da realidade de forma gráfica e generalizada. Note-se que a atenção, nessa definição, parece estar mais direcionada ao objeto da representação do que à forma de representar em si. Por ocasião dessas discussões (1973), a ACl conceituaria a Cartografia

\footnotetext{
${ }^{11}$ Shannon, Claude E. Weaver, Warren. The Matematical Theory of communication. University of llinnois Press, 1949.
} 
como "teoria, técnica e prática de duas esferas de interesse: a criação e uso dos mapas".

Em Cartographic communication links and a cartographic alphabet, K. A. Meine (Alemanha, 1974) manifestou "a necessidade de uma expansão no conhecimento do processo de comunicação cartográfica, da criação de um alfabeto para uma linguagem básica dos mapas e da aplicação semiológica para tal alfabeto" (Cf. KANAKUBO, 1995: 12). Em 1979, Meine definiu a Cartografia como a ciência e a técnica para discutir, desenvolver e ensinar métodos para representações cartográficas. Dessa forma, ela lidaria com problemas da comunicação de informação espacial sobre objetos, relações, desenvolvimentos, processos e sistemas, por meio de mapas e de cartas, utilizando figuras de visualização legíveis (MARTINELLI, 2011).

O americano J. L. Morrison, em 1979, por seu lado, definiu a Cartografia como a ciência da comunicação da informação entre indivíduos, pelo uso de mapas, solidário, portanto, à ideia "de que o papel do mapa era comunicar, e que o objetivo da cartografia era verificar e completar o processo de comunicação" (Cf. KANAKUBO, 1995).

Em 1989, por ocasião da Conferência de Budapeste, a $\mathrm{ACl}$ concluiu que a Cartografia deve ser entendida como

[...] a organização, apresentação, comunicação e utilização da geo-informação (sic) nas formas visual, digital ou táctil, que inclui todos os processos de preparação de dados no emprego e estudo de todo e qualquer tipo de mapa. Em síntese, a Cartografia se preocupa atualmente com o usuário do mapa, com a mensagem transmitida e com a eficiência do mapa como elemento transmissor de informação (CONFERENCIA DE BUDAPESTE).

Da década de 1990 em diante, perceberam-se grandes transformações nas bases teóricas e técnicas que culminaram numa ampliação da Cartografia com novas abordagens e novas perspectivas.

Assim, a Cartografia passa a referir-se a um campo definido da atividade humana em que a organização do espaço terrestre, ou não, é mostrada por 
meio de mapas, os quais resultam de uma série de operações. Em diversas definições, considera-se a Cartografia como ciência e como arte: "Transparece assim um conceito comum para a Cartografia: arte, método e técnica de representar a superfície da terra e seus fenômenos" (SOUZA; KATUTA, 2001).

Como ciência, a Cartografia

[...] requer desenvolvimento de conhecimentos específicos, aplicação sistemática de operações de campo e de laboratório, planejamento dessas operações, metodologia de trabalho, aplicação de técnicas e conhecimento de outras ciências, tudo com vistas à obtenção de um documento de caráter altamente técnico (DUARTE, 2006: 15).

A esse respeito, duas afirmações devem ser consideradas: a de Souza e Katuta (2001: 56), que destacam a capacidade de os documentos possibilitarem "reflexão, análise e interpretação da qualidade das informações cartografadas" e a de Duarte (2006: 15), que atribuem à Cartografia a função de arte:

[...] um mapa deve respeitar determinados aspectos estéticos, pois se trata de um documento que precisa ser agradável às vistas, razão pela qual necessita de uma boa disposição de seus elementos (traços, símbolos, cores, letreiro, margens, legenda, etc.).

Essas características são, para Souza e Katuta (2001), denominadas de qualidade plástica da representação, e referem-se também aos aspectos estéticos. Nesse sentido, Erwin Raisz foi um dos estudiosos que enfatizaram os aspectos científicos e artísticos dos mapas (Cf. KANAKUBO, 1995).

As inúmeras definições encontradas demonstram diversas concepções ao longo do desenvolvimento científico, cada uma delas refletindo um momento no processo de evolução metodológica da Cartografia como ciência.

Martinelli (2010), em texto sobre a Sistematização da Cartografia Temática considera as seguintes definições:

Cartografia é a ciência da representação e do estudo da distribuição espacial dos fenômenos naturais e sociais, suas relações e suas transformações ao longo do tempo, por meio 
de representações cartográficas - modelos icônicos - que reproduzem este ou aquele aspecto da realidade de forma gráfica e generalizada (SALICHTCHEV ${ }^{12}$, 1973 apud MARTINELLI, 2010: 196).

Organização, apresentação, comunicação e utilização da geoinformação nas formas visual, digital ou tátil que inclui todos os processos de preparação de dados, no emprego e estudo de todo e qualquer tipo de mapa (TAYLOR ${ }^{13}, 1994$ apud MARTINELLI, 2010: 197).

É ainda Martinelli (2010) que, em suas opções, assinala a intenção de "mostrar claramente que a cartografia não é apenas uma técnica, como hoje se enaltece, indiferentemente do conteúdo". Além disso, o autor entende que estão presentes nessas definições o caráter social e outras formas táteis. Essas definições, além de abrangentes, em relação aos estudos mais recentes em Cartografia, contemplam ainda uma dimensão crítica da produção cartográfica que, para alguns autores, sempre existiu e, para outros, está cada vez mais presente entre os estudiosos da área.

Ao analisarmos essas definições, podemos concluir que, além do incremento tecnológico, também houve uma transformação teórica. Alguns autores ampliam e redimensionam, em seus estudos, a definição de Cartografia.

Fonseca e Oliva (2013: 13), por exemplo, afirmam que

A cartografia restringia-se a uma ciência que estuda e realiza os mapas, esse sentido se expandiu e atualmente cartografia é, também, a teoria cognitiva e a teoria sobre as tecnologias que reduzem a complexidade do mundo real a uma representação gráfica.

Entendemos ser importante discutir os contextos em que as ciências se instituem, bem como seus conceitos e temas. Além de conhecer, no caso da Cartografia, talvez possa auxiliar no sentido de se desconstruir a noção tida como única e inequívoca da "cartografia baseada quase exclusivamente em conceitos e princípios que permitem uma medição de fenômenos em termos

\footnotetext{
${ }^{12}$ SALICHTCHEV, K. A. "Some reflections on the subject and method of cartography after the Sixth International Cartographic Conference", The Canadian Cartographer, 10 (2): 106 - 111, 1973.

13 TAYLOR, D. R. F. Perspectives on visualization and moderns cartography. In.: MACEACHREN, A. M.; TAYLOR, D. F. (Ed.). Visualization in modern cartography. London: Elsevier Science, 1994.
} 
numéricos (coordenadas, escala, distâncias etc.)" e contribuir para que a Cartografia também possa ser vista para além de "uma técnica, mas também como parte das nossas próprias práticas sociais" conforme, provoca Seemann (2009: 4).

A Cartografia seria uma pretensa representação da realidade física imediata do espaço. Essa poderia ser uma definição. Contudo, constata-se que definir torna-se tarefa deveras complicada, visto que a Cartografia vai muito além, por unir convergências teóricas do campo da representação, do discurso e do poder, conforme demonstra Dias (2011):

Espaço cartográfico, portanto, é a representação discursiva do
poder, expressada sobre suportes diversos, contendo
desenhos, figuras e linhas simbolizando posses e demarcações
imaginárias. Produzir espaços cartográficos faz parte da
capacidade técnica humana de representar territórios
imaginários, nações imaginárias, como uma amostragem de
poder, revestidos de intencionalidades e interesses bem
definidos (DIAS, 2011:6).

Essa complexidade envolvida na produção dos espaços cartográficos (DIAS, 2011), que também se aplica à Cartografia como os geógrafos a utilizam, amplia-se ainda mais quando dois fatores se verificam: o fato de a Cartografia ter sido incluída no campo das ciências da comunicação, e o advento do computador. O advento do computador contribuiu para uma mudança quantitativa e qualitativa da Cartografia, e influenciou todas as suas etapas, da coleta dos dados até o design e a reprodução de mapas (VASCONCELLOS, 1993).

Apesar de estar culturalmente associada à Geografia (MARTINELLI, 2010), a ciência cartográfica possui suas especificidades. Geografia e Cartografia constituem distintos campos do conhecimento com objetos de estudo e métodos igualmente particulares. Uma parte dos conhecimentos cartográficos serve como instrumento para representações gráficas em mapas e para as análises geográficas feitas a partir de mapas (SOUZA; KATUTA, 2001).

Por essa razão, Martinelli (2010) destaca a necessidade do "conhecimento da essência dos fenômenos que estão sendo representados" e do suporte das 
ciências que fazem uso deste estudo", ou seja, para se fazer uma Cartografia que sirva às representações em mapas e às análises geográficas, há de se considerar que a Geografia requer uma Cartografia específica, que tem sido denominada por alguns estudiosos de Cartografia Geográfica ou Cartografia para a Geografia.

De acordo com os objetivos desta pesquisa, que se insere no contexto da formação de professores, parece-nos interessante contemplar em nossas reflexões uma possibilidade de apreensão da produção em Cartografia, seus conceitos e temas bem como suas diversas áreas de estudo.

Sendo assim, com objetivos didáticos, procuramos entender a evolução da Cartografia enquanto campo de estudo. Consideremos o esquema de Castro (2012), que propõe, para efeito didático e prático, a divisão da Cartografia representada na Figura 6.

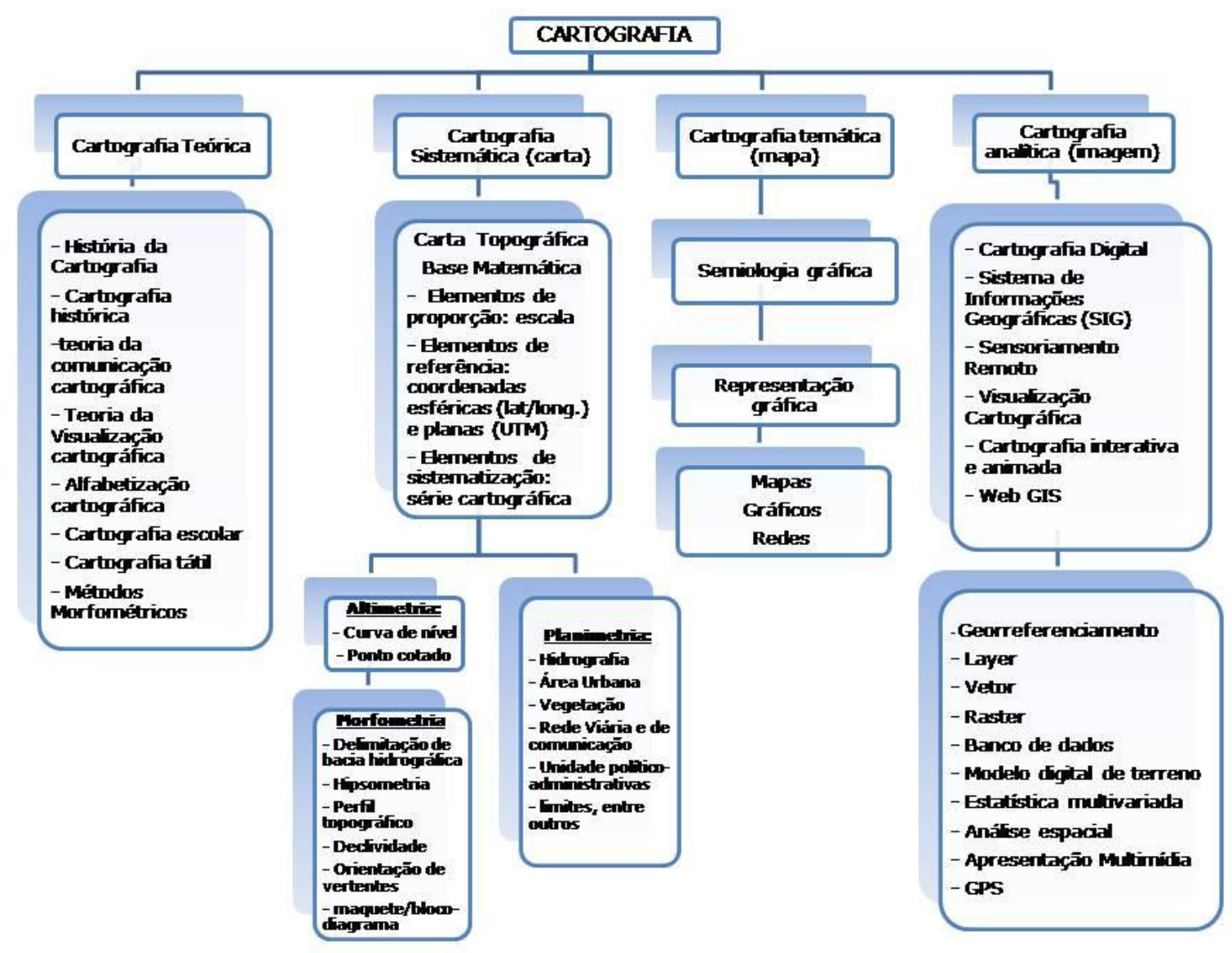

Figura 6 - Os campos de estudo da Cartografia.

Fonte: Castro, 2012, p.45. 
Analisando o esquema, é possível perceber que a Cartografia envolve conhecimentos específicos que servem a diversas outras áreas do conhecimento que se interessam pela informação espacial. Essa representação esquemática da Cartografia não permite perceber como se deu a evolução metodológica até se chegar ao que a Cartografia é, e estuda na atualidade $^{14}$.

Compreender o percurso de uma determinada ciência pode ser importante, quando se deseja discutir como tais conhecimentos se apresentam na formação dos professores. Ao se discutir a Cartografia, pode ser interessante um olhar sobre os paradigmas ${ }^{15}$ ou fundamentos predominantes nessa ciência.

\subsection{Correntes Teórico-metodológicas da Cartografia}

Uma das formas de entender a evolução metodológica de um ramo do conhecimento é a da demarcação das correntes teóricas ou fundamentos que orientaram a pesquisa e a produção de conhecimento em determinadas áreas e em determinado período histórico.

Nesse sentido, é necessário ressalvar, à maneira de Matias (1996), que, sob um determinado fundamento teórico, desenvolvem-se linhas de pensamento que ora se aproximam na defesa de alguns pontos, ora se distanciam em termos de entendimento ou de concepção de determinada temática:

[...] como ocorre em qualquer outro ramo do conhecimento humano, é uma tarefa difícil delimitar com exatidão cada uma das correntes teóricas que se apresentam ao debate da Cartografia, uma vez que, em muitos casos, tais grupos se apresentam como complementares ou com sobreposições significativas (MATIAS, 1996: 50).

\footnotetext{
${ }^{14}$ É preciso verificar cuidadosamente este esquema, visto que a Cartografia teórica não está corretamente definida. Outra observação necessária refere-se à Semiologia Gráfica. Conforme - esquema, ela aparece somente na Cartografia Temática, o que é uma concepção equivocada, visto que estaria em toda a Cartografia. Ainda na Cartografia Temática, questionase a vinculação de Gráficos e Redes à Cartografia Temática, visto que pertenceriam à área da Estatística Gráfica e da Matemática. Também é questionável o reducionismo conceitual relativo à Cartografia Analítica.

${ }^{15} \mathrm{Um}$ paradigma é um modelo ou um referencial aceito pelos especialistas de determinada área científica. Segundo Khun (1987), a ciência avança através de paradigmas que vão se substituindo conforme sua superação ou abandono. Um paradigma refere-se a um padrão estável de uma atividade científica em determinado momento.
} 
No caso da Cartografia e da Cartografia Temática, mais especificamente, um dos primeiros paradigmas ou modelos teóricos em seu processo de evolução seria o paradigma positivista.

O Positivismo, movimento epistemológico desenvolvido na Europa no século XIX, tinha como método científico o empirismo indutivo que, a partir de observações, classificações e comparações, buscava chegar a conclusões que serviriam de base para a elaboração de leis gerais. Essas leis destinavam-se a todas as ciências e possibilitariam previsões que seriam passíveis tanto de aplicação na natureza, quanto em relação aos homens.

Conforme Capel (1981: 271),

[...] la posibilidad de realizar predicciones es el objetivo esencial del método positivista, y deriva del postulado de que existe un orden constante y necessario de los fenómenos de la naturaleza, es cual es alcanzado a través de la inducción. ${ }^{16}$

Por volta das décadas de 1930 e 1940, período de intensa crise econômica, os métodos quantitativos que consideravam o homem e a realidade social pertencentes ao mundo físico, generalizam-se nas ciências sociais. A Geografia também foi impactada pela onda neopositivista, surgindo assim a chamada "Nova Geografia" ou "Geografia Quantitativa", que inicialmente, esforçava-se coletivamente na tentativa de elevar esse campo de investigação ao status de ciência, o que, segundo o positivismo, só seria possível a partir da utilização de métodos positivistas, ou seja, da formulação de hipóteses que pudessem ser verificadas na investigação empírica, considerando a regularidade presente na natureza.

Torna-se, nesse momento na Geografia, prática comum utilizar teorias físicas para explicar fenômenos da Geografia Humana. Nesse momento, afirma-se que "grande importância foi dada às técnicas, em especial ao uso de técnicas quantitativas, por sua precisão" (AMORIM FILHO, 1987: 11). A Cartografia com

\footnotetext{
${ }^{16}$ A possibilidade de realizar previsões é o objetivo essencial do método positivista e deriva do princípio de que existe uma ordem constante e necessária dos fenômenos da natureza, o qual é alcançado através da indução. Tradução nossa.
} 
caráter positivista aparece como uma dessas técnicas, servindo como um dos principais instrumentos de afirmação da Geografia.

Outro paradigma muito significativo em um momento da história da Cartografia foi a teoria da comunicação cartográfica, que se insere no contexto do processo de transformação dos métodos e dos objetivos ocorridos no interior da Cartografia, no período entre 1970 e 1980 (SIMIELLI, 2010).

Tendo como foco de interesse a produção de mapas, não existia, até então na Cartografia, preocupação com o usuário do mapa. A. Kolacny apresentou, em 1977, um modelo denominado Comunicação da Informação Cartográfica (KOLACNY, 1994), em que se explanava sobre os fatores que agem no processo de comunicação da informação cartográfica. Destacava-se naquela proposta a necessidade de uma integração entre o produtor de mapas e o usuário do mapa, ressaltando a necessidade de o produtor de mapas "estudar as condições internas e externas daqueles que usarão a sua criação".

Segundo Kolacny (1994: 4):

[...] ele [o produtor] deve conhecer não só as necessidades, interesses e tarefas dos usuários do mapa, mas também ter consciência do seu nível de conhecimento, habilidade e destreza, dos métodos que usam para trabalhar com o mapa, e também das condições ambientais nas quais o mapa será usado.

Estabeleciam-se assim os pressupostos elementares da Teoria da Comunicação Cartográfica, ou seja, "a cartografia passa a se preocupar com o usuário do mapa, com a mensagem transmitida e com a eficiência do mapa como meio de comunicação" (SIMIELLI, 2010: 73). A partir do modelo de Kolacny, foram criados diversos modelos ou esquemas teóricos para representar 0 processo de comunicação cartográfica. Salichtchev, ao aperfeiçoar o modelo de Kolacny, conseguiu sintetizar com simplicidade e objetividade os elementos e os processos que compõem a comunicação 
cartográfica (FIGURA 7), que mostra o mapeamento como um processo de comunicação, conforme Salichtchev ${ }^{17}$ (1978 apud MATIAS, 1996).

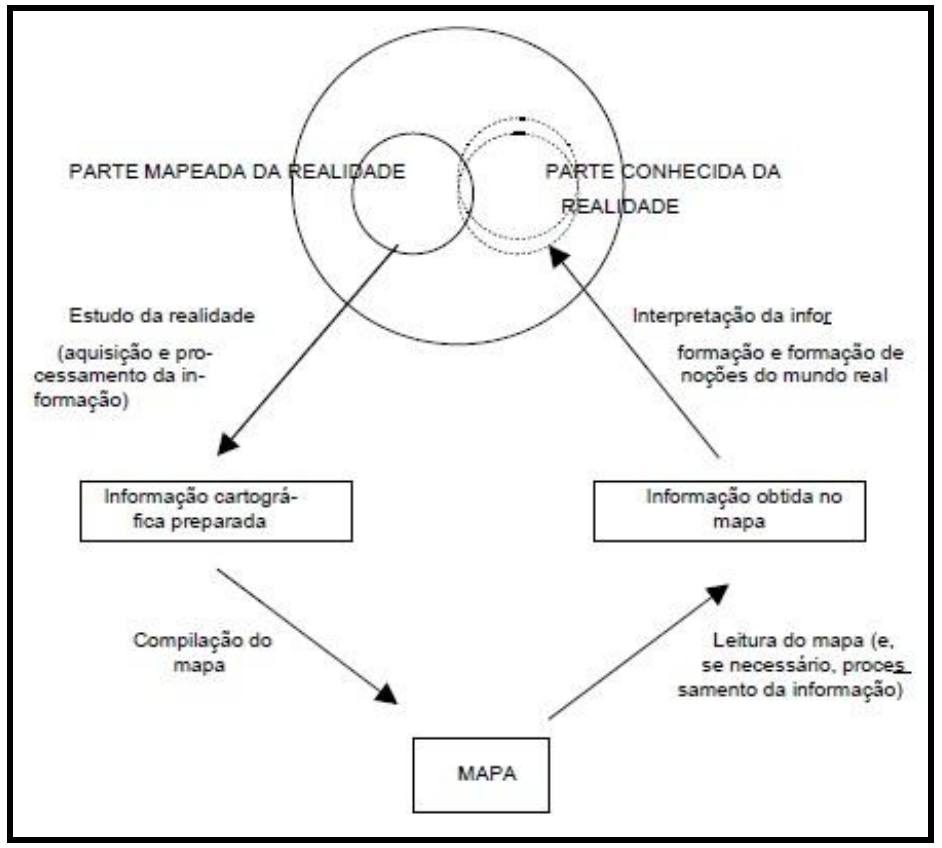

Figura 7 - Mapeamento como um processo de comunicação, segundo Salichtchev (1978). Fonte: Matias (1996: 49).

No processo de comunicação, envolvem-se o iniciador, o meio e o recebedor da informação (VASCONCELLOS, 1993), cujo modelo forma um ciclo. Simielli (2010) explica que, no esquema de Salichtchev, o ciclo da comunicação é realizado em quatro estágios. O primeiro trata da seleção da informação, o segundo estágio, compreende a compilação do mapa, em que ocorre a codificação e a generalização, havendo perda de informação. No terceiro, estágio a informação está contida nos símbolos e requer preparo do leitor. No quarto estágio da interpretação da informação pelo leitor, há a possibilidade de expansão de ideias sobre a realidade mapeada, ao mobilizarem-se os conhecimentos já adquiridos pelo leitor, além de intervir o processo cognitivo no procedimento em pauta.

Na teoria da Comunicação Cartográfica, enfatiza-se o processo em vez de um produto. Suas propostas e modelos serviram de base para um trabalho importante na Cartografia brasileira, a saber, a tese de Simielli (1986), intitulada

\footnotetext{
${ }^{17}$ Salichtchev, K. A. Cartographic communication: its place in the theory of science. The Canadian Cartographer, Toronto: University of Toronto Press, v. 15(2), p. 93- 99, 1978.
} 
O mapa como meio de comunicação, em que a autora avaliou a eficácia desse meio de comunicação pela pesquisa com a clientela a que se destina: público com faixa etária de 11 a 15 anos. Esse trabalho é tido como um referencial para muitas das práticas que se incluem no âmbito da Cartografia Escolar. De acordo com Simielli (2010: 88) a pressuposição é que "o mapa será mais eficiente se o cartógrafo confeccioná-lo para um usuário específico".

Sluter Junior (2001) afirma que a abordagem da comunicação cartográfica foi criticada por diversas razões. Entre tais críticas, o autor destaca que a comunicação cartográfica ignorou as variadas formas pelas quais as pessoas usam os mapas; ignorou também as contribuições da arte no processo cartográfico e a afirmação objetiva e imparcial de sua abordagem.

Outro paradigma que influenciou e influencia os estudos em Cartografia referese ao paradigma fenomenológico. A influência da perspectiva fenomenológica marcou muitas ciências, a partir da década de 1960, quando começavam a ecoar vozes de insatisfação, que denunciavam o descontentamento com o cientificismo neopositivista.

A insatisfação apontava a urgente necessidade de incluir-se na análise social a nova dimensão psicológica e valorizar a experiência dos sujeitos. Nesse momento, duas correntes filosóficas - a Fenomenologia e o Existencialismo aparecem como alternativas frente às abstrações do cientificismo neopositivista. A influência da Fenomenologia foi sentida primeiramente no campo da Psicologia, em contraposição à Psicologia Experimental, e em seguida na Sociologia, e propiciou o aparecimento de um interesse pelo mundo vivido pelo homem e sua experiência. Assim, a Psicologia e a Sociologia tiveram um novo rumo a partir da recuperação da experiência pessoal.

Com base nas contribuições de Yi-Fu Tuan (a respeito das questões referentes a valores ambientais de indivíduos num determinado contexto espacial, da forma como as pessoas percebem e analisam 0 ambiente de forma diferenciada) e na teoria do desenvolvimento cognitivo de Piaget, Barbara Petchenik foi uma autoras que se destacou no desenvolvimento da Teoria da Cognição, na qual a base do conhecimento é dada pela experiência vivida. 
A dimensão cognitiva dos mapas é destacada por Martinelli (1999: 25):

Por sua vez, Petchenik (1977) considera que os mapas não carregam em si os significados, mas os desencadeiam na cabeça do usuário. Os signos apreendidos pelo leitor constroem em sua mente o significado do conteúdo que foi formulado pelo construtor do mapa. Neste sentido, o significado dos mapas é resultado do arranjo espacial, não dos objetos, mas sim do conjunto de relações entre os objetos. O leitor deve reconstruir em sua mente estas relações. Neste momento, o mapa passa a ter significado. É assim que se opera a apreensão do conhecimento espacial através de mapas. Como resultado, poderemos saber onde os lugares ficam e como se estruturam, sem mesmo tê-los visitado.

Os estudos de Petchenik (1977), dentre os quais encontra-se "Cognition in Cartography", serviram de referência para Oliveira (1978) que, por sua vez, ao elaborar o "Estudo metodológico e cognitivo do mapa", influenciou toda a Cartografia Escolar que se produziu até hoje no Brasil.

Dentre os paradigmas da Cartografia, o paradigma estruturalista refere-se àquele que adotou a base estruturalista vinculada à linguística de Saussure ${ }^{18}$, para quem a língua é um fato social no sentido de que é um sistema convencional adquirido pelos indivíduos no convívio social (MUSSALIM; BENTES, 2005).

Seemann (2003: 50), tratando do poder comunicativo dos mapas, situa a Cartografia no contexto da linguagem da comunicação:

É comum tratar a Cartografia como linguagem de comunicação que se fundamenta nas teorias linguísticas de Ferdinand de Saussure, responsável por uma geração inteira de estruturalistas, não apenas na sua própria área, mas também na Antropologia (por exemplo, Lévi-Strauss) e na Cartografia (Jacques Bertin). Essa visão concebe a linguagem cartográfica como uma língua com seu próprio sistema de signos verbais (= vocabulário) e regras para o emprego desses signos (= gramática) para efeito de comunicação.

A linguagem da representação gráfica tem a mesma estrutura da linguagem da matemática. Em ambas, a monossemia não está na relação entre o significante e o significado do signo, mas sim entre os significados dos signos. Quando

\footnotetext{
${ }^{18}$ A tradição estruturalista foi iniciada por Saussure em seu Curso de Linguística Geral, de 1916. A corrente estruturalista ocupou o centro da cena teórica, a partir de 1930.
} 
colocamos entre esses dois numerais 2 e 2 este sinal +, estabelece-se entre os dois numerais uma relação de soma. Ambas são concepções "estruturalistas".

A linguagem designa um sistema utilizado pelo homem para transmitir informações. A linguagem é um ato, no qual se utilizam diversas línguas (FARACO, 1993). A língua é uma instituição social (SAUSSURE, 2006) e, nesse contexto social foi se constituindo por comodidade,

[...] da mesma forma que todas as outras, é por acaso e por simples razões de comodidade que nos servimos do aparelho vocal como instrumento da língua. Os homens também poderiam ter escolhido o gesto e empregar imagens visuais em lugar de imagens acústicas (SAUSSURE, 2006: 17).

Diversos autores destacam o caráter e a importância social da língua (SAUSSURE, 2006; FARACO, 2006, entre outros). Saussure (2006: 21) afirma que "quando ouvimos falar uma língua que desconhecemos ficamos alheios ao fato social". O autor ressalta ainda que o entendimento dos signos se dá no seu contexto e "para estudá-los é indispensável situá-los nos processos sociais globais que lhes dão significação" (SAUSSURE, 2006: 21).

Que linguagem é essa que ainda está em vir a ser conhecida pelos professores?

A linguagem da representação gráfica surge como uma tentativa de renovação teórica da Cartografia; compreende um dos caminhos teórico-metodológicos que a Cartografia seguiu em sua jornada rumo à sistematização, e refere-se à teoria da Representação Gráfica (Graphique) proposta pelo professor Jacques Bertin.

A representação gráfica é uma linguagem que se inclui no domínio da comunicação visual, que por sua vez insere-se no contexto da comunicação social (MARTINELLI, 2003; 2013).

A Cartografia deve privilegiar os níveis de leitura global, intermediário e de detalhe na construção dos documentos gráficos. Bonin (1975: 42) menciona que "uma construção gráfica eficaz deve permitir respostas a todas as 
questões que Ihe são concernentes no conjunto ou no detalhe da informação transmitida".

Dada a importância das contribuições de Bertin e a incipiente germinação de suas ideias na formação de professores de Geografia no Brasil, é oportuno, neste trabalho discutir que consequências tiveram na abordagem sobre o mapa e sobre sua elaboração, e que contribuições apresentam para o ensino de Cartografia para a Licenciatura em Geografia, principalmente quanto aos ensinamentos de Geografia.

O paradigma atual da Cartografia refere-se à visualização cartográfica, que surge no contexto do rápido progresso da tecnologia computacional. As formulações teóricas desse novo paradigma são conduzidas pelos estudos de Alan MacEachren ${ }^{19}$ (1991, 1992, 1994,1995 apud SLUTER JUNIOR, 2001) que sugere um novo entendimento de como os mapas funcionam ao serem empregados para descobrir padrões desconhecidos em fenômenos espaciais.

A visualização cartográfica constitui uma das possibilidades de interlocução da Informática e da Cartografia, relativamente recente na história da ciência cartográfica $^{20}$ (teve início na década de 1990). Isso é um novo paradigma para o trabalho com a Cartografia, usando-se todos os aparatos das novas tecnologias. Conforme Queiroz Filho (2005), a origem do termo (visualização) está associada à expansão do papel da Cartografia nas atividades científicas.

Parece haver concepções diferentes do que seria o termo visualização. Segundo Peterson (1994 ${ }^{21}$ apud QUEIROZ FILHO, 2005), a interatividade seria a chave de todo o processo de visualização. Ramos (2005) acrescenta, além

\footnotetext{
${ }^{19}$ MACEACHREN, A. M. Visualization Quality and the Representation of Uncertainty. Orono, ME, National Center for Geographic Information and Analysis, 1991.

MACEACHREN, A. M. Visualizing Uncertain Information. Cartographic Perspectives, n. 13, p. 10-19, 1992.

MACEACHREN, A. M. Some Truth With Maps: A Primer on Design and Symbolization. Washington, DC, Association of American Geographers, 1994.

MACEACHREN, A. M. How Maps Work: Representation, Visualization, and Design. New York, The Guilford Press, 1995.

${ }^{20} \mathrm{~A}$ visualização científica é bem antiga. Com as imagens dos primeiros raios $X$ já se praticava a visualização científica, indispensável para a medicina e a meteorologia, na atualidade.

${ }^{21}$ PETERSON, M.P. Cognitive issues in cartographic visualization. In: MACEACHREN, A: TAYLOR, D.R.F. Visualization in modern cartography, UK: Pergamon, 1994, p. 27-44.
} 
da interatividade, a exploração. Conforme Ramos (2005: 34), "a visualização não se relaciona com a informática, mas sim à forma como informações recebidas pelo cérebro são transformadas em conhecimento".

Aplicada à Geografia, a visualização científica assume a visualização cartográfica, âmbito de pesquisa que conta com comissão ativa na $\mathrm{ACl}$, denominada Comissão de Visualização e Ambientes Virtuais (RAMOS, 2005).

As pesquisas preocupam-se em estudar o uso de novas tecnologias para prover um instrumental exploratório para facilitar a visualização espacial de elementos que não seriam compreensíveis por meio do mapa em papel. As pesquisas buscam tornar os mapas disponíveis para um público cada vez mais amplo (RAMOS, 2005).

Ramos (2005) argumenta que a visualização cartográfica difere da Cartografia Digital e do SIG, principalmente pela questão da interatividade e da exploração. Dessa forma, a visualização refere-se mais à finalidade dos mapas do que à tecnologia empregada em sua elaboração. A finalidade dos mapas é servir como instrumento de análise exploratória e visa à construção de conhecimentos com base na exploração visual de mapas. A visualização cartográfica tem como base os conceitos elementares da Cartografia Temática, considerados indispensáveis para a elaboração de qualquer mapa.

Quanto à visualização cartográfica, Nogueira (2009: 116) comenta que fora da Cartografia, a visualização é um método da computação, em que

[...] a computação gráfica e a tecnologia de processamento de imagens são usadas em aplicações científicas de análise intensiva de dados, visando transformar o simbólico em geométrico, capacitando assim o pesquisador a observar suas simulações e cálculos.

De forma sucinta, a visualização significa utilização de métodos gráficos para análise e apresentação visual de dados. Nogueira (2009) considera a visualização como um instrumento de pesquisa científica, no qual os mapas desempenham um papel fundamental na sequência de uma pesquisa ou de um processo de análise ou planejamento. 
Queiroz Filho e Rodrigues (2007) consideram que a visualização cartográfica tem como cerne o pensamento geográfico, isso é, estimular o raciocínio sobre questões desconhecidas e auxiliar na busca de padrões e relacionamentos entre os dados. Para esses autores, visualização cartográfica e visualização geográfica têm nuances distintas. A visualização cartográfica destaca a interatividade, e a visualização geográfica incorpora o processo de tomada de decisão. O processo de visualização cartográfica, ou seja, a preocupação com a comunicação na interface de exibição do mapa para o usuário final tem uma importância essencial para a transmissão do conhecimento (MACEACHREN; KRAAK, 2001).

O cubo apresentado por MacEachren ${ }^{22}$ (1994 apud QUEIROZ FILHO, 2005: 38) faz alusão à natureza do espaço representado pelos mapas, sob a forma de um espaço cúbico com três dimensões ou eixos (FIGURA 8).

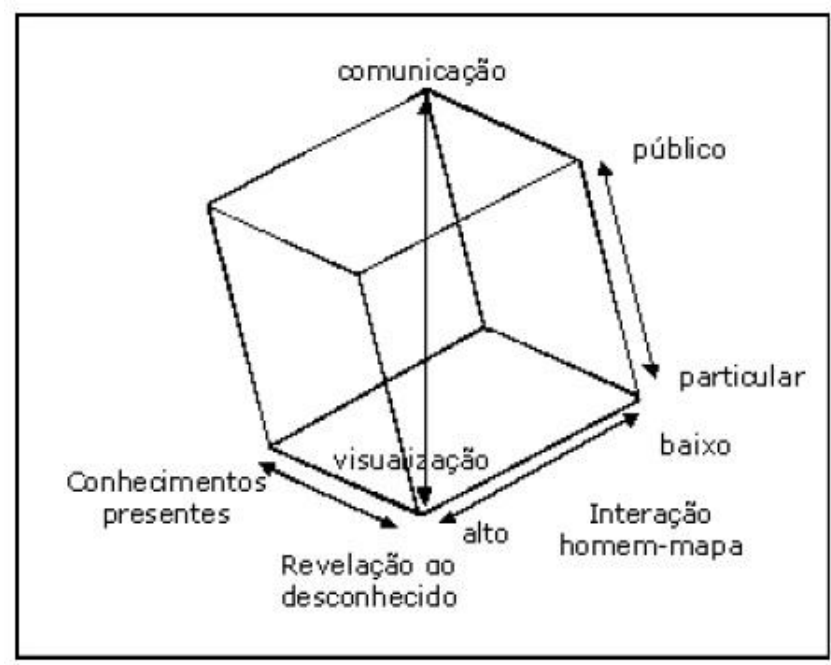

Figura 8 - A visualização cartográfica de MacEachren (1994)

Fonte: Queiroz Filho (2005: 38).

A proposta do cubo é também diferenciar a comunicação cartográfica da visualização cartográfica. Um eixo representa o propósito do mapa, que vai da apresentação da informação conhecida para revelar o desconhecido. Um

22 MACEACHREN, A. M. Visualization in modern cartography: setting the agenda. In: MACEACHREN, A: TAYLOR, D.R.F. Visualization in modern cartography, UK: Pergamon, 1994, p. 27-44. 
segundo eixo representa a continuidade do uso do mapa, que vai do domínio privado ou individual para o domínio público ou social. O terceiro eixo representa a capacidade de interação do mapa com o leitor, e pode ser uma interação baixa para uma interação. O canto, que marca o ponto de congruência da apresentação da informação conhecida, baixa interação e domínio público, define a comunicação cartográfica. O canto do cubo, que marca o ponto de congruência da revelação da informação desconhecida, de alta interação mapa-humano no domínio privado, define a visualização cartográfica (SLUTER JUNIOR, 2001).

A visualização cartográfica é a base conceitual para a Cartografia na atualidade (MARTINELLI, 2013; TAYLOR, 2007). Apesar de não equivaler à Cartografia, a visualização cartográfica envolve três de seus aspectos básicos: novas técnicas de produção cartográfica, comunicação e cognição (MARTINELLI, 2010). A Figura 9 mostra a base conceitual para a Cartografia (TAYLOR ${ }^{23}$, 1994 apud MARTINELLI, 2010). Note-se nessa figura que a cognição é a grande contribuição que o esquema dá à Cartografia, e que já vinha sendo enfatizada por Petchenik (1977).

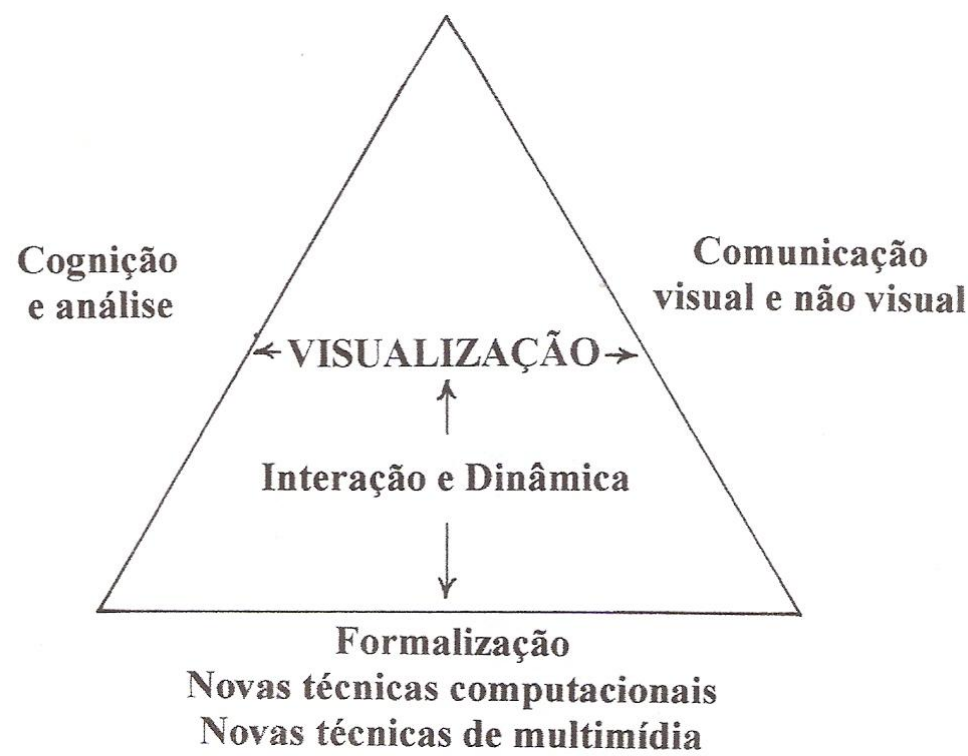

Figura 9 - Base conceitual para a Cartografia, conforme Taylor Fonte: Martinelli, 2010, p. 214.

${ }^{23}$ Taylor, D. R. F. Perspectives on visualization and modern cartography. In: MACEACHREN, A.M; TAYLOR, D.R.F. (eds.). Visualization in modern cartography. Londres: Elseiver Science, 1994. 
A visualização cartográfica, como base conceitual para a Cartografia, tem impulsionado a necessidade de um novo termo: a cibercartografia. Segundo Taylor (2007), tal conceito teria sido introduzido num artigo apresentado na Conferência da $\mathrm{ACl}$, ocorrida em 1997. O novo termo vem reafirmar e demonstrar a importância dos mapas e a centralidade e a utilidade da Cartografia na era da informação.

Taylor (2007) destaca sete elementos principais da cibercartografia, dos quais podemos inferir a natureza holística dessa nova concepção:

1) É multissensorial usando visão, audição, tato e eventualmente, cheiro e sabor.

2) Usa formatos multimídias e novas tecnologias da comunicação como a internet.

3) É altamente interativa.

4) Aplica-se a uma gama variada de tópicos de interesse da sociedade, não somente à localização e ao ambiente físico.

5) Não é um produto isolado como um mapa tradicional; é parte de um pacote de informações.

6) É organizado por uma equipe de especialistas de diversas áreas.

7) Envolve novas parcerias de pesquisa como academia, governo, sociedade civil e o setor privado.

Diante de sua centralidade no contexto da era da informação, que demandas esse novo paradigma da Cartografia traria para a formação de professores que, como inferimos, ainda não dá conta do básico em Cartografia? Essa é uma das questões que discutimos, ao detectar a necessidade de um repensar, de novo olhar sobre a Cartografia na formação acadêmica de professores de Geografia.

\subsection{Cartografia Escolar}

A linha de pesquisa Cartografia para Escolares, no Brasil e no mundo, tem se mostrado um campo promissor. Mesmo sendo recente a organização dos congressos e colóquios, nota-se uma produção significativa dos pesquisadores dessa área de trabalho. A realização desses eventos é de suma importância, pois representa um momento de divulgação dos resultados dos trabalhos, trocas de experiências e discussões em torno do tema Cartografia para, e por crianças. Além disso, permite, por meio dos trabalhos apresentados e da participação dos pesquisadores, delinear temas de pesquisas que vêm se 
consolidando a cada evento. No contexto dos estudos em Cartografia têm se observado trabalhos influenciados por diferentes paradigmas.

Os trabalhos em Cartografia Escolar discutidos nos colóquios inserem-se na interface de três grandes campos de conhecimento: Cartografia, Geografia e Educação. A Cartografia engloba a abordagem temática com o uso da Semiologia Gráfica. Com a utilização do material didático-pedagógico e dos recursos tecnológicos disponíveis é possível trabalhar a aquisição de habilidades que envolvem os conceitos geográficos e a representação espacial contribuindo, assim, para o processo de ensino-aprendizagem.

Um dos desafios existentes, na interação das três áreas, está centrado na formação de professores, aos quais é preciso fornecer bases para a abordagem dos temas da Cartografia para Escolares nas salas de aula. $O$ atual estágio das pesquisas apresentadas nos colóquios permite identificar uma significativa produção na linha de Cartografia para Escolares, no Brasil, na qual se observam alguns direcionamentos básicos.

Diversos autores vêm se dedicando às discussões sobre as possibilidades da Cartografia nas séries iniciais e têm concluído que a Cartografia deve ser utilizada não como um conteúdo, mas sim como uma linguagem. Isso significa dizer que nas séries iniciais, não vamos ensinar a Cartografia, vamos ensinar através da Cartografia. A aprendizagem dessa linguagem deve dar-se a partir do espaço de vivência dos alunos, conforme Callai (2005: 244):

Desenhar trajetos, percursos, plantas da sala de aula, da casa, do pátio da escola pode ser o início do trabalho do aluno com as formas de representação do espaço. São atividades que, de um modo geral, as crianças dos anos iniciais da escolarização realizam, mas nunca é demais lembrar que o interessante é que as façam apoiadas nos dados concretos e reais e não imaginando/fantasiando. Quer dizer, tentar representar o que existe de fato.

Cabe ressaltar a necessidade de todo um cuidado com as etapas do desenvolvimento mental das crianças, como aponta Oliveira (1978) apoiada nos estudos de Piaget. Tais ensinamentos não podem passar despercebidos. $\mathrm{Na}$ aprendizagem dessa linguagem é importante ter clareza dos diversos 
momentos: a construção da noção de espaço pelas crianças, a representação do espaço, a aprendizagem da Geografia a partir das representações do espaço. Nas séries iniciais, no que compete à Geografia, é imprescindível a aprendizagem de noções espaciais. Diversas pesquisas na área do Ensino de Geografia apontam para a importância de trabalhar a Cartografia como linguagem na construção dessas noções e não como um conteúdo, como já ressaltamos.

Nessa fase do ensino, são desenvolvidas habilidades de leitura e de escrita da língua oficial e de lidar com os números. É nessa fase que se deve desenvolver também a habilidade de lidar com a leitura do espaço (ALMEIDA e PASSINI, 1994; CALLAI, 2005; LESANN, 2009). Essa habilidade é bem abrangente, como mostra Callai (2005: 228-229):

Fazer a leitura do mundo não é fazer uma leitura apenas do
mapa, ou pelo mapa, embora ele seja muito importante. É fazer
a leitura do mundo da vida, construído cotidianamente e que
expressa tanto as nossas utopias, como os limites que nos são
postos, sejam eles do âmbito da natureza, sejam do âmbito da
sociedade (culturais, políticos, econômicos). Ler o mundo da
vida, ler o espaço e compreender que as paisagens que
podemos ver são resultado da vida em sociedade, dos homens
na busca da sua sobrevivência e da satisfação das suas
necessidades. Em linhas gerais, esse é o papel da Geografia
na escola.

Ao invés de dar o conteúdo pronto, o professor deve ser o coordenador das atividades realizadas pelos alunos. Essas atividades devem ter o objetivo de desenvolver a capacidade de observação e de comparação de dados, a fim de que, ao estabelecer generalizações, o aluno seja capaz de produzir suas próprias explicações a respeito dos fenômenos observados.

Almeida (1991: 86) afirma que,

Partindo do conhecimento adquirido através da observação do meio circundante, conhecimento esse ainda não sistematizado, o aluno deve ter a oportunidade de contribuir para a elaboração de um arcabouço, formado por ideias conceitos e categorias, que lhe permitam interpretar de forma cada vez mais profunda, a realidade que o cerca.

De acordo com Almeida (1991), o professor das séries iniciais deve estar atento aos seguintes procedimentos: 
- partir da reflexão sobre os alunos: quem são, onde moram, como é sua vida escolar, quais são seus anseios e dificuldades, como é sua vida familiar, qual sua condição social;

- propor metas claras quanto ao ensino de Geografia a serem atingidas durante o período letivo;

- elaborar um plano de trabalho juntamente com os alunos;

- avaliar os alunos quanto ao seu desempenho e em função do processo desenvolvido.

Callai (2005: 228-229) analisa a Geografia escolar da seguinte maneira:

[...] da forma como a Geografia tem sido tratada na escola tradicionalmente, ela não tem muito a contribuir. Aquela Geografia chamada tradicional, caracterizada pela enumeração de dados geográficos e que trabalha espaços fragmentados, em geral opera com questões desconexas, isolando-as no interior de si mesmas, em vez de considerá-las no contexto de um espaço geográfico complexo, que é o mundo da vida.

Para superar essa situação, é importante entender que a aprendizagem espacial é a razão de existir da Geografia nas séries iniciais. Para tanto, é preciso considerar que o espaço não é neutro, e a noção de espaço que a criança desenvolve não é um processo natural e aleatório. A noção de espaço é construída socialmente, de forma cada vez mais ampla e complexa. A capacidade de percepção e a possibilidade de sua representação são um desafio que motiva a criança a desencadear a procura, a aprender a ser curiosa, para entender o que acontece ao seu redor, e não ser simplesmente espectadora da vida. Há uma reafirmação da importância da construção da habilidade de leitura do espaço:

Ao partir da vivência concreta, busca-se a ampliação do espaço da criança com a aprendizagem da leitura desses espaços e, como recurso, desenvolve-se a capacidade de aprender a pensar o espaço, desenvolvendo raciocínios geográficos, incorporando habilidades e construindo conceitos (CALLAI, 2005: 243)

É preciso desenvolver a capacidade de aprender a pensar o espaço, o que requer a habilidade de trabalhar com representações desse espaço. Para ler 0 
espaço, torna-se necessário um outro processo de compreensão da linguagem cartográfica (CALLAI, 2005: 243). Isso significa entender que a Geografia é uma forma de compreender o mundo em que vivemos; que é por meio da Geografia, nas aulas dos anos iniciais do Ensino Fundamental, que os alunos podem encontrar uma maneira interessante de conhecer o mundo, de se reconhecerem como cidadãos e de serem agentes atuantes na construção do espaço em que vivem.

Callai (2005) afirma que os alunos precisam aprender a fazer análises geográficas, por meio do conhecimento do mundo, a partir do lugar em que vivem, a fim de que compreendam o que são os processos de exclusão social e a seletividade dos espaços em que todos estão inseridos.

A linguagem cartográfica deve ser trabalhada como uma metodologia para a construção do conhecimento geográfico. André e Bailly (1989) discutem a utilização didática das representações espaciais, cujo conceito é chave para compreender o comportamento e a ação dos homens e da sociedade no espaço. André (1998: 103) reafirma essa importância acrescentando que "introduire la réalité des représentations dans les représentations de la réalité permet de compreendre pourquoi les pratiques de l'espace sont ce qu'elles sont" ${ }^{24}$. Então, se a representação espacial contribui para a explicação espacial de um objeto de estudo da Geografia, sua descoberta e sua análise devem ser integradas ao processo de aprendizagem.

A introdução e o trabalho com representações espaciais devem incluir-se no ensino da Geografia, a fim de se descobrir e estudar os processos espaciais. Essas considerações contribuem para mostrar como as representações gráficas em mapas são importantes na compreensão da organização do espaço.

Relativamente aos conhecimentos cartográficos no ensino de Geografia na Educação Básica, há diversas orientações de estudiosos que podem contribuir muito na direção da construção da metodologia. Para Lesann (2009), os

\footnotetext{
24 "introduzir a realidade das representações nas representações da realidade permite compreender porque as práticas do espaço são o que são". Tradução da autora.
} 
conceitos são constituídos pela acumulação de noções que são apreendidas ao longo do tempo. A autora discute a lógica da construção do conhecimento, segundo a qual podem ser estabelecidos cinco grupos de habilidades/ações pensando-se o processo de aquisição do conhecimento:

[...] o primeiro passo é constituído pelas ações que giram em torno da observação, o segundo corresponde à análise das observações, seguido de síntese. A partir da síntese, é possível interpretar para finalizar o processo de construção, portanto, de aquisição de nosso conhecimento (LESANN, 2009: 43).

Lesann (2009) explica que as cinco fases descritas devem ser trabalhadas em cada ano do Ensino Fundamental, de modo a permitir a construção de competências em Geografia. Para Lesann (2009), os conceitos fundamentais da Geografia são espaço, escala, tempo e representação. Para a sedimentação desses conceitos, a construção do conhecimento deve seguir uma lógica, definida pela autora, como árvore conceitual, compreendida pela abordagem e pela construção de noções mais simples, indispensáveis à construção de noções mais complexas.

Ao refletir sobre a importância dos conhecimentos geográficos na atualidade, Cavalcanti (1998: 11) entende que o papel da Geografia na vida dos alunos

[...] é o de prover bases e meios de desenvolvimento e ampliação da capacidade dos alunos de apreensão da realidade sob o ponto de vista da espacialidade, ou seja, de compreensão do papel do espaço nas práticas sociais e destas na configuração do espaço.

Dessa forma, para Cavalcanti (1998), a produção e a organização do espaço pelas sociedades se dão em função da própria subsistência, e articulam-se com os modos culturais e os materiais disponíveis. Nesse sentido, o pensar geográfico, segundo a autora, contribui para situar o aluno como cidadão do mundo em que vive, por meio da espacialização dos fenômenos nas diversas escalas. Assim, compartilhamos neste trabalho do entendimento da autora, segundo a qual, o conhecimento geográfico é indispensável à formação dos indivíduos na vida social, na medida em que propicia o entendimento do espaço geográfico e do papel desse espaço nas práticas sociais. 
Sob essa perspectiva, os conhecimentos cartográficos são imprescindíveis, pois possibilitam um desvendar das informações a respeito do espaço em questão. 


\section{A CARTOGRAFIA NAS ORIENTAÇÕES CURRICULARES PARA A GEOGRAFIA NO ENSINO FUNDAMENTAL E MÉDIO}

\begin{abstract}
O que se ensina, se sugere ou se obriga a aprender, expressa os valores e funções que a escola difunde num contexto social e histórico concreto. Por isso, a resposta à pergunta do que se considera relevante ser ensinado não é simples, nem pode ser elaborada unicamente desde posições pedagógicas, psicológicas ou desde uma determinada filosofia, já que o ensino não opera no vazio. É preciso abordar todas as determinações que recaem sobre a escola em geral e especialmente sobre o currículo.
\end{abstract}

J. Gimeno Sacristán

Ao analisar a história do pensamento geográfico, percebemos que a Geografia como ciência apresentou mudanças de abordagens e preocupações a fim de explicar com mais consistência a relação entre homem e natureza. As atuais abordagens do conhecimento geográfico no Brasil resultam de várias correntes de pensamento.

Conforme Pontuschka et al. (2007: 38) "alguns pesquisadores orientam-se teórica e metodologicamente com maior ênfase por correntes do neopositivismo; outros, por correntes humanísticas e psicológicas da Geografia da percepção."

Em relação ao ensino, observa-se que, a Geografia no âmbito escolar, de maneira geral, ainda parece estagnada no viés tradicional que reflete uma disciplina de caráter decorativo e de preocupações superficiais, pois não insere o aluno como agente transformador do espaço. A Geografia como disciplina escolar deveria oferecer elementos que permitissem aos professores e aos alunos conhecimento sobre as múltiplas dimensões da realidade social, natural e histórica, e melhor entendimento do mundo em seu processo ininterrupto de transformação (PONTUSCHKA et al., 2007: 37).

Castellar e Vilhena (2010) tecem importantes considerações sobre a questão do ensino de Geografia. Especificamente, em relação à Cartografia, as autoras 
têm posicionamentos que entendemos ser fundamentais ao se considerar a razão de ser da Cartografia no ensino de Geografia bem como a da importância dessa temática na formação do professor. Castellar e Vilhena (2010: 25) entendem que "na Geografia escolar, o estudo dos fenômenos pode ser mais interessante para o aluno alfabetizado ou letrado a partir da linguagem cartográfica". As autoras afirmam também que

A Cartografia como uma técnica de representar os lugares, e
todos os conceitos (escala, fuso horário, coordenadas
geográficas, projeções cartográficas e tipos de mapas) são
importantes de serem trabalhados. Mas é fundamental
entendê-la como uma linguagem e também como uma
metodologia na educação geográfica (CASTELLAR; VILHENA,
2010:28).

Compartilhando essas concepções, afirmamos que além de um conhecimento sobre a Geografia como ciência e disciplina escolar, deve estar presente na formação do professor de Geografia o conhecimento da Cartografia como técnica e como linguagem da representação gráfica, posto que "a Cartografia tem um papel a desempenhar na construção da cidadania" (FONSECA, 2004:111).

De acordo com a Lei de Diretrizes e Bases da Educação Nacional (LDBEN 9394/96), foram elaborados os Parâmetros Curriculares Nacionais (BRASIL, 1997, 1998), que instituem uma base curricular nacional comum. Os Parâmetros Curriculares Nacionais (PCNs) com novas orientações curriculares, segundo a visão de alguns autores, revisam o papel da Cartografia, antes vista como um mero conjunto de técnicas auxiliares ao ensino de Geografia, compreendida agora como linguagem de representação dos fenômenos geográficos.

Em Minas Gerais, por sua vez, o Conteúdo Básico Comum (CBC) representa a proposta curricular desenvolvida no ano de 2005, pela Secretaria de Educação do Estado de Minas Gerais (SEEMG) destinada às escolas da rede pública mineira. A nova proposta partiu de um presumido desgaste do ensino em relação aos seus conteúdos e abordagens, considerado desvinculado da realidade dos alunos. 
Analisamos, então, as duas orientações curriculares ( $P C N$ e $C B C$ ) para 0 ensino de Geografia no Ensino Fundamental e Médio, pressupondo que essas orientações, em âmbitos diferentes - esfera nacional e esfera estadual trazem implicações relativas ao trabalho do professor em sala de aula. A discussão dessas orientações pode apontar também implicações sobre a formação acadêmica do professor de Geografia. As duas orientações curriculares compõem a análise aqui realizada. A análise de tais propostas curriculares norteou-se pelos seguintes questionamentos: Como a proposta foi gestada? Como está organizada a proposta curricular? De que forma, a proposta contempla a dimensão cartográfica no processo do Ensino de Geografia?

Em nossa análise, verificamos a estruturação da Cartografia nas orientações curriculares oficiais correntes para o Ensino Fundamental e Médio, e buscamos compreender de que forma, essas propostas curriculares contemplam a dimensão cartográfica no processo do ensino de Geografia.

Em que pese a influência das reformas educacionais nos currículos, em tese, não podemos negar que é a proposta oficial que orienta o trabalho dos professores. Nesse sentido, entendemos ser mais produtivo trazê-las para a discussão com os professores, para que juntos, os atores envolvidos no processo da educação possam repensar e pensar novas propostas curriculares adequadas à realidade vivenciada nas escolas.

As referidas orientações são consideradas documentos oficiais e, portanto, utilizamos a denominada análise documental, técnica valiosa para abordagem dos dados qualitativos (LUDKE; ANDRÉ, 1986). Os documentos são considerados uma fonte estável e rica de pesquisa, pelo fato de persistirem ao longo do tempo, podendo ser consultados conforme o necessário, possibilitando mais estabilidade aos resultados obtidos na investigação qualitativa em Educação.

Assim, serão analisados os seguintes documentos: 
- Parâmetros Curriculares Nacionais para o Ensino Fundamental, $1^{\circ}$ e $2^{\circ}$ ciclos (BRASIL, 1997);

- Parâmetros curriculares Nacionais para o Ensino Fundamental, $3^{\circ}$ e $4^{\circ}$ ciclos (BRASIL, 1998);

- Parâmetros Curriculares Nacionais (PCN+ Ensino Médio) Ciências Humanas e suas tecnologias (BRASIL, 1999);

- Parâmetros Curriculares Nacionais para o Ensino Médio (BRASIL, 2000);

- Proposta Curricular de Geografia - CBC 6 ao 9 ano (MINAS GERAIS, 2008);

- Proposta Curricular de Geografia - CBC Ensino Médio (MINAS GERAIS, 2008).

Para permitir uma visão da Cartografia dentro das respectivas orientações curriculares de Geografia, optamos por apresentar os quadros constantes nos documentos, dando destaque para a Cartografia. Após a apresentação dos quadros, são apresentadas formulações e ideias a respeito dos mesmos.

\subsection{Parâmetros Curriculares Nacionais}

Uma das mudanças na organização escolar decorrentes da LDBEN diz respeito ao currículo.

Segundo o Art. 9, da LDBEN, parágrafo IV, fica a cargo da União

[...] estabelecer, em colaboração com os Estados, o Distrito Federal e os Municípios, competências e diretrizes para a educação infantil, o ensino fundamental e o ensino médio, que nortearão os currículos e seus conteúdos mínimos, de modo a assegurar formação básica comum.

Para cumprir esse direcionamento, foram elaborados os Parâmetros Curriculares Nacionais, com o objetivo de representar uma referência nacional de currículo. O documento elaborado seguiu os princípios postulados pelo Banco Mundial, de controle do governo na saída do processo educativo, 
mediante avaliação. Nesse sentido, o Ministério da Educação e Cultura (MEC), na segunda metade dos anos 1990, adotou uma política educacional centralizadora, desprezou boa parte dos debates e proposições curriculares dos estados e apresentou "os Parâmetros Curriculares Nacionais, no âmbito de uma política educacional neoliberal que atingiu todo o território nacional" (PONSTUSCHKA; PAGANELLI; CACETE, 2007: 78).

O processo de elaboração dessa orientação curricular é considerado por alguns como extremamente questionável por excluir a participação dos educadores da Escola Básica. Diversos autores contestam a aplicabilidade desses documentos da forma como foram elaborados e, simplesmente disponibilizados nas escolas.

Braga (1998: 24) declara que

No processo de construção dos PCN ocorreu uma verdadeira ruptura entre as iniciativas do Estado e as das organizações da sociedade civil. As associações científicas e/ou profissionais não participaram das discussões que resultaram na construção dos PCN, e quando surgiu alguma tentativa de romper o cisma, o resultado foi mais a cristalização do afastamento do que o contrário.

O resultado dessa afirmação citada se vê no próprio texto dos PCNs, considerado extremamente teórico para o professor da Educação Básica que tem, muitas vezes, como principal fonte de pesquisa o livro didático. Além disso, os PCNs foram "elaborados em momentos diferentes, por equipes diferentes, adaptando referenciais diversos" (PONSTUSCHKA; PAGANELLI; CACETE, 2007: 81).

\subsubsection{Pressupostos teóricos orientadores da proposta dos PCNs}

Um dos referenciais adotados pelos PCNs na formulação dos objetivos e na avaliação é a divisão dos conteúdos em conceituais, procedimentais e atitudinais de acordo com Coll. Também está presente no texto dos PCNs a abordagem de competências e habilidades de Perrenoud (1999) (MARANGON; LIMA, 2002).

César Coll é professor da Universidade de Barcelona e foi um dos participantes 
da reforma educacional espanhola, modelo positivo para os formuladores dos PCNs. Coll foi consultor de equipes responsáveis por diversos documentos componentes dessa proposta curricular. Entre outras influências na formulação dos PCNs, provém de Coll a divisão dos conteúdos em conceituais, procedimentais e atitudinais.

Os conteúdos conceituais referem-se à construção ativa de capacidades intelectuais para a aprendizagem de conceitos ou princípios. Os conteúdos procedimentais referem-se às regras, técnicas, aos métodos, ou seja, à construção de um conjunto de ações ordenadas com um fim, e dirigidas para a realização de um objetivo. Os conteúdos atitudinais estariam relacionados à formação de valores e de atitudes em relação à informação recebida e às normas que conduzem a essas atitudes.

Moreira (1997) faz críticas à teorização do currículo em Coll, destacando suas limitações, entre as quais, a associação ao pensamento tradicional de currículo, considerando-o demasiadamente prescritivo e marcado por um caráter psicologizante. Seria prescritivo no sentido de que propõe um "desenho orientador do trabalho docente", a partir de ações consideradas úteis e eficazes, em que a primazia das discussões refere-se ao como fazer, em detrimento de outras mais, ou menos importantes. O caráter psicologizante se estabelece quando a psicologia construtivista é utilizada para preservar

[...] a noção do conhecimento como um processo biológico e natural (isolado das funções sociais e políticas da escolarização) e para obscurecer as relações de controle e de poder necessariamente presentes no processo educacional (MOREIRA, 1997: 100).

A teorização do currículo em Coll é psicologizante também, porque prioriza o processo cognitivo do estudante e a organização dos saberes escolares, revelando uma preocupação com o como ensinar em detrimento de o que ensinar (MOREIRA, 1997).

Além disso, Moreira (1997) afirma que a abordagem do currículo em Coll, negligencia as complexas relações entre educação e sociedade e aponta limitações quanto à teorização do currículo em Coll: 
Não se analisam os efeitos que mudanças no currículo e na prática pedagógica podem provocar na formação da consciência do estudante e, como consequência na organização social. Não se acentua que a Educação tem sido utilizada para reproduzir uma estrutura social hierarquizada e conservar determinados grupos sociais em situação de opressão e submissão. Não se pondera o fato de que a sociedade tem colocado a escola mais a serviço da manutenção da ordem que da promoção do desenvolvimento de seus membros. Como resultado, o processo educativo é despido de seus aspectos ideológicos e políticos, e o currículo acaba sendo visto como elemento neutro de transmissão cultural. Ou seja, deixa-se de inserir as decisões curriculares, necessariamente referentes à cultura e a significados, nas lutas políticas e econômicas de que tais significados são uma expressão (MOREIRA, 1997:95).

Os PCNs fundamentam-se na proposta teórica denominada construtivismo. Nessa perspectiva, a aprendizagem é considerada um processo de aquisição de conhecimentos que exige do aprendiz atuação como sujeito sobre o objeto, a fim de transformá-lo. O simples contato com o conhecimento não implica sua aquisição. É preciso ação por parte de quem aprende. Esse é um pressuposto, aliás, muito interessante na formulação dos PCNs.

Contudo, o ecletismo nas concepções teóricas "dificulta a compreensão e a apropriação das mudanças na terminologia e na forma de abordagem dos conteúdos" pelo professor em sala de aula (PONSTUSCHKA; PAGANELLI; CACETE, 2007: 81).

\subsubsection{A Cartografia no Ensino Fundamental I conforme os PCNs}

Os PCNs para o Ensino Fundamental ${ }^{25}$ (FIGURA 10) foram publicados em volumes. As tradicionais disciplinas foram mantidas em áreas e foram eleitos temas transversais (Ética, Saúde, Meio Ambiente, Orientação Social, Pluralidade Cultural, Trabalho e Consumo) que devem permear as discussões e os projetos desenvolvidos pelas áreas. 


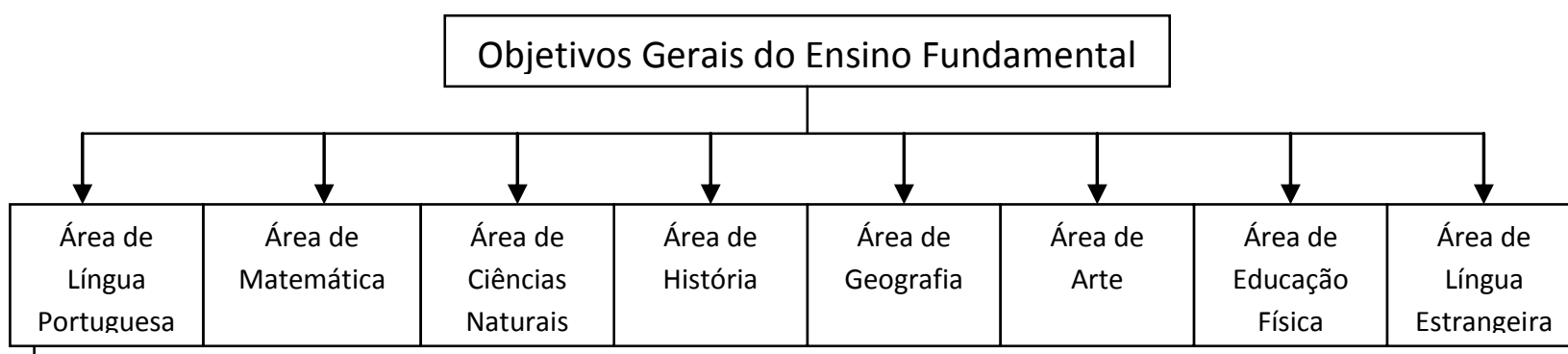

Ética - Saúde - Meio Ambiente - Orientação Social - Pluralidade Cultural - Trabalho e Consumo

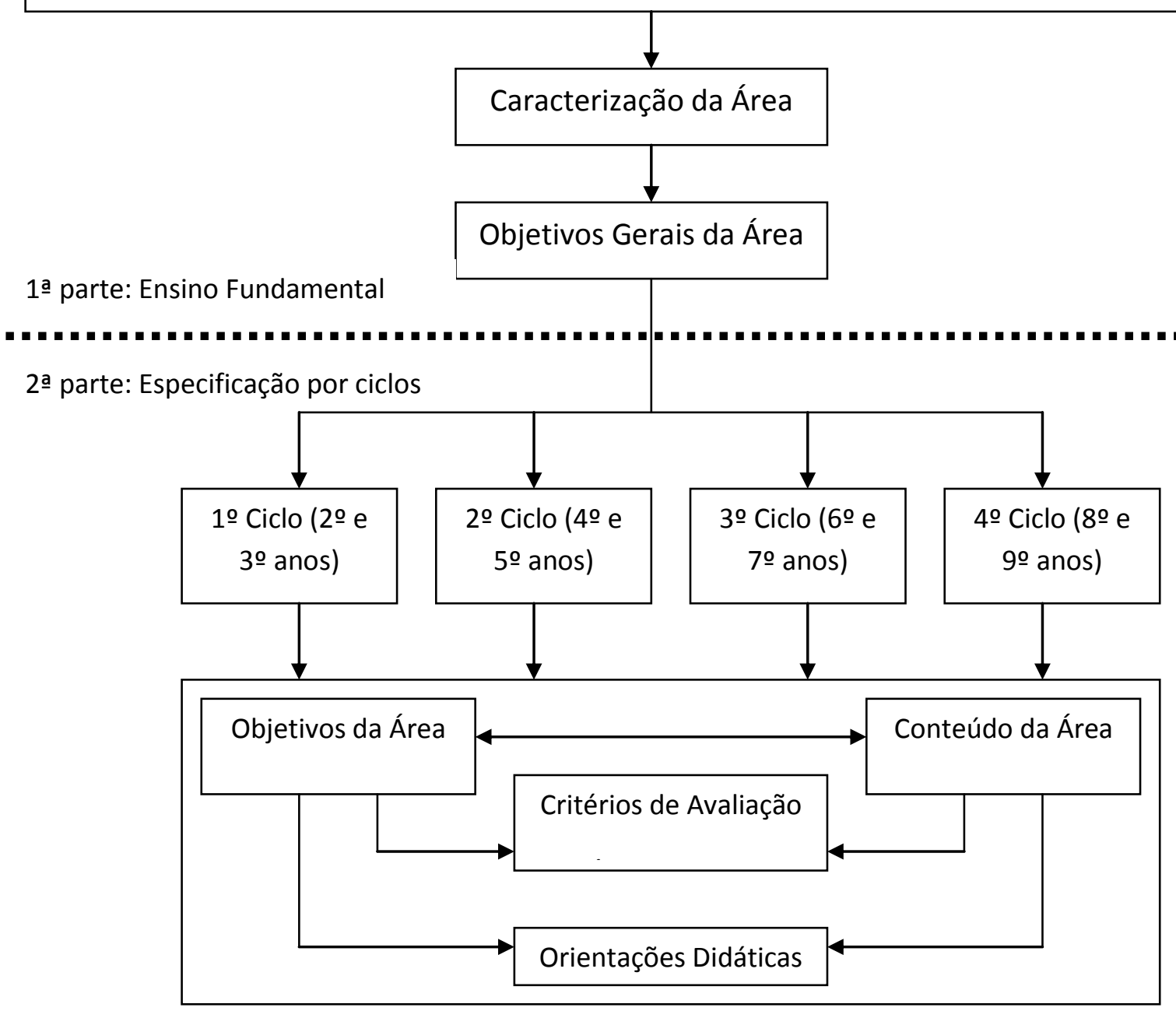

Figura 10 - PCNs Ensino Fundamental

Fonte: Brasil, 1997: 9.

Nos PCNs, a área da Geografia foi tratada em dois volumes. Um abrange os dois primeiros ciclos do Ensino Fundamental ${ }^{26}$ (do $1^{\circ}$ ao $5^{\circ}$ ano) e o outro, os terceiro e quarto ciclos (do 6o ao 9o ano). Os PCNs de Geografia estão organizados em duas partes. A primeira apresenta uma caracterização da área

\footnotetext{
${ }^{26} \mathrm{Na}$ época de elaboração dos PCNs (BRASIL, 1995), o ensino Fundamental I ainda era composto por 4 séries. O ensino Fundamental I passou a contar com um ano a mais. Daí, as crianças passaram a ingressar na escola aos 6 anos de idade.
} 
da Geografia, do ensino e da aprendizagem dessa disciplina no Ensino Fundamental; os objetivos gerais e os critérios de seleção e de organização dos conteúdos de Geografia. Na segunda parte, estão explicitados os objetivos específicos de cada ciclo, os blocos temáticos, os conteúdos, os critérios de avaliação e as orientações didáticas.

Segundo os PCNs, a Geografia, ao explicar o mundo por meio da leitura crítica, a partir da paisagem e suas imagens, "poderá oferecer uma grande contribuição para decodificar as imagens manipuladoras que a mídia constrói na consciência das pessoas, seja em relação aos valores socioculturais ou a padrões de comportamentos políticos nacionais" (BRASIL, 1998: 29).

Em relação ao ensino da Geografia, os Parâmetros Curriculares Nacionais (BRASIL, 1997: 99; 1998: 15) propõem

[...] um trabalho pedagógico que visa à ampliação das capacidades dos alunos do ensino fundamental, de observar, conhecer, explicar, comparar e representar as características do lugar em que vivem e de diferentes paisagens e espaços geográficos.

A proposta pedagógica disposta no documento oficial, referente à Geografia, inaugura um novo momento de reflexão em relação às velhas práticas aplicadas nessa disciplina. Os problemas de ordem epistemológica e de pressupostos teóricos que permanecem nas propostas curriculares elaboradas nas últimas décadas foram analisados no texto dos parâmetros curriculares (BRASIL, 1997: 106-108):

As mudanças nos referenciais curriculares nacionais são uma medida importante para a superação da representação social desta disciplina, construída ao longo de sua trajetória de institucionalização nas escolas. Essa representação social, presente no imaginário dos alunos e efetivada na prática dos professores diz respeito, principalmente, ao ensino conteudista baseado na memorização e descrição de nome de rios, capitais e outras denominações.

O documento considera que o espaço geográfico é o objeto central do estudo, mas que as categorias paisagem, território e lugar devem também ser abordados por que se mostram mais acessíveis aos alunos, devido às características cognitivas e afetivas da faixa de idade dos alunos dos ciclos 
iniciais (BRASIL, 1997).

Conforme o documento, ao abordar tais categorias, a Geografia utiliza diversas linguagens, entre as quais a da literatura, da música, da fotografia e do cinema. Entre as diferentes linguagens, os PCNs de $1^{\circ}$ ao 5ํano (BRASIL, 1997: 118), destacam a Cartografia:

(a Geografia) pede uma cartografia conceitual, apoiada numa fusão de múltiplos tempos e numa linguagem específica, que faça da localização e da espacialização uma referência da leitura das paisagens e seus movimentos.

Sem apresentar demais referências do que seria essa Cartografia conceitual, o documento deixa transparecer certa confusão de palavras, dificultando o entendimento das orientações para o professor do ensino fundamental.

Os PCNs indicam ser preciso superar as formas usuais de se trabalhar com a linguagem cartográfica (colorir, copiar, memorizar nomes nos mapas), que não garantiriam que os alunos construíssem conhecimentos necessários para ler os mapas e para representar o espaço geográfico. O papel da escola seria criar oportunidade para isso.

O papel da Cartografia aparece mais uma vez entre os objetivos da Geografia para todo o Ensino Fundamental. O texto declara a expectativa de que os alunos construam conhecimentos que Ihes permitam ser capazes de, entre outros objetivos, "saber utilizar a linguagem cartográfica para obter informações e representar a espacialidade dos fenômenos geográficos" (BRASIL, 1997: 122).

A proposta dos PCNs considera que a Cartografia insere-se no conjunto das diferentes linguagens da Geografia, o que é uma perspectiva interessante, pois a Cartografia é a principal linguagem da qual se vale a Geografia para expressar a espacialidade dos fenômenos, seu objeto central de estudo. Além disso, a proposta aponta que os alunos devem ser esclarecidos quanto à importância de conhecerem o espaço, saber representá-lo e adquirir as habilidades necessárias para a leitura dos documentos cartográficos que lhes são apresentados, salientando que 
A escola deve criar oportunidades para que os alunos construam conhecimentos sobre essa linguagem nos dois sentidos: como pessoas que representam e codificam o espaço e como leitores das informações expressas por ela (BRASIL: 1997: 119).

Parece haver o entendimento de que os PCNs para o ensino de Geografia valorizam a Cartografia. Para alguns autores, os PCNs como novas orientações curriculares, revisam o papel da Cartografia, antes vista como um mero conjunto de técnicas auxiliares ao ensino de Geografia e compreendida agora como linguagem de representação dos fenômenos geográficos. O documento demonstra a pressuposição de que a alfabetização cartográfica é um processo que permite o desenvolvimento de habilidades como observar, classificar e comparar, o que possibilitaria o contato e a ação do sujeito sobre os objetos, alvo do conhecimento. É o que mostram diversos trabalhos como os de Felbeque (2003) e de Ferreira (2009), que discorrem sobre a Cartografia nos PCNs de Geografia.

Ferreira (2009: 52) considera que

[...] a maior influência do construtivismo no ensino de Geografia encontra-se na Cartografia. Isso ocorre porque a teoria piagetiana contribui para que o professor reconheça como os alunos, em diferentes faixas, constroem as noções básicas de espaço. Do ponto de vista do construtivismo, a construção da noção de espaço requer longa preparação e está associada à liberação progressiva e gradual do egocentrismo que a criança exerce nos primeiros anos de vida. A construção das relações espaciais requer a interação do sujeito com o meio em que vive e realiza-se através da liberação progressiva e gradual do egocentrismo primitivo.

Contudo, ao longo da proposta dos PCNs, certas afirmações demonstram que seus formuladores tinham entendimentos distorcidos da Cartografia, como se observa no seguinte trecho:

O estudo sobre a representação do espaço segue de modo semelhante ao primeiro ciclo, embora seja possível abordar de forma mais aprofundada as noções de distância, direção e orientação e iniciar um trabalho mais aprofundado com as noções de proporção e escala. Já se pode esperar que os alunos compreendam que para representar o espaço é preciso obedecer a certas regras e convenções postuladas pela linguagem cartográfica e comecem a dominá-las na produção 
de mapas simples, relacionados ao espaço vivido e outros mais distantes. Atividades nas quais os alunos tenham que refletir, questionar, comunicar e compreender informações expressas por meio dessas regras e convenções - e não apenas descrevê-las e memorizá-las - podem ser planejadas pelo professor para que as conheçam e aprendam a utilizá-las. Os referenciais de localização, os pontos cardeais, as divisões e contornos políticos dos mapas, o sistema de cores e legendas podem e devem ser trabalhados (BRASIL, 1997: 142). (Grifo da autora).

A incongruência nesse trecho reflete um entendimento equivocado do que seja a Cartografia na atualidade. O texto cita a necessidade de obedecer a regras e a convenções, o que contraria a perspectiva da Cartografia como linguagem da representação gráfica, na qual não há opção pelo uso de convenções.

Para Martinelli (2013: 13),

A representação gráfica compõe uma linguagem gráfica bidimensional, atemporal e destinada à vista. [...] sua especificidade reside no fato de estar fundamentalmente vinculada ao âmago das relações que podem se dar entre os significados dos signos. Interessa-nos, portanto, ver instantaneamente as relações entre aqueles que significam relações entre objetos referentes, evidentemente após ter controlado tal relação entre o significado e o significante dos signos. Dispensa qualquer convenção constituída. É o domínio das operações mentais lógicas.

Ao assumir a Cartografia como linguagem é preciso que os leitores aprendam a linguagem dos mapas com fundamentos da Cartografia Temática em bases semiológicas, como aponta Martinelli (2013).

O Quadro 1 mostra o levantamento dos objetivos, itens e procedimentos ligados à Cartografia, presentes nos PCNs. Foram encontradas muitas indicações distribuídas ao longo dos eixos temáticos e dos ciclos de ensino, conforme se destacam no quadro. 
QUADRO 1: Objetivos, itens e procedimentos ligados à Cartografia, nos PCN do $1^{\circ}$ e $2^{\circ}$ ciclos do Ensino Fundamental

\begin{tabular}{|c|c|c|}
\hline & Objetivos & Procedimentos \\
\hline $1^{\circ}$ ciclo & $\begin{array}{l}\text { - reconhecer, no seu cotidiano, os } \\
\text { referenciais espaciais de localização, } \\
\text { orientação e distância de modo a } \\
\text { deslocar-se com autonomia e representar } \\
\text { os lugares onde vivem e se relacionam } \\
\text { (131). }\end{array}$ & $\begin{array}{l}\text { - produção de mapas ou de roteiros } \\
\text { simples, considerando características } \\
\text { da linguagem cartográfica como as } \\
\text { relações de distância e de direção e o } \\
\text { sistema de cores e legendas; } \\
\text { - leitura inicial de mapas políticos, de } \\
\text { atlas e do globo terrestre (135). }\end{array}$ \\
\hline $2^{\circ}$ ciclo & $\begin{array}{l}\text { - saber utilizar os procedimentos básicos } \\
\text { de observação, descrição, registro, } \\
\text { comparação, análise e síntese na coleta } \\
\text { e tratamento da informação, seja } \\
\text { mediante fontes escritas ou imagéticas; } \\
\text { - utilizar a linguagem cartográfica para } \\
\text { representar e interpretar informações em } \\
\text { linguagem cartográfica, observando a } \\
\text { necessidade de indicações de direção, } \\
\text { distância, orientação e proporção para } \\
\text { garantir a legibilidade da informação } \\
\text { (144). }\end{array}$ & $\begin{array}{l}\text { - levantamento, seleção e } \\
\text { organização de informações, a partir } \\
\text { de fontes variadas, como fotografias, } \\
\text { mapas, notícias de jornal, filmes, } \\
\text { entrevistas, obras literárias, músicas, } \\
\text { etc.; } \\
\text { - representação em linguagem } \\
\text { cartográfica das características das } \\
\text { paisagens estudadas por meio da } \\
\text { confecção de diferentes tipos de } \\
\text { mapas, observando a necessidade de } \\
\text { indicar a direção, a distância e a } \\
\text { proporção, para garantir a legibilidade } \\
\text { das informações; } \\
\text { - leitura e compreensão das } \\
\text { informações expressas em linguagem } \\
\text { cartográfica e em outras formas de } \\
\text { representação do espaço, como } \\
\text { fotografias aéreas, plantas, } \\
\text { maquetes, entre outras (149). }\end{array}$ \\
\hline
\end{tabular}

Fonte: Brasil (1997). (Organizado pela autora).

Considerando o objetivo relacionado à Cartografia no primeiro ciclo $\left(1^{\circ}\right.$ e $2^{\circ}$ anos), verifica-se mais uma inconsistência teórica na orientação curricular. Quando se define, entre os objetivos, o reconhecimento dos referenciais de distância, os formuladores da proposta demonstram desconhecer que a noção de distância é muito complexa para o $1^{\circ}$ ano, pois é necessário que a criança já tenha construído a noção de proporção.

Ainda nos procedimentos para o $1^{\circ}$ ciclo, organizados no Quadro 1, mistura-se o sistema de cores com legendas, o que dificulta a aprendizagem da Cartografia pelas crianças, se os professores optarem por seguir essas orientações; outro equívoco dos formuladores da proposta. Vale ressaltar que a construção de legendas não se restringe ao sistema de cores, mas consiste em organizar os símbolos escolhidos e escrever ao lado os respectivos significados. 
Conforme o Quadro 1, os objetivos e os procedimentos indicados $\left(4^{\circ}\right.$ e $5^{\circ}$ anos), orientam que no $2^{\circ}$ ciclo o aluno utilizará o tratamento da informação para construir documentos cartográficos. Os Parâmetros indicam o raciocínio de análise e de síntese no trabalho de coleta e de manipulação da informação, mas o documento não menciona o raciocínio lógico como procedimento primordial nesse processo, conforme destaca Martinelli (2013) ao realçar o domínio das operações mentais lógicas.

Depois de serem identificadas algumas impertinências na proposta curricular oficial, podemos afirmar que a forma como se apresentam os objetivos e os procedimentos demonstra que os formuladores descuidaram-se ao deixar expresso no texto a necessidade de se considerar e respeitar as etapas do desenvolvimento mental das crianças. Um exemplo é a questão da noção de distância, que requer o desenvolvimento de noções de relações espaciais que, por sua vez, passam primeiro por noções elementares, ditas relações espaciais topológicas, seguidas de relações projetivas para, posteriormente, passar para a construção do conceito de distância. Sobre esse assunto, é possível destacar a contribuição de estudiosos da Cartografia Escolar, que fornecem fundamentos para as críticas acima apresentadas.

Para Almeida, nos procedimentos da proposta dos PCNs, há apropriação de práticas destinadas ao ensino de mapas ao adulto "aquele mapa que se usa na aula de Geografia" (ALMEIDA, 2001: 10), e desconsideram-se os conhecimentos elaborados pelos alunos, práticas que levam à "confusão entre as tarefas propostas e os conceitos a serem aprendidos" (ALMEIDA, 2001: 11).

Partindo da constatação dessa controvérsia, ALMEIDA (2001) realizou atividades para o ensino de mapas, a partir de considerações teóricas sobre representação do espaço por crianças, e as classificou como metodologia para iniciação cartográfica.

No Quadro 2, visualizam-se as atividades e os respectivos conhecimentos ligados à representação do espaço. 
QUADRO 2: Atividades e respectivos conhecimentos relativos à representação do espaço

\begin{tabular}{l|l}
\hline Atividade & Conhecimentos relativos à representação do \\
espaço
\end{tabular}

Fonte: Almeida (2001: 101).

A construção das noções espaciais é importante para todo o aprendizado no Ensino Fundamental I. Diversos autores concordam que o aprendizado dessas noções demanda um trabalho interdisciplinar. Uma dessas autoras é Lesann (2009), cuja contribuição ainda está sendo difundida entre os professores da Educação Básica.

Lesann (2009) discute a necessidade de se retomar o objetivo da fase do ensino denominada de Fundamental. Conforme a autora, na fase de escolarização, que vai do $1^{\circ}$ ao $5^{\circ}$ ano ou Ensino Fundamental I, 
construção dos conceitos estruturantes de qualquer disciplina/matéria, sendo a Geografia uma delas (LESANN, 2009: 65).

Compartilhando também do entendimento de Almeida (2001), de que o desenvolvimento de noções espaciais deve ser 0 alvo das ações dos professores da fase do Ensino Fundamental I (1ํa a $5^{\circ}$ ano), Lesann (2009) e diversos autores (ALMEIDA; PASSINI, 1994; CALAI, 2005) entendem que se deve desenvolver também a habilidade de lidar com a leitura do espaço. Suas formulações fundamentam-se no tripé do Ensino proposto por Biddle, ilustrado pela Figura 11.

Tripé do Ensino Tradicional Literacia

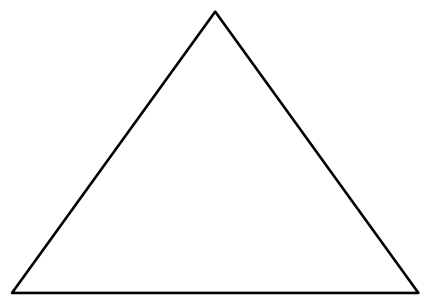

Numeracia
Tripé do Ensino proposto por Bidlle Literacia e articulacia

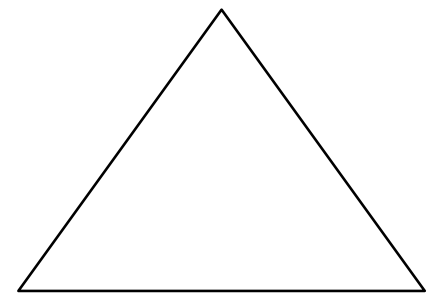

Graficacia

Figura 11 - Tripé do ensino tradicional, proposto por Biddle Fonte: Lesann (2009: 65-66).

A Figura 11 mostra que, no Ensino Fundamental tradicional, são privilegiadas as habilidades básicas: literacia, habilidade da escrita; articulacia, habilidade da fala; numeracia, habilidade de lidar com os números. Na proposta de Biddle ${ }^{27}$ (1978 apud LESANN, 2009) ${ }^{28}$, a habilidade de lidar com o espaço é tão fundamental quanto saber ler e lidar com os números, e deve ser trabalhada nas séries iniciais.

Ao longo de sua trajetória profissional, Lesann (2009) desenvolveu diversos estudos voltados para a construção do conhecimento pelas crianças, principalmente, tendo como meio a Cartografia. Como parte de seus estudos, a

\footnotetext{
${ }^{27}$ BIDDLE. D. S. Abordagem conceitual do Ensino da Geografia na escola secundária. Ageteo, texto n. 2. Rio Claro, 1978.

${ }^{28}$ Uma controvérsia existe, aqui, sobre a autoria desse conceito. Talvez a autoria mais antiga seja BALCHIN (1972), em artigo intitulado "Graphicacy", publicado na revista Geography, 55, p. 185-195. BALCHIN teria publicado na revista Ageteo, Rio Claro, no ano de 1978, mas que infelizmente não está disponível, pois está em fase de editoração.
} 
autora desenvolveu uma proposta do $1^{0}$ ao $5^{\circ}$ ano com valor indicativo e demonstrativo. Para Lesann (2009), o processo de aquisição do conhecimento geográfico pode ser entendido da maneira ilustrada na Figura 12:

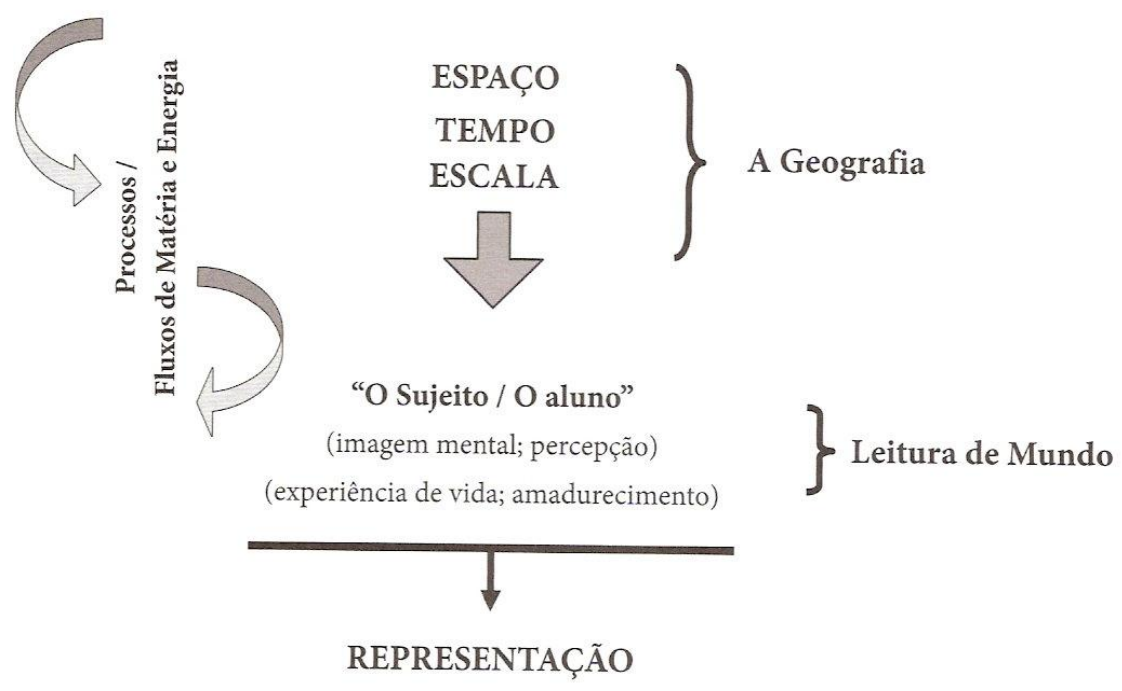

Figura 12 - Processo de aquisição do conhecimento geográfico: da Geografia à representação do espaço geográfico

Fonte: Lesann (2009: 27).

A Geografia é uma área do conhecimento que estuda os processos espaciais, sendo eles naturais ou socioculturais envolvidos na produção do espaço. Esses processos são caracterizados por uma intensa dinâmica que se manifesta em diferentes escalas temporais e espaciais; essa seria a essência da Geografia. A autora afirma que, além desses conceitos que são estruturadores, existem inúmeros conceitos complementares que devem ser apreendidos.

Em obra publicada em 2009, Lesann apresenta uma proposta de construção de cada um dos conceitos da Geografia: para cada conceito fundamental foi estruturada uma árvore lógica. A árvore lógica traz a ideia de que é preciso construir noções mais simples, indispensáveis à construção de noções mais complexas.

Para Lesann (2009), o aprendizado se dá ao longo do tempo em que a criança vai passando por diversas etapas, adquirindo noções gerais como a verbalização, que passa a ser juntamente com a alfabetização um avanço no 
processo de construção do conhecimento. Até o $5^{\circ}$ ano, é importante solidificar alguns conceitos e habilidades básicos para o estudo da Geografia. Os conceitos específicos da Geografia, que serão desenvolvidos nas séries posteriores, dependem muito da apreensão das noções básicas. Dessa forma, pode-se entender que o trabalho que o pedagogo desenvolve com as crianças nas fases iniciais é determinante para todo o processo de aprendizagem.

Em 2009, Lesann apresentou uma proposta para o Ensino Fundamental I (ANEXO A), em que podemos notar que, em cada ano escolar, vão se construindo habilidades que são a base para a aquisição ou a construção de novas habilidades nos anos seguintes, num processo gradativo.

Tanto as atividades de Almeida (2001), como a proposta de Lesann (2009) consideram que a noção de espaço é construída pelas crianças, gradativamente, num processo que parte do espaço vivido, passa pelo espaço percebido até a construção da noção de espaço concebido.

O espaço vivido refere-se ao espaço físico, vivenciado por meio do movimento e do deslocamento. O espaço percebido é aquele que não precisa mais ser experimentado fisicamente. Assim, "a análise do espaço passa a ser feito através da observação". A noção do espaço concebido ocorre por volta dos 1112 anos, período em que as crianças são capazes de estabelecer relações espaciais por meio de sua representação, "é capaz de raciocinar sobre uma área retratada em um mapa, sem tê-la visto antes" (ALMEIDA; PASSINI, 1994: 27).

Neste trabalho, optamos por apresentar as ideias dessas autoras por considerar que as noções espaciais são basilares para todo o aprendizado, e que a fase do Ensino Fundamental I é o momento em que se deveria destinar todas as atenções para a possibilidade da construção dessas noções. Entendemos que os PCNs não expressam essas concepções.

Ainda é importante ressaltar que os estudos de Almeida (2001) e Lesann (2009) poderiam servir de orientação para os professores dessa etapa da escolarização, que geralmente são pedagogos com formação generalista. Tais 
estudos devem ser levados em conta pelos professores, ao considerarem a Cartografia nos PCNs.

Também é necessário garantir que a formação dos professores atuantes no Ensino Fundamental I contemple tais concepções em seus currículos. Infelizmente, isso está no campo do "vir a ser", ou seja, é algo que ainda precisa acontecer.

\subsubsection{A Cartografia no Ensino Fundamental II conforme os PCNs}

Os PCNs de Geografia do $3^{\circ}$ e $4^{\circ}$ ciclos do Ensino Fundamental II compreendem a etapa que vai do $6^{\circ}$ ao $9^{\circ}$ ano. Para essa fase, os PCNs indicam a opção de se trabalhar a Geografia por meio de grandes eixos temáticos e com temas transversais.

Consta no texto dos PCNs que "o ensino de Geografia nesses ciclos pode intensificar ainda mais a compreensão, por parte dos alunos, dos processos envolvidos na construção das paisagens, territórios e lugares" (BRASIL, 1998: 32). Ressalta o texto também a importância do estudo da linguagem cartográfica desde o início da escolaridade, dada sua contribuição para que "os alunos venham a compreender e utilizar uma ferramenta básica da Geografia, os mapas, como também para desenvolver capacidades relativas à representação do espaço" (BRASIL, 1998: 33).

A linguagem cartográfica situa-se entre os objetivos gerais da área da disciplina Geografia:

Espera-se que, ao longo dos oito anos do ensino fundamental, os alunos construam um conjunto de conhecimentos referentes a conceitos, procedimentos e atitudes relacionados à Geografia, que lhes permita ser capazes de:

- conhecer o mundo atual em sua diversidade, favorecendo a compreensão, de como as paisagens, os lugares e os territórios se constroem;

- identificar e avaliar as ações dos homens em sociedade e suas consequências em diferentes espaços e tempos, de modo que construam referenciais que possibilitem uma participação propositiva e reativa nas questões socioambientais locais; 
- conhecer o funcionamento da natureza em suas múltiplas relações, de modo que compreendam o papel das sociedades na construção do território, da paisagem e do lugar;

- compreender a espacialidade e temporalidade dos fenômenos geográficos estudados em suas dinâmicas e interações;

- compreender que as melhorias nas condições de vida, os direitos políticos, os avanços tecnológicos e as transformações socioculturais são conquistas ainda não usufruídas por todos os seres humanos e, dentro de suas possibilidades, empenharse em democratizá-las;

- conhecer e saber utilizar procedimentos de pesquisa da Geografia para compreender a paisagem, o território e o lugar, seus processos de construção, identificando suas relações, problemas e contradições;

- orientá-los a compreender a importância das diferentes linguagens na leitura da paisagem, desde as imagens, música e literatura, de dados e de documentos de diferentes fontes de informação, de modo que interpretem, analisem e relacionem informações sobre o espaço;

- saber utilizar a linguagem gráfica para obter informações e representar a espacialidade dos fenômenos geográficos;

- valorizar o patrimônio sociocultural e respeitar a sociodiversidade, reconhecendo-os como direitos dos povos e indivíduos e elementos de fortalecimento da democracia. (BRASIL, 1998: 34-35). (Grifo da autora).

$\mathrm{Na}$ proposta dos PCNs para o Ensino Fundamental II, os conteúdos foram organizados em eixos temáticos, temas e itens. Para cada tema sugerem-se alguns itens, cabendo "ao professor selecionar e criar outros, de acordo com o seu programa de curso, sua realidade local, possibilidades de trabalho, enfim, elencar conteúdos pertinentes à sua região" (BRASIL, 1998: 40).

No terceiro ciclo (6ํㅜ e $7^{\circ}$ anos), os objetivos ligados à Cartografia são:

- reconhecer a importância da cartografia como uma forma de linguagem para trabalhar em diferentes escalas espaciais as representações locais e globais do espaço geográfico; - criar uma linguagem comunicativa, apropriando-se de elementos da linguagem gráfica utilizada nas representações cartográficas; reconhecer, no seu cotidiano, os referenciais espaciais de localização, orientação e distância, de modo que se desloquem com autonomia e representem os lugares onde vivem e se relacionam (BRASIL, 1998: 53-54). 
Para o $3^{\circ}$ ciclo, os PCNs propõem os seguintes eixos temáticos:

- A Geografia como uma possibilidade de leitura e compreensão do mundo.

- O estudo da natureza e sua importância para o homem.

- O campo e a cidade como formações socioespaciais.

- A cartografia como instrumento na aproximação dos lugares e do mundo.

A Cartografia aparece como um dos eixos temáticos que são apresentados resumidamente no Anexo $\mathrm{B}$, do qual interessa-nos analisar as informações constantes do Quadro 3:

\section{QUADRO 3: Excerto das propostas dos PCN para o $3^{\circ}$ ciclo}

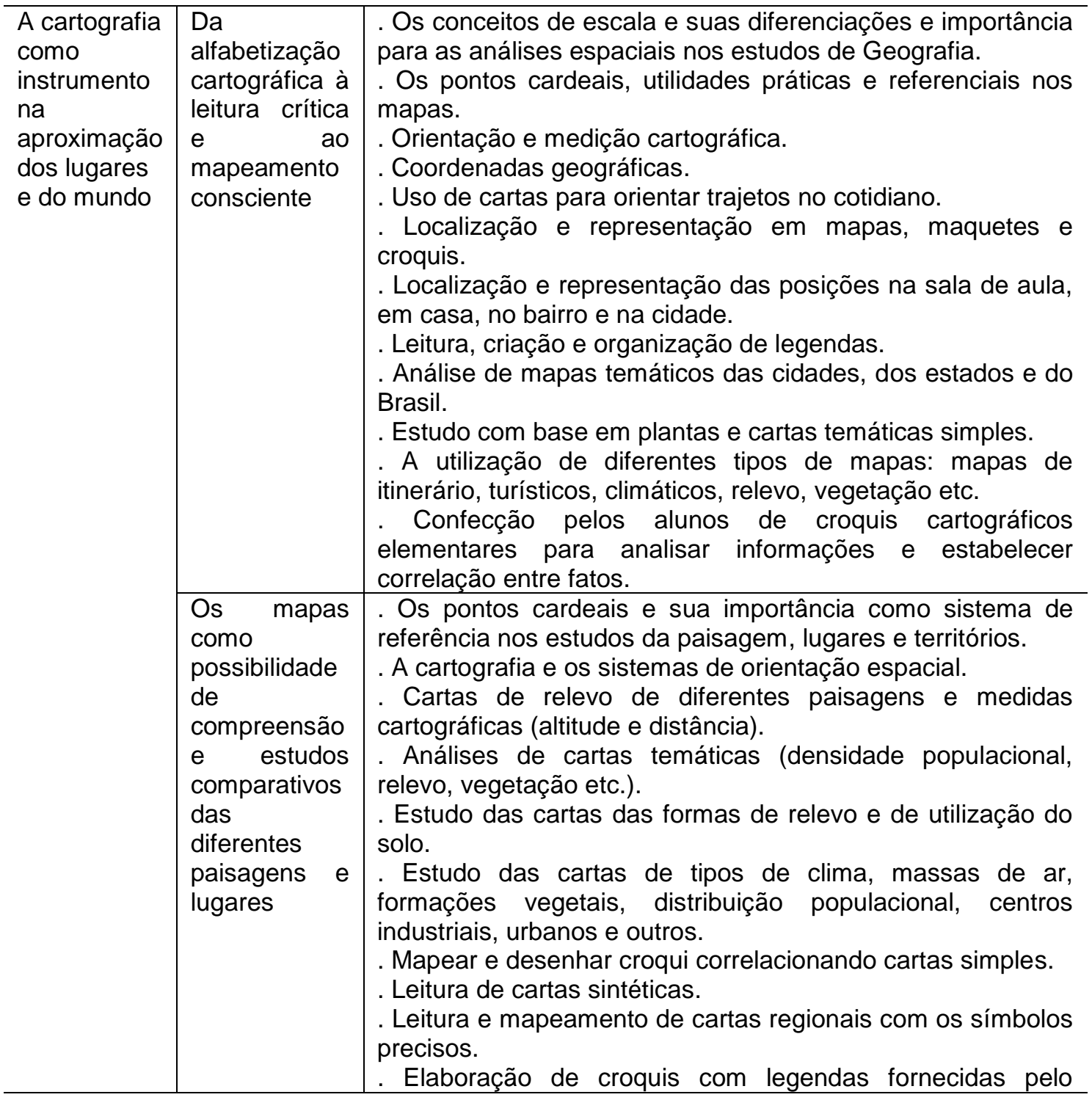




\begin{tabular}{l|l}
\hline & $\begin{array}{l}\text { professor. } \\
\text { Análise de cartas temáticas que apresentam vários } \\
\text { fenômenos. } \\
\text { - Identificar, compilar e produzir mapas intermediários dos } \\
\text { elementos fundamentais a partir de uma carta complexa. }\end{array}$ \\
\hline
\end{tabular}

Fonte: Brasil (1998: 86).

No primeiro tema "Da alfabetização cartográfica à leitura crítica e mapeamento consciente", os itens apontados encontram-se listados aleatoriamente, não sendo possível identificar uma organização condizente com a denominação desses itens. Num primeiro momento, os itens poderiam ser agrupados relacionando-se à alfabetização cartográfica procedidos dos outros itens complementares à leitura crítica e mapeamento consciente.

No tema "Os mapas como possibilidade de compreensão e estudos comparativos das diferentes paisagens e lugares" também não foi possível notar uma correlação interna dos itens, alguns ordenados e complementares (por exemplo, os procedimentos de estudo antecedem a análise das cartas).

No item de elaboração de croquis com legendas fornecidas pelo professor, pode-se questionar o fato de as legendas serem dadas pelo professor. No momento de elaboração de legendas é importante que os alunos possam testar suas hipóteses e perceber a melhor forma de representar as informações, e com elas analisar a organização.

As noções cartográficas situam-se entre os critérios procedimentais de avaliação, pois estabelecem que o aluno seja capaz de "ler diferentes cartas em diferentes escalas, apropriando-se da representação cartográfica em seu cotidiano". A pretensão é que,

Com este critério avalia-se se o aluno é capaz de distinguir e criticar aquelas mais adequadas para elaborar pequenos esboços sobre a realidade que vive ou que pretende estudar (BRASIL, 1998: 86).

No quarto ciclo ( $8^{\circ}$ e $9^{\circ}$ anos), o documento destaca que, quanto ao ensino e à aprendizagem de Geografia a expectativa é que,

O aluno possa trabalhar com a representação como leitor crítico e consciente, dando continuidade aos conteúdos de cartografia que já vinham sendo tratados no terceiro ciclo. 
Portanto, a cartografia continua sendo um meio para representar, ler, criticar a realidade do aluno do quarto ciclo que pode trabalhar a análise de mapas, plantas e croquis e fazer correções para construir sínteses do espaço geográfico (BRASIL, 1998: 93).

Em outra parte, o texto dos PCNs vincula a Cartografia às tecnologias:

O quarto ciclo é marcado pelo mundo da diversidade da cultura jovem, nesse sentido, o aluno poderá, na medida do possível e do acesso, aprender a utilizar a tecnologia como ferramenta intermediária da Geografia, a exemplo do computador como armazenador e organizador de dados empíricos, ou para construir simulações simples da realidade. Na cartografia, podem-se ampliar as possibilidades do trabalho com os seus pressupostos básicos da representação espacial: a localização, a proporção, a distância, a perspectiva, a linguagem gráfica, o trabalho com mapeamento consciente, cartas analíticas e de síntese etc. Na leitura cartográfica o professor desse ciclo pode lançar mão dos diferentes tipos de mapas temáticos, atlas, globo terrestre, plantas e maquetes mais sofisticadas. Outra possibilidade, que também depende dos recursos, são as formas de registro e interpretação espacial, como o exercício de utilização das fotografias aéreas e imagens de satélites (BRASIL, 1998: 97-98) (Grifo da autora)

Dentre os objetivos desse ciclo, destacam-se aqueles que remetem à Cartografia, a saber:

- fazer leituras de imagens, de dados e de documentos de diferentes fontes de informação, de modo que interprete, analise e relacione informações sobre o território e os lugares e as diferentes paisagens;

- utilizar a linguagem gráfica para obter informações e representar a espacialidade dos fenômenos geográficos;

- fortalecer o significado da cartografia como uma forma de linguagem que dá identidade à Geografia, mostrando que ela se apresenta como uma forma de leitura e de registro da espacialidade dos fatos, do seu cotidiano e do mundo.

(BRASIL, 1998, p. 99-100).

Para o 4ํㅜㄹ ciclo, os eixos temáticos são ( $O$ quadro completo é apresentado no Anexo C):

- A evolução das tecnologias e as novas territorialidades em redes.

- Um só mundo e muitos cenários geográficos.

- Modernização, modos de vida e a problemática ambiental. 
No 4ํㅗㅅㅡ, não há um eixo específico para a Cartografia como no ciclo anterior. Os itens aparecem genericamente relacionados aos conteúdos a serem desenvolvidos nos eixos temáticos. Não encontramos itens específicos relacionados aos objetivos da Cartografia, à exceção do item "Mapeamento dos conflitos contemporâneos no mundo" do eixo "Um só mundo e muitos cenários geográficos".

A ausência de itens e de procedimentos específicos que ressaltem a continuidade do trabalho com a linguagem cartográfica pode ocasionar uma falsa interpretação das orientações. A Cartografia não pode ser associada apenas ao conteúdo do ciclo anterior, pelo fato de ela estar presente em um eixo separado ${ }^{29}$. É necessário que o professor perceba a importância da Cartografia como uma linguagem que permeia todos os ciclos.

Depois da apresentação dos objetivos e dos procedimentos intrínsecos aos conhecimentos cartográficos contidos nos PCNs para o Ensino Fundamental, podemos afirmar sua riqueza e abrangência, e que a Cartografia tem um potencial reconhecido oficialmente pelas orientações curriculares. Contudo, ressaltamos, em concordância com Almeida (2001: 18) que,

[...] apesar do destaque que esse documento deu à Cartografia ser um avanço, cabe dizer que se cometeu o mesmo equívoco encontrado nos livros didáticos, ou seja, concentrar o assunto em um único tópico do programa curricular, como se a representação pudesse ser separada dos conteúdos representados.

Destaque-se ainda que os conhecimentos e as habilidades de representação espacial devem ser desenvolvidos ao longo de todas as séries do Ensino Fundamental, pois "na verdade, são habilidades ligadas à leitura e à escrita no sentido amplo de leitura e compreensão do mundo. Ler e escrever, em Geografia, exige domínio da linguagem cartográfica" (ALMEIDA, 2001: 18).

\footnotetext{
${ }^{29}$ Essa situação é comum em muitos livros didáticos, que tratam a Cartografia como conteúdo das séries iniciais do Ensino Fundamental II.
} 


\subsubsection{A Cartografia no Ensino Médio conforme os PCNs}

De acordo com as já mencionadas reformas educacionais iniciadas nos anos 1990, o Ensino Médio passou a integrar a Educação Básica. A reforma curricular estabelece que, no ensino Médio, a divisão do conhecimento escolar será organizada em três áreas: Linguagens, Códigos e suas tecnologias; Ciências da Natureza, Matemática e suas tecnologias e Ciências Humanas e suas tecnologias. A Geografia integra a área de Ciências Humanas e suas tecnologias.

O primeiro documento de Geografia para o Ensino Médio foi divulgado em 1999, no qual, na parte dos conhecimentos de Geografia, o objeto de estudo é o espaço geográfico, definido a partir dos estudos de Milton Santos como:

[...] conjunto indissociável de sistemas de objetos (redes, técnicas, prédios, ruas) e de sistemas de ações (organização do trabalho, produção, circulação, consumo de mercadorias, relações familiares e cotidianas), que procura revelar as práticas sociais dos diferentes grupos que nele produzem, lutam, sonham, vivem e fazem a vida caminhar (BRASIL, 1999: 310).

O documento aponta ainda que:

No ensino médio, o aluno deve construir competências que permitam a análise do real, revelando as causas e efeitos, a intensidade, a heterogeneidade e o contexto espacial dos fenômenos que configuram cada sociedade (BRASIL, 1999: 311).

O documento PCN+ (BRASIL, 2002) foi lançado como orientação complementar ao documento de 1999, e considera que a Geografia tem como conceitos estruturadores: o espaço geográfico, a paisagem, o lugar, o território, a escala, a globalização, técnicas e redes. Para cada conceito, o documento apresenta a concepção norteadora e elementos de aprofundamento. 
conceito de escala apresenta-se como mostra o Quadro 4.

QUADRO 4: Conceito de escala

\begin{tabular}{|c|c|c|}
\hline Conceito & Concepção norteadora & Elementos de aprofundamento \\
\hline Escala & $\begin{array}{l}\text { Distinguem-se dois tipos ou duas visões básicas: } \\
\text { a escala cartográfica e a escala geográfica. A } \\
\text { primeira delas é, a priori, uma relação matemática } \\
\text { que implica uma relação numérica entre a } \\
\text { realidade concreta e a realidade representada } \\
\text { cartograficamente. } \\
\text { No caso da escala geográfica, trata-se de uma } \\
\text { visão relativa a elementos componentes do } \\
\text { espaço geográfico, tomada a partir de um } \\
\text { direcionamento do olhar científico: uma escala de } \\
\text { análise que procura responder aos problemas } \\
\text { referentes à distribuição dos fenômenos. }\end{array}$ & $\begin{array}{l}\text { Para a escala cartográfica, é } \\
\text { essencial estabelecer os valores } \\
\text { numéricos entre o fato } \\
\text { representado e a dimensão real } \\
\text { do fato ocorrente. No entanto, } \\
\text { essa relação pode pressupor a } \\
\text { escolha de um grau de } \\
\text { detalhamento que implique a } \\
\text { inclusão de fatos mais ou menos } \\
\text { visíveis, dentro de um processo } \\
\text { seletivo que considere graus de } \\
\text { importância para o processo de } \\
\text { representação. } \\
\text { No caso da escala geográfica, o } \\
\text { que comanda a seleção dos fatos } \\
\text { é a ordem de importância dos } \\
\text { mesmos no contexto do tema que } \\
\text { está sendo } \\
\text { trabalhado. Há, nesse caso, uma } \\
\text { seleção efetiva dos fatos a partir } \\
\text { dos diversos níveis de análise, } \\
\text { que já se tentou agrupar em } \\
\text { unidades de grandeza, o que } \\
\text { pode ser discutível. }\end{array}$ \\
\hline
\end{tabular}

Fonte: Brasil (2000: 56).

Os $\mathrm{PCN}+$ Ensino Médio explicam que a questão essencial é o espaço geográfico, conceito central da Geografia e que esse espaço se define a partir de uma visão escalar que se apresenta em duas dimensões:

[...] uma cartográfica, que implica o domínio das tecnologias de representação e que, nesse sentido, apresenta uma relação de base matemática; e uma visão em que predomina uma ação seletiva de seus elementos identificados sob o prisma de valores específicos para determinadas visões dos fatos geográficos no todo, constituindo a chamada escala geográfica. Escala é assim a consecução representativa e seletiva do espaço (BRASIL, 2000: 57).

Conforme o texto, um dos principais elementos de compreensão do espaço geográfico é a sua abordagem escalar, sendo imprescindível "dominar o conceito de escala em suas ambas dimensões: a geográfica e a cartográfica". (BRASIL, 2000: 58). Segundo essas diretrizes (BRASIL, 2000: 60),

[...] as competências em Geografia são alinhadas a partir de três perspectivas, que também compõem os agrupamentos nas demais disciplinas da área de Ciências Humanas: 
- representação e comunicação.

- investigação e compreensão.

- contextualização sociocultural.

As competências definidas para a representação e a comunicação em Geografia são:

- Ler, analisar e interpretar os códigos específicos de Geografia (mapas, gráficos, tabelas etc.) considerando-os como elementos de representação de fatos e fenômenos espaciais ou espacializados.

- Reconhecer e aplicar o uso das escalas cartográfica e geográfica como formas de organizar e conhecer a localização, a distribuição e a frequência dos fenômenos naturais e humanos (BRASIL, 2000: 61).

O documento delimita a escala geográfica e a escala cartográfica e defende a necessidade de se conhecer os fundamentos da escala e saber utilizá-la de forma adequada:

No caso da escala cartográfica, quem a manipula deve ter em conta que os fatos a serem representados devem comportar uma dimensão que se adapte tanto às disponibilidades funcionais de espaço para a representação, como e principalmente aos níveis da visão que se pretende obter no processo de representação. Trata-se de uma relação matemática que implica um processo de seletividade dos fatos, na medida em que, utilizar um grande número de fatos diversificados num espaço de representação reduzido também reduz a legibilidade do documento. Além do mais, essa representação escalar deve considerar o ideal do espaço de ocorrência dos fatos a serem representados (BRASIL, 2000: 64).

Conforme a orientação, os procedimentos e os objetivos da Geografia no Ensino Médio podem ser reduzidos a alguns procedimentos básicos, a saber:

- leitura e interpretação dos documentos cartográficos (mapas, gráficos, tabelas), assim como sua elaboração;

- identificação e interpretação das estruturas constituintes do espaço geográfico em suas unidades diversas;

- reconhecimento e identificação dos elementos constitutivos do espaço geográfico, incluindo a avaliação de sua incorporação ao processo de produção/apropriação do espaço geográfico; 
- avaliação de seus impactos, tanto numa perspectiva histórica quanto em relação ao momento presente (BRASIL, 2002: 64).

Os PCNs consideram que "o processo de representação implica também técnicas de registro e de comunicação, envolvendo quantificação, localização espacial e seleção qualificada dos fatos geográficos". Dessa forma, o educando deve elaborar mapas e gráficos, e para tanto deve ter o "domínio das técnicas de elaboração e da leitura desses instrumentos de representação" (BRASIL, 2000: 65).

O documento sugere a organização de eixos temáticos em Geografia para o Ensino Médio, em torno de quatro eixos: i) A dinâmica do espaço geográfico, ii) O mundo em transformação: as questões econômicas e os problemas geopolíticos, iii) $\mathrm{O}$ homem criador de paisagem/modificador do espaço e iv) $\mathrm{O}$ território brasileiro: um espaço globalizado. Cada um dos eixos está dividido em temas e subtemas (ANEXO D).

Para o Ensino Médio, a Cartografia nos PCNs tem, de forma análoga aos PCNs para o Ensino Fundamental, uma valorização como linguagem que procura delimitar a Geografia e seus conceitos estruturantes. Contudo, na estruturação dos eixos, temas e subtemas, o fato de aparecer um item ou outro relacionado à Cartografia, pode levar a uma má interpretação por parte do professor.

Ainda que possa parecer repetitivo, ressaltamos que a Cartografia deveria ser tomada como uma linguagem sistemática de representação da espacialidade em Geografia. Dessa forma, não seria necessário inserir ou pincelar um tópico ou outro entre tantos assuntos. Bastaria definir e deixar explícita a necessidade de possibilitar ao educando a capacidade de representação, bem como a leitura das representações gráficas e cartográficas. Se assim fosse, a valorização da linguagem cartográfica não ficaria apenas na retórica.

O texto dos PCN+ Ensino Médio deixa claro a importância da linguagem da representação gráfica e a necessidade de o aluno saber ler e fazer suas representações. Mas a aparente clareza aponta outros questionamentos: como ele vai aprender? Aprender fazendo? De que forma? Com base na opção de 
que pressupostos? Nada disso fica claro, o que abre a possibilidade de a Cartografia como linguagem ficar apenas no discurso.

\subsection{O Conteúdo Básico Comum: Proposta Curricular do Estado de Minas Gerais}

O processo de formulação da proposta curricular atual do Sistema de Educação do Estado de Minas Gerais ocorre no mesmo contexto de elaboração dos PCNs, ou seja, impulsionados por demandas dos organismos internacionais.

Conforme o Art. 26으 da LDBEN (1996),

Os currículos do ensino fundamental e médio devem ter uma base nacional comum, a ser complementada, em cada sistema de ensino e estabelecimento escolar, por uma parte diversificada, exigida pelas características regionais e locais da sociedade, da cultura, da economia e da clientela.

Dessa forma, aos estados coube a formulação de propostas curriculares que serviriam de base às escolas estaduais, municipais e particulares, situadas em seu território. O Conteúdo Básico Comum (CBC) constitui a proposta curricular da rede estadual de Minas Gerais, que passou a vigorar a partir de 2005.

Nessa proposta, a aplicação dos princípios de produtividade expressa-se na descrição do objetivo de "tornar a rede estadual de ensino de Minas num sistema de alto desempenho" (MINAS GERAIS, 2005: 9). A regra da produtividade também se expressa na checagem final do processo, ou seja, 0 CBC deve ser visto pelos professores como uma referência para os mecanismos de avaliação explicitados em seus objetivos:

A importância dos CBC justifica tomá-los como base para a elaboração da avaliação anual do Programa de Avaliação da Educação Básica (PROEB) e para o Programa de Avaliação da Aprendizagem Escolar (PAAE) e para o estabelecimento de um plano de metas para cada escola. O progresso dos alunos, reconhecido por meio dessas avaliações, constitui a referência básica para 0 estabelecimento de sistema de responsabilização e premiação da escola e de seus servidores. Ao mesmo tempo, a constatação de um domínio cada vez mais satisfatório desses conteúdos pelos alunos gera consequências 
positivas na carreira docente de todo professor (MINAS GERAIS, 2005: 9).

Note-se que os formuladores da proposta explicitam claramente que a avaliação de desempenho do docente $^{30}$ está atrelada ao resultado das avaliações, funcionando até mesmo como mecanismo de coerção e imposição da proposta.

Para Greco (2012: 201),

A regulação das referências de currículo pelos resultados das avaliações às quais está atrelada a avaliação de desempenho dos docentes provoca, por sua vez, grande desconforto entre os docentes [...]. Esse desconforto se deve, sobretudo, ao fato de que eles se sentem como os únicos a serem responsabilizados pela qualidade do ensino, sem que os demais fatores que nela interferem sejam devidamente postos em evidência.

Concepções de Geografia e Cartografia permeiam essa proposta curricular. Em seus textos introdutórios nota-se que, ao explanar sobre o sentido de ensinar Geografia, o texto do CBC destaca o papel das linguagens e da representação gráfica e cartográfica:

Ensinar Geografia tem sentido para o aluno compreender o mundo em que vive e buscar sua transformação, utilizando-se da tecnologia, visando à qualidade de vida ambiental e humana, sendo usuário das linguagens necessárias à interpretação geográfica, com destaque para a visual e, no interior desta, a representação gráfica e cartográfica. Os conhecimentos geográficos o ajudarão a tomar decisões diante de situações concretas, demonstrando sua capacidade de percepção e de estabelecimento de relações com a vida cotidiana, numa perspectiva interdisciplinar (MINAS GERAIS, 2005: 12).

\footnotetext{
${ }^{30}$ A avaliação de desempenho dos professores e a avaliação institucional das escolas são dois dos mecanismos perversos do sistema educacional mineiro. As avaliações são vinculadas aos resultados escolares, sendo definidos centralmente, sem a participação dos professores, os percentuais de alunos que devem ser promovidos e os índices de proficiência a serem alcançados. O governo do Estado instituiu um bônus denominado Prêmio de Produtividade por meio da Lei do Acordo, que condiciona a avaliação de desempenho individual dos professores à melhoria dos resultados escolares. A nota obtida na avaliação de desempenho individual (ADI) define a ocorrência de três situações, segundo a Lei Complementar no 71/03: a) acima de 70\%: progressão na carreira e direito ao Prêmio de Produtividade; b) entre 50\% a 70\%: estagnação na carreira e perda do direito ao Prêmio; c) menos de 50\%: em caso de reincidência, pode vir a ocorrer perda do cargo público (AUGUSTO, 2012).
} 
Conforme o texto do $\mathrm{CBC}$, tendo como referência as Diretrizes Curriculares Nacionais, a proposta de Geografia norteia-se em cinco diretrizes. A primeira diretriz propõe

[...] a valorização e o resgate das práticas socioespaciais, espaçoculturais e ambientais do educando, buscando nelas os referenciais explicativos para a ampliação, aprofundamento e a compreensão do espaço geográfico em mutação (MINAS GERAIS, 2005: 14).

A segunda diretriz diz respeito à construção do conhecimento conforme a metáfora da rede, ou seja, "o educando constrói modelos explicativos da realidade em sua dimensão geográfica, em que ele próprio é integrante da rede dessas aprendizagens relevantes" (MINAS GERAIS, 2005: 15). A terceira diretriz propõe uma nova abordagem dos conteúdos geográficos através de sua organização em um Eixo Integrador, do qual serão desdobrados os eixos temáticos e os temas. A quarta diretriz corresponde ao desafio da transposição didática das três diretrizes anteriores para o cotidiano pedagógico escolar. A quinta diretriz refere-se à avaliação formativa e aos indicadores de competências construídas. As atividades são situações educativas planejadas pelo professor para que as aprendizagens se desenvolvam como processo de construção de conhecimentos.

Segundo a proposta do $\mathrm{CBC}$, a seleção de conteúdos deve levar em conta os critérios científico, tecnológico, cultural e pedagógico. Em relação ao critério pedagógico, em consonância com os PCNs, O CBC também estabelece a divisão dos conteúdos em conceituais, procedimentais e atitudinais. Entre os conteúdos conceituais de Geografia propostos para serem recursivamente trabalhados, destacam- se: o território, o lugar, a paisagem, as redes e a região.

O trabalho pedagógico requer a explicação de alguns princípios e orientações, tais como:

1- A extensão, que se relaciona à escala geográfica, possibilitando distribuição dos fenômenos socioespaciais, e à escala cartográfica, um instrumento de representação e análise do espaço que perpassa todo o trabalho pedagógico; 
2- A temporalidade, que apresenta situações de intensidade e ritmo, deve ser analisada por meio da produção cultural e dos procedimentos matemáticos;

3- A seletividade dos fenômenos recortados da realidade em função da contextualização sociocultural e de sua atratividade. (MINAS GERAIS, 2005: 18).

Entre os conteúdos procedimentais, estabelece-se que "são instrumentos que deverão dotar o aluno de ferramentas de interpretação, análise e representação do espaço que os rodeia, dos territórios, das redes, das regiões." Nesse sentido, a proposta destaca a Cartografia, entre os conteúdos procedimentais: "a interpretação e representação do espaço; o tratamento da informação e a escala temporal, tempo geológico e tempo histórico." (MINAS GERAIS, 2005: 18).

Em relação aos conteúdos atitudinais, O CBC destaca que devem ser priorizadas no cidadão em formação as seguintes atitudes:

Valorização de políticas públicas democratizadoras de acesso à cidadania e à qualidade de vida; respeito à pluralidade cultural expressa nas manifestações de vestir, falar, festejar; consumo com responsabilidade dos recursos naturais não renováveis, evitando o desperdício dos bens pessoais e coletivos; e postura crítica diante do modelo mundial de degradação ambiental (MINAS GERAIS, 2005: 18).

Descritos esses pressupostos, apresentamos-se a seguir a proposta curricular de Geografia do Ensino Fundamental $6^{\circ}$ ao $9^{\circ}$ ano, organizada em eixos temáticos que pressupõe temas para a construção de habilidades. Do Anexo $\mathrm{E}$ constam os quatro eixos temáticos que devem ser contemplados no Ensino Fundamental II ( $6^{\circ}$ ao 9ำ ano) na rede estadual de Educação de Minas Gerais. 


\section{Das orientações do CBC identificamos as seguintes referências à Cartografia, no detalhamento dos tópicos (QUADRO 5):}

\section{QUADRO 5: Tópicos e habilidades relacionados à Cartografia no $\mathrm{CBC}$ para o Ensino Fundamental}

\begin{tabular}{|c|c|c|}
\hline Eixo Temático & $\begin{array}{l}\text { TÓPICOS / } \\
\text { HABILIDADES }\end{array}$ & DETALHAMENTO DAS HABILIDADES \\
\hline \multirow{4}{*}{$\begin{array}{l}\text { Eixo Temático I Tema } \\
\text { 1: Cotidiano de } \\
\text { Convivência, Trabalho e } \\
\text { Lazer }\end{array}$} & $\begin{array}{l}\text { 3. Cidadania e direitos } \\
\text { Sociais }\end{array}$ & $\begin{array}{l}\text { 3.2. Ler e interpretar em mapas, dados e tabelas os avanços dos direitos } \\
\text { sociais no Brasil e no mundo. }\end{array}$ \\
\hline & 6. Redes e circulação & $\begin{array}{l}\text { 6.2. Interpretar gráficos e tabelas que expressem o movimento e a } \\
\text { circulação das pessoas, produtos e ideias no cotidiano urbano. }\end{array}$ \\
\hline & $\begin{array}{l}\text { I. Região e } \\
\text { regionalização }\end{array}$ & $\begin{array}{l}\text { Ler mapas temáticos sabendo extrair deles elementos de comparação e } \\
\text { análise dos aspectos evidenciados no tema estudado. }\end{array}$ \\
\hline & $\begin{array}{l}\text { II. Espaços de } \\
\text { convivência, de } \\
\text { trabalho, de lazer: } \\
\text { cidade e urbanidade }\end{array}$ & $\begin{array}{l}\text { - Interpretar gráficos, fotos e tabelas que expressem fenômenos urbanos } \\
\text { da urbanidade e do entretenimento. }\end{array}$ \\
\hline \multirow{7}{*}{$\begin{array}{l}\text { Eixo Temático II Tema 2: } \\
\text { Patrimônios Ambientais do } \\
\text { Território Brasileiro }\end{array}$} & 9. Sociodiversidade & $\begin{array}{l}\text { 9.3. Identificar em mapas, gráficos e fotos a população brasileira e } \\
\text { mundial, em seu crescimento, tendências e distribuição. }\end{array}$ \\
\hline & $\begin{array}{l}\text { V. Território e } \\
\text { territorialidade }\end{array}$ & $\begin{array}{l}\text { - Identificar as fronteiras culturais do território brasileiro, localizando-as no } \\
\text { mapa. }\end{array}$ \\
\hline & & \\
\hline & & $\begin{array}{l}\text {-Mapear nas formas visíveis e concretas do território usando os processos } \\
\text { históricos construídos em diferentes tempos. }\end{array}$ \\
\hline & $\begin{array}{l}\text { VI. Populações } \\
\text { Tradicionais }\end{array}$ & $\begin{array}{l}\text {-Identificar e localizar no tempo e no espaço a distribuição das populações } \\
\text { tradicionais no território mineiro. }\end{array}$ \\
\hline & $\begin{array}{l}\text { IX. Sítios } \\
\text { arqueológicos }\end{array}$ & $\begin{array}{l}\text {-Descrever as localizações relativas aos sítios arqueológicos tombados } \\
\text { pela Unesco no território brasileiro avaliando sua relevância como } \\
\text { patrimônio a ser preservado. } \\
\text {-Mapear os sítios arqueológicos do território mineiro e avaliar sua } \\
\text { territorialização como atratividade turística. }\end{array}$ \\
\hline & $\begin{array}{l}\text { X. Patrimônio e } \\
\text { Preservação }\end{array}$ & $\begin{array}{l}\text { - Descrever e localizar, no meio urbano e rural do estado de MG, os } \\
\text { aspectos relevantes do regionalismo mineiro manifestado em sua } \\
\text { sociodiversidade }\end{array}$ \\
\hline \multirow{5}{*}{$\begin{array}{l}\text { Eixo Temático III Tema 3: } \\
\text { Redesenhando o Mapa do } \\
\text { Mundo: novas } \\
\text { Regionalizações }\end{array}$} & 15. Fragmentação & $\begin{array}{l}\text { 15.1. Mapear as áreas de exclusão utilizando textos, gráficos, tabelas, } \\
\text { mapas temáticos para analisar as regiões em conflito no mundo. }\end{array}$ \\
\hline & XI. Fronteiras & $\begin{array}{l}\text { - Identificar e mapear as fronteiras políticas, raciais, econômicas, } \\
\text { religiosas, linguísticas, localizando suas territorialidades } \\
\text { desterritorialidades. }\end{array}$ \\
\hline & $\begin{array}{l}\text { XIII. Território e } \\
\text { Redes }\end{array}$ & $\begin{array}{l}\text { - Localizar em fotos os fenômenos da simultaneidade e instantaneidade } \\
\text { das informações e compreender a importância desses recursos no } \\
\text { entendimento das paisagens excluídas ou desterritorializadas e incluídas } \\
\text { ou territorializadas. }\end{array}$ \\
\hline & XIV. Globalização & $\begin{array}{l}\text {-Ler, analisar e interpretar os códigos específicos da Geografia (mapas, } \\
\text { gráficos, tabelas etc.), na representação dos fatos e fenômenos } \\
\text { relacionados à globalização política, econômica, cultural. }\end{array}$ \\
\hline & $\begin{array}{l}\text { XV. Diversidade } \\
\text { Cultural }\end{array}$ & $\begin{array}{l}\text { - Localizar, identificar e descrever os fenômenos relevantes da paisagem } \\
\text { cultural que se expressam no movimento da globalização. }\end{array}$ \\
\hline \multirow{2}{*}{$\begin{array}{l}\text { Eixo Temático IV Tema } 4 \\
\text { : Ambiente, Tecnologia e } \\
\text { Sustentabilidade }\end{array}$} & $\begin{array}{l}\text { XIX. Revolução técnico- } \\
\text { científica }\end{array}$ & $\begin{array}{l}\text { - Interpretar, através de mapas, gráficos e tabelas fenômenos sócio-espaciais } \\
\text { relacionados à revolução tecnocientífica em curso no planeta. }\end{array}$ \\
\hline & XX. Globalização & $\begin{array}{l}\text { - Identificar e localizar, nas múltiplas redes técnicas presentes no município e } \\
\text { no Estado de Minas Gerais, o movimento da globalização. }\end{array}$ \\
\hline
\end{tabular}

Fonte: Minas Gerais (2005). (Adaptado pela autora).

\section{A alfabetização cartográfica deveria ser, na nossa concepção, entendida como um processo que pressupõe a construção das habilidades de leitura e de}


interpretação. Como habilidades a serem construídas do $6^{\circ}$ ao $9^{\circ}$ ano, o CBC destaca a capacidade de ler, interpretar, identificar, reconhecer, mapear, localizar, descrever, analisar e descrever diversos elementos, entre os cartográficos, mapas, gráficos e tabelas.

A leitura da Proposta Curricular de Geografia para o Ensino Médio (ANEXO F) permite identificar as seguintes referências à Cartografia, constantes do Quadro 6:

QUADRO 6: Tópicos e habilidades relacionados à Cartografia no $\mathrm{CBC}$ Ensino Médio

\begin{tabular}{|c|c|c|}
\hline Eixo Temático & $\begin{array}{l}\text { TÓPICOS / } \\
\text { HABILIDADES }\end{array}$ & DETALHAMENTO DAS HABILIDADES \\
\hline $\begin{array}{l}\text { 2: As Novas } \\
\text { Territorialidades no } \\
\text { Campo }\end{array}$ & $\begin{array}{l}\text { 5. Espacialidade rural } \\
5.1 . \quad \text { Reconhecer } \\
\text { fenômenos espaciais que } \\
\text { evidenciam } \\
\text { transformações as } \\
\text { mundo rural. }\end{array}$ & $\begin{array}{l}\text { 5.1.1 Interpretar textos, mapas, gráficos, } \\
\text { imagens, charges e tabelas como formas de } \\
\text { representação dos fenômenos espaciais que } \\
\text { expressam as transformações da vida no } \\
\text { campo. }\end{array}$ \\
\hline \multirow[t]{2}{*}{$\begin{array}{l}\text { Eixo Temático III } \\
\text { Tema 3: A Relação } \\
\text { Sociedade e Natureza } \\
\text { em Questão Mutações } \\
\text { no Mundo Natural }\end{array}$} & $\begin{array}{l}\text { 8. Fontes de energia } \\
8.1 \text {. Compreender os } \\
\text { impasses da sociedade } \\
\text { contemporânea sob a ótica } \\
\text { da produção e do consumo } \\
\text { de energia. }\end{array}$ & $\begin{array}{l}\text { 8.1.1 Comparar dados de mapas temáticos, } \\
\text { gráficos, imagens, textos e tabelas sobre a } \\
\text { atual matriz energética da sociedade industrial } \\
\text { (hidrocarbonetos e gás natural, biomassa, } \\
\text { carvão mineral, álcool etílico, nuclear, } \\
\text { hidráulica, eólica, solar, geotérmica), segundo } \\
\text { os parâmetros da sustentabilidade ambiental. }\end{array}$ \\
\hline & $\begin{array}{l}\text { 11. Domínios de natureza } \\
\text { no Brasil } \\
\text { 11.1. Reconhecer os } \\
\text { domínios de natureza que } \\
\text { compõem o território } \\
\text { brasileiro, avaliando a } \\
\text { interferência humana na } \\
\text { exploração de seus } \\
\text { recursos. }\end{array}$ & $\begin{array}{l}\text { 11.1.2 Interpretar textos, mapas, gráficos e } \\
\text { tabelas que tratam da indústria extrativa } \\
\text { mineral brasileira, segundo sua localização, } \\
\text { empresas, reservas e contribuição no PIB. }\end{array}$ \\
\hline
\end{tabular}

Fonte: Minas Gerais (2005). (Adaptado pela autora).

A Cartografia aparece em dois eixos temáticos no CBC para o ensino Médio. Entendemos que os tópicos e habilidades são apresentados de forma pontual, ou seja, indicando a interpretação comparação e localização de algumas informações geográficas.

A Cartografia deveria estar presente em toda a abordagem, como uma metodologia através da qual se promovesse a aprendizagem geográfica. Dessa forma e como se trata de uma orientação ao trabalho do professor, a abordagem cartográfica nesta etapa estaria aquém das contribuições que os 
conhecimentos cartográficos poderiam agregar ao processo ensino aprendizagem nessa etapa da escolarização.

\subsubsection{Conteúdo Complementar de Geografia}

Os conteúdos complementares que constam na proposta do CBC são conteúdos que se diferenciam pelos conteúdos básicos, esses sim, essenciais e obrigatórios. Dessa forma, os conteúdos complementares devem ser examinados pela equipe de profissionais de cada escola para compor seu projeto de ensino para a disciplina. A leitura e a apreciação das orientações do CBC (ANEXO G) permite identificar as seguintes referências à Cartografia (QUADRO 7), na parte do Conteúdo Complementar de Geografia do Ensino Médio:

QUADRO 7: Tópicos e habilidades relacionados à Cartografia no Conteúdo Complementar de Geografia para o Ensino Médio

\begin{tabular}{|c|c|c|}
\hline Eixo Temático & $\begin{array}{l}\text { TÓPICOS / } \\
\text { HABILIDADES }\end{array}$ & DETALHAMENTO DAS HABILIDADES \\
\hline $\begin{array}{l}\text { V Tema 5: O } \\
\text { Processo de } \\
\text { Urbanização } \\
\text { Contemporâneo: a } \\
\text { Cidade, a Metrópole, o } \\
\text { Trabalho, o Lazer }\end{array}$ & $\begin{array}{l}\text { 18 Gestão da cidade } \\
18.1 \text { Avaliar o crescimento } \\
\text { populacional e suas } \\
\text { implicações na gestão da } \\
\text { cidade nos países centrais e } \\
\text { periféricos. } \\
4.1 \text { Reconhecer na hierarquia } \\
\text { urbana as funções e } \\
\text { centralidades das redes. }\end{array}$ & $\begin{array}{l}\text { 18.1.1 Interpretar a qualidade de vida urbana } \\
\text { em mapas temáticos e textos sobre } \\
\text { saneamento básico, lazer, saúde, energia } \\
\text { elétrica, habitação, avaliando as políticas de } \\
\text { gestão da cidade. }\end{array}$ \\
\hline $\begin{array}{l}\text { VI Tema 6: As Novas } \\
\text { Territorialidades no } \\
\text { Campo }\end{array}$ & $\begin{array}{l}22 \text { Relação campo e cidade } \\
22.1 \text { Reconhecer o significado } \\
\text { da identidade do campo e da } \\
\text { cidade nas sociedades dos } \\
\text { países centrais e periféricos. }\end{array}$ & $\begin{array}{l}\text { 22.1.1 Interpretar materiais imagéticos e } \\
\text { textos sobre aspectos relevantes dos } \\
\text { fenômenos sociais, políticos, econômicos } \\
\text { que tratam da relação campo e cidade. }\end{array}$ \\
\hline $\begin{array}{l}\text { VII Tema 7: A Relação } \\
\text { Sociedade e Natureza } \\
\text { em Questão } \\
\text { Subtemas }\end{array}$ & $\begin{array}{l}\text { 29. Desertificação } \\
29.1 \text { Reconhecer os } \\
\text { processos ecológicos e } \\
\text { antrópicos da desertificação. }\end{array}$ & $\begin{array}{l}\text { 29.1.1 Analisar textos, mapas, gráficos, } \\
\text { tabelas e imagens sobre a desertificação } \\
\text { em processo no Norte de Minas Gerais: } \\
\text { área de abrangência, localização } \\
\text { geográfica, municípios em situação de risco } \\
\text { e suas consequências em âmbito natural, } \\
\text { social, urbano, institucional. } \\
29.1 .2 \text { Analisar textos, mapas, gráficos, } \\
\text { tabelas e imagens sobre a desertificação e } \\
\text { arenização em processo no Brasil. }\end{array}$ \\
\hline $\begin{array}{l}\text { VII Tema 8: As Novas } \\
\text { Fronteiras do } \\
\text { Capitalismo Global: os } \\
\text { Territórios nas Novas } \\
\text { Regionalizações } \\
\end{array}$ & $\begin{array}{l}31 \text { Terceiro Setor } \\
31.1 \quad \text { Reconhecer a } \\
\text { importância do terceiro setor e } \\
\text { os projetos de inclusão social } \\
\text { nos países periféricos. }\end{array}$ & $\begin{array}{l}31.1 .1 \text { Interpretar textos, mapas, tabelas e } \\
\text { gráficos como portadores de informação de } \\
\text { tipos de organização, frequência, } \\
\text { distribuição e localização do Terceiro Setor } \\
\text { no Brasil e no mundo. }\end{array}$ \\
\hline
\end{tabular}

Fonte: Minas Gerais (2005). (Adaptado pela autora). 
Seja para o Ensino Fundamental II, seja para o Ensino Médio, o CBC é considerado de forma análoga aos PCNs. Contudo, a leitura dos quadros permite identificar uma ênfase na localização dos fenômenos em detrimento da análise, reflexão e interpretação de tais fenômenos como parte integrante dos estudos em Geografia.

Uma reformulação necessária nessa proposta seria a construção de uma abordagem, de uma explanação, de um ponto de consenso, fortemente calcados na importância da capacidade de leitura, construção, análise e interpretação da representação cartográfica no processo educativo, que envolvesse não apenas a Geografia, mas também disciplinas como a Matemática e a Arte.

Essa abordagem deveria estabelecer que o trabalho com a linguagem da representação gráfica seja visto como procedimento comum no trabalho com mapas e com outras representações, em todos os temas de caráter espacial. Tal procedimento constituiria uma contribuição fundamental para a aprendizagem do raciocínio geográfico dos educandos.

Essa reformulação deveria opor-se ao que se verifica na prática escolar, em que, geralmente, a Cartografia é estudada como uma unidade ou um conteúdo do ano letivo de determinada série, desconsiderando o potencial da Cartografia como uma metodologia de aquisição de conhecimento, não só de Geografia, mas também, de outras disciplinas.

Oliveira (1978: 15) afirmou que "o problema didático do mapa é que, em nível de sala de aula, o professor o utiliza como um recurso visual, com o objetivo de ilustrar e mesmo 'concretizar' a realidade" apresentando-o como um elemento estático e sem vida. Como transformar os mapas em figuras dinâmicas e "com vida"? Certamente sabemos que a Cartografia dispõe de métodos de representação para isso. Para que essa "vida" aflore, entendemos uma correta 
construção dos mapas que atenda à gramática ${ }^{31}$ e à linguagem de sua representação gráfica.

Uma reflexão sobre a Cartografia nas orientações curriculares como os PCNs e o CBC, faz ressaltar que esses dois currículos, são denominados currículos prescritos. Como tal, são a base da avaliação dos alunos e, consequentemente, do trabalho dos professores. Por outro lado, é importante lembrar que o currículo em ação nas escolas não é uma mera reprodução do currículo prescrito, oficial, elaborado em diferentes instâncias. Cada professor reelabora, ressignifica tais orientações de acordo com suas experiências, pela interação com os colegas, mediados pelas condições de trabalho, valendo-se de diversas referências e de seus diversos saberes.

Dessa forma, ressaltando-se algumas impropriedades nas orientações curriculares oficiais para a Geografia, e que se referem à Cartografia, visualizamos ainda mais a necessidade de repensarmos a formação docente, para constituir uma formação que conceda ao professor autonomia e confiança na abordagem das diversas temáticas. Em referência à Cartografia, as orientações curriculares para os ensinos Fundamental e Médio são permeadas por concepções diversas, de certo modo, confusas que impossibilitam um trabalho que contribua para o raciocínio geográfico dos alunos.

Tais transformações no campo educacional são decorrentes da reestruturação e da manutenção da ordem capitalista em escala mundial. Especialmente no Brasil, quando se refere à questão curricular, é necessário considerar o contexto político em que deram as reformas curriculares que afetaram os sistemas educativos nos últimos anos. As propostas curriculares que orientam a educação brasileira na atualidade foram gestadas em um momento político em que sobressaiu a lógica do custo-benefício.

Dessa forma, as transformações no campo da educação têm uma relação direta com a proposição de currículos como os Parâmetros Curriculares

\footnotetext{
${ }^{31}$ Estrutura e arranjo dos signos que dão legibilidade ao mapa: título, fonte, orientação, projeção cartográfica, escala, legenda, à semelhança da gramática de uma língua falada ou escrita (português, francês, etc.).
} 
Nacionais e a reestruturação da formação docente decorrente das Diretrizes Curriculares Nacionais do Ministério da Educação para a Licenciatura. Esses documentos trazem concepções sobre a Cartografia que, em muitos aspectos, destoam da tendência de abordagem da Cartografia como linguagem capaz de apropriar o conhecimento geográfico. 


\section{A CARTOGRAFIA NA FORMAÇÃO DO PROFESSOR DE GEOGRAFIA}

\begin{abstract}
O estudo da Geografia era um dos campos de conhecimentos dos savants, pois a cultura letrada da época, de viés enciclopédico, abrangia várias áreas, passando pela literatura, ciências, poética, artes ou história. Naquele tempo, um dos espelhos da erudição de um letrado era seu domínio sobre o espaço onde desenrola-se 'o teatro do mundo'. Esse tipo de conhecimento não era inerente somente aos embaixadores, mas, também, a príncipes, nobres, eruditos e homens de letras que deveriam se mostrar sensíveis ao estudo, pois o domínio da Geografia fazia parte de uma educação polida.
\end{abstract}

Júnia Ferreira Furtado

A epígrafe desta seção faz referência aos conhecimentos geográficos nos tempos imperiais. Conforme a citação, entendemos que naquela época tais conhecimentos eram muito valorizados pelas diversas esferas da nobreza, por constituir um instrumento para estratégias de dominação do espaço.

Ensinar Geografia nos dias de hoje compreende uma instância de importância peculiar. O papel da Geografia na escola assume novos contornos. Milton Santos nos ajuda a valorizar o ensino da Geografia Escolar, do ponto de vista social, principalmente num tempo em que o capital global e o estilo de vida da sociedade contemporânea tentam reduzir o papel do cidadão ao de mero consumidor:

Quando se confundem cidadão e consumidor, a educação, a moradia, a saúde, o lazer aparecem como conquistas pessoais e não como direitos sociais. Até mesmo a política passa a ser uma função do consumo. Essa segunda natureza vai tomando lugar sempre maior em cada indivíduo, o lugar do cidadão vai ficando menor, e até mesmo a vontade de se tornar cidadão por inteiro se reduz (SANTOS, 2007: 155).

$\mathrm{Na}$ perspectiva de Milton Santos, a educação pode estar alinhada aos propósitos utilitaristas do mercado, ou firmar um compromisso com os interesses das classes populares. Antes de discutir especificamente a 
formação de professores de Geografia, apresentamos uma abordagem sobre as reformas curriculares que afetam diretamente a formação desses professores. Pensamos que, para compreender um pouco mais sobre essas políticas educacionais e sua influência nas conformações dos currículos, especialmente, no da licenciatura em Geografia, é necessário tecer algumas considerações a respeito de tais políticas.

\subsection{As reformas curriculares no contexto educacional brasileiro}

$\mathrm{Na}$ atualidade, observamos um movimento de transformações educativas, atribuído a uma lógica reguladora de caráter mercantil. Percebe-se que tal lógica tem sido apropriada tanto nos discursos, como nas práticas dos agentes escolares. As transformações educativas impõem, por sua vez, a necessidade de mudanças em diversas ordens, especialmente em relação ao trabalho docente.

As regulações da Educação implicam uma verdadeira reestruturação do trabalho do professor, como mostram Borges e Oliveira (2006: 136):

A escola atual é confrontada com forças contraditórias oriundas dos níveis locais (comunidade, grupos de pressão, associações diversas, etc.), nacionais (Estado, indústrias, sindicatos, etc.) e transnacionais (globalização, regulação, competição, estandardização, mobilidade, etc.). Estas pressões se conjugam por meio de processos de reformas educacionais, que expressam grandes contradições: igualdade e competição, desempenho individual e ênfase no trabalho coletivo, profissionalização e controle externo, novas demandas e compressão de recursos, ênfase na qualidade dos processos e visão quantitativa dos resultados, entre outras.

Essas regulações externas tornam a esfera de atuação dos professores um campo extremamente complexo. Os constantes movimentos de reforma tornam-no ainda mais instável e passível de mudanças.

A partir dos anos 1990, o movimento de reformas educacionais trouxe consequências significativas para a organização e a gestão escolares, que representaram uma verdadeira alteração da natureza e da definição do trabalho docente (OLIVEIRA, 2007). O que temos observado, é que no interior, e a reboque desse processo maior, ocorre um processo de desvalorização e de 
precarização do trabalho docente, que passa a ser visto como apenas mais um insumo "na linha de montagem".

O Brasil e outros países da América Latina, tomadores de empréstimos dos organismos financeiros internacionais, passaram por reformas educacionais nas últimas décadas. Uma importante característica dessas reformas é o seu forte caráter político e econômico, em que os critérios de justiça social ora cedem, ora mesclam-se ou confundem-se com os princípios da eficácia econômica.

Oliveira (2007: 100) destaca que

Essas reformas revelam uma contradição expressa entre a tentativa de adequação e ajuste dos sistemas públicos e a educação às exigências atuais do desenvolvimento capitalista e as demandas por maior acesso à educação, à cultura, ao reconhecimento à diferença. [...] em muitos casos, tais reformas têm sido orientadas para contenção e cortes nos gastos públicos, ensejando políticas sociais focalizadas em seguimentos específicos, em detrimento de direitos universais [...].

Uma opção para se compreender as reformas educacionais é o enfoque histórico, o qual permite observar que tais reformas inserem-se no âmbito maior de reforma do aparelho do Estado imposto a diversos países. Esse movimento faz parte de uma estratégia orientada por organismos internacionais como o Fundo Monetário Internacional (FMI) ${ }^{32}$ e o Banco Mundial (BM) como forma de enfrentamento da crise do capitalismo, a partir dos anos 1970.

Sob esse aspecto, o sociólogo Boaventura de Souza Santos, comenta que, a esmagadora maioria dos países do Sul não conseguiu beneficiar-se das transformações da economia mundial. A situação de colapso que atingiu os países manifesta-se de múltiplas formas, dentre as quais "a perda da pouca soberania efetiva dos Estados periféricos, que ficaram mais e mais sujeitos aos

\footnotetext{
${ }^{32}$ Fonseca (1995) explica que o FMl é o órgão que tem o papel de coordenar as políticas de desenvolvimento e de promover a estabilidade da balança de pagamentos dos paísesmembros, enquanto o Banco Internacional de Reconstrução e Desenvolvimento ou Banco Mundial (BIRD) funciona como um fundo capaz de catalisar financiamentos externos para o desenvolvimento de projetos prioritários junto aos países membros. Os empréstimos são definidos em estreita colaboração com o FMI, e são uma condição para concessão de créditos junto ao BIRD.
} 
programas de ajustamento estrutural do Banco Mundial e FMl", destaca Santos (2000: 293).

No Brasil, especialmente a partir do governo Fernando Henrique Cardoso, as reformas estiveram vinculadas a interesses econômicos, entre os quais o financiamento da dívida externa. Uma pré-condição desse financiamento seria a implementação de reformas em diversos âmbitos, entre eles na Educação, vista pelo Banco Mundial como uma medida compensatória importante para a contenção demográfica e para o aumento da produtividade das populações mais carentes (ALTMANN, 2002).

O pacote de reformas educativas proposto pelo BIRD determinava, segundo Torres $^{33}$ (1996 apud ALTMANN, 2002: 80),

a) Prioridade depositada sobre a educação básica.

b) Melhoria da qualidade (e da eficácia) da educação como eixo da reforma educativa. A qualidade localiza-se nos resultados e esses se verificam no rendimento escolar. Os fatores determinantes de um aprendizado efetivo são, em ordem de prioridade: bibliotecas, tempo de instrução, tarefas de casa, livros didáticos, conhecimentos e experiência do professor, laboratórios, salário do professor, tamanho da classe. Levando-se em conta os custos e benefícios desses investimentos, o BIRD recomenda investir prioritariamente no aumento do tempo de instrução, na oferta de livros didáticos (os quais são vistos como a expressão operativa do currículo e cuja produção e distribuição devem ser deixadas ao setor privado) e no melhoramento do conhecimento dos professores (privilegiando a formação em serviço em detrimento da formação inicial).

c) Prioridade sobre os aspectos financeiros e administrativos da reforma educativa, dentre os quais assume grande importância a descentralização.

d) Descentralização e instituições escolares autônomas e responsáveis por seus resultados. Os governos devem manter centralizadas apenas quatro funções: (1) fixar padrões; (2) facilitar os insumos que influenciam o rendimento escolar; (3) adotar estratégias flexíveis para aquisição e uso de tais insumos e (4) monitorar o desempenho escolar.

\footnotetext{
${ }^{33}$ TORRES, Rosa Maria. Melhorar a qualidade da educação básica? As estratégias do Banco Mundial. In: TOMMASI, L. De; WARDE, J. M.; HADDAD, S. (Orgs.). O Banco Mundial e as políticas educacionais. São Paulo: Cortez Ed./Ação Educativa/PUC-SP, 1996. p. 125-194.
} 
e) Convocação para uma maior participação dos pais e da comunidade nos assuntos escolares.

f) Impulso para o setor privado e organismos não governamentais como agentes ativos no terreno educativo, tanto nas decisões como na implementação.

g) Mobilização e alocação eficaz de recursos adicionais para a educação como temas principais do diálogo e da negociação com os governos.

h) Um enfoque setorial.

i) Definição de políticas e estratégias baseadas na análise econômica.

Esse pacote de medidas é permeado por uma lógica de custo-benefício que vincula a Educação à produtividade ${ }^{34}$.

Para Frigotto (1995: 85),

[...] a perspectiva neoliberal é de uma educação regulada pelo caráter unidimensional do mercado [...] de onde resulta uma filosofia utilitarista e imediatista e uma concepção fragmentária do conhecimento, concebido como um dado, uma mercadoria e não como uma construção, um processo.

No processo corrente de mandos e desmandos externos, em 1996, ocorreu no Brasil a promulgação da LDB, fruto de, pelo menos vinte $\operatorname{anos}^{35}$ de discussão e, concomitante, ao movimento maior de regulação educativa centrada na racionalidade econômica e na eficiência administrativa. Inicia-se assim a elaboração do projeto que resultará na Lei 9394/96. Ao longo desse período, após "negociações de várias ordens, obteve-se um texto com pouca incoerência e muitas controvérsias", sendo que entre as diversas interpretações da Lei há "as que o consideram polissêmico, resultando de

\footnotetext{
${ }^{34}$ Fonseca (1995) conclui que os efeitos dos projetos do BIRD no setor educacional teriam uma reduzida eficácia, com efeitos pouco significativos. Por isso, questionava-se, naquele período, a real necessidade de financiamento externo à educação brasileira, visto que "algumas ações decorrentes dos acordos poderiam ser perfeitamente desenvolvidas com a parte nacional dos recursos" (FONSECA, 1995:192). A autora considera ainda a questão da inadequação do financiamento do BIRD, apontando o formalismo dos acordos, suas condicionalidades políticas e econômicas como fatores que provocariam "incompatibilidades de ordem administrativa e financeira em seu confronto com a organização local" (FONSECA, 1995:193).

35 É no processo constituinte de 1986, após 21 anos de autoritarismo, no afã de democratização da sociedade, que toma corpo a discussão sobre os novos rumos da Educação Brasileira.
} 
muitas vozes, até as que o tomam como uma costura de partes de diferentes corpos, recuperando a noção organicista, ou como mosaico" (OLIVEIRA, 2007: 99).

O texto da LDB reflete essa nova regulação educativa apoiada em três eixos: gestão, financiamento e avaliação (OLIVEIRA, 2007), sendo assim convergente à proposta de reforma do Banco Mundial, com assimilação de seus elementos norteadores. A escola passa a ser o núcleo do planejamento, cuja gestão democrática deve incluir a participação da comunidade, como demonstra 0 Projeto Amigos da Escola ${ }^{36}$ e o Dia da Família na Escola (24 de abril) ${ }^{37}$ (ALTMANN, 2002), reduzindo assim o papel social do Estado na Educação.

Sobre o financiamento, a lógica da eficiência econômica incide na consideração per capita dos gastos. O financiamento passa a contar com mecanismos como o Fundo de Manutenção e Desenvolvimento do Ensino Fundamental e de Valorização do Magistério (FUNDEF) e, posteriormente, o Fundo de Manutenção e Desenvolvimento da Educação Básica (FUNBEB).

Yanaguita (2013) discutiu o financiamento da educação no Brasil no período de 1990-2010 com vistas a entender os impactos no padrão de gestão do ensino fundamental. Para Yanaguita, as mudanças legais nas políticas de financiamento da educação básica configuraram-se como estratégia dos

\footnotetext{
${ }^{36}$ O Projeto Amigos da Escola tem o objetivo de contribuir com o fortalecimento da escola pública de educação básica por meio do trabalho voluntário e da ação solidária. O projeto é implementado em parceria com a Petrobras, o Instituto Faça Parte, o Conselho Nacional de Secretários de Educação (Consed), a união Nacional dos Dirigentes Municipais de Educação (Undime), além de instituições e empresas comprometidas com a educação de qualidade para todos. O Amigos da Escola incentiva a participação de voluntários no desenvolvimento de ações e de projetos educativos e de cidadania realizados em beneficio da escola e da comunidade.

Disponível $<$ http://www.seduc.mt.gov.br/conteudo.php?sid=478\&parent=475>. Acesso em 09 abr. 2014.

${ }^{37}$ O Dia da Família na Escola foi instituído oficialmente, pelo Ministério da Educação e Cultura (MEC). O "Dia Nacional da Família na Escola", a ser comemorado no País todo no dia 24 de abril tem como lema: "Um dia para você dividir responsabilidades e somar esforços". Será realizado oficialmente duas vezes ao ano, como estratégia de reforço à importante presença da família na escola, com o objetivo de discutir o rendimento escolar do filho e a própria administração escolar. Trata-se de um instrumento simbólico que tem a finalidade de aproximar e integrar a comunidade à escola. O Dia Nacional da Família na Escola não é uma ação isolada; faz parte de um conjunto de atos previstos no próprio Regimento Escolar, quando trata, especialmente, do Conselho de Escola, sua instância maior de decisões, em que a presença dos pais ou da Associação de Pais e Mestres é obrigatória.
} 
bancos multilaterais para que as mudanças mercadológicas, planejadas em suas agendas, viessem a estabelecer-se nos países subdesenvolvidos. A partir dos novos mecanismos de financiamento, que supostamente regulamentariam e viabilizariam a descentralização financeira, houve uma redução da responsabilidade social do Estado. Além disso, houve uma indicação também do autofinanciamento, nesse caso, por meio do trabalho voluntário.

Na prática, ocorre

[...] contenção dos gastos com a educação pública, priorizando, mesmo assim avaramente, o ensino fundamental, lançando o ensino médio e o superior à arena da privatização, além de fazer jorrar suas graças financeiras pelos cofres das empresas privadas de ensino superior (JIMENEZ; MENDES SEGUNDO, 2007: 125).

Quanto à avaliação, a LDB obriga a regularidade e a ampliação dos exames nacionais e as avaliações institucionais (OLIVEIRA, 2007).

Conforme o Art. 9 da LDB, parágrafo VI, é de responsabilidade de União

- assegurar processo nacional de avaliação do rendimento escolar no ensino fundamental, médio e superior, em colaboração com os sistemas de ensino, objetivando a definição de prioridades e a melhoria da qualidade do ensino.

Das exigências do Banco Mundial decorrem os diversos sistemas de avaliação implementados na década de 1990, como o Sistema Nacional de Avaliação da Educação Básica (SAEB), o Exame Nacional de Ensino Médio (ENEM) para avaliar a Educação Básica, e o Exame Nacional de Cursos (ENADE), para a avaliação dos cursos superiores (ALTMANN, 2002). A qualidade da educação é, dessa forma, compreendida como passível de ser medida por resultados, ou seja, por números. Seguindo à risca as prerrogativas e as propostas do Banco Mundial, constata-se que

[...] a educação passou a ser analisada com critérios próprios do mercado, e a escola é comparada a uma empresa. As propostas do BIRD para a educação são feitas basicamente por economistas, dentro da lógica e da análise econômica. A relação custo-benefício e a taxa de retorno constituem as categorias centrais, com base nas quais se define a tarefa educativa, as prioridades de investimento, os rendimentos e a própria qualidade (ALTMANN, 2002: 86). 
Nesse projeto de mercantilização da educação (LEHER, 1998) ${ }^{38}$, a concepção de educação restringir-se-ia ao papel de reproduzir a força de trabalho para o capital e formar ideologicamente - conforme os interesses do projeto - e servir como segmento do mercado a ser explorado comercialmente pelo setor privado.

Dessa forma, o projeto de mercantilização

[...] vem demandando uma educação capaz de conformar o 'novo homem' de acordo com os pressupostos técnicos, psicológicos, emocionais, morais e ético, políticos da 'flexibilização' do trabalho e com um modelo de cidadania que não interfira nas relações burguesas fundamentais no contexto de ampliação da participação política (FALLEIROS, 2005: 211).

Observa Martins (1999) que a orientação neoliberal "encontrou em Minas Gerais, especialmente no campo educacional, um importante espaço de experimentação e implementação".

Em 1994, foi aprovado pelo Banco Mundial (BM) um empréstimo de 150 milhões de dólares para o projeto "Melhoria da Qualidade da Educação Básica em Minas Gerais" (Pró-Qualidade). O Pró-Qualidade firmou-se como padrão de referência do $\mathrm{BM}$, tal o nível de adesão do governo mineiro às suas orientações (TOMMASI, 1998). Durante o governo de Eduardo Azeredo, foram implantadas dezenas de subprogramas do Pró-Qualidade.

As reformas educacionais em Minas Gerais trouxeram grandes dificuldades aos professores, visto que:

[...] o diálogo entre as referências curriculares de âmbito federal, estadual e local tenciona os professores, supervisores, gestores, atinge também os alunos e, de certo modo, os pais de alunos [...]. A quantidade de documentos curriculares oficiais, as constantes mudanças impostas às instituições de ensino, as alterações em dispositivos e normas são alguns dos fatores que podem dificultar a disposição do professor a ter acesso aos documentos curriculares, fruto desses dispositivos legais e das orientações. Acrescente-se que há tensões e dificuldades na relação entre as referências curriculares oficiais

${ }^{38}$ Mais leituras sobre o projeto de mercantilização da Educação podem ser encontradas em LEHER, Roberto. Da ideologia do desenvolvimento à Ideologia da Globalização: a Educação como Estratégia do Banco Mundial para o "Alívio" da Pobreza. 1998. Tese (Doutorado), FEUSP, 1998, considerado referência em estudos dessa temática. 
mais gerais e aquelas que representam os princípios que estruturam e fundamentam as disciplinas de referência pelas quais os docentes respondem na educação escolar (GRECO, 2012: 27).

Para Frigotto (1995), a "possibilidade de construção de alternativas democráticas e socialistas implica, necessariamente, um esforço sistemático de compreensão crítica da crise do capitalismo". Assim, do ponto de vista analítico, é importante situar essas questões, quando se aborda o currículo. Contudo, o tratamento da temática das reformas educacionais merece um espaço mais amplo, o qual não se dispõe neste trabalho, haja vista seus objetivos. Dessa forma, demais aprofundamentos podem ser encontrados em Gentili (1995), Leher (1998).

Entretanto, não podemos esquecer que

[...] a ideologia neoliberal defende uma escola que se constitua em efetivo instrumento de controle social e se paute por qualidade e produtividade, características essas definidas com base no resultado educacional obtido e estabelecidas por meio de padrões, indicadores e medidas. Daí a preocupação tanto com a proposição de um currículo nacional, ou segundo, o eufemismo preferido entre nós, de Parâmetros Curriculares Nacionais (PCN), como a criação de um sistema de avaliação de desempenho das escolas. Ambos são vistos como essenciais para o alcance de qualidade em educação (MOREIRA, 1997: 94).

Para fazer frente às consequências de tais imposições externas na Educação brasileira, é preciso reconhecer essa instância como um processo, no qual se desenvolvem múltiplas dimensões do humano. Nesse sentido, Frigotto (1995: 105) afirma que

A escola pública, unitária, numa perspectiva de formação omnilateral e politécnica, levando em conta as múltiplas necessidades do ser humano é o horizonte adequado, ao (sic) nosso ver, do papel da educação na alternativa democrática ao neoliberalismo.

Por essa razão, afirma Greco (2012: 202):

[...] os docentes não têm tido oportunidades de adquirir uma compreensão mais ampla das reformas educacionais, das políticas de educação e das mudanças profundas que 
envolvem os currículos, a ponto de poderem situar mais criticamente suas práticas.

É necessário que o universo escolar seja o lócus do despertar da consciência e da formação de um cidadão e, não de um consumidor. Nesse sentido, refletir sobre o processo histórico de constituição dos currículos pode ser uma arma de luta para os professores.

\subsection{Reformas curriculares e a formação docente}

A formação de professores no Brasil deve ser analisada em consonância à estruturação política e econômica no país. Gatti et al. (2010) discutiram a formação de professores no Brasil, considerando a realidade expressa nos projetos político-pedagógicos de alguns cursos de licenciatura específicos. Em suas análises, os autores constatam que a demanda de professores começa a crescer com a expansão das redes públicas de ensino, o que ocorre em vista do ritmo acelerado das demandas da expansão industrial e do capital principalmente a partir dos anos 1960.

Gatti et al. (2010: 96) mostram que a oferta de cursos normais e de diversas licenciaturas em 1970 e 1980 fez-se sem maiores discussões, segundo os modelos instituídos no século XIX e início do século XX:

A formação de professores no país atualmente ainda sofre, primeiro, os impactos do crescimento rápido das redes públicas e privada de Ensino Fundamental, e das improvisações que foram necessárias para que as escolas funcionassem, o que criou a representação que formar professor pode ser um processo rápido e aligeirado. $E$ segundo, das consequências advindas da adoção do modelo chamado $3+1$ : bacharelado em área disciplinar mais apenas um ano de formação em educação para obtenção de licenciatura, o que permitiria ao profissional lecionar nas escolas.

Dessa maneira, a formação docente esteve, durante muito tempo, centrada num perfil profissional fundamentado no conhecimento disciplinar específico, em detrimento da formação de um professor para a educação básica, que trabalharia com crianças e adolescentes em formação.

A formação de professores, no Brasil, tem como divisor de águas a Lei 9394/96, sancionada em 20 de dezembro de 1996, que estabelece as 
Diretrizes e Bases da Educação Nacional (LDBEN). A formação de professores, antes dessa Lei, baseava-se no modelo chamado $3+1$ : Bacharelado em área disciplinar mais apenas um ano de formação em educação para obtenção de Licenciatura. Esse modelo tinha como consequência a sedimentação da concepção de que o exercício do professor estaria ligado à vocação, o que "retirava dos cursos formadores a responsabilidade de formar o professor" (LEÃO, 2008: 27).

A Lei 9394/96 trouxe avanços para a educação brasileira (SOARES, 2007), entre os quais, os sistemas de avaliação do ensino básico que, com a LDBEN, passaram a constituir-se instrumentos de verificação dos direitos dos alunos.

No Art. 9, inciso 6 da LDBEN estabelece-se como função da União

[...] assegurar o processo nacional de avaliação do rendimento escolar no ensino fundamental, médio e superior, em colaboração com os sistemas de ensino, objetivando a definição de prioridades e a melhoria da qualidade do ensino.

A avaliação permitiu conhecer que, há no Brasil, uma urgência educacional. Ao mesmo tempo, muitos educadores consideram que a avaliação é uma forma de opressão dos docentes.

No tocante à formação de professores para a Educação Básica, a LDBEN também trouxe inovações. A primeira inovação foi o reconhecimento da especificidade do curso de Licenciatura, além do fato de que, a partir da lei, os cursos para formação de professores passaram a ser oferecidos predominantemente em nível superior.

Conforme o Parecer CNE/CP 28/2001:

A licenciatura é uma licença, ou seja, trata-se de uma autorização, permissão ou concessão dada por uma autoridade pública competente para o exercício de uma atividade profissional, em conformidade com a Legislação. [...]. O diploma de licenciado pelo ensino superior é o documento oficial que atesta a concessão de uma licença. No caso em questão, trata-se de um título acadêmico obtido em curso superior que faculta ao seu portador o exercício do magistério na educação básica dos sistemas de ensino, respeitadas as 
formas de ingresso, o regime jurídico do serviço público ou a Consolidação das Leis do Trabalho (CLT) (BRASIL, 2001: 2).

A Resolução CNE/CP 1/2002 "institui Diretrizes Curriculares Nacionais para a formação de Professores da Educação Básica, em nível superior, curso de Licenciatura, de graduação plena" ${ }^{39}$, e a Resolução CNE/CP 2/2002 "institui a duração e a carga horária dos cursos de licenciatura, de graduação plena, de formação de professores da Educação Básica em nível superior".

Os pareceres e as duas resoluções "são basilares no que se refere à regulação institucional dos projetos pedagógicos dos cursos de Licenciatura" (SOUZA, 2007: 30). O autor destaca os elementos inovadores que essa normatização produziu, a ponto de se caracterizar uma mudança de paradigma na formação de professores:

- a proposta resultou de amplo debate com representantes de grande número de entidades ligadas à Educação escolar;

- houve uma preocupação com a profissionalização da docência, vista como algo que exige mais que a posse de um dom ou a entrega pessoal a uma vocação;

- a licenciatura plena deixou de ser apêndice e adquiriu identidade frente ao bacharelado, exigindo um projeto políticopedagógico específico, com percurso próprio, terminalidade e titulação definidos, rompendo com o tradicional modelo de formação de professores, que ficou amplamente conhecido 'como modelo 3+1';

- houve uma nova concepção de educação básica, ampliada para além do primário e do fundamental;

- houve uma ampliação do tempo destinado às atividades práticas, entendidas como importante dimensão formativa dos futuros docentes;

- houve uma enorme preocupação com a formação das competências, que passam a ser orientadoras da seleção e ordenamento de conteúdos de diferentes âmbitos de conhecimento profissional. (SOUZA, 2007: 30)

Como decorrência do Parecer CNE/CP 28/2001 e da Resolução CNE/CP 2/2002 houve uma ampla discussão sobre a duração e a carga horária dos

\footnotetext{
${ }^{39}$ As diretrizes têm o objetivo de referenciar os cursos de Licenciatura na elaboração das propostas pedagógicas e curriculares e foram criadas com o objetivo de conferir identidade profissional aos futuros professores por meio da elaboração de uma matriz curricular própria para esse fim: formar professores.
} 
cursos de Licenciatura, da nova concepção e das diretrizes da dimensão prática da formação dos futuros professores e da regulamentação do estágio curricular supervisionado.

A instituição desses instrumentos legais ainda está em processo de efetuar uma real alteração na formação de professores, principalmente naqueles cursos em que se verifica a subordinação da licenciatura à lógica do bacharelado, conforme observa Leão (2008), quando discute a influência das Diretrizes Curriculares Nacionais do Ministério da Educação e Cultura para a formação de professores de Geografia da Educação Básica em nível superior.

As Diretrizes Curriculares Nacionais do Ministério da Educação (DCNs/MEC) foram criadas pela Resolução CNE/CP 02, de 19 de fevereiro de 2002, que instituiu a duração e a carga horária dos cursos de licenciatura, de graduação plena e de formação de professores da Educação Básica em nível superior. Tais diretrizes apontam problemas existentes na formação dos professores e criam orientações para referenciar os cursos de licenciatura na elaboração de suas propostas pedagógicas e curriculares.

De maneira geral, as Diretrizes Curriculares Nacionais para os cursos de Licenciatura são amplas, ficando a estruturação do currículo a cargo de cada instituição. Zuba (2013) entende que tais diretrizes impulsionaram algumas mudanças na formação do profissional licenciado em Geografia.

Ao discutir as reformulações do Projeto Político-pedagógico do curso de Geografia da Universidade Estadual de Montes Claros, em decorrência das Diretrizes, Zuba (2013) demonstra que houve um aumento significativo da carga teórica e prática da Disciplina Prática de Ensino e Estágio Supervisionado, instâncias nas quais poderia também haver espaço para abordar o que é Cartografia, e como seu ensino pode servir de instrumental à Geografia. Contudo, apenas a ampliação da carga horária de prática de ensino não seria suficiente para alcançar a terminalidade própria da Licenciatura nos cursos de formação de professores, pois a formação dos graduandos, centrada na lógica do Bacharelado, reforça a ênfase no saber técnico e especializado. Essa atitude conduz à fragmentação e à verticalização do conhecimento. $O$ 
resultado é a formação de profissionais despreparados, e os reflexos manifestam-se na escola básica.

$\mathrm{Na}$ organização dos cursos de Licenciatura em Geografia predominam a lógica do mercado e do bacharelado. A lógica do bacharelado explicar-se-ia, pois nos cursos de Licenciatura "em seus moldes tradicionais, a ênfase está contida na formação dos conteúdos de área, onde o bacharelado surge como opção natural que possibilitaria, como apêndice, também o diploma de licenciado" (LEÃO, 2008: 28).

Entre outros problemas, nos cursos de Licenciatura em Geografia, também se observa "a deficiência na interlocução da Geografia acadêmica com a Geografia Escolar que afeta a construção do conhecimento geográfico" (LEÃO, 2008: 17). Leão (2008) aponta também que os graduandos apresentam deficiência em relação à compreensão da Geografia enquanto ciência.

Em seu estudo, Leão (2008) aponta que a "terminalidade e integralidade própria" da Licenciatura não ocorrem na prática, permanecendo, ainda, apenas no texto que deu origem às DCNs do MEC. Apesar das orientações legais, na prática, a Licenciatura ainda deixa a desejar na formação de um professor de Geografia que deverá trabalhar o ensino da espacialidade (incluindo a representação gráfica dessa espacialidade) para crianças e jovens nas escolas de Educação Básica.

Outra questão importante sobre a formação docente refere-se à questão da identidade dos professores atuantes no Ensino superior: os professores formadores. Há uma recorrente falta de identidade desses professores com o curso e com o que propõem a formar, a saber, professores que irão atuar na Educação básica.

A propósito, em relação à Cartografia, nosso foco de maior interesse na formação do professor de Geografia, Leão (2008) afirma que sua abordagem está aquém de suas potencialidades, posto que encontra-se isolada nas matrizes curriculares. Essa compartimentação do saber certamente influencia a forma como a Cartografia é apresentada aos licenciandos ao longo da 
graduação e, da mesma forma, traz consequências para a concepção de Cartografia que o professor constrói, o que tem repercutido diretamente na forma como se ensina nas diversas etapas do Ensino Fundamental e Médio.

Uma parte dessa Cartografia pouco producente e sem prática reflexiva em seu processo de aprendizagem pode ser atribuída à forma como aparece nos currículos de graduação, que por sua vez reflete currículos submetidos à lógica do Bacharelado ${ }^{40}$.

Apesar das Diretrizes Curriculares Nacionais de Formação de Professores e a consequente reformulação dos cursos de Licenciatura em Geografia no Brasil,

A cartografia, geralmente, encontra-se isolada nas matrizes curriculares, nos currículos escolares e nos livros didáticos, deixando, assim, de ser um instrumento para a compreensão da realidade social espacializada (LEÃO, 2008: 90).

No modelo de licenciatura que ainda se tem, apesar das orientações das DCNs, os conteúdos trabalhados ao longo do curso, e entre eles a Cartografia, são vistos como um conhecimento com fim em si mesmo, e não como deveriam ser, ou seja, os conhecimentos cartográficos deveriam ser meios para a construção do raciocínio geográfico.

Outro exemplo constatado de uma abordagem técnica da Cartografia nos cursos de Licenciatura encontra-se no estudo de Zuba (2013). A autora questionou os professores de Geografia, sujeitos de sua pesquisa, acerca da relação que eles estabeleceriam entre os conhecimentos didáticos específicos e os conhecimentos didático-pedagógicos. A autora constatou que, ao longo da formação acadêmica, houve dificuldade de os professores formadores (os

\footnotetext{
${ }^{40}$ Leão explica a lógica do bacharelado a que nos referimos no texto: o ciclo do bacharelado, que mantém as universidades federais sob o controle de sua lógica, inicia-se na graduação, que se transformou em algo parecido com um estágio ou laboratórios para a escolha dos "discípulos" que irão conduzir as pesquisas voltadas para o bacharelado nas pós-graduações. O graduando interessado em ingressar na pós-graduação alinha-se, ainda na graduação, a um campo do saber da Geografia, especializa-se em determinada área para compor os grupos de pesquisas e conquistar a confiança do seu pretendente a orientador no Mestrado. Na medida em que predominam professores com formação para o bacharelado, os escolhidos devem também possuir esse perfil. [...] Assim, a graduação constitui a fase inicial para a escolha daqueles que, na pós-graduação, irão garantir os projetos do bacharelado e a manutenção do controle do bacharel, também, nos mestrados e doutorados (Leão, 2008: 29-30).
} 
docentes universitários) relacionarem Didática ao conhecimento específico da Geografia. Finalmente, o que se constata é o obvio: "na licenciatura em Geografia, grande parte das disciplinas deveria utilizar a linguagem cartográfica" (ZUBA, 2013), o que não acontece.

Katuta (2010) apresenta algumas considerações relevantes para uma reflexão sobre a Cartografia na formação docente. Segundo a autora, dois importantes pressupostos influenciam a apropriação e o uso da linguagem da representação gráfica da Cartografia no Ensino Superior ou no Básico. O primeiro: "a apropriação e o uso da linguagem da representação gráfica da cartografia devem ser entendidos no contexto da construção de conhecimentos geográficos" (KATUTA, 2010: 133), portanto, não deve existir uma defesa da linguagem por ela mesma, o que poderia levar a uma perda da razão de ser de tal linguagem no ensino de Geografia no nível básico e superior, reitera Katuta (2010). A Cartografia por si só não se justifica, mas sua presença na Geografia deve ser justificada pela possibilidade de construção de conhecimentos geocartográficos, imprescindíveis para a interpretação e para a reflexão da realidade material e imaterial de um mundo em constante transformação.

O segundo: "a apropriação e utilização da linguagem da representação gráfica da Cartografia depende não só, mas em grande parte, das concepções de Geografia (e também de outras ciências como a matemática) e do ensino dessa disciplina que os professores e os alunos possuem" (KATUTA, 2010: 134).

Dessa forma, o lugar da Cartografia no ensino de Geografia estabelece-se em função das concepções dos que a utilizam,

Portanto, a linguagem cartográfica será apropriada e usada, tanto no ensino superior quanto no básico, dependendo das concepções que os diferentes sujeitos sociais possuem dos elementos a ela relacionados (educação, ensino, aprendizagem, escola, professor, Geografia, Ensino de Geografia e papel do aluno, entre outros). Sua trajetória, tanto no ensino superior quanto no básico, deve ser analisada como expressão de diferentes entendimentos de sujeitos sociais ligados ao exercício da profissão de Geógrafo e à docência em Geografia (KATUTA, 2010: 134). 
Ao compartilhar este trabalho, entendemos que, de nada adianta aumentar a carga horária para a Cartografia ou o número de disciplinas nos planos político-pedagógicos dos cursos de Geografia, se as concepções dos sujeitos - professores formadores de outros professores -, os conduzem a uma abordagem na qual a Cartografia tenha como objetivo apenas localizar e descrever lugares.

Além da ausência da concepção de Cartografia como uma linguagem que perpassa todas as temáticas da Geografia há, como referimos anteriormente, o problema da falta de identidade de muitos profissionais, que lecionam as disciplinas ligadas à Cartografia com a docência. Esse fator, certamente tem influência sobre como o professor apreende esse conhecimento ao longo do processo de formação e como o aplica ao longo de sua atuação na Educação Básica.

\subsection{Estado da arte da Cartografia na formação docente}

Podem ser reconhecidas três diferentes fases, pelas quais passou o uso e a apropriação da linguagem da representação gráfica da Cartografia no ensino de Geografia (KATUTA, 2010).

A primeira fase inicia-se por volta dos anos 1930 e vai até, pelo menos a metade da década de 1970, período em que a linguagem cartográfica era considerada instrumento básico da ciência geográfica, porém usada em grande parte para auxiliar a localizar fenômenos. A consequência dessa concepção foi uma subutilização da linguagem cartográfica, que não era utilizada para explicar a organização territorial da sociedade.

A segunda fase vai do final dos anos 1970 até o inicio da década de 1980. Marcada por um (des)uso do mapa (grifo da autora) nessa fase, observava-se na Geografia um período de mudança nos referenciais teórico-metodológicos, que dariam lugar à concepção conhecida como Geografia radical ou crítica.

A Geografia radical criticava a neutralidade científica enfatizada pela Geografia teórico-quantitativa e procurava mostrar que os produtos geográficos, ao invés de sua neutralidade, sempre foram utilizados pelo poder político e econômico. 
Propunham os defensores dessa corrente de pensamento a interpretação do espaço como produto social - resultante do modo de produção dominante na sociedade - e a negação do uso de técnicas consideradas quantitativas, por entenderem ter sido a Geografia reduzida ao serviço da ideologia dominante, o capitalismo. Entendiam, ainda, os teóricos da Geografia radical que a Cartografia estava entre tais técnicas.

Como consequência, observou-se que houve um descuido em relação aos conhecimentos técnicos e cartográficos, que poderiam auxiliar a profissionalização na área. Houve uma ênfase na "parte humana" da Geografia, em detrimento da parte técnica e física, o que deu margem a uma formação técnica e cartográfica deficiente do professor. A essas consequências, somavase o fato de que "vários profissionais que trabalhavam com os conhecimentos cartográficos em Geografia provinham de outras áreas do conhecimento (engenharia cartográfica, topografia, agrimensura)" (KATUTA, 2010: 136). Melo (2007) também concorda com essa análise, ao constatar que a falta de prioridade dos conhecimentos técnicos e cartográficos deixou uma lacuna no ensino superior. As reflexões que ocorriam estavam sob a perspectiva da Cartografia Sistemática.

A terceira fase de uso e de apropriação da linguagem cartográfica no ensino de Geografia compreende o período que vai do início da década de 1980 até os dias atuais, e foi marcado pela construção de outro olhar sobre a questão da Cartografia no nível superior e básico (KATUTA, 2010). Nesse período, aumentou o número de trabalhos científicos, de discussões e de debates em torno da apropriação e do uso da linguagem cartográfica no ensino básico ou superior. Há, nessa fase, uma (re)apropriação e uma construção de outros significados da importância da linguagem cartográfica (KATUTA, 2010).

Apesar dessa ressignificação da Cartografia, ainda se observa entre os especialistas da área, o consenso de que há deficiência dos professores em Cartografia:

Inúmeros trabalhos foram publicados sobre cartografia escolar, pesquisas realizadas e sistematizadas tanto na área da 
geografia quanto da educação. Entretanto, existe consenso a respeito da formação insuficiente dos professores e suas dificuldades para trabalhar com mapas. Na verdade, os conhecimentos específicos necessários às atividades com as representações gráficas em geral, não estão presentes nos currículos de formação de professores (ALMEIDA, 2009: 3).

O domínio de tais conhecimentos, entretanto, é considerado essencial no trabalho do professor de Geografia em sala de aula.

Simielli (2010: 89) conclui que

[...] o professor precisa estar bem informado quanto ao alfabeto cartográfico, pois só assim saberá transmiti-lo ao aluno. Isso diz respeito à formação dos professores e à sua capacidade para usar o mapa como meio de comunicação. Caso contrário, o mapa será usado apenas como recurso visual.

É preciso ressaltar que, nas concepções de Bertin, não existe alfabeto cartográfico. O que existe é a linguagem da representação gráfica da cartografia com sua sintaxe, sua pragmática e sua semântica, além de sua particular semiologia.

Esse consenso sobre a falta de conhecimento do professor de Geografia da Educação Básica a respeito dos conteúdos cartográficos tem impulsionado a elaboração de diversas pesquisas sobre a Cartografia na formação docente.

No conjunto das discussões iniciadas por Oliveira (1978) houve a estruturação de um campo de pesquisa denominado Cartografia Escolar. Nesse campo, uma das questões recorrentes e presentes em todos os colóquios realizados pelos grupos de pesquisa refere-se à formação do professor.

\subsection{Cartografia na formação do professor do Ensino Fundamental I}

Uma parte dos estudos em Cartografia na formação do professor debruça-se sobre um curso específico de formação de professores: a Pedagogia. A preocupação com os conhecimentos cartográficos dos professores das séries iniciais também é um tema abordado por autores como Richter (2012), Rios et al. 2012 e Miranda (2010). 
Richter (2012), ao investigar o conhecimento dos pedagogos sobre o processo de aprendizagem do mapa, identificou dificuldades na formação desses profissionais e falta de compreensão metodológica do por que ensinar, ou utilizar determinadas atividades. $O$ autor constata também uma significativa valorização da Cartografia escolar na formação do pedagogo. Esse avanço, no entanto, ainda não conseguiu eliminar ou diminuir as ações desarticuladas entre teoria e prática.

Há falhas na preparação do pedagogo para o ensino e a aprendizagem da Cartografia para o Fundamental I. Parte dessas deficiências poderia ser minorada, se no contexto da formação do pedagogo em Psicologia, fosse incluída a discussão da base psicológica que é necessária para o ensino do mapa, cujo processo inicia-se pela apreensão da noção de espaço, que envolve a psicogênese da noção de espaço, a qual passa por níveis específicos da evolução geral da criança na construção do conhecimento: do vivido ao percebido, e desse ao concebido ou ao representado.

Rios et al. (2012) analisaram as práticas de ensino e aprendizagem da linguagem da representação gráfica da Cartografia realizadas por professoras formadas em Pedagogia, que lecionam no $5^{\circ}$ ano do Ensino Fundamental. Os autores constataram deficiências no conhecimento teórico de Geografia e de Cartografia, e mostraram que essas dificuldades incidem negativamente nas práticas desenvolvidas pelas profissionais em sala de aula. Rios et al. (2012) questionaram a formação acadêmica de pedagogos, pois, se a formação inicial não garantiria a construção de conhecimentos da Ciência Geográfica e da sua principal linguagem gráfica, a Cartografia, "como pode o professor ensinar Cartografia escolar se não foi the permitido construir tal conhecimento durante a sua formação?". Esse trabalho é um, entre tantos, que destacam as consequências negativas de uma formação docente que não contempla as discussões de Geografia em seu processo formativo.

As práticas educativas e saberes docentes relacionados aos conhecimentos cartográficos para a abordagem do espaço local no currículo de Geografia dos anos iniciais do Ensino Fundamental (do $1^{\circ}$ ao $5^{\circ}$ ano) foram investigados por 
Miranda (2010). Nessa pesquisa, a autora constatou que os conhecimentos cartográficos estão presentes no currículo de Geografia de todo o Ensino Fundamental e Médio, mas não se verifica no currículo das séries iniciais, o que resulta em lacunas na formação dos estudantes. Tais lacunas são atribuídas à ausência de conhecimentos cartográficos na formação dos professores para o ensino nas séries iniciais da escola fundamental. A autora considera assim a formação acadêmica - também denominada inicial - um momento-chave, fundamental para a produção dos conhecimentos necessários para que o professor realize o trabalho educativo.

Analisando o trabalho de Miranda (2010), há de se ressaltar que o ensino da Cartografia não pode ser iniciado antes do $3^{\circ}$ ano, pois o desenvolvimento mental da criança ainda não dispõe de bases sólidas para a aquisição de novos conhecimentos relacionados à construção da noção de espaço e de sua representação. Tal fato requer todo um cuidado para que não sejam atropeladas as etapas do desenvolvimento mental dos alunos, pois não é a mesma coisa ensinar a ler, escrever e contar. Nesse sentido, o ensino e a aprendizagem da Cartografia, encontram muitas contribuições nos estudos de Piaget e Vigotsky.

Para discutir um vir a ser da Cartografia nos cursos superiores de Geografia na modalidade Licenciatura, entendemos ser necessário conhecer a realidade atual, ou seja, como a Cartografia é ensinada nos cursos de formação de professores.

Na educação infantil e no Ensino Fundamental I, que vai do $1^{\circ}$ até o $5^{\circ}$ ano, 0 ensino de Geografia é uma função desenvolvida por professor formado em Pedagogia. Apesar de não ter sido preparado para essa função, o pedagogo é o responsável pelo desenvolvimento das noções básicas em Geografia e, portanto, de conceitos básicos em Cartografia, que serão determinantes para o aprendizado geográfico nas séries posteriores.

Dados os limites da presente pesquisa, não nos aprofundaremos nas questões específicas da Cartografia nos cursos de Pedagogia, entretanto, não podemos desconsiderar que o pleno desenvolvimento da Geografia na Educação básica 
só se dará como resultado de ações conjuntas, que contemplem todas as etapas: da educação Infantil, passando pelo Ensino Fundamental I e o Ensino Fundamental II, até o Ensino Médio. Por isso, ainda que brevemente, tecemos algumas considerações a esse respeito.

Lesann é uma das autoras que apresenta contribuições nesse campo. A autora ressalta a preocupação com a formação dos professores de Geografia do Ensino Fundamental I, e afirma ser nessa fase do ensino que se dá a construção das bases para o Ensino Fundamental II, fase na qual atuará o licenciado em Geografia ${ }^{41}$. Lesann ressalta, inclusive, a importância da Geografia no Ensino Fundamental I, mas lembra que, nessa fase, "o aluno deve adquirir conhecimentos, para que adquira autonomia no estudo das áreas específicas do Ensino Fundamental II" (LESANN, 2009: 173).

O livro Geografia no Ensino Fundamental I (LESANN, 2009) é, portanto, uma resposta, às constantes queixas dos professores sobre "dificuldades de entender e dominar os conteúdos da Geografia" e um convite "ao professor e sua equipe pedagógica para uma reflexão a respeito dos objetivos, conteúdos e métodos pertinentes" a essa fase da escolarização (LESANN, 2009: 174).

Em uma análise exploratória, verificamos as grades curriculares de 27 cursos de Pedagogia de universidades federais brasileiras ${ }^{42}$. A análise das grades curriculares de cursos de Pedagogia permite inferir que a abordagem da Cartografia nos cursos de Pedagogia insere-se no âmbito das metodologias específicas do ensino, assim como História e Ciências. Em muitos casos, a disciplina Metodologia da Geografia compõe o núcleo de conhecimentos básicos dos cursos de Pedagogia. A julgar pela denominação das disciplinas, em alguns casos não há uma disciplina que aborda a Geografia, subentendendo-se que essa abordagem pode estar inserida em disciplinas tais como "Fundamentos e Metodologias das Ciências Humanas".

\footnotetext{
${ }^{41}$ Informação verbal proferida na participação da Mesa Redonda sobre Cartografia e Novas Linguagens no Ensino de Geografia, por ocasião do XI Encontro Nacional de Práticas de Ensino de Geografia ocorrido em Goiânia, em 2011.

${ }^{42}$ As universidades foram escolhidas de acordo com o Ranking universitário da Folha, 2012.
} 
Considerando essas questões e somando-se o fato de serem na maioria dos casos apenas uma disciplina para o ensino e metodologia da Geografia, percebemos que há muito pouco espaço para a discussão de uma Cartografia escolar renovada (FONSECA, 2004). Muito antes de se pensar em uma "Cartografia escolar renovada", é preciso que haja alguma Cartografia. É preciso contribuir para o enfrentamento da enorme lacuna constatada, quando se discutem ensino e aprendizagem da Cartografia no Ensino Fundamental I. Não é uma deficiência apenas em relação à Geografia.

Segundo Richter (2012: 4)

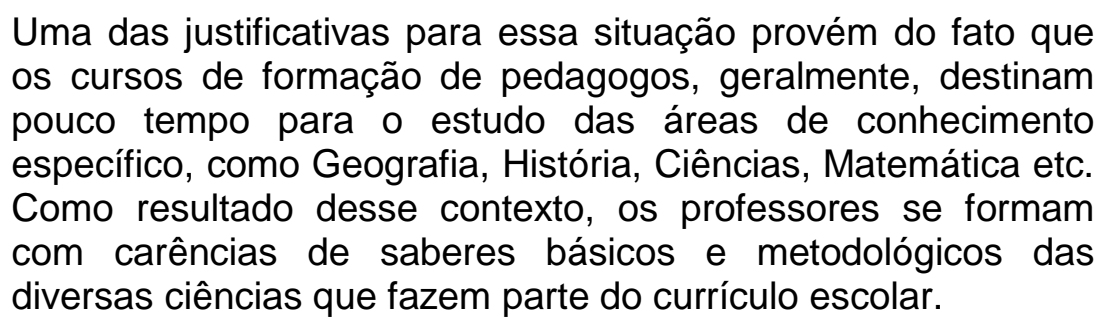

Se tantas disciplinas não são suficientemente contempladas, o que dizer da Cartografia? Ao analisar as bibliografias dos cursos de Pedagogia, percebe-se que elas não sinalizam a existência de alguma preocupação com a aprendizagem cartográfica. Dessa forma, os pedagogos atuantes no Ensino Fundamental I, do $1^{\circ}$ ao $5^{\circ}$ ano, em geral não têm preparo em Cartografia, mas como professores polivalentes têm de ensinar Geografia. No ensino de Geografia deveriam ser capazes de construir as bases que favoreceriam a aquisição de conhecimentos para as etapas posteriores, conforme apontam os especialistas.

Almeida, Cavalcanti e Bento (2011) discutem a prática docente dos professores das séries iniciais com conteúdos específicos da Geografia Escolar. Segundo esses autores, a estrutura curricular dos cursos de Pedagogia baseia-se em regulamentações antigas. Na matriz curricular, as disciplinas (Matemática, História, Geografia e Ciências) são imbricadas sob o rótulo de Ciências Sociais ou Ciências Humanas, não havendo tempo dedicado, ao longo do curso, a um aprofundamento específico em Geografia e uma reflexão sobre sua finalidade; o mesmo acontece com a Cartografia Escolar. 
Tal situação parece deveras preocupante, visto que nessa fase da escolarização, deveria haver uma atenção maior com os preparos elementares para o ensino do mapa para as crianças, no qual o primeiro passo seria oferecer-Ihes orientações corretas para a percepção e para a representação do espaço (OLIVEIRA, 1978). Essa preocupação é compartilhada por diversos especialistas na área da Cartografia Escolar.

Callai (2005) aponta a necessidade de uma reflexão sobre o ensino da Geografia nas séries iniciais, tida como potencialidade para uma leitura espacial do mundo.

Para a autora:

Por meio da geografia, nas aulas dos anos iniciais do ensino fundamental, podemos encontrar uma maneira interessante de conhecer o mundo, de nos reconhecermos como cidadãos e de sermos agentes atuantes na construção do espaço em que vivemos. E os nossos alunos precisam aprender a fazer as análises geográficas (CALLAI, 2005: 245).

Para que a Cartografia seja mais que um conteúdo no currículo, Castellar (2011) ressalta ser necessário que os professores compreendam os fundamentos teóricos da discussão cartográfica. Para isso, é preciso que tais conhecimentos sejam tratados na formação acadêmica, posto que, para ensiná-los, é preciso que tais conhecimentos sejam apropriados.

Desse modo, para Castellar (2011: 127):

[...] se desde a educação infantil a criança tiver acesso aos procedimentos e códigos da linguagem cartográfica, não temos dúvida de que ampliará sua capacidade cognitiva de leitor de mapas e dessa maneira, o mapa fará parte das análises cotidianas.

Quanto à afirmação de Castellar (2011), podemos compreender que muito além de aprender códigos, é necessário ter a certeza de que a criança está preparada para assimilar a noção de espaço para, depois, representá-lo. 


\subsection{Cartografia na formação do professor de Geografia}

Considerando o foco deste estudo, procurou-se realizar uma abordagem das diversas pesquisas sobre a Cartografia e a formação do professor de Geografia. É importante destacar que não temos a intenção de esgotar o tema através da apresentação de uma abordagem exaustiva de todas as pesquisas sobre Cartografia na formação do professor. Contudo, com o destaque para alguns trabalhos, objetivamos mostrar que o tema Cartografia na formação de professores tem sido alvo de preocupações da comunidade acadêmica envolvida na formação de professores de Geografia.

No livro Geografia e conhecimentos cartográficos: a cartografia no movimento de renovação da Geografia brasileira e a importância do uso de mapas, Souza e Katuta (2001) dedicam um capítulo para abordar o tema da formação docente, e destacam que houve, ao longo dos anos, a consolidação do "adestramento docente", segundo o qual o professor é um executor de tarefas elaboradas por outrem. Tal fato impede que o professor pense sobre 0 processo de ensino e aprendizagem. $O$ professor apenas executa, não se apropria de uma prática reflexiva (SCHÖN, 2000).

Souza e Katuta (2001: 66) atribuem essa atitude subserviente a uma precária formação desses professores e reconhecem a existência de uma crise não apenas de ordem econômica, organizacional ou de estrutura curricular na área da formação de professores, trata-se de "uma crise de finalidade formativa e de metodologia para desenvolver essa formação".

À semelhança de Tardif (2008), Souza e Katuta (2001) afirmam a existência de saberes fundamentais para que os alunos possam entender melhor o mundo:

[...] os conhecimentos cartográficos são indispensáveis para uma instrumentalização docente que tencione ensinar para os alunos a lógica da distribuição territorial dos fenômenos. A nosso ver, se o ensino de Geografia deveria ter a preocupação de instrumentalizar o aluno para que possa entender a lógica que norteia as diferentes territorialidades produzidas pela humanidade, os conhecimentos da cartografia geográfica são imprescindíveis para que se possa realizar o movimento do pensamento. (SOUZA; KATUTA, 2001: 77). 
Em pesquisa sobre o ensino da matéria Cartografia nos cursos superiores em Geografia em instituições nacionais, Sampaio (2006) analisou a estrutura das disciplinas de Cartografia como carga horária e grade curricular, e discutiu as dificuldades na formação do licenciado em Geografia.

Além das disciplinas Cartografia, Cartografia I e Cartografia Temática, o autor constata que há diversas disciplinas com conteúdo cartográfico, denominadas geoprocessamento e sensoriamento remoto.

$\mathrm{Na}$ formação do professor que ministra Cartografia na Licenciatura, Sampaio (2006) identificou formações variadas, desde bem específicas e correlatas como engenharia cartográfica - até aquelas sem relação direta com a Cartografia, como engenharia agronômica.

As ementas, segundo o autor, não seguem nenhuma padronização, mas contemplam basicamente elementos da Cartografia Sistemática. Sampaio (2006) afirma que vigora, nos cursos de Licenciatura, uma abordagem cartográfica descontextualizada da Geografia. Em um trabalho de cunho quantitativo, o autor aponta ao final de suas análises, sugestões de ementas e de objetivos para a abordagem cartográfica na Licenciatura em Geografia.

Outro trabalho que parece refletir um esforço de pesquisa no sentido de organizar os conhecimentos teóricos discutidos pelos principais autores em Cartografia escolar é o de Melo (2007), que resultou numa proposta que contempla o envolvimento dos acadêmicos em processos que partem da reflexão para a prática e contemplam a representação dos espaços de vivência até os espaços mais distantes.

A proposta de Melo está estruturada em três partes, mas interligadas, devendo, portanto, ser desenvolvidas em conjunto. A primeira parte refere-se à preparação teórica dos licenciandos e está relacionada principalmente à fundamentação teórica da Cartografia Escolar. A segunda parte da proposta de Melo diz respeito à preparação de práticas pedagógicas, que consistem em atividades baseadas na literatura referente à Cartografia Escolar e no saber cartográfico. A terceira parte consiste na aplicação das atividades. 
De nossa parte, percebemos que a intenção não foi de todo concretizada. $\mathrm{Na}$ segunda parte faltam as questões relativas à psicogênese da noção de espaço e à passagem da percepção para a representação de um espaço pela criança. $\mathrm{Na}$ terceira parte faltam as considerações iniciais sobre como preparar a criança para as atividades de representação da sala de aula. O texto final deixa transparecer que algo se perdeu no caminho.

Sem pretensão de discutir o mérito da proposta, parece que muito do que se vê nela já está posto, e é objeto de reflexão nos cursos de formação continuada de professores de Geografia; mas parece ainda faltar algo que possibilite ao professor apropriar-se da linguagem da representação gráfica.

A proposta de Melo (2007) guarda algumas semelhanças com a de Nogueira (2011), principalmente por refletirem uma necessidade de mudança e de avanço nas questões pertinentes à forma como a Cartografia Escolar se apresenta ou, não na formação do licenciando em Geografia.

Em artigo publicado na Revista Brasileira de Cartografia, Nogueira (2011) relata os caminhos que conduziram à criação da Disciplina Cartografia Escolar no curso de Licenciatura da Universidade Federal de Santa Catarina (UFSC). A autora explica que, em pesquisas junto a professores da rede pública estadual de ensino daquele estado, foram identificadas dificuldades desse público sobre o conhecimento teórico e prático da Cartografia.

Em outra pesquisa citada por Nogueira (2011), a autora constatou também que alunos das séries finais do Ensino Médio, apesar de saberem ler e contar o suficiente para serem admitidos na Universidade, não sabiam localizar-se usando mapas.

Considerando-se que parte dos problemas dos professores e dos alunos com os mapas poderia estar na formação de professor, foi proposta uma disciplina obrigatória na formação de licenciandos em Geografia denominada Cartografia Escolar para a Licenciatura em Geografia da UFSC. A disciplina aborda a teoria sobre o ensino, o ensino para portadores de necessidades especiais, os PCNs de Geografia, as geotecnologias, a internet e os mapas para ensinar 
Geografia, incluindo práticas a serem efetuadas em dois momentos distintos da disciplina, como mostra o programa inicial, organizado segundo as informações de Nogueira (2011: 14-15):

\section{Introdução}

1.1 O lugar da Cartografia na Geografia

1.2 A cartografia que se ensina na universidade e a cartografia do ensino fundamental e do ensino médio: o saber ensinado

1.3 Análise dos PCNs de Geografia: a Cartografia no ensino de Geografia

$1.4 \mathrm{O}$ desenvolvimento do conceito espacial pela criança

1.4.1 O espaço vivido, o percebido e o concebido

1.4.2 Relações Espaciais Topológicas Elementares

1.4.3 Relações Espaciais Euclidianas e Projetivas

1.5 A representação espacial: a importância do desenho das crianças

1.6 A representação espacial de crianças "especiais"

1.7 Reflexões sobre o triângulo pedagógico: aluno, disciplina e ensino, e o professor

2. Recursos cartográficos para o ensino de Geografia.

2.1 Os croquis de campo e mapas mentais

2.2 As maquetes geográficas

$2.3 \mathrm{O}$ atlas, o globo e os mapas de parede

2.4 Os mapas e maquetes táteis / baixa-visão

2.5 A bússola

2.6 O relógio solar

3. Cartografia no Ensino de Geografia nos níveis Fundamental e Médio

3.1 O uso dos produtos cartográficos nas diferentes faixas etárias

3.1.1 A alfabetização cartográfica: da $1^{\underline{a}}$ à $5^{\underline{a}}$ série

3.1.2 O uso de mapas para análise, localização, correlação e síntese: $6^{\underline{a}}$ série ao ensino médio

3.2 Prática:

3.2.1 Elaboração e aplicação de propostas de alfabetização cartográfica

4. Técnicas de Geração de Mapas.

4.1 Levantamentos diretos:

4.1.1 Topografia, GPS

4.2 Levantamentos indiretos

4.2.1 Aerofotos

4.2.2 Imagens de sensores orbitais

4.3 Relembrando a linguagem cartográfica - escala, projeções e coordenadas, representação

4.4 Os produtos cartográficos da internet

4.5 Prática: elaboração de um mapa de uso e cobertura da terra

4.6 Prática: elaboração e aplicação de propostas para o uso de mapas e imagens no ensino de Geografia.

5. Produtos cartográficos na escola

5.1 Armazenamento dos produtos cartográficos na escola

5.2 Escolha de produtos cartográficos para o ensino de Geografia

5.3 O computador e produtos disponíveis para o ensino da Cartografia

5.4 O lugar dos mapas produzidos pelas crianças

Analisando a proposta da disciplina, percebemos que sua estrutura reflete a formação de seus propositores: a formação em Engenharia Cartográfica.

Um aspecto positivo do programa é o de contemplar a cartografia tátil. Como ponto negativo, apontamos o fato de não contemplar a Cartografia Temática, 
muito usada na Geografia, e disciplinas correlatas. A autora considera que a nova disciplina no currículo tem sido uma experiência positiva. Em nossa perspectiva, compreendemos que, para não ser apenas mais uma disciplina de Cartografia no currículo dos licenciandos, seria necessário que sua abordagem estivesse voltada para a construção da linguagem cartográfica extremamente apropriada para o nível de ensino dos estudantes do Ensino Fundamental II e Ensino Médio.

Ainda refletindo sobre a experiência de Nogueira (2011), questionamos se apenas a inserção de uma disciplina implicaria em uma nova concepção de Cartografia como linguagem entre os docentes universitários que ensinam Geografia sob tantos recortes. As representações cartográficas passariam, com esse acréscimo, a ser utilizadas em todas as disciplinas do curso, seja das disciplinas físicas ou humanas? Parece-nos ser necessário, além de uma disciplina específica, uma mudança de concepção e de abordagem da Cartografia na formação acadêmica de professores de Geografia.

No nosso entendimento, valeria a pena a inserção de mais disciplina sobre Cartografia nos currículos dos licenciandos, se essa disciplina dispusesse de uma estrutura completamente diferente da apresentada, que ficasse mais próxima das crianças na idade em que ainda não podem aprender Cartografia, para passar pouco a pouco para o seu completo ensino e aprendizagem, acompanhando passo a passo o desenvolvimento das crianças.

Simião (2011), em seu estudo Cartografia e Geografia: uma breve discussão teórico-metodológica elabora reflexões sobre a aplicação prática do mapa como linguagem, no processo de ensino e aprendizagem em Geografia. Apesar de não tratar especificamente da formação de professores, a autora sempre aborda o tema ao longo de seu texto.

Ao assumir que, na prática docente, há uma subutilização do mapa, a autora destaca que o professor deve conhecer as propostas de renovação evidenciadas por Bertin e Gimeno, lá pelos idos de 1982, em que propunham a aplicação da Cartografia com base em exercícios de construção de mapas, não apenas simples leitura ou reprodução. 
Com base nessas ideias, convém questionar se os professores fazem seus próprios mapas ao longo do curso de formação acadêmica. Se fizerem, o fazem a partir do conhecimento dos limites e das possibilidades da gramática da representação gráfica?

Questiona Simião (2011: 85),

[...] a formação do professor não deveria contemplar a aquisição do conhecimento da linguagem cartográfica regida pela Semiologia gráfica, em prol do ensino de Geografia, uma vez que os alunos têm acesso aos mais diversos tipos de mapas, quer na mídia de um modo geral, quer nos materiais didáticos com os quais se depara na escola? O professor não deveria conhecer essa linguagem?

O professor deveria não apenas conhecer essa linguagem como também saber ensiná-la corretamente. Os questionamentos de Simião (2011: 85) sobre "Como seria a grade curricular de licenciatura em Geografia? Ela estaria estruturada para a aquisição de conhecimentos geocartográficos?" são os mesmos que direcionam nossas reflexões.

Em A cartografia na formação do professor de Geografia. Contribuições da Teoria no Ensino desenvolvimental, Moraes (2014) analisou projetos de curso e de disciplinas de Cartografia, consideradas pela autora similares, diferindo em relação à formação de professores críticos quanto à abordagem da Cartografia.

Nesse texto, Moraes (2014: 6) discute também a

[...] reformulação das disciplinas de Cartografia no Ensino Superior, em direção a uma melhor integração entre seus próprios conteúdos e, principalmente, entre Cartografia e as demandas da Geografia tanto na universidade quanto da escola básica.

Ao verificar o objetivo geral da pesquisa, podemos perceber sua complexidade:

[...] verificar se a organização de uma disciplina referenciada na Teoria do Ensino Desenvolvimental, proposta por Vasili Davidov, na qual a interatividade e os recursos multimídias possuem papel de destaque, auxilia na construção de conceitos e conteúdos de Cartografia, na compreensão dos princípios da Cartografia Escolar, na formação do pensamento teórico e no desenvolvimento de habilidades profissionais dos licenciados em Geografia (MORAES, 2014: 20). 
Segundo esse objetivo, Moraes (2014) elaborou uma proposta de reestruturação de disciplina de Cartografia Sistemática I, segundo os princípios da Teoria Desenvolvimental e experimentou tal proposta com 15 alunos integrantes do curso de Licenciatura em Geografia. A partir dessa experiência, a autora apontou a necessidade de tratar separadamente a Cartografia de sua versão escolar nos cursos de formação de professores.

Considerando tais estudos e as discussões aqui apresentadas, é possível constatar que a questão da Cartografia é uma instância problemática que deveria merecer atenção nos cursos de Licenciatura. Apesar dos problemas observados e das inúmeras propostas, a tese inicialmente proposta parece se confirmar.

Inicialmente, é possível afirmar que nos cursos de Licenciatura está faltando o básico, ou seja, o conhecimento da linguagem da representação gráfica - a Semiologia Gráfica - e sua utilização na elaboração de mapas, critica e análise de mapas. Além disso, em se tratando de formação de professor, falta uma compreensão da psicogênese da noção de espaço para depois chegar à sua representação. Entendemos que, a partir da representação, passamos a tratar de mapa, pois, dominando-lhe o conhecimento estariam sedimentadas as bases do uso do mapa para estudo e para aprender Geografia.

Além de aprender sobre coordenadas, projeções, escala, o professor precisa entender as implicações de tudo isso nos mapas, posto que só lê mapas quem aprendeu a construí-los. Parece que tudo passa pela concepção que se tem de Cartografia, vista como uma técnica, quando deveria ser encarada como uma linguagem. 


\section{A CARTOGRAFIA NO CURSO DE LICENCIATURA EM GEOGRAFIA: UM ESTUDO DE CASO}

\begin{abstract}
No fundo das teorias do currículo está, pois, uma questão de "identidade" ou de "subjetividade". Se quisermos recorrer à etimologia da palavra "currículo", que vem do latim curriculum, "pista de corrida", podemos dizer que no curso dessa "corrida" que é o currículo acabamos por nos tornar o que somos. Nas discussões cotidianas, quando pensamos em currículo pensamos apenas em conhecimento, esquecendo-nos de que o conhecimento que constitui o currículo está inextricavelmente, centralmente, vitalmente, envolvido naquilo que somos, naquilo que nos tornamos: na nossa identidade, na nossa subjetividade. Talvez possamos dizer que, além de uma questão de conhecimento, o currículo é também uma questão de identidade.
\end{abstract}

Tomaz Tadeu da Silva

Uma importância fundamental é atribuída ao currículo por Tomaz Tadeu da Silva (2013), em Documentos de Identidade: uma introdução às teorias do currículo,. Para o autor, a pergunta "o que ensinar?" nunca está separada de uma outra importante pergunta: "o que eles ou elas devem se tornar?".

De acordo com esse entendimento, ao representar um percurso a ser vivenciado, o currículo tem um compromisso estreitamente vinculado à identidade do profissional que se deseja formar.

Neste trabalho, a tese central aponta a necessidade de se repensar a maneira como os conhecimentos cartográficos são construídos ao longo do processo de formação acadêmica dos professores de Geografia. Para discutir tal postura, buscamos compreender a estruturação da Cartografia nos cursos de formação de professores, a partir de um olhar sobre a Licenciatura em Geografia. Partimos do pressuposto de que "o ensino de Geografia e de Cartografia são indissociáveis e complementares: a primeira é o conteúdo e a outra é a forma" (PASSINI, 2007: 148).

No percurso da discussão proposta, como professor-pesquisador encontramo-nos diante da necessidade de refletir sobre a realidade 
vivenciada na prática docente. Nessa trajetória, entendemos o processo de melhoramento profissional como uma conjugação de ensino e pesquisa.

O objetivo geral desta tese está vinculado a objetivos específicos dentre os quais: questionar a estruturação da Cartografia num curso específico de Licenciatura em Geografia e refletir sobre suas contribuições para a formação dos professores.

A proposição dessa discussão considera que é

[...] responsabilidade do professor criar contingências didáticas desafiadoras para seus alunos desvendarem os objetos de conhecimento, passando de simples identificação para análise e interpretação. Estamos propondo que a Cartografia Escolar seja uma linguagem que interaja com o sujeito, ajudando-o a desvendar o objeto de investigação: o espaço geográfico (PASSINI, 2007: 152).

As vivências como professor formador em cursos de licenciatura em Geografia e professor do Ensino Fundamental II e Ensino Médio permitiram-nos perceber a falta de condições para trabalhar com mapas em sala de aula. Além disso, muitos professores declaram a necessidade de maior fundamentação para 0 desenvolvimento dessa atividade. Passini (2007) afirma que o resultado disso é que, quando o trabalho com mapas em sala de aula acontece, a leitura de mapas se dá em nível elementar.

O avanço nos níveis de leitura de mapas e a formação do aluno como mapeador crítico e consciente é um processo que depende de diversas variáveis. Defendemos aqui a ideia de que uma dessas variáveis é a formação acadêmica, visto que "a prática educativa desempenhada pelo professor é, em grande parte, resultado do processo de formação inicial que obteve na academia" (ZUBA, 2013: 12).

É possível afirmar que uma formação acadêmica bem fundamentada contribui, e muito, para a autonomia do professor de maneira que ele possa refletir sobre o ensino que pratica, para analisá-lo e perceber possibilidades de mudança. Essa capacidade é uma demanda do dia-a-dia dos professores. Por essa razão, pretendemos discutir a existência de coerência entre a formação 
oferecida e a profissionalização esperada especificamente no tocante aos conhecimentos cartográficos, considerando que parte dos empecilhos que dificultam 0 processo de ensino e aprendizagem pode estar arraigada no próprio processo de formação (ZUBA, 2013).

Num contexto mais amplo, inferimos que as dificuldades de professores em desenvolver o conhecimento cartográfico com seus alunos, aliam-se a outros fatores como, por exemplo, o distanciamento entre instituições formadoras e sistemas de Ensino da Educação Básica. Além desse fator, percebemos que ocorre um tratamento inadequado do conteúdo, que se caracteriza pela dissociação entre teoria e prática, que não contempla, ao longo do processo de formação do professor de Geografia, o entendimento de como ocorre o processo de aquisição do conhecimento cartográfico e sua relação com a Cartografia Escolar.

É importante destacar que, em sua prática docente e na abordagem de uma infinidade de conteúdos com seus alunos, os professores mobilizam diversos saberes oriundos de suas experiências em diferentes instâncias de sua vida profissional e pessoal. Neste trabalho, tratamos especificamente dos saberes disciplinares que são construídos durante a formação docente nas instituições de ensino, por serem esses os saberes com os quais nos deparamos na prática e atuação como professor formador.

\subsection{Opções e caminhos metodológicos}

O campo de estudo da presente tese teve como foco o curso de Geografia da Universidade Estadual de Montes Claros (UNIMONTES). Tal curso tem como objetivo principal habilitar o graduando para o exercício do magistério em Geografia nas séries finais do Ensino Fundamental e Ensino Médio.

O curso de Geografia da UNIMONTES completou 50 anos de existência, em 2014, sendo Geografia um dos quatro primeiros cursos de ensino superior implantados no norte de Minas, em 1964, ainda pelas extintas Fundação Educacional Luiz de Paula (FELP) e Faculdade de Filosofia, Ciências e Letras (Fafil), primeiros embriões da atual Universidade Estadual de Montes Claros. 
Com aulas em salas cedidas pelo então Colégio Imaculada Conceição, a turma inicial contava com 16 alunos. Atualmente, o curso de Geografia na modalidade presencial é ministrado em dois campi. No campus-sede, o curso é ofertado em dois turnos (matutino e noturno) e tem 216 alunos regularmente matriculados. No município de Pirapora - distante aproximadamente $168 \mathrm{~km}$ de Montes Claros -, no curso noturno há 64 acadêmicos.

O curso de Geografia, no campus-sede, conta com uma estrutura de quatro salas de aula e oito laboratórios, nos quais grupos de estudos conciliam as atividades de ensino, pesquisa e extensão. O corpo docente do curso de Geografia é composto por 31 professores, dos quais 11 são doutores, 14 mestres e 6 especialistas.

É a partir da vivência profissional como professor formador neste curso que delimitamos nosso foco de análise. Em diversas oportunidades, observamos que os alunos do curso Geografia dessa instituição de ensino não apresentaram determinados conhecimentos relativos à Cartografia.

Em diferentes situações de aprendizagem, em sala de aula, nas quais foi necessária a mobilização de conhecimentos cartográficos, apesar de instigados e interessados na execução das atividades, os acadêmicos demonstravam-se inseguros. Em suas falas, atribuíam suas deficiências ao fato de que, do ponto de vista prático, pouco tinham feito até então. Em suma, demonstravam que Ihes faltava o preparo anterior na construção da noção de espaço e de sua representação. Tal fato aponta para a seguinte questão: se os alunos não apreendem os conteúdos da Cartografia Escolar na graduação, como vão ensiná-la na Educação Básica?

Sabemos, a partir de estudos anteriormente referenciados (SAMPAIO, 2006; NOGUEIRA, 2011; MELO, 2013; MORAES, 2014), que essa situação não se dá apenas no curso de Geografia da UNIMONTES, ou seja, dificuldades de apropriação e pleno desenvolvimento das habilidades cartográficas ocorrem também em outros cursos de formação de professores de Geografia em nível estadual e nacional. 
Com o objetivo de discutir a questão da Cartografia no curso de Licenciatura em Geografia da UNIMONTES, fizemos algumas escolhas e delimitamos caminhos metodológicos a serem trilhados.

Definimos, dada a natureza do objeto de estudo e na perspectiva da abordagem qualitativa, realizar o procedimento de análise documental nos Projetos Político-pedagógicos (PPP) de 2002, 2004 e 2008 do curso de Licenciatura em Geografia da UNIMONTES.

Nessa análise, num primeiro momento, realizamos uma abordagem geral sobre os diversos PPPs, procurando identificar os elementos que impeliram alterações identificadas no currículo do curso de Geografia. Num segundo momento, o objetivo principal foi observar as disciplinas relacionadas à Cartografia ao longo dos três planos e as prováveis alterações que teriam sofrido ao longo das reestruturações dos PPP.

\subsection{Organização curricular do curso de Licenciatura em Geografia da UNIMONTES}

A primeira legislação que exigiu um currículo mínimo de caráter nacional para os cursos de graduação foi a LDBEN № 4024/61. Em 1962, foi prescrito 0 primeiro currículo mínimo para o curso de Licenciatura em Geografia, destinado à formação de professor para atuar nas escolas de nível médio (ZUBA, 2013). Esse currículo passava a ter quatro anos de duração, com as seguintes disciplinas: Geografia Física; Geografia Biológica ou Biogeografia; Geografia Humana; Geografia Regional; Geografia do Brasil e Cartografia.

O curso de Geografia da UNIMONTES, com habilitação em licenciatura plena $^{43}$, começou a funcionar em 1964 e foi criado com o objetivo de habilitar professores para atuarem no ensino de $1^{\circ}$ e $2^{\circ}$ graus em escolas públicas e particulares de Montes Claros e região.

Mesmo com as dificuldades vivenciadas no país, em decorrência da intervenção militar, Zuba (2013) afirma que não houve impedimento para a

\footnotetext{
${ }^{43} \mathrm{Na}$ UNIMONTES, o curso de Geografia sempre foi de licenciatura; até a presente data não foi ofertado o curso na modalidade bacharelado.
} 
criação do curso, que se iniciou com 26 disciplinas no modelo $3+1^{44}: 3$ anos de formação inicial com conteúdos específicos e 1, em que se ministrava uma disciplina denominada Práticas de Ensino, com ênfase em questões voltadas para a educação.

No Quadro 8, apresentamos a estrutura curricular do curso de Licenciatura em Geografia de 1964 a 1971.

QUADRO 8: Estrutura curricular do curso de licenciatura em Geografia na UNIMONTES (1964-1971)

\begin{tabular}{|c|c|c|}
\hline Ano letivo & Série & Disciplina \\
\hline 1964 & $1^{\mathrm{a}}$ & Geografia Urbana \\
\hline 1964 & $1^{\underline{a}}$ & Fundamentos de geologia, pedologia e petrografia \\
\hline 1964 & $1^{\mathrm{a}}$ & Geomorfologia Normal \\
\hline 1964 & $1^{\mathrm{a}}$ & Meteorologia \\
\hline 1964 & $1^{\mathrm{a}}$ & Cartografia \\
\hline 1964 & $1^{\mathrm{a}}$ & Geografia da população \\
\hline 1965 & $2^{\underline{a}}$ & História econômica \\
\hline 1965 & $2^{\underline{a}}$ & Geografia do Brasil (Grande região Leste) \\
\hline 1965 & $2^{-a}$ & Geografia do Brasil (Grande Região Sul) \\
\hline 1965 & $2^{\mathrm{a}}$ & Climatologia \\
\hline 1965 & $2^{\underline{a}}$ & Antropologia \\
\hline 1965 & $2^{\underline{a}}$ & Geografia agrária \\
\hline 1965 & $2^{\underline{a}}$ & Geografia da Energia \\
\hline 1966 & $3^{\underline{a}}$ & Geomorfologia estrutural \\
\hline 1966 & $3^{\underline{a}}$ & Geografia Regional (continente americano) \\
\hline 1966 & $3^{\mathrm{a}}$ & Geografia da Industria \\
\hline 1966 & $3^{\mathrm{a}}$ & Grandes Regiões Meio Norte e Nordeste \\
\hline 1966 & $3^{\mathrm{a}}$ & Geomorfologia estrutural e oceanografia \\
\hline 1966 & $3^{\underline{a}}$ & Geografia Regional do continente africano \\
\hline 1966 & $3^{\underline{a}}$ & Geografia Regional do continente europeu \\
\hline 1967 & $4^{\underline{a}}$ & Geografia de Minas \\
\hline 1967 & $4^{\mathrm{a}}$ & Botânica \\
\hline 1967 & $4^{\text {a }}$ & Práticas de ensino \\
\hline 1967 & $4^{\underline{a}}$ & Geografia Regional continente asiático \\
\hline 1967 & $4^{\mathrm{a}}$ & Geografia física \\
\hline 1967 & $4^{\mathrm{a}}$ & Geografia Econômica \\
\hline
\end{tabular}

Fonte: Secretaria Geral da Universidade Estadual de Montes Claros da UNIMONTES, ZUBA: (2013).

44 O modelo "3 + 1" é aquele em que as disciplinas de natureza pedagógica, cuja duração prevista era de um ano, justapunham-se às disciplinas de conteúdo, com duração de três anos. É uma maneira de conceber a formação docente denominado modelo da racionalidade técnica. 
A estrutura curricular do curso de Geografia da UNIMONTES sofreu poucas alterações. Em 1972, ocorreu a inserção da disciplina Estudos dos Problemas Brasileiros que, em 1984, foi suprimida. A estrutura curricular conforme 0 "modelo 3+1" seguia a norma nacional e vigorou no curso de Geografia da UNIMONTES por mais de 15 anos com pequenas alterações (ZUBA, 2013).

Em 2001, com as transformações e as reformas educacionais, cuja palavra de ordem foi a educação voltada para o desenvolvimento de competências, foram aprovadas as Diretrizes Curriculares Nacionais do Ministério da Educação (DCNMEC) para a formação de professores da Educação Básica, em nível superior, para os cursos de Licenciatura, de graduação plena.

O Parecer CES - Câmara de Educação Superior - 492/2001, que regulamenta as diretrizes, preconiza que

A atual dinâmica das transformações pelas quais o mundo passa, com as novas tecnologias, com os novos recortes de espaço e tempo, com a predominância do instantâneo e do simultâneo, com as complexas interações entre as esferas do local e do global afetando profundamente o quotidiano das pessoas, exige que a Geografia procure caminhos teóricos e metodológicos capazes de interpretar e explicar esta realidade dinâmica (BRASIL, 2001: 10).

Esse parecer estabeleceu que os cursos de graduação em Geografia deveriam proporcionar $\mathrm{o}$ desenvolvimento das habilidades e das competências constantes do Quadro 9. 
QUADRO 9: Competências e habilidades estabelecidas pelas DCNMEC para os cursos de graduação em Geografia

\begin{tabular}{|c|c|}
\hline Competências e Habilidades Gerais & $\begin{array}{l}\text { Competências e Habilidades } \\
\text { Específicas }\end{array}$ \\
\hline $\begin{array}{l}\text { a. Identificar e explicar a dimensão geográfica } \\
\text { presente nas diversas manifestações do } \\
\text { conhecimentos; } \\
\text { b. Articular elementos empíricos e conceituais, } \\
\text { concernentes ao conhecimento científico dos } \\
\text { processos espaciais; }\end{array}$ & $\begin{array}{l}\text { a. Identificar, descrever, compreender, } \\
\text { analisar e representar os sistemas naturais: } \\
\text { b. identificar, descrever, analisar, } \\
\text { compreender e explicar as diferentes } \\
\text { práticas e concepções concernentes ao } \\
\text { processo de produção do espaço; }\end{array}$ \\
\hline $\begin{array}{l}\text { c. Reconhecer as diferentes escalas de } \\
\text { ocorrência e manifestação dos fatos, } \\
\text { fenômenos e eventos geográficos; } \\
\text { d. Planejar e realizar atividades de campo } \\
\text { referentes à investigação geográfica; } \\
\text { e. Dominar técnicas laboratoriais concernentes }\end{array}$ & $\begin{array}{l}\text { c. selecionar a linguagem científica mais } \\
\text { adequada para tratar a informação } \\
\text { geográfica, considerando suas } \\
\text { características e o problema proposto; } \\
\text { d. avaliar representações ou tratamentos; } \\
\text { gráficos e matemático-estatísticos }\end{array}$ \\
\hline $\begin{array}{l}\text { a produção e aplicação do conhecimento } \\
\text { geográficos; } \\
\text { f. Propor e elaborar projetos de pesquisa e } \\
\text { executivos no âmbito de área de atuação da } \\
\text { Geografia ; } \\
\text { g. Utilizar os recursos da informática; } \\
\text { h. Dominar a língua portuguesa e um idioma } \\
\text { estrangeiro no qual seja significativa a } \\
\text { produção e a difusão do conhecimento } \\
\text { geográfico; } \\
\text { i. Trabalhar de maneira integrada e } \\
\text { contributiva em equipes multidisciplinares. }\end{array}$ & $\begin{array}{l}\text { e. elaborar mapas temáticos e outras } \\
\text { representações gráficas. } \\
\text { f. dominar os conteúdos básicos que são } \\
\text { objeto de aprendizagem nos níveis } \\
\text { fundamental e médio; } \\
\text { g. organizar o conhecimento espacial } \\
\text { adequando-o ao processo de ensino- } \\
\text { aprendizagem em Geografia nos diferentes } \\
\text { níveis de ensino. }\end{array}$ \\
\hline
\end{tabular}

Fonte: Resolução CNE/CES 492/2001 (BRASIL, 2001: 11).

Nota: Os itens grifados correspondem às habilidades e às competências ligadas à Cartografia.

Por sua vez, a Resolução CNE/CES 14/2002 estabelece a existência de Projeto Político-pedagógico (PPP) como exigência para todos os cursos de graduação. Conforme a Resolução (BRASIL, 2002:1), o PPP deve atender às seguintes características:

Art. $2^{0} \mathrm{O}$ projeto pedagógico de formação acadêmica $\mathrm{e}$ profissional a ser oferecido pelo curso de Geografia deverá explicitar:

a) o perfil dos formandos nas modalidades bacharelado, licenciatura e profissionalizante;

b) as competências e habilidades - gerais e específicas a serem desenvolvidas;

c) a estrutura do curso;

d) os conteúdos básicos e complementares e respectivos núcleos;

e) os conteúdos definidos para a Educação Básica, no caso das licenciaturas; 
f) o formato dos estágios;

g) as características das atividades complementares;

h) as formas de avaliação.

Em 2002, em cumprimento das determinações legais, foi elaborado o primeiro PPP de Licenciatura em Geografia da UNIMONTES, cuja estrutura curricular organizava-se em três grandes áreas, consideradas "indispensáveis à construção do conhecimento" (ANEXO H). Nessa estrutura curricular, as disciplinas referentes aos conhecimentos cartográficos eram Cartografia, Cartografia Temática e Geoprocessamento.

Em 2004, o Projeto Político-pedagógico ganha uma nova versão e a estrutura curricular passa a ser organizada em três núcleos: básico, específico e pedagógico, sendo que as disciplinas Cartografia, Cartografia Temática e Geoprocessamento continuam sendo as disciplinas referentes aos conhecimentos cartográficos, situando-se na área denominada Instrumentalização em Geografia, no núcleo específico (ANEXO I).

Em comparação ao PPP 2002, o grande diferencial do PPP 2004 é a ampliação da carga horária. A elaboração do PPP 2004 ocorreu em função da necessidade de uma vinculação do curso com a prática. Para isso, houve em cada disciplina um incremento de carga horária destinada à prática de formação que "visa estabelecer a ligação entre a aprendizagem teórica de conteúdos e de procedimentos profissionais dos acadêmicos à sua efetiva atuação na educação básica" (MINAS GERAIS, 2004: 25).

O PPP 2004 estabelece que a carga horária destinada à prática de formação será desenvolvida do $1^{0}$ ao $8^{\circ}$ período pelo professor de cada disciplina priorizada na estrutura curricular, devendo ser planejada juntamente com 0 professor articulador da Prática de Formação e do Estágio Supervisionado.

Infelizmente, é comum nos cursos de licenciatura a atuação de professores formadores com dificuldade (ou desconhecimento pela falta de experiência) na aplicação de determinado conhecimento ou conteúdo na Educação Básica. Em virtude disso, e em função da obrigatoriedade de articulação entre a Prática de Formação e os conteúdos curriculares, o documento (MINAS GERAIS, 
2004: 30) apresenta sugestões de articulação para algumas disciplinas. Para as $12 \mathrm{~h} / \mathrm{a}$ da disciplina Cartografia, o documento sugere as seguintes atividades:

- Solicitar aos alunos que comparem o mapa-múndi de 1543 com um atual, apontando as semelhanças e diferenças.

Estimular os alunos a comparar os mapas do Brasil do século XVI e século XIX. Explique as principais modificações do espaço brasileiro ao longo desse tempo.

Leve para a sala de aula e peça aos alunos que tragam, também, vários Atlas geográficos, livros de Geografia, guias turísticos, jornais e revistas com roteiros turísticos. Proponha um trabalho de comparação entre os diferentes mapas, escalas e projeções.

- Providenciar folhas de papel quadriculadas e distribuir na classe. Forneça dados estatísticos de alguns temas, como desemprego, evasão escolar, preço de combustível, preço da passagem de ônibus, etc. e peça que elaborem gráficos: de barras, circular ou de linha. A interpretação das informações contidas nos gráficos é de suma importância para a Geografia.

Levar uma bússola para a sala de aula e deixar que os alunos a examinem. Mostre as partes que compõem 0 instrumento e como usá-lo para obter pontos de orientação.

Solicitar aos alunos que se organizem em pequenos grupos. Cada grupo será responsável por uma atividade na tarefa de elaboração da planta da escola. Oriente-os a estruturar o trabalho: que elementos devem ser representados, como montar a legenda, como fazer o cálculo da escala, etc. Arrume uma trena para os alunos medirem o espaço e estabelecerem a escala.

- Pedir a cada aluno que represente, sob a forma de uma planta simples, o trajeto que percorre de sua casa até a escola. Ajude a calcular a distância do percurso em quilômetros e a definir a escala e a legenda.

Solicitar a cada aluno que calcule, em quilômetros, a distância entre o lugar onde mora e o lugar em que costuma passar as férias.

Solicitar a leitura do livro "A volta ao mundo em oitenta dias", de Júlio Verne (Editora Ática). No momento do debate na sala de aula, poderão ser discutidas algumas questões, tais como: quanto tempo seria necessário para fazer semelhante viagem nos dias de hoje? Que instrumentos seriam usados? Que meio de transporte seria utilizado?

Para as 12 h/a de Prática de Formação na disciplina Cartografia Temática, esse documento (MINAS GERAIS, 2004:30) sugere os seguintes procedimentos:

Pedir aos alunos que observem os mapas político e divisão regional do Brasil: geográfica e geoeconômica; títulos, símbolos, regiões, estados, cidades. Estimulá-los a analisar a escala dos 
mapas. Chamar a atenção dos alunos para a legenda, as cores e seu significado no mundo real.

Solicitar a alguns alunos que façam, uma leitura oral do mapa usando a legenda.

- $\quad$ Estimulá-los a comparar as informações que cada mapa traz da sua cidade.

Leve para a sala de aula documentos cartográficos do bairro da escola. Com esse material (plantas, cartas topográficas, etc) peça aos alunos que, em grupos, interpretem os documentos e os comparem entre si, considerando a escala, a legenda e as fontes.

Analisando essas sugestões, é possível compreender sua razão de ser, considerando a desvinculação dos professores formadores com os conhecimentos cartográficos ou outros tantos conteúdos na Educação Básica. De nossa parte, consideramos que são insuficientes, ou estão muito distantes do que seria desejável para se promover um conhecimento da Cartografia como linguagem, de forma que os conteúdos geográficos fossem meios para a construção do raciocínio geográfico.

O PPP 2008 também foi uma demanda decorrente da prática de formação. Nesse PPP, a carga horária de prática de formação aumentou de 12 para 18 horas aula.

Esse documento (MINAS GERAIS, 2008: 24) estrutura-se em torno de três Núcleos/Dimensões formadoras do processo educativo, estreitamente relacionadas:

Formação Humanística/Artística/Científica (Currículo Inicial Humanista: formação do pensamento crítico, autônomo e amplo) - trata da criação e produção crítica do conhecimento humano, objetivando resgatar a produção criativa da ciência, da arte e da cultura como potencial articulador tecnológico e estético (e também econômico) na criação de redes de solidariedade intercultural. Forma enfim, para a integração social e cultural entre povos e nações, firmemente comprometida com o ideário de justiça, eqüidade e paz.

Organização do Processo Educativo - trata da construção dos domínios, competências e habilidades necessárias à formação de um profissional que compreenda as relações e mediações decorrentes da organização social, buscando desenvolver potencialidades para exercer sua profissão; relacionando possibilidade de intervenção social subsidiada pela reflexão, com vistas a mudanças substanciais na comunidade, na cidade e, conseqüentemente, no nosso país. 
Organização do Processo Social - relaciona-se à possibilidade de intervenção social, subsidiada pela reflexão que tem como partida a prática, buscando desenvolver suas potencialidades para exercer sua profissão também, com vistas a mudanças substanciais na comunidade local, na cidade, e, conseqüentemente, no nosso país.

Nessa concepção, a estrutura curricular passou a ter a outra organização (ANEXO J). As alterações que deram origem a esses três Projetos Políticopedagógicos, no curso de Licenciatura em Geografia da UNIMONTES, representaram uma resposta às demandas impostas pela legislação. Nesse caso, as Diretrizes Curriculares Nacionais do Ministério da Educação e Cultura (MEC), para a formação de professores de Geografia da educação básica em nível superior, impuseram a necessidade de mudança.

Contudo, tais diretrizes não foram capazes de promover as alterações curriculares e procedimentais que possibilitassem aos cursos de Licenciatura em Geografia a constituição de integralidade e terminalidade próprias (LEÃO, 2008). O aumento da carga horária e a obrigatoriedade, ou inserção de disciplinas relativas à Pratica de Formação, ainda não conferiram alteridade aos cursos de Licenciatura em Geografia.

\subsubsection{A Cartografia nos Projetos Político-pedagógicos 2002, 2004 e 2008.}

Considerando que, no ensino superior, a discussão do currículo materializa-se na discussão do PPP do curso, resolvemos por analisar as ementas relacionadas à Cartografia nos PPPs do curso de Geografia da UNIMONTES, com o propósito de identificar a presença da Cartografia e discutir se todo 0 potencial da disciplina estaria presente nesse programa.

Nessa fase, o procedimento de pesquisa foi a análise documental. Analisamos os três PPPs do curso de Geografia (MINAS GERAIS, 2002, 2004 e 2008). A atenção foi direcionada para as ementas e as bibliografias, por meio das quais procuramos verificar se a estruturação desses documentos permitiria a promoção da apropriação da linguagem da representação gráfica pelos futuros professores. 
Os três PPPs sempre disponibilizaram três disciplinas relacionadas à Cartografia. A primeira disciplina relativa à Cartografia, com a qual se depara o graduando no curso de Geografia é a disciplina denominada Cartografia.

No Quadro 10, são relacionadas a ementa e a bibliografia da disciplina Cartografia constantes dos PPPs 2002, 2004 e 2008 do curso de Licenciatura em Geografia da UNIMONTES.

QUADRO 10: A disciplina Cartografia nos PPPs 2002, 2004 e 2008 do curso de Licenciatura em Geografia da UNIMONTES

\begin{tabular}{|c|c|c|c|}
\hline & PPP2002 & PPP2004 & PPP2008 \\
\hline Ementa & $\begin{array}{l}\text { ACartografia: origeme conceitos. A evolução } \\
\text { histórica da cartografia. Orientação. Os } \\
\text { elementos da representação cartográfica. } \\
\text { Mapas e cartas. Gráficos. }\end{array}$ & $\begin{array}{l}\text { ACartoğrafia: origeme conceitos. A } \\
\text { evolução histónica da cartografia. } \\
\text { Orientaçãao. Os elementos da } \\
\text { representaçãa cartográfica. Mapas e } \\
\text { cartas. Gráficos. }\end{array}$ & $\begin{array}{l}\text { Cartografia: evolução histórica e conceitos. } \\
\text { Orientação cartográníca. Sistemas de referências. } \\
\text { Escala. Fuso horário. Projeợes cartográficas, } \\
\text { mapas e cartas. }\end{array}$ \\
\hline Bibliografia & 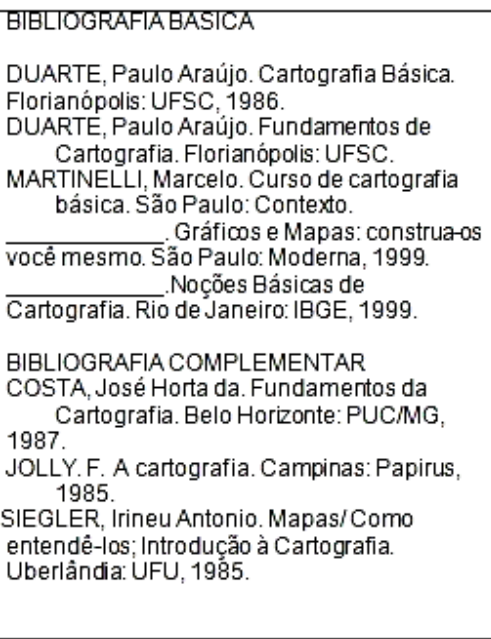 & 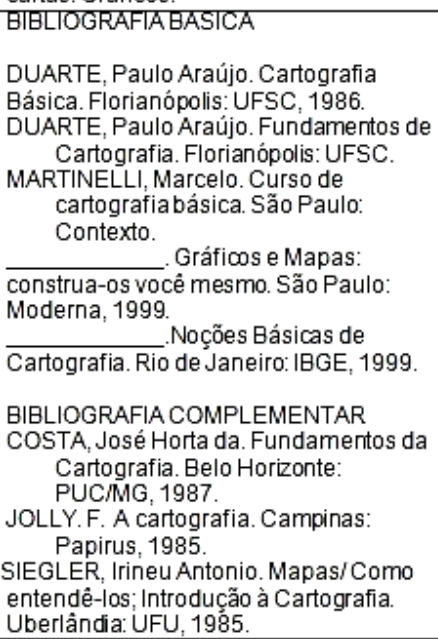 & $\begin{array}{l}\text { DUARTE, Paulo Araújo. Cartografía Básica. } \\
\text { Florianópolis: UFSC, } 1986 \text {. } \\
\text { MARTINELLI, Marcelo.Gráficos e Mapas: construa } \\
\text { os você mesmo. São Paulo: Modema, } 1999 . \\
\text { Noçốes Básicas de Cartografia. Rio } \\
\text { de Janeiro: IBGE, } 1999 \text {. }\end{array}$ \\
\hline
\end{tabular}

Fonte: Elaborado pelo autor a partir de MINAS GERAIS, 2002, 2004, 2008.

A disciplina denominada Cartografia, como disciplina instrumental, sempre existiu no curso de Geografia da UNIMONTES. Observando o Quadro 10, podemos notar que os tópicos da ementa pouco se modificaram, diferentemente da bibliografia.

Além de listagem com obras incorretas ou inexistentes, ao longo dos três PPPs, notamos que as referências bibliográficas, tornarem-se menos objetivas e completas, com o passar do tempo. Por outro lado, não observamos na ementa ou na bibliografia dessa disciplina qualquer referência que evidencie alguma vinculação com a formação de professores, objetivo primordial do curso de Licenciatura em Geografia em questão. 
A segunda disciplina relacionada à Cartografia nos PPPs analisados é a Cartografia Temática. No Quadro 11 podem ser identificadas a ementa e a bibliografia da disciplina Cartografia Temática, que compõem os PPPs 2002, 2004 e 2008.

QUADRO 11: A disciplina Cartografia Temática nos PPPs 2002, 2004 e 2008 do curso de Licenciatura em Geografia da UNIMONTES

\begin{tabular}{|c|c|c|c|}
\hline & PPP2002 & PPP2004 & PPP2008 \\
\hline Ementa & $\begin{array}{l}\text { ACartografia Temática e suas relaçōes com a } \\
\text { Geografia. A comunicação visio-espacial e a } \\
\text { semiologia gráfica. Elaboração, leitura, análise } \\
\text { e interpretação de cartas temáticas. } \\
\text { Fotointerpretação. GPS. GIS. }\end{array}$ & $\begin{array}{l}\text { A Cartografia Temática e suas relaçōes } \\
\text { com a Geografia. A comunicação visio- } \\
\text { espacial e a semiologia gráfica. } \\
\text { Elaboração, leitura, análise e } \\
\text { interpretação de cartas temáticas. } \\
\text { Fotointerpretação. GPS. GIS. }\end{array}$ & $\begin{array}{l}\text { A Cartografia Temática e suas relações com a } \\
\text { Geografia. A comunicação visio-espacial e a } \\
\text { semiologia gráfica. Elaboração, leitura, análise e } \\
\text { interpretação de cartas temáticas. } \\
\text { Novas técnologias aplicadas à cartografia. } \\
\text { Elaboraçãoe interpretação de perfis topográficos. }\end{array}$ \\
\hline Bibliografia & $\begin{array}{l}\text { BERTIN, J. La semiologie graphique. Paris: } \\
\text { EPI, 1975. } \\
\text { MARTINELLI, M. Curso de Cartografia } \\
\text { temática. São Paulo: Contexto, } 1991 \text {. } \\
\text { OLIVEIRA, C. Dicionário Cartográfico. Rio de } \\
\text { Janeiro: IBGE, } 1983 \\
\text { ROSA, Roberto. Introdução ao Sensoriamento } \\
\text { Remoto. Uberlândia : UFU, } 1994 \text {. } \\
\text { VERONESE, Valdir Francisco. A incorporação } \\
\text { do processo digital de imagens aos estudos de } \\
\text { recursos naturais: limitações e perspectivas. In } \\
\text { Revista Brasileira de Geografia. Rio de } \\
\text { Janeiro: IBGE. Vol. } 57 \text {. No } 3 \text { julho/setembro } \\
\text { 1995. }\end{array}$ & $\begin{array}{l}\text { ARCHELA, Rosely S., FRESCA, Tamia } \\
\text { M., SALVI, Rosana F. (org.) Novas } \\
\text { Tecnologias. Londrina: Ed. UEL, 2001. } \\
\text { BERTIN, J. La semiologie graphique. } \\
\text { Paris: EPI, 1975. } \\
\text { MARTINELLI, M. Curso de Cartografia } \\
\text { temática. São Paulo: Contexto, 1991. } \\
\text { OLIVEIRA, C. Dicionário Cartográfico. Rio } \\
\text { de Janeiro: IBGE, } 1983 \\
\text { ROSA, Roberto. Introdução ao a } \\
\text { Sensoriamento Remoto. Uberlândia : } \\
\text { UFU, 1994. } \\
\text { VERONESE, Valdir Francisco. A } \\
\text { incorporação do processo digital de } \\
\text { imagens aos estudos de recursos } \\
\text { naturais: limitações e perspectivas. In } \\
\text { Revista Brasileira de Geografia. Rio de } \\
\text { Janeiro: IBGE. Vol. 57. No } 3 \\
\text { julho/setembro } 1995 .\end{array}$ & $\begin{array}{l}\text { ARCHELA, Rosely S., FRESCA, Tamia M., SALVI, } \\
\text { Rosana F. (org.) Novas Tecnologias. Londrina: } \\
\text { UEL, 2001. } \\
\text { JOLY, Fernand. A Cartografia. Campinas: Papirus, } \\
\text { 1985. } \\
\text { MARTINELLI, M. Curso de Cartografia Temática. } \\
\text { São Paulo: Contexto,1991. }\end{array}$ \\
\hline
\end{tabular}

Fonte: Elaborado pelo autor a partir de MINAS GERAIS, 2002, 2004, 2008

Observamos no Quadro 11, que nos dois primeiros PPPs (MINAS GERAIS, 2002 e 2004) a disciplina Cartografia Temática, não trata, além dos tópicos tradicionais como elaboração, análise e interpretação de cartas temáticas, de tópicos como Fotointerpretação, do Global Position Sistem (GPS) e do Geographic Information System (GIS). Esses itens foram suprimidos no PPP 2008, devido à reformulação da disciplina Geoprocessamento, anteriormente opcional, que então passou a ser disciplina obrigatória no currículo dos graduandos.

Outra alteração observável é que a disciplina Cartografia Temática passa a denominar-se, no PPP 2008, Geocartografia. Não há, contudo, alteração nos tópicos da ementa ou da bibliografia que sinalize o porquê da alteração na denominação da disciplina. Além dessa alteração, como ocorreu com a disciplina Cartografia, a disciplina Cartografia Temática teve sua lista de 


\section{referências bibliográficas reduzida. A referência à Semiologia Gráfica está presente, ainda que sem especificações, nas ementas dos três PPPs.}

O Quadro 12 mostra a disciplina Geoprocessamento nos PPPs 2002, 2004 e 2008.

QUADRO 12: A disciplina Geoprocessamento nos PPPs 2002, 2004 e 2008 do curso de Licenciatura em Geografia da UNIMONTES

\begin{tabular}{|c|c|c|c|}
\hline & PPP 2002 & PPP2004 & PPP2008 \\
\hline Ementa & $\begin{array}{l}\text { Conceito de Geoprocessamento. Sistemas de } \\
\text { informações geográficas. Estrutura dos } \\
\text { sistemas de informações geográficas. } \\
\text { Georreferenciamento e geococificação. Banco } \\
\text { de dados cartográficos. Geoprocessamento } \\
\text { linear - segmentaçãa dinâmica. Sistema de } \\
\text { análise geográfica. Representação de dados } \\
\text { de mapas. Geoprocessamento aplicado à } \\
\text { análise e apresentação de informações } \\
\text { associadas a mapas digitais } \\
\text { georreferenciados. }\end{array}$ & $\begin{array}{l}\text { Conceito de Geoprocessamento. } \\
\text { Sistemas de informações geográficas. } \\
\text { Estrutura dos sistemas de informaç̃ões } \\
\text { geográficas. Georreferenciamento e } \\
\text { geococificação. Banco de dados } \\
\text { cartográficos. Geoprocessamento linear- } \\
\text { segmentação dinâmica. Sistema de } \\
\text { análise geográfica. Representação de } \\
\text { dados de mapas. Geoprocessamento } \\
\text { aplicado à análise e apresentação de } \\
\text { informações associadas a mapas digitais } \\
\text { georreferenciados. }\end{array}$ & $\begin{array}{l}\text { Conceito de Geoprocessamento. Sistemas de } \\
\text { informações geográficas. Estrutura dos sistemas de } \\
\text { informações geográficas. Georreferenciamento e } \\
\text { geococificação. Banco de dados cartográficos. } \\
\text { Geoprocessamento linear - segmentação } \\
\text { dinâmica. Sistema de análise geográfica. } \\
\text { Representação de dados de mapas. } \\
\text { Geoprocessamento aplicado à análise e } \\
\text { apresentação de informações associadas a mapas } \\
\text { digitais georreferenciados. }\end{array}$ \\
\hline \multirow[t]{2}{*}{ Bibliografia } & 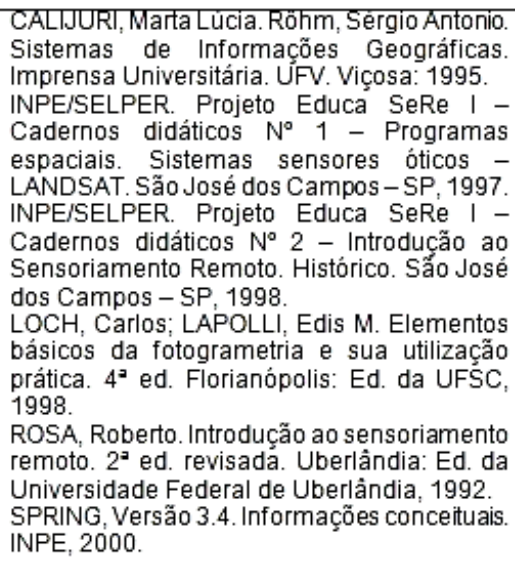 & 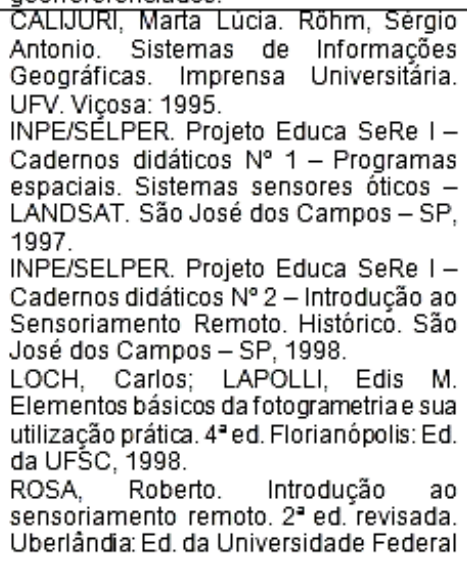 & $\begin{array}{l}\text { CALIJURI, Marta Lúcia. Rōhm, Sérgio Antonio. } \\
\text { Sistemas de Informações Geográficas. Imprensa } \\
\text { Universitária. UFV. Viçosa: } 1995 \text {. } \\
\text { LOCH, Carlos; LAPOLLI, Edis M. Elementos } \\
\text { básicos da fotogrametria e sua utilização prática. } 4^{2} \\
\text { ed. Florianópolis: Ed. da UFSC, 1998. } \\
\text { SPRING, Versão } 3.4 \text {. Informações conceituais. } \\
\text { INPE, 2000. }\end{array}$ \\
\hline & $\begin{array}{l}\text { BIBLIOGRAFIA COMPLEMENTAR } \\
\text { ASSAD, E. D., SANO, E. E. Sistemas de } \\
\text { Informações geográficas: Aplicações na } \\
\text { agricultura. Brasilia: EMBRAPA, } 1990 \text {. } \\
\text { EGNHOGER, M. J.; FRANK, A U. Perpective } \\
\text { news of GIS. Technologies and aplicated. In: } \\
\text { Simpósio Brasileiro de Geoprocessamento. } \\
\text { São Paulo: 1990. } \\
\text { RODRIGUES, M. Introdução ao } \\
\text { Geoprocessamento. In: Simpósio Brasileiro de } \\
\text { Geoprocessamento. São Paulo: 1990, pág. 1- } \\
\text { 26. }\end{array}$ & 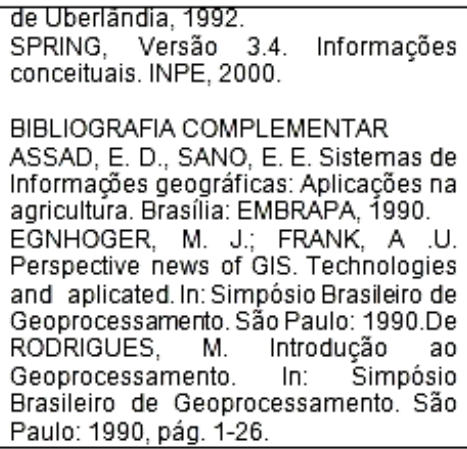 & \\
\hline
\end{tabular}

Fonte: Elaborado pelo autor a partir de MINAS GERAIS, 2002, 2004, 2008.

No PPP 2004, a disciplina era opcional, ou eletiva. No PPP 2008, a disciplina passa a compreender 72 horas aula. A ampliação da carga horária se deu em função da determinação de se desenvolver 18 horas de prática de formação. 
No projeto, não há indicação expressa ou sugestão de como deveria ser a prática de formação nessa disciplina.

A inserção da disciplina Geoprocessamento com essa ementa e bibliografia confirma a questão da lógica do bacharelado no curso de Licenciatura de Geografia da UNIMONTES. Muito celebrado foi o momento da oferta da disciplina no referido curso, mais ainda a estruturação do laboratório e do incremento de pesquisas nessa área. Tudo estaria normal, se não se tratasse de um curso cuja finalidade é formar professores.

A julgar pela ementa e pela bibliografia, não há evidências de discussão dos propósitos das tecnologias do Geoprocessamento ao ensino de Geografia. Há que se destacar que nos parecem ser muitas as possibilidades da utilização da tecnologia associadas ao Geoprocessamento no ensino. Um tímido exemplo disso são as possibilidades do Google Maps e programas como o Google Earth, que fornecem a visualização de partes do globo em versão cartográfica com a possibilidade de deslocamento, permitindo ao usuário encontrar as melhores rotas para seus percursos, com indicação de caminhos, sentidos das avenidas e pontos de referência, enquanto o segundo traz o planeta visto em mínimos detalhes (residências, árvores, carros, etc.). Essas ferramentas poderiam ser utilizadas com os graduandos como uma maneira dinâmica e interativa de trabalho com a Cartografia.

Há um domínio avassalador de geotecnologias no aprendizado das técnicas dos softwares de Geoprocessamento, alicerçado na crença de que possibilitaria a inserção do licenciado no mercado de trabalho, caso tenha se capacitado no domínio dos softwares. Em sua análise, Fonseca (2013) afirma que "os alunos são levados necessariamente a dominar o software de Geoprocessamento para que consigam, no momento atual trabalhar em estágio nas empresas" ${ }^{\prime 5}$.

\footnotetext{
${ }^{45}$ Informação verbal de Fernanda Padovesi Fonseca no, VIII Colóquio de Cartografia para Crianças e Escolas, na Mesa redonda denominada Currículo, formação de professores e práticas educativas, em 2013.
} 
Outra impertinência diz respeito às referências bibliográficas das disciplinas que, geralmente não são de "geógrafos cartógrafos que trabalham com uma cartografia geográfica", afirma Fonseca (2013). Normalmente, constam manuais dos softwares de geoprocessamento nas bibliografias dos cursos. Veja-se, por exemplo, a bibliografia dessa disciplina no curso de Licenciatura da UNIMONTES, que tem em sua brevíssima lista de três referências, um manual de software, o SPRING, Versão 3.4.

As Diretrizes Curriculares do MEC, para os cursos de Geografia tinham o objetivo de fazer com que a Licenciatura plena deixasse de ser apêndice e adquirisse identidade frente ao bacharelado, exigindo um projeto políticopedagógico específico, com percurso próprio, terminalidade e titulação definidas, de modo a romper com o tradicional modelo de formação de professores, que ficou amplamente conhecido como "como modelo 3+1". Apesar de o curso de Geografia da UNIMONTES nunca ter oferecido a modalidade bacharelado, todo o curso estruturou-se de forma subordinada à lógica do bacharelado, ou seja, as disciplinas oferecidas, seus tópicos e bibliografias pouco se diferenciavam de outros cursos de Bacharelado.

O mesmo ocorre com a Cartografia. Apesar de ser um curso de Licenciatura não se observa nos PPPs analisados, a formulação de uma disciplina que instrumentalize o professor para trabalhar e desenvolver a linguagem da representação gráfica com os alunos do Ensino Fundamental II e Médio.

A julgar pelas ementas e bibliografias, podemos afirmar que, apesar de ser um curso de Licenciatura, não há um tópico sequer, em nenhuma das três disciplinas do curso relacionadas à Cartografia (Cartografia, Geocartografia e Geoprocessamento) que reflita alguma relação com a formação do profissional a que o curso se destina: professores de Geografia do Ensino Fundamental II e Ensino Médio. 


\subsection{Conhecimentos cartográficos dos acadêmicos do curso de Geografia na UNIMONTES}

A discussão sobre a necessidade de estruturação da Cartografia no curso de Licenciatura pode indicar caminhos que sinalizam diversas opções. $\mathrm{Na}$ pesquisa efetuada para responder às questões propostas nesta tese, optamos por elaborar um levantamento dos conhecimentos cartográficos dos sujeitos da pesquisa: graduandos em Licenciatura em Geografia da UNIMONTES.

O levantamento foi feito por meio de um questionário (APÊNDICE A) com 7 perguntas, com o objetivo de verificar a apreensão de conceitos relacionados à Cartografia dos graduandos do curso de Geografia da Universidade Estadual de Montes Claros, matriculados no campus sede em Montes Claros.

O questionário foi aplicado a 63 graduandos, que já tivessem cursado as disciplinas Cartografia e Geocartografia, ministradas no $2^{\circ}$ e $3^{\circ}$ períodos. Portanto, responderam aos questionários alunos do $4^{\circ}, 6^{\circ}$ e $8^{\circ}$ períodos do curso de Geografia do campus Montes Claros ${ }^{46}$. A opção pelos graduandos desses períodos justifica-se por considerarmos que, depois de cursarem as disciplinas específicas da Cartografia, esses alunos teriam, teoricamente, ferramentas conceituais suficientes de compreensão da espacialidade dos fenômenos cartográficos já abordados.

Depois de levantados os dados, a pesquisa contemplou a fase de tratamento desse material, que envolveu i) ordenação, ii) classificação e iii) análise propriamente dita (MINAYO, 1994).

Dessa forma, cada questionário foi numerado na seguinte sequência Q1, Q2, Q3 até Q63. As respostas (APÊNCIDE B) de cada pergunta foram digitadas ${ }^{47} \mathrm{e}$ depois analisadas, de forma que pudéssemos identificar as noções que os respondentes tinham da Cartografia.

\footnotetext{
${ }^{46} \mathrm{O}$ curso de Geografia da UNIMONTES é ministrado em dois campi: Montes Claros e Pirapora.

${ }^{47}$ Todas as respostas foram transcritas ipsis litteris.
} 
O critério utilizado para o tratamento das respostas foi o agrupamento por afinidades, ou seja, procuramos identificar um padrão de respostas, ou até mesmo, de respostas que apontassem uma ideia comum que permitisse inferir a construção de uma noção ou conceito relativo à Cartografia. Para cada pergunta apresentada, selecionamos, dentre as respostas recebidas, aquelas que nos pareciam representativas daquele grupo ou padrão identificado.

\subsubsection{Análise das respostas dos graduandos aos questionários}

- Análise das respostas à questão 1 : Como você definiria a Cartografia?

Do total das 63 respostas recebidas para essa questão, identificamos 4 conjuntos. No primeiro conjunto de respostas, observamos que 37 definiam a Cartografia essencialmente como encarregada do estudo e da produção de mapas. Nesse conjunto foram agrupadas as respostas que, no nosso entendimento, ressaltavam as características matemáticas da Cartografia, como "Q.17" que definiu a Cartografia como a "Ciência matemática que busca criar e compreender as cartas".

Outros exemplos desse conjunto de respostas:

Q10. Ciência que reproduz o espaço através do mapa. Representação do meio, variando o tipo de abordagem, ou seja, vários tipos de temas.

Q42. Estudo dos mapas, cartas topográficas, analisando os mapas cartográficos.

Q63. É a ciência que trata dos estudos e operações tanto científica ou técnica relacionada à elaboração e utilização das cartas ou mapas de acordo com determinado sistema de projeção e uma determinada escala.

No segundo conjunto de respostas para a questão 1, identificamos 12 definições que, de alguma forma, associavam a Cartografia à Geografia, ou ainda, a uma de suas categorias como lugar, território, espaço. São representativas desse conjunto, as seguintes definições: 
Q53. Um ramo da ciência geográfica indispensável para o ser humano, pois esta estuda localização que é essencial para a vida humana.

Q60. É um ramo da Geografia que permite aprender sobre os mapas, fusos horários, escala de mapas e etc.

O terceiro conjunto de respostas à $1^{1}$ questão compreende aquelas que nos pareceram aproximar-se mais do esperado. Esse conjunto contempla 7 definições que, diferentemente das anteriores, não ressaltam as questões matemáticas ou subordinam a Cartografia à Geografia, mas que demonstram um entendimento da Cartografia como uma linguagem que contribui para a leitura das realidades espaciais, objeto de estudo da Geografia. Nesse grupo, algumas definições demonstram o entendimento da Cartografia como elemento que facilita, auxilia a compreensão de aspectos do espaço. Como exemplo desse conjunto, destacamos:

Q4. Uma ciência muito antiga e de suma importância para a Geografia e áreas afins, onde através da técnica representa no papel ou no mapa a imagem próxima do real, etc.

Q18. A cartografia é muito importante para os cidadãos, pois a partir dela que espacializamos o mundo. Mapas, gráficos, tabelas, croquis, maquetes, imagens de satélite.

Outras 7 respostas não se encaixaram em nenhum dos 3 grupos anteriores, por serem gramaticalmente mal elaboradas e, por isso, desprovidas de sentido. Nesse grupo, inclusive, insere-se a definição de um respondente que optou por apontar a deficiência no ensino e na aprendizagem da Cartografia como um dado dificultador da elaboração de uma definição:

Q53. Conteúdo que precisa ser abordado com melhor clareza no ensino médio e superior, assim poderia com clareza definir cartografia.

Há uma variedade de definições para a Cartografia como respostas. Algumas respostas demonstram uma atribuição de um forte componente matemático à Cartografia. Essa característica mostrou-se marcante para os respondentes.

A Cartografia moderna, ao se basear no conceito euclidiano do espaço e na matematização da sua linguagem, lançou as bases da Geografia acadêmica e promoveu sua emergência epistêmica como uma disciplina científica (Lévy (2012). Com o passar do tempo, Geografia e Cartografia se separaram. A 
Geografia experimentou uma trajetória epistemológica diferente, em que recebeu diversas influências que ampliaram a complexidade de sua análise sobre o espaço, que se tornou também cada vez mais complexo. A Cartografia, por sua vez, preservou seus princípios matemáticos, e em sua concepção como ciência exata fundamentada nas ideias de Descartes, parte do pressuposto de que a matemática seria a linguagem essencial e a única chave para desvendar a natureza. Nessa, concepção, o espaço pode ser expresso por meio de fórmulas algébricas, ou seja, o espaço considerado ideal é o espaço geométrico (SEEMANN, 2003).

- Análise das respostas à questão 2: 0 que você entende por alfabetização cartográfica?

Para essa questão, foi possível agrupar as respostas em 4 conjuntos. 0 primeiro conjunto compreende 33 respostas que associam a alfabetização cartográfica à compreensão dos elementos do mapa. Entendemos que essa associação estreita da alfabetização cartográfica ao entendimento do mapa é limitada, posto que implica um processo mais amplo de aquisição de noções espaciais que ultrapassariam a simples capacidade de ler um mapa. Dentre as respostas que se encaixam nesse grupo, selecionamos:

Q1.É o momento que o indivíduo aprende a entender o que o mapa representa.

Q4. Ensinar o aluno como ler e entender o mapa bem como suas propriedades.

Q5. Um meio de aprendizagem que envolve a utilização dos mapas em sala de aula.

Q6. Ensinar o aluno para a produção e interpretação de mapas.

No segundo conjunto de respostas sobre a alfabetização cartográfica, identificamos 15 respostas, que vinculavam a alfabetização cartográfica à detenção de noções iniciais para o entendimento do mapa, destacando a ideia de uma introdução ou a construção de conceitos iniciais sobre os mapas. Pode ser que as respostas desse grupo, demonstrem uma vinculação do termo alfabetização cartográfica à ideia principal do vocábulo "alfabetizar", ou seja, uma referência a apenas aprender o bê-a-bá do mapa. Neste conjunto, selecionamos: 
Q8.É o aluno ter uma noção básica de cartografia. Ex.: Saber ler um mapa.

Q.16 Refere-se a entender os conceitos básicos para conseguir interpretar e produzir gráficos, assim como os mapas.

Q20 Alfabetizar é ensinar algo a alguém seja qual for o ensino desde que a intenção seja a de buscar melhorias. Assim alfabetização cartográfica é repassar conhecimento básico de cartografia à pessoas que não conhecem ou não entendem o que esta representa.

Um terceiro conjunto de respostas para a alfabetização cartográfica compreende 3 definições que, no nosso entendimento, seriam as mais próximas do esperado, posto que vinculam o termo à ideia de processo, que seria algo mais complexo, implicaria em ir além das noções básicas, como também construir possibilidades de embasamento e aprofundamento para leitura, análise e interpretação das representações cartográficas e aplicação de tais capacidades na vida prática. Seriam representativas desse grupo de respostas, apenas 3 definições, a saber:

Q.13. É o ensinar de uma representação das diversas paisagens, o aluno tem que ter uma noção do espaço em que vive e saber representa-lo e localizá-lo.

Q.48 Conhecimento cartográfico não de forma superficial, mas sim com embasamento e considerável nível interpretativo das representações.

Q.54. Alfabetização cartográfica é o ensino da Cartografia, o ensino da leitura e interpretação dos mapas, criação de mapas.

Outras 12 respostas para essa questão foram consideradas vagas, sem uma construção lógica que permitisse perceber um padrão que se encaixasse nos conjuntos anteriores ou em um novo conjunto.

Em que pesem as divergências dos especialistas sobre seu significado e sua objetividade, a expressão alfabetização cartográfica é amplamente utilizada, Atualmente, trata-se de um conceito que se institucionalizou nos currículos oficiais, sendo, muitas vezes utilizada para designar um processo de aprendizagem da linguagem espacial, a linguagem cartográfica.

Desde o surgimento e a consolidação dos grupos de pesquisa em Cartografia Escolar, a expressão foi cada vez mais amplamente utilizada, dando margens a diversas críticas, que apontavam uma limitação ou restrição do termo, diante da complexidade envolvida na linguagem cartográfica. As críticas e os debates 
sobre o conceito refletem-se na falta de consenso entre os respondentes ao questionário.

De nossa parte, expressamos o nosso entendimento de alfabetização cartográfica como um processo que deve estar em articulação com uma educação participativa na formação da cidadania. Inserida no conjunto de formas pelas quais os homens se comunicam, a Cartografia no contexto de uma educação cartográfica consciente significa encaminhar os alunos ao exercício da aprendizagem com base na correta exploração das regras da sintaxe da linguagem cartográfica, seguido do aprendizado de sua leitura, análise e interpretação (MARTINELLI, 1999).

- Análise das respostas à questão 3: Qual a importância da Cartografia na formação do futuro professor de Geografia?

As respostas a essa questão revelam ser unânime o reconhecimento da Cartografia como um conhecimento importante na formação do professor. Ainda assim, é possível identificar 4 grupos de respostas. O primeiro grupo seria composto por 24 respostas que evidenciam a importância da Cartografia por possibilitar a localização. Nesse conjunto aparecem definições que demonstram um entendimento do mapa como um conteúdo a ser ensinado, por possibilitar uma localização dos fenômenos. Estariam entre as respostas desse grupo:

Q.5 De fundamental importância, pois através da cartografia nos localizamos espacialmente.

Q 6 É um importante recurso didático que deve auxiliar $o$ professor nas aulas de Geografia quase que em todos os conteúdos presentes na disciplina.

Q10 A cartografia é uma base para o professor tem de trabalhar o meio estudado. Na representação cartográfica pode-se colocar todas as informações de forma a "espacionalizar" ou regionalizar.

Q 11 É importante porque a Cartografia é eficaz para a leitura do espaço com um todo, localização, posicionamento, etc.

Entendemos que essa concepção que ressalta a importância da Cartografia pelas suas capacidades de permitir saber o "onde está?" é muito restritiva, se 
observamos suas reais potencialidades, como responder sobre as relações entre os fenômenos.

No segundo grupo de respostas, identificamos 9 delas que, pensamos expressar um entendimento um pouco mais abrangente da importância da Cartografia, quando os respondentes utilizam a palavra "representar".

Q30. Aprender a lidar com mapas, conhecer o espaço geográfico através das representações cartográficas, os mapas.

Q40. As representações cartográficas são de suma importância para o melhor entendimento do conteúdo, pela observação do espaço e de elementos representados.

O terceiro conjunto é composto por 6 respostas para essa pergunta, e destacam-se por demonstrar o entendimento da importância da Cartografia como metodologia, que serviria, inclusive para "facilitar o ensino". Dentre as definições, selecionamos:

Q2 A cartografia é de grande importância na formação dos futuros professores, através dela desenvolve-se habilidades de observação e espacialização que são fundamentais para a Geografia.

Q3 A importância da Cartografia para a formação do professor de Geografia é que ensina os mesmos a fazer seus próprios mapas para que trabalhem de forma mais interessante em sala de aula.

Q16 A cartografia é de grande importância na formação do professor pois a partir dela pode produzir mapas e interpretálos, usando ele como ferramenta de ensino para os alunos.

Q41 Para que o futuro professor tenha habilidades e métodos cartográficos para ensinar seus alunos com segurança.

O restante das respostas não se encaixa nas categorias anteriores e se destaca por ressaltar e reforçar a importância do mapa, mas sem explicar como ou o por que.

- Análise das respostas à questão 4: O que é um mapa? Para que serve um mapa?

No conjunto das 63 respostas, observamos que um grande número delas (37), destaca-se pela utilização do vocábulo "representação" na construção da 
definição, acrescido das palavras "gráfica", "visual”, "Geográfica”, "visual", "simbólica" e "cartográfica", como exemplificam as respostas selecionadas:

Q1. Mapa é uma representação de dados e serve para facilitar a compreensão do tema relacionado.

Q2. Um mapa é uma representação gráfica de determinado espaço físico. O mapa tem diversas finalidades (localizar, regionalizar, espacializar) entre outros.

$Q$ 15. É a representação de um determinado espaço. Para ajudar na localização dos dados ou informações mais precisas.

$Q$ 16. Mapa pode ser definido como uma representação visual de um determinado espaço geográfico. Ele serve para representar um espaço geográfico, podendo realizar uma classificação, estudas os espaços, regiões.

Outro conjunto de 7 respostas contempla aquelas nas quais os respondentes definiram o mapa como um desenho, o que poderia ser visto como sintoma de uma formação ineficiente, posto que é esperado que no curso de Geografia ciência em que o mapa tem um papel importante - houvesse o entendimento da diferença entre um mapa e um desenho. Algumas respostas selecionadas ilustram esse conjunto:

Q5. Um desenho que tem uma escala e um título. Serve para uma localização espacial e uma apresentação de dados.

Q3. O mapa é um desenho que termina com escala, título ou seja N, S, EW, ou seja localização específica.

$Q$ 12. É um desenho do meio físico, como relevo, hidrografia, vegetação, solo, etc.

Das 63 respostas, 4 compõem um grupo em que os respondentes utilizaram outros conceitos estudados nas disciplinas correlatas à Cartografia para construir uma definição de mapa, como carta, carta topográfica, projeção e escala. Entendemos como um sinal muito negativo a existência de tais definições, o que demonstra um grande equívoco na compreensão de conceitos extremamente básicos, o que não deveria ser verificado, considerando-se que os respondentes já concluíram pelo menos 2 disciplinas relacionadas à Cartografia. As respostas a seguir são ilustrativas desse conjunto:

Q6. O mapa é uma carta de localização. Ele tem várias utilidades, isso vai depender da finalidade do pesquisador. 
Q32. Carta topográfica que analisa questões políticas, econômicas e culturais etc. Representação do espaço em escala cartográfica. Serve para colocar em desenho todas as informações que consegue obter de um determinado assunto.

Q38. É uma projeção cartográfica da superfície terrestre. O mapa serve para nos orientar na superfície terrestre.

Q 40. Um mapa é escala que representa o tamanho de um espaço, orientação do lugar (espaço).

O último conjunto é composto por 15 respostas que demonstram uma grande dificuldade de definir claramente o que seria o mapa, como ilustram as respostas abaixo.

Q24 Uma espacialização do real em um plano. Trabalhar todo o mundo em sala de aula.

Q 41 É uma localização. Serve para identificar os lugares.

Q43 O mapa é uma parte diminuída até cem vez em um pequeno papel com a finalidade de localizar o que quer encontrar.

Convém destacar que, mesmo quando se tem uma associação do termo mapa à representação, é preciso atentar para o uso amplo dessa palavra, posto que é o termo corresponde a um vocábulo com multiplicidade de sentidos e de usos, o que demandaria um esclarecimento a partir de uma intensa reflexão teórica para o uso correto de um termo complexo para definir mapa. Apesar disso, o fato de 37 associarem o mapa à representação é extremamente positivo.

Quanto à pergunta Para que serve o mapa?, a função comum entre os respondentes é a de localização, sendo que apenas 2 respostas parecem reconhecer outra função que não seja essa, como ilustram as respostas a seguir:

Q45 Serve para se identificar e aprofundar e apontar resultados de pesquisas, deve conter título, legenda e fonte.

Q27 Serve para interpretação do espaço e fazer análise.

- Análise das respostas à questão 5: Nas disciplinas que você cursou ao longo da graduação, excetuando aquelas estreitamente vinculadas à Cartografia, como os conhecimentos cartográficos foram abordados? De que forma? 
Para essa pergunta, identificamos 3 conjuntos de respostas que, entre si, apresentam traços homogêneos. O primeiro conjunto compõe-se de 38 respostas que demonstram a compreensão de que, em outras disciplinas do curso de Licenciatura em Geografia, a Cartografia está presente no discurso desenvolvido pelos professores formadores ao longo da ministração de suas aulas. Alguns exemplos de respostas ilustram esse conjunto:

\footnotetext{
Q2 - Os conhecimentos cartográficos foram abordados através da apresentação e discursão (sic) de gráficos e mapas.

Q3 - Foram abordados de forma reduzida e foi através dos mapas.

Q4 - Foram abordados de forma simples. Foram associados sempre as disciplinas em questão por exemplo, migrações representada no mapa com o ponto de chegada e saída.

Q5 - Como forma de aula expositiva e prática. Leitura de mapas e de gráficos.

Q6 - Ao longo do curso tivemos a exposição de vários mapas (Clima, solo, vegetação, regiões, etc.)

Q7 - As outras disciplinas usaram dos estudos cartográficos para delimitarem suas áreas de ensino, como áreas de maior ou tipos de vegetação, lugares secos, industrias com maior abrangência entre outros.
}

Outro conjunto de respondentes optou por elaborar respostas marcadas pela expressão de uma crítica. Esse conjunto subdivide-se em outros dois: o das críticas positivas e o das críticas negativas. Entre as críticas positivas relativas à forma como a Cartografia é abordada nas demais disciplinas do curso de Geografia, temos 7 respostas, dentre as quais:

Q25 - Foram abordados de forma bem clara e objetiva.

Q46 - Foram abordados através de matérias que são utilizadas para representação cartográfica de maneira muito dinâmica.

Q56 - De forma geral, mas permitindo a compreensão da importância da cartografia para o ensino geográfico de modo geral.

Entre as 8 críticas negativas, selecionamos as seguintes:

Q18 - Sempre foram necessários, nem sempre foram trabalhados, assim como nem sempre foram compreendidos. Acredito que justamente pela falta de prática desde o ensino fundamental e médio e por este histórico, uma maior dificuldade do professor em lecionar essa disciplina.

Q20 - O ensino de cartografia na graduação é ineficaz e retrogrado. É sempre abordado de forma simplória e insuficiente.

Q47 - Foram abordadas de forma superficial, com um profissional que não possui formação nas ciências geográficas.

Q53 - Foram abordados de forma precária, deficiente com poucas práticas e pobreza no conteúdo. 
Outras 10 respostas compõem um grupo heterogêneo em que verificamos respostas, cuja construção gramatical foi insuficiente para o entendimento e a categorização. Como exemplo selecionamos:

Q21- Com referencia de espacialização. Usando em representações de lugares, situações, contextos históricos, que espacializam o estudo.

Q29 - Para saber calcular os rumos e os azimutes, através da regra de 3 para fazer os cálculos cartográficos, e os fusos horários de um local para outro.

Q54 - Na abordagem referente a regiões e localização.

- Análise das respostas à questão 6: Quais foram os principais conhecimentos construídos ao longo do curso sobre Cartografia Escolar?

Das 63 respostas recebidas, formamos 4 grupos. O primeiro grupo compreende 40 respostas em que os respondentes optaram por mencionar como conhecimentos sobre Cartografia Escolar, os tópicos de Cartografia de base como escala, coordenadas, orientação, gráficos, entre outros, como ilustram as respostas selecionadas a seguir:

Q21- Estudo de mapas, escala, cor, latitude, longitude, eixos, fusos horários.

Q22 - Análise de mapas bem como representação, interpretação e observação.

Q23 - Os conhecimentos construídos foram localização de espaço, coordenadas geográficas interpretação de mapas.

Q24 - Análise de mapas, interpretação, observação, detalhes.

Q25 - A cartografia escolar é uma base para todas as respostas, a Cartografia compreende todo o processo para aprender sobre fuso horário coordenadas geográficas saber onde nasce o sol, onde se põe, a rosa dos ventos, os pontos colaterais e subcolaterais, latitudes e longitudes.

O segundo grupo composto por 10 respostas expressam alguma associação com a Cartografia a ser desenvolvida na Educação Básica. Algumas das respostas desse grupo vinculam a Cartografia a uma metodologia que poderia facilitar o ensino de Geografia, como ilustram as respostas selecionadas:

Q1 - Que a cartografia pode ser um meio de atrair a atenção dos alunos e que a maioria das informações podem ser transformadas em mapas onde será possível a visualização das informações e facilitar a compreensão.

Q2 - Que é de grande importância trabalhar a linguagem dos mapas com os alunos.

Q6 - A utilização de mapas é um excelente recurso didático para a aprendizagem dos alunos do ensino médio e fundamental. 
O terceiro grupo compreende 10 respostas, cujos respondentes optaram por utilizar o espaço para elaborar uma crítica à forma como foi trabalhada a Cartografia Escolar ao longo do curso, como ilustram as selecionadas a seguir:

Q3 - O que eu observo é que existe uma grande dificuldade em se trabalhar a cartografia, e isso decorre da própria formação na área $o$ que para mim seria péssimo.

Q8 - Que essa se constitui em uma das grandes dificuldades no ensino de Geografia, essa dificuldade vem da formação de professores.

Q20 - Nos acadêmicos devemos conhecer a cartografia e dar aulas dinâmicas aos nossos alunos, sendo que as disciplinas cursadas na Universidade não deram base alguma.

Q21- Na verdade aprendi apenas a Cartografia e não teve ações voltadas para a escola. Aprendendo a fazer mapas (pouco) e não a ensinar.

O quarto grupo é composto por 2 questionários sem resposta para essa questão e 1 resposta muito vaga ou mal elaborada que não foi incorporada aos outros três conjuntos.

- Análise das respostas à questão 7: Com base na linguagem da representação gráfica de Bertin, explique se há e qual seria a diferença entre os dois mapas?

Os mapas mostrados (FIGURA 13 e FIGURA 14) representam o mesmo tema "Brasil - Rede Urbana Principal", sobre os quais solicitamos observações dos respondentes: 
BRASIL - REDE URBANA PRINCIPAL

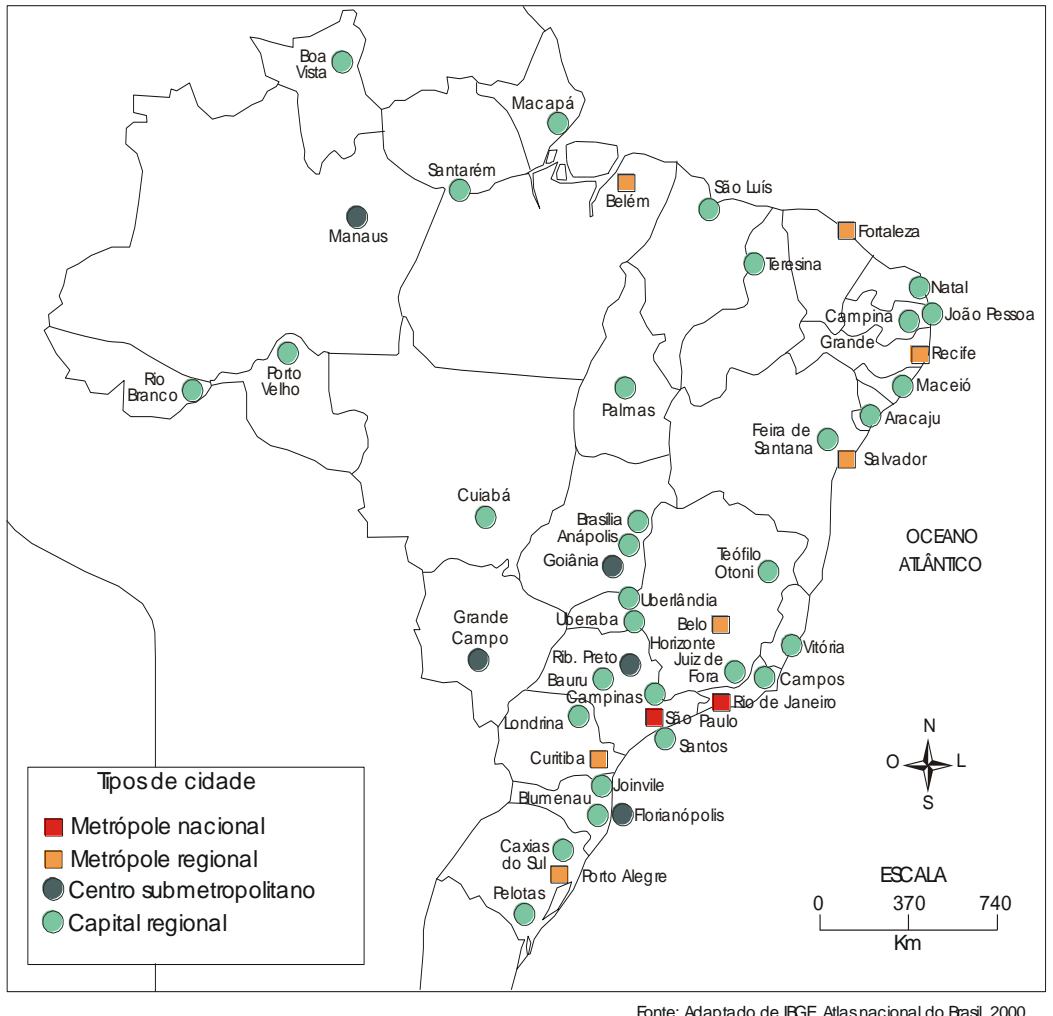

FIGURA 13: Mapa da questão 7a.

Fonte: Felbeque 2003, p. 63

BRASIL - REDE URBANA PRINCIPAL

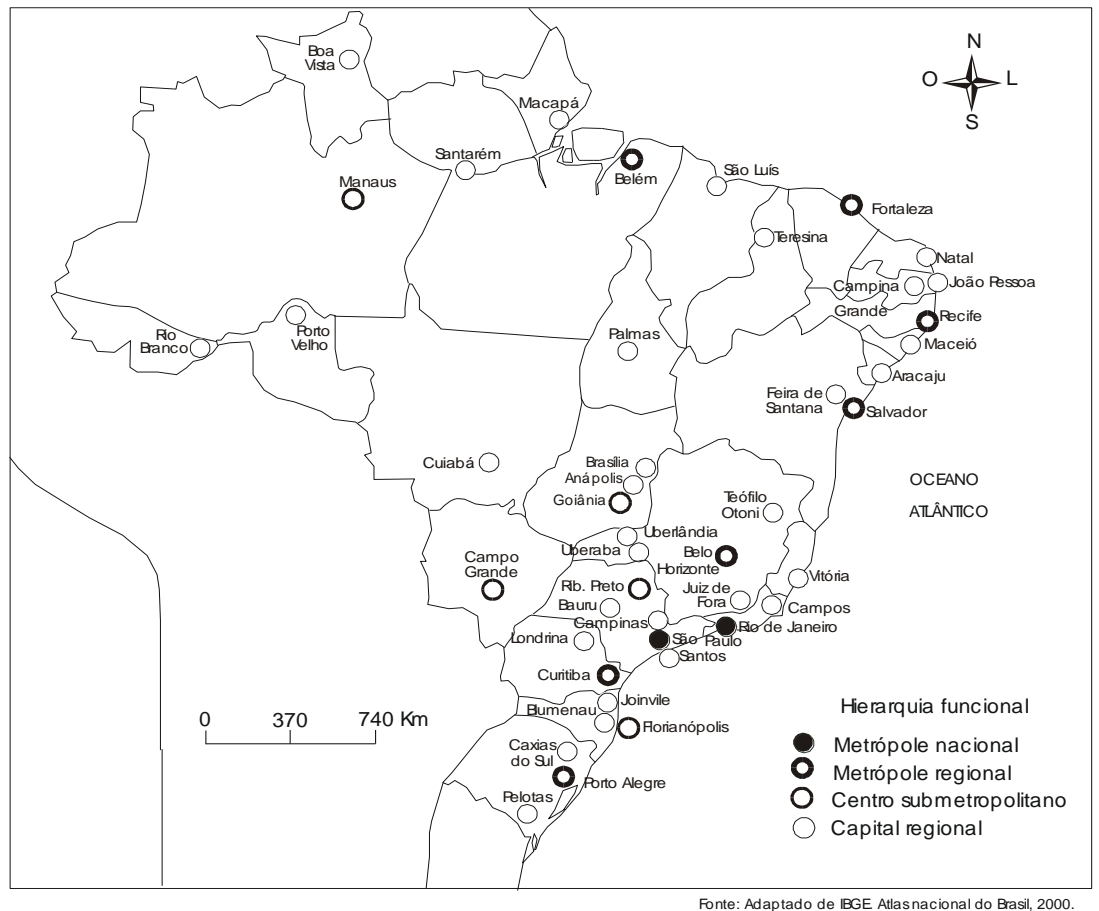

FIGURA 14: Mapa da questão 7a.

Fonte: Felbeque 2003, p. 63 
O componente é a rede urbana do Brasil e os elementos do componente são os tipos de cidade. O nível de organização do componente é ordenado, pois exprime a característica de hierarquia urbana. O comprimento do componente é quatro, isso é, apresenta quatro divisões (metrópole nacional, metrópole regional, centro submetropolitano e capital regional). No primeiro mapa, da maneira como está organizado, não é possível obter uma leitura global e imediata da informação. O leitor não consegue identificar a distribuição das cidades mais importantes em relação às cidades de menor importância, sem recorrer a uma memorização do significado dos signos contidos na legenda. No segundo mapa, a elaboração de uma legenda com o uso da variável tonalidade, variando na espessura dos círculos, traduz de forma imediata e correta a informação.

Para esses mapas, realizamos o seguinte questionamento: Com base na linguagem da representação gráfica de Bertin, explique se há e qual seria a diferença entre os dois mapas?

Do conjunto de 63 respondentes, 33 deles perceberam diferença na legenda, como ilustram as respostas a seguir:

Q39. Não sei quem é Bertin, mas percebo fontes e legendas diferentes.

Q40. Os símbolos da legenda.

Outro conjunto composto por 23 respostas apontaram diferenças as mais diversas entre os dois mapas, mas não citaram a legenda:

Q58. Há diferenças: um é um mapa por tipos de cidades e outro de hierarquia funcional.

Q32. É a diferença do crescimento do Brasil pela rede urbana. Principais tipos de cidade, metrópole nacional, regional, centro submetropolitano, capital, regional.

Q63. O primeiro mapa é oficial do IBGE e o segundo é a realidade do desenvolvimento urbano.

Um grupo de 7 alunos não respondeu à questão, dentre os quais incluem-se aqueles que informaram desconhecer a linguagem da Semiologia Gráfica de Bertin, como ilustram as respostas a seguir: 
Ainda em referência aos dois mapas, perguntamos: Qual dos dois mapas seria a melhor opção de representação para o tema e por quê?

Quanto à primeira parte da pergunta, 27 responderam que a melhor opção seria o primeiro mapa; 26 responderam que a melhor opção seria o segundo mapa; 5 responderam que os dois mapas são boas opções e 5 não souberam, ou não responderam.

Diante dessas respostas, podemos considerar que não se identifica uma orientação clara quanto à Semiologia Gráfica, pois se fosse assim, as respostas não seriam tão divididas.

Além de escolher esse ou aquele mapa como melhor opção, questionamos o porquê da escolha. Nesse momento, percebemos que, das 26 pessoas que apontaram como melhor opção o segundo mapa, as explicações são as mais variadas possíveis, como destacam as respostas selecionadas:

Q1- O segundo mapa tem a melhor representação pois as figuras são mais fáceis de diferenciação apesar de ter o mesmo formato.

Q10 - O segundo mapa pois um ano mais recente.

Q11 - O mapa 2 porque representa a hierarquia de cada região.

Q59 - O segundo pois a sua legenda está mais adequada ao mapa, facilitando sua interpretação.

BERTIN (1988: 49) salienta que "o problema é transcrever a ordem da informação e que esse problema só tem uma solução. A ordem dos dados transcreve-se pela ordem visual". No nosso caso, apenas 10 respondentes elaboraram respostas que expressam a percepção de ordem no nível de organização do componente, que procura evidenciar a hierarquia urbana, como mostram as respostas a seguir:

Q25 - O $2^{\circ}$ mapa, pois ele especifica a hierarquia das cidades, mostrando do maior nível maior para o menor.

Q48 - O segundo mapa, porque os símbolos do mapa, na legenda, estão em ordem crescente, de capital regional a metrópole nacional.

Q49 - O segundo mapa devido a representação ser de forma crescente.

Q56 - A legenda hierarquia do segundo mapa é mais fácil de ser compreendida, pois já norteia quem está lendo o mapa quanto a importância da cidade. 
Q10 - O segundo mapa tem a melhor representação pois as figuras são mais fáceis de diferenciação apesar de ter o mesmo formato.

Q25 - O 20 mapa, pois ele especifica a hierarquia das cidades, mostrando do maior nível maior para o menor.

Q48 - O segundo mapa, porque os símbolos do mapa, na legenda, estão em ordem crescente, de capital regional a metrópole nacional.

Q49 - O segundo mapa devido a representação ser de forma crescente.

Q56 - A legenda hierarquia do segundo mapa é mais fácil de ser compreendida, pois já norteia quem está lendo o mapa quanto a importância da cidade.

Considerando que a Semiologia Gráfica leva em conta a forma como percebemos as informações, esperávamos que, entre os graduandos do curso de Geografia, que já passaram pelas disciplinas de Cartografia, o nível de certeza e compreensão de qual seria a melhor opção de representação fosse bem mais alto.

Infelizmente, até autores, inclusive de livros didáticos, demonstram desconhecer os princípios básicos da representação gráfica e, como consequência disso, encontram-se vários documentos cartográficos que não traduzem de forma imediata e correta a informação presente nesse material.

\subsection{Refletindo sobre o estudo de caso}

Em toda a análise realizada neste estudo de caso, procuramos elencar elementos que permitissem discutir a tese relacionada à potencialidade da Cartografia na construção do raciocínio espacial e a consequente necessidade de repensar a maneira como os conhecimentos cartográficos são construídos ao longo do processo de formação acadêmica dos professores de Geografia.

Verificamos no estudo de caso empreendido que a Cartografia como disciplina no curso de Licenciatura é vista como um conteúdo isolado apenas no âmbito das disciplinas que abordam especificamente tal assunto. Apesar de existirem 3 disciplinas relacionadas à Cartografia, não há um tratamento específico para as questões do como ensinar essa temática na Educação Básica, campo de atuação dos futuros professores de Geografia.

Mesmo diante das diversas tentativas de aperfeiçoamento do Projeto Políticopedagógico do curso de Licenciatura em Geografia da Universidade Estadual de Montes Claros, a Cartografia ainda não recebeu, ao longo do curso, uma 
abordagem que possibilite aos futuros professores os conhecimentos necessários para um enfoque da Cartografia como metodologia para a aprendizagem dos conceitos geográficos como propõem diversos autores.

Dadas as potencialidades da Cartografia destacadas ao longo deste estudo, é possível afirmar que no curso analisado há limitação e prejuízo para os futuros professores. Por exemplo, não são abordadas com os licenciandos, questões relacionadas à necessária compreensão do processo de formação da noção de espaço nas crianças. Esse conhecimento é imprescindível para a educação cartográfica, desde as séries iniciais do Ensino Fundamental II, até o Ensino Médio, etapas nas quais atuarão os licenciados em Geografia.

Além da ausência dessas questões, cumpre salientar que não verificamos, ao longo das disciplinas constantes nos Projetos Político-pedagógicos e, tampouco nas respostas dos graduandos ao questionário, o necessário conhecimento da linguagem da representação gráfica.

É possível afirmar que temos no curso de Geografia da UNIMONTES uma Cartografia que se prestaria muito mais a uma formação em nível de bacharelado do que para a licenciatura e suas necessidades e demandas formativas específicas. Essa constatação também pode ser observada em outros cursos de formação de professores de Geografia em nível estadual e nacional como apontam as pesquisas já mencionadas ${ }^{48}$.

\footnotetext{
${ }^{48}$ GIRARDI(2001); SAMPAIO (2006); MORAES;(2014). Informações mencionadas no item "A Cartografia na formação do professor de Geografia".
} 


\section{CONSIDERAÇÕES FINAIS}

As discussões e as análises desenvolvidas ao longo deste trabalho refletem uma realidade que sempre constituiu nosso interesse e nossa preocupação no exercício da docência como formador de novos professores.

As afligentes questões discutidas nesta tese advêm da percepção diária da subutilização dos conhecimentos cartográficos no ensino de Geografia. Para exemplificar essa constatação, é fato que tanto no Ensino Fundamental e Médio, quanto no Ensino Superior, o mapa é tratado como um elemento ilustrativo, não como uma fonte de conhecimento, de informação e, ou de formação intelectual do estudante.

A presença do mapa como uma mera ilustração é comum em um bom número de livros didáticos utilizados por professores e alunos nas aulas de Geografia. Além disso, muitos professores que apresentam lacunas na sua formação acadêmica não conseguem superar essa visão limitada do uso do mapa.

Some-se a essa limitação o fato de que os professores do Ensino Fundamental e Médio e do Ensino Superior não vivenciam a construção de mapas, conforme as regras da linguagem da representação gráfica, a Semiologia Gráfica, ao longo do processo de formação e do exercício de sua profissão.

Desde Bertin e Gimeno, nos anos 82, a Cartografia vem se enriquecendo com a colaboração de novos estudos e pesquisas bem como com o uso e a aplicação de novas tecnologias na construção de mapas. Lamentavelmente, isso não significou alteração em como a Cartografia é abordada no processo de formação acadêmica de professores de Geografia.

O que entendemos, é que ensinamos uma Cartografia nos cursos de Geografia, na modalidade Licenciatura marcada por uma forma convencional, pois não incorporamos a Semiologia Gráfica de Bertin que, por força de novos estudos e de novas pesquisas tem se enriquecido e possibilitado um maior conhecimento do mapa, do mundo e do próprio homem. Isso talvez ocorra porque a Semiologia Gráfica, apesar de um conhecimento extraordinário sobre a comunicação visual, ficou confinada às paredes e às altas esferas das 
discussões acadêmicas, não sendo reconhecida ou incorporada nos cursos de graduação de bacharéis ou licenciados em Geografia.

A incipiente apropriação das contribuições de Bertin na formação de professores de Geografia no Brasil, em especial no ensino da Cartografia, tem produzido distorções tanto na abordagem do mapa (construção, leitura aprendizagem), quanto no ensino da Cartografia nos cursos de Licenciatura em Geografia e, por consequência, na própria prática da Educação Básica.

No processo de habilitação de professores para o Ensino fundamental II e Médio não podemos descartar ou, minimamente perder a noção da construção do espaço na criança e, como, depois dessa aquisição a criança passa para a representação do espaço. A esse respeito, entendemos ser necessária uma Cartografia inserida na formação, e amplamente presente na prática do estágio.

Às considerações concernentes à questão da formação de professores do Ensino Fundamental II e Médio, inserimos outra, não menos importante: a identidade do professor que forma em nível superior, o qual deve compreender que sua identidade deve depositar-se tanto no conhecimento da especialidade, como também no conhecimento da docência.

Além de não ter familiaridade com a educação básica, verifica-se, em certos cursos de Licenciatura, que o professor de Cartografia pertence à área de Engenharia, o que dificulta e, mesmo, impossibilita relacionar os conhecimentos cartográficos com os didático-pedagógicos. É necessário, pois, que na Licenciatura, estabeleçam-se o que é fundamental à "educação geográfica" e a responsabilização dos professores formadores de outros professores.

A tese que orientou este estudo defende que a potencialidade da Cartografia na construção do raciocínio espacial impõe repensar a maneira como os conhecimentos cartográficos são construídos ao longo do processo de formação acadêmica dos professores de Geografia.

As discussões aqui empreendidas permitem-nos afirmar que tal tese foi 
comprovada, ou seja, por todo o histórico realizado sobre a Cartografia, verificamos sua potencialidade como linguagem, que desde tempos mais remotos, permite aos seres humanos mais e mais compreensão do seu espaço de vivência e também de espaços longínquos. Vimos também que essa potencialidade manifesta-se e está presente nas orientações curriculares aqui analisadas (PCN e $\mathrm{CBC}$ ), ainda que em alguns momentos de forma equivocada como evidenciamos neste estudo.

Ao analisar o curso superior de Licenciatura em Geografia da UNIMONTES, entendemos que a realidade da abordagem da Cartografia nele verificada reflete muito provavelmente a realidade de outros cursos de Licenciatura em Geografia, posto que, é de conhecimento geral, estruturação muito semelhante.

Sendo assim, a potencialidade da Cartografia impõe repensar o processo de formação acadêmica de professores de Geografia. Essas discussões permitem-nos ainda afirmar a necessidade de um novo olhar para a Cartografia na Licenciatura em Geografia, especialmente no Curso ministrado na UNIMONTES. Essa constatação advém do fato de que somente lê mapas quem aprendeu a construí-los. Sendo assim, para ensinar, é imprescindível que o professor seja ele mesmo um "construtor de mapas"(mapping maker).

Entendemos que a Cartografia, no curso de Licenciatura em Geografia, deve contemplar as tradicionais disciplinas que abordam conhecimentos de Cartografia Sistemática e Geoprocessamento evidentemente reformuladas e direcionadas para o objetivo do curso: a formação de professores de Geografia.

Além disso, propomos a inclusão de uma disciplina que discuta especialmente a Cartografia a ser desenvolvida com os alunos do Ensino Fundamental e Médio: a Cartografia Escolar. Essa disciplina deveria priorizar inicialmente conhecimentos relativos à construção da noção de espaço nas crianças, de forma que ficassem claros os momentos e demandas para a abordagem de cada um dos conceitos cartográficos, respeitando a passagem da aquisição da noção de espaço para a posterior representação desse. 
Em tal disciplina deveriam ser contempladas discussões sobre os conteúdos prioritários a serem trabalhados com os alunos do Ensino Fundamental e Médio. Além disso, essa disciplina deveria abranger uma metodologia de abordagem dessa Cartografia, cujo objetivo deve ser a de fornecer aos alunos as condições necessárias para compreenderem o mapa como um meio de leitura, análise e síntese das realidades espaciais em Geografia. Seria um caminho para a formação de mapeadores conscientes e leitores críticos.

Além da abordagem de conteúdos e metodologias, a disciplina de Cartografia Escolar na Licenciatura deveria basear-se em um tratamento prático e aplicado da linguagem da representação gráfica, a Semiologia Gráfica, de maneira que permitisse aos professores o desenvolvimento da correta construção, leitura dos mapas pelos estudantes do Ensino Fundamental e Médio.

De outra sorte, convém considerar que de nada adianta aumentar a carga horária para a Cartografia ou o número de disciplinas nos planos políticopedagógicos dos cursos de Geografia, se as concepções dos sujeitos professores formadores de outros professores -, os conduzem a uma abordagem na qual a Cartografia tenha como objetivo apenas localizar e descrever lugares.

Há que se ter cuidado, posto que alteração do estado de coisas quanto à Cartografia na formação de professores requer, mais que a inserção de uma temática ou disciplina no currículo. Exige, sim, uma nova postura frente à Geografia e aos desafios que a ela se apresentam. Esse repensar deve passar necessariamente pela adoção de novas bases, por uma Cartografia que possa ser apreendida como metodologia para aquisição do conhecimento Geográfico.

Para caminharmos nessa direção, há muito que se fazer, nos cursos de Licenciatura em Geografia. $O$ trabalho aqui apresentado compreende um dos diversos esforços já empenhados e ainda necessários nesse sentido. Dessa forma, concretizamos a expectativa de contribuir, com as questões aqui abordadas, para a construção de um produto provisório capaz de dar origem a novas interrogações no que diz respeito à Cartografia na formação do professor de Geografia. 


\section{REFERÊNCIAS ${ }^{49}$}

ALMEIDA, R. R.; CAVALCANTI, L. S.; BENTO, I. P. A prática docente de professores dos anos iniciais, formados nos cursos de pedagogia, com conteúdos específicos da geografia escolar e o papel da formação inicial nessa prática. REUNIÃO ANUAL DA SOCIEDADE BRASILEIRA PARA O PROGRESSO DA CIÊNCIA, 63. 2011. UFG- Goiânia. Disponível em: <http://www.sbpcnet.org.br/livro/63ra/conpeex/pibic/trabalhos/REGIS_RO.PDF> . Acesso em: 15 out. 2013.

ALMEIDA, R. D. A propósito da questão teórico-metodológica sobre o ensino de geografia, Terra livre, São Paulo, n. 8, abr. 1991.

ALMEIDA, R. D. Uma proposta metodológica para a compreensão de mapas geográficos. 1994. 289 f. Tese (Doutorado em Educação) - Faculdade de Educação da UNESP, São Paulo, 1994.

ALMEIDA, R. D. Do Desenho ao Mapa: iniciação cartográfica na Escola. São Paulo: Contexto, 2001.

ALMEIDA, R. D. Cartografia Escolar. São Paulo: Contexto, 2007.

ALMEIDA, R. A. A Cartografia Escolar na Educação Diferenciada: Experiências com a Formação de Professores. Anais do COLÓQUIO DE CARTOGRAFIA PARA CRIANÇAS E ESCOLARES, 2009, Juiz de Fora. Anais... Juiz de Fora: Universidade Federal de Juiz de Fora, 2009.

ALMEIDA, R. D. Cartografia Escolar. São Paulo: Contexto, 2010.

ALMEIDA, Rosangela Doin de. Novos rumos da Cartografia escolar: Curriculo Linguagem e tecnologia. São Paulo: Contexto, 2011.

ALMEIDA, R. D.; JULIASZ, P. C .S. Espaço e tempo na educação infantil. São Paulo. Editora Contexto, 2014

ALMEIDA, R. D.; PASSINI, E. Y. O espaço geográfico: ensino e representação. São Paulo: Contexto, 1994.

ALTMANN, H. Influências do Banco Mundial no projeto educacional brasileiro. Educação e Pesquisa, São Paulo, v. 28, n. 001, p. 77-89. jan./jun. 2002. Disponível em: < http://www.scielo.br/pdf/ep/v28n1/11656.pdf>. Acesso em: 15 out. 2013.

ALVES, R. Sobre o tempo e a eternidade. Campinas: Papirus, 1996.

${ }^{49}$ De acordo com a Associação Brasileira de Normas Técnicas. NBR 6023, sistema autor-data. 
AMORIM FILHO, O. B. O contexto teórico do desenvolvimento dos estudos humanísticos e perceptivos em Geografia. In: Percepção Ambiental: Contexto teórico e aplicações ao tema urbano. Belo Horizonte: Instituto de Geociências, UFMG, 1987.

ANDRE, Y. Cohérence et fonctionnement d'un outil didactique. In: ANDRE, Yves. Enseigner les représentations spatiales. Paris: Anthropos, 1998.

ANDRE, Y.; BAILLY, A. Pour une geographie des représentations. In: ANDRÉ, Yves et al. Représenter l'espace: l'imaginaire spatial à l'école. Paris: Anthropos, 1989.

AUGUSTO, M. H. Regulação educativa e trabalho docente em Minas Gerais: a obrigação de resultados. Educação e Pesquisa., São Paulo, v. 38, n. 3, Sept. 2012 Disponível em: <http://www.scielo.br/scielo.php?script=sci_arttext\&pid=S1517-

97022012000300011\&lng=en\&nrm=iso >. Acesso em: 09 Jun. 2014.

BARATA, Filipe T. T. Cartografia: representação do espaço e unificação do mundo. Caderno de Geografia, Belo Horizonte, v. 7, n. 9, p. 18-28, jul. 1997.

BERTIN, J. Sémiologie Graphique. Paris: Mouton, 1967.

BERTIN, J. Sémiologie graphique: les diagrammes, les réseaux, les cartes. 2. ed. Paris: Mouton, Gauthier - Villars, 1973.

BERTIN, J. O teste de base da representação gráfica. Revista Brasileira de Geografia, Rio de Janeiro, ano 42, p. 160-181, jan/mar. 1980.

BERTIN, J.; GIMENO, R. A lição de cartografia na escola elementar. Boletim Goiano de Geografia, Goiânia, v. 2, n. 1, p. 35-56, jan./jun. 1982.

BERTIN, Jacques. Ver ou ler. In: REVISTA DA ASSOCIAÇÃO DOS GEÓGRAFOS BRASILEIROS. Seleção de textos: Cartografia Temática. São Paulo: AGB, n. 18, mai. 1988. p. 45-62.

BOGDAN, R.; BIKLEN, S. Investigação qualitativa em educação: uma introdução à teoria e aos métodos. Porto: Porto Editora, 1994.

BONIN, S. Initiation à la graphique. Paris: L'Epi, 1975.

BONIN, S. Novas perspectivas para o ensino da cartografia. Boletim Goiano de Geografia, Goiânia, v. 2, n. 1, p. 73-87, jan./jun. 1982.

BORGES, C.; OLIVEIRA, D. A. Olhares entrecruzados sobre as políticas e reformas recentes e seus efeitos sobre o trabalho e a prática docente, Revista Educação em Revista, Belo Horizonte, v. 44. p. 137-142, dez. 2006. 
BRAGA, R. B. Parâmetros Curriculares Nacionais de Geografia: elementos para uma discussão. In: ENCONTRO ESTADUAL DE GEOGRAFIA DE MINAS GERAIS, 3., 1997, Belo Horizonte. Anais... Belo Horizonte: AGB-UFMG, 1998, p. 24.

BRAGA, R. B. Tensões e interações entre o saber científico e o escolar: considerações sobre o ensino de geografia. In: DALBEN, A.; DINIZ, Júlio; LEAL, Leiva; SANTOS, Lucíola. Convergências e tensões no campo da formação e do trabalho docente. Belo Horizonte: Autêntica, 2010.

BRASIL. Lei de Diretrizes e Bases da Educação Nacional (LDBEN 9394/96), de 20 de dezembro de 1996.

BRASIL. Ministério da Educação e do Desporto, Secretaria de Educação Fundamental. Parâmetros Curriculares nacionais: História, Geografia (PCN's - 1aa 4aㅗ séries). Brasília: MEC/SEF, 1997.

BRASIL. Ministério da Educação e do Desporto, Secretária de Educação Fundamental. Parâmetros Curriculares Nacionais: Geografia (PCNs - $5^{\underline{a}}$ à $8^{a}$ séries). Brasília: MEC/SEF, 1998.

BRASIL, Ministério da Educação. Parâmetros curriculares Nacionais: ensino médio. Brasília: Ministério da Educação,1999.

BRASIL, Ministério da Educação. PCN + Ensino Médio: Orientações Educacionais Complementares aos Parâmetros curriculares Nacionais. Ciências Humanas e suas tecnologias. Brasília: MINISTÉRIO da Educação, 2000.

BRASIL, Ministério da Educação. Guia de Livros Didáticos de $5^{\mathbf{a}}$ a $8^{\mathrm{a}}$ séries. PNLD 2002. Brasília, 2001.

BRASIL. Resolução CNE/CES 492/2001, de 03 de abril de 2001. Disponível em < http://portal.mec.gov.br/cne/arquivos/pdf/CES0492.pdf > . Acesso em : 30 mai 2001.

BRASIL. Resolução CNE/CP 02/2002, de 19 de fevereiro de 2002.

BRASIL. Instituto Brasileiro de Geografia e Estatística. Censo Demográfico 2010. Disponível em : http://www.censo2010.ibge.gov.br. Acesso em: 27 novembro. 2013.

BRASIL. Ministério da Educação. Conselho Nacional de Educação. Despacho do Ministro sobre Parecer CNE/CP 009/2001: Diretrizes Curriculares Nacionais para a Formação de Professores da Educação Básica, em nível superior, curso de licenciatura, de graduação plena. Disponível em: <http://portal.mec.gov.br/cne/index>. Acesso em: 27 abril. 2013.

CALLAI, H. C. Aprendendo a ler o mundo: a Geografia nos anos iniciais do 
ensino fundamental. Cad. Cedes, Campinas, v. 25, n. 66, p. 227-247, mai./ago., 2005. Disponível em: <http://www.cedes.unicamp.br>. Acesso em: 10 fev. 2010.

CAPEL, H. Filosofía y ciencia en la Geografia contemporánea. Barcelona: Barcanova, 1981.

CASTELLAR, S.. Noção de Espaço e Representação Cartográfica: ensino de Geografia nas séries iniciais. 1996. Tese (Doutorado) - Departamento de Geografia da Universidade de São Paulo, São Paulo, 1996.

CASTELLAR, S.. VILHENA, J. Ensino de Geografia. São Paulo: Cengage Learning, 2010.

CASTELLAR, S. . A cartografia e a construção do conhecimento em contexto escolar. In: ALMEIDA, Rosangela Doin de. Novos rumos da Cartografia escolar: Curriculo Linguagem e tecnologia. São Paulo: Contexto, 2011.

CASTRO, J. F. M. História da Cartografia e cartografia sistemática. Belo Horizonte: Ed. PUC Minas, 2012.

CAVALCANTI, L. S. Concepções teórico-metodológicas da Geografia escolar no mundo contemporâneo e abordagens no Ensino. In: DALBEN, A.; DINIZ, Júlio; LEAL, Leiva; SANTOS, Lucíola. Convergências e tensões no campo da formação e do trabalho docente. Belo Horizonte: Autêntica, 2010.

CAVALCANTI, L. S. Geografia, escola e construção de conhecimentos. Campinas: Papirus, 1998.

CHIZZOTTI, A. Metodologia do Ensino Superior: o ensino como pesquisa. In.: Castanho, S. Castanho, M. E. (Orgs.). Temas e textos em Metodologia do Ensino Superior. Campinas: Papirus, 2001.

COLL, César. O construtivismo na sala de aula. São Paulo: Ática, 2004.

CRUZ NETO, Otávio. O Trabalho de campo como descoberta e criação. In: MINAYO, M. C. S.; DESLANDES, S. F.; CRUZ NETO, O.; GOMES, R. Pesquisa social: teoria, método e criatividade. Petropolis, RJ: Vozes, 1994.

DALBEN, A.; DINIZ, J. LEAL, L.; SANTOS, L. Convergências e tensões no campo da formação e do trabalho docente. Belo Horizonte: Autêntica, 2010.

DIAS, T. A. O espaço cartográfico enquanto escrita do poder. In: Simpósio Brasileiro de Cartografia Histórica, 1., 2011, Paraty. Anais... Paraty: UFMG, $2011 . \quad$ p. 1-11.Disponível em: $<$ https://www.ufmg.br/rededemuseus/crch/simposio/DIAS_THIAGO_ALVES.pdf >. Acesso em: 02 dez. 2013. 
DUARTE, P. A. Fundamentos de Cartografia. Série Didática. Florianópolis: Editora da UFSC, 2006.

FALLEIROS, Islê. Parâmetros curriculares para a educação básica e a construção de uma nova cidadania. In: NEVES, Lucia Maria Wanderley. A nova pedagogia: estratégias do capital para educar consensos. São Paulo, Xamã, 2005.

FARACO. C. A. Linguagem e diálogo: as ideias linguísticas do círculo de Bakhtin. Curitiba: Criar Edições, 1993.

FELBEQUE, R. A Cartografia no Ensino Fundamental no Brasil e no Quebec/Ca: o Atlas Escolar como um instrumento para o desenvolvimento do potencial didático da Cartografia. 2003. Dissertação (Mestrado em Geografia) Universidade Federal de Minas Gerais, Belo horizonte, 2003.

FERREIRA, W. A. O currículo de Geografia: uma análise do documento de reorientação curricular da SEE-RJ. 2009. Dissertação (Mestrado em Geografia) - Faculdade de Filosofia Letras e Ciências Humanas, São Paulo, 2009.

FONSECA, F. P. A inflexibilidade do espaço cartográfico, uma questão para a Geografia: análise das discussões sobre o papel da Cartografia. 2004. Tese (Doutorado em Geografia). Faculdade de Filosofia, Ciências Humanas e Letras da Universidade de São Paulo, 2004.

FONSECA, F. P. A Naturalização como obstáculo à inovação da Cartografia Escolar. Revista Geografares, n. 12, p.175-210, Julho, 2012.

Disponível em: < http://periodicos.ufes.br/geografares/article/view/3192/2402> Acesso em: 21 abr. 2013.

FONSECA, F. P.; OLIVA, J. Cartografia. São Paulo: Melhoramentos, 2013.

FONSECA, Marília. O Banco Mundial e a Educação: reflexões sobre o caso brasileiro. In: GENTILI, Pablo (Org.). Pedagogia da Exclusão: 0 neoliberalismo e a crise da escola pública. Petropólis: Vozes, 1995.

FRIGOTTO, G. Os delírios da Razão: da crise do capital e metamorfose conceitual no campo educacional. 77- a 108. In: GENTILI, Pablo (Org.). Pedagogia da Exclusão: o neoliberalismo e a crise da escola pública. Petrópolis: Vozes, 1995.

FURTADO, Júnia Ferreira. Oráculos da geografia iluminista: Dom Luís da Cunha e Jean-Baptiste Bourguignon D'Anville na construção da cartografia do Brasil. Belo Horizonte. Belo Horizonte: Editora UFMG, 2012.

GAMBOA, S. S. Pesquisa em educação: métodos e epistemologias. Chapecó: Argos, 2007. 
GATTI, B. A. et al. Formação de professores para o ensino Fundamental: instituições formadoras e seus currículos. Fundação Carlos Chagas, 2010. Disponível em: <http://www.fvc.org.br/estudos-e-pesquisas/avulsas/estudos1-3formacao-professores.shtml?page=7>. Acesso em 17 mai. 2013.

GENTILI, P. (Org.). Pedagogia da exclusão: crítica ao neoliberalismo em Educação. Petrópolis: Vozes, 1995.

GIMENO, Roberto. Apprendre à l'école par la graphique. Paris: Retz, 1980.

GIMENO, Roberto. Uma abordagem da cartografia na Escola Elementar. Boletim Goiano de Geografia, Goiânia, v. 11, n. 1, p. 104-125, jan./dez. 1991.

GIRARDI, Gisele. A cartografia no Ensino Superior de Geografia: Desafios e possibilidades. ANAIS COLÓQUIO DE CARTOGRAFIA PARA ESCOLARES. 4. FÓRUM LATINOAMERICANO, 1. Ano 19 (2): 7-42 (2001). Disponível em < http://periodicos.uem.br/ojs/index.php/BolGeogr/article/view/14274/7580>.

Acesso em 21 fev. 2014.

GIRARDI, Gisele. Mapas alternativos e Educação Geográfica. Revista Percursos, Florianopolis, v. 13, n. 2, p.39-51, jul-dez. 2012. Disponível em: < http://www.periodicos.udesc.br/index.php/percursos/article/view/2759/2196 $>$. Acesso em: 19 jan. 2014.

GRECO, F. A. S. Com que referências trabalham os professores no currículo no Ensino Médio? Um estudo sobre o ensino da Geografia nas Escolas - Referência de Uberlândia - MG. 2012. Tese (Doutorado em Educação) - Faculdade de Educação. Universidade de São Paulo, São Paulo, 2012.

HARLEY, B. Mapas, saber e poder. Revista Confins [Online], 5, 2009. Disponível em: < http://confins.revues.org/5724>. Acesso em: 11 jun. 2013.

HARLEY, J. B. A nova história da Cartografia. O correio da Unesco - Mapas e cartógrafos. São Paulo: FGV, 1991.

HARLEY, J. B; WOODWARD, D. (Ed.). The History of Cartography: Cartography in pre historic, ancient and medieval Europe and The Meditteranean. Chicago, London: The University of Chicago, 1984.

HOBSBAWM, E. Era dos extremos: o breve século XX 1914-1991. São Paulo: Companhia das Letras, 1995.

JIMENEZ, S. V.; MENDES SEGUNDO, M.D. Erradicar a pobreza e reproduzir o capital: notas críticas sobre as diretrizes para a educação do novo milênio. Cadernos de Educação: FaE/PPGE/UFPe, Pelotas, p.119-137, 2007. Disponível em :

<http://www2.ufpel.edu.br/fae/caduc/downloads/n28/artigo04.pdf> Acesso em : 19 mai. 2013. 
JOLY, F. A Cartografia. Campinas: Editora Papirus, 1990.

KANAKUBO, T. O desenvolvimento da Cartografia teórica contemporânea. Geocartografia, Geografia, USP, São Paulo, n. 4, p. 3-23, 1995.

KATUTA, A. M. Uso de mapas = alfabetização cartográfica e/ou leiturização cartográfica? Nuances: Revista do curso de pedagogia, Presidente Prudente, v. 3, n. 3, p. 41-46, 1997.

KATUTA, A. M. A linguagem Cartográfica no Ensino Superior e Básico. In: PONTUSCKHA, N. N.; OLIVEIRA, A. U. Geografia em Perspectiva: ensino e pesquisa. São Paulo: Contexto, 2010.

KOLÁČNÝ, A. Informação cartográfica: conceitos e termos fundamentais na Cartografia moderna. Geocartografia, Geografia, USP, São Paulo, n. 2, p. 311, 1994.

KRAAK, M.; ORMELING, F. Cartography: visualization of spatial data. New York: The Guilford Press. 2010.

KÜHN, T.S. A estrutura das revoluções científicas. São Paulo: Perspectiva, 1987.

LEÃO, V. P. A influência das diretrizes curriculares nacionais do Ministério da Educação e cultura para a formação de professores de Geografia da Educação Básica em nível superior. 2008. 96 f. Tese (Doutorado) - Departamento de Geografia, Universidade Federal de Minas Gerais, Belo Horizonte, 2008.

LEHER, R. Da ideologia do Desenvolvimento à Ideologia da Globalização: A Educação como Estratégia do Banco Mundial para o "Alívio" da Pobreza. 1998. Tese (Doutorado em Educação) - Faculdade de Educação, Universidade de São Paulo, 1998.

LEITE, M. E. Geotecnologias aplicadas ao mapeamento do uso do solo urbano e da dinâmica de favela em cidade média: o caso de Montes Claros/MG. 2011. Tese (Doutorado em Geografia) - Programa de PósGraduação em Geografia. Universidade Federal de Uberlândia, 2011.

LEITE, M. S.. Contribuições de Basil Bernstein e Yves Chevallard para a discussão do conhecimento escolar. 2004 Dissertação (Mestrado em Educação) - Departamento de Educação. Pontifícia Universidade Católica do Rio de Janeiro, 2004. Disponível em: <http://www.dbd.pucrio.br/pergamum/tesesabertas/0212105 04 pretextual.pdf>. Acesso em: 17 fev. 2013. 
LESANN, J. G. Documento cartográfico: considerações gerais. Revista Geografia \& Ensino, Belo Horizonte, v. 1, n. 3, p. 3-17, mar. 1983.

LESANN, J. G. Elaboração d'un matérial pédagogique pour l'apprentissage de notions géographiques de base, dans le classes primaires, au Brésil. 1989. Tese (Doutorado em Geografia). Paris: EHESS, 1989.

LESANN, Janine G. Do lápis à internet: reflexões sobre mudanças teóricometodológicas na elaboração de atlas escolares municipais. Boletim de Geografia, Maringá, v. 19, n. 2, p. 130-138, 2001.

LESANN, J.G. Geografia no Ensino Fundamental. Belo Horizonte: Argvmentvm, 2009.

LESANN, J. G. Metodologia para introduzir a Geografia no Ensino Fundamental. In. Almeida, R. D. Cartografia Escolar. São Paulo: Contexto, 2010.

LEWIS, G. M. The Origins of Cartography. In: Harley. J. B. \& David Woodward. The History of Cartography. Chicago: The University of Chicago Press, 1991.

LÜDKE, M.; ANDRÉ, M. E. D. A. Pesquisa em educação: abordagens qualitativas. São Paulo: EPU, 1986.

MACEACHREN, A. M; KRAAK, M. J. Research Challenges in Geovisualization. Cartography and Geographic Information Science, v. 28, n. 1, 2001. Disponível em < http://people.plan.aau.dk/ lbo/SIM/visagenda.pdf > Acesso em 21 dez 2013.

MARANGON, C.; LIMA, E. PEDAGOGIA: Philippe Perrenoud. Revista Educar para crescer. 2002. Disponível em:

<http://educarparacrescer.abril.com.br/aprendizagem/materias_296368.shtml> .Acesso em 16 fev. 2014.

MARTINELLI, Marcello. Gráficos e mapas: construa-os você mesmo. São Paulo: Moderna, 1998.

MARTINELLI, M. As representações gráficas da geografia: os mapas temáticos. São Paulo: Edição do autor, 1999.

MARTINELLI, M.; PASSINI, E. Y.; ALMEIDA, R. D. A cartografia para crianças: alfabetização, educação ou iniciação cartográfica? Boletim de Geografia, Maringá, v. 17, p. 125-136, 1999.

MARTINELLI, M.. Cartografia Temática: Caderno de Mapas. São Paulo: Editora da Universidade de São Paulo, 2003. 
MARTINELLI, M. Cartografia dinâmica: espaço e tempo nos mapas. Geousp, v. 18, p. 53-66, 2005.

MARTINELLI, M. A sistematização da Cartografia temática. In: ALMEIDA, R. D. Cartografia Escolar. São Paulo: Contexto, 2010.

MARTINELLI, M. Mapas da geografia e cartografia temática. São Paulo: Editora Contexto, 2013.

MARTINS, A. S. A reconfiguração da educação mineira nos anos 90: determinantes da política de formação em serviço de professores do Ensino Fundamental. In: CONGRESSO DE CIÊNCIAS HUMANAS, LETRAS E ARTES, 4., 1999, Viçosa. Atas... 1 CD-ROM. Viçosa: UFV, 02-06/ago./1999.

MATIAS, L. F. Por uma Cartografia Geográfica - Uma Análise da Representação Gráfica na Geografia. 1996. Dissertação (Mestrado em Geografia) - São Paulo: Faculdade de Filosofia Letras e Ciências Humanas, 1996.

MELO, I. B. N. Proposição de uma Cartografia Escolar no Ensino Superior. 2007. Tese (Doutorado em Geografia) - Rio Claro (SP): Universidade Estadual Paulista, 2007. Disponível em:

$<$ http://acervodigital.unesp.br/handle/123456789/52255?locale=pt_BR >. Acesso em: 17 abr. 2013.

MINAS GERAIS. Secretaria de Estado de Educação. Proposta curricular: CBC Geografia, Ensino Fundamental e Médio. 2005. Disponível em: < http://crv.educacao.mg.gov.br/aveonline40/banco_objetos_crv/\%7B395C848A2413-4144-841E-0C7A369344FD\%7D_PROJETO\%20GEOGRAFIA.pdf >. Acesso em: 24 mai. 2012.

MINAS GERAIS. Universidade Estadual De Montes Claros. Projeto Político Pedagógico: Curso de Licenciatura em Geografia. Montes Claros: UNIMONTES, 2002.

MINAS GERAIS. Universidade Estadual De Montes Claros. Projeto Político Pedagógico: Curso de Licenciatura em Geografia. Montes Claros: UNIMONTES, 2004.

MINAS GERAIS. Universidade Estadual De Montes Claros. Projeto Político Pedagógico: Curso de Licenciatura em Geografia. Montes Claros: UNIMONTES, 2008.

MINAYO, M. C. S.; DESLANDES, S. F.; CRUZ NETO, O.; GOMES, R. Pesquisa social: teoria, método e criatividade. Petrópolis, RJ: Vozes, 1994.

MIRANDA, M. E. Contribuição ao debate atual sobre a formação de professores no Brasil: pela formação de futuras gerações na perspectiva da reconstrução do sócio-cultural. Revista do Departamento de Geografia, 
Faculdade de Filosofia Letras e Ciências Humanas, Universidade de São Paulo, São Paulo, 20 (2010) 11-22 . Disponível em < http://citrus.uspnet.usp.br/rdg/ojs/index.php/rdg/article/viewFile/3/107 >. Acesso em: 21 jan. 2014.

MORAES, L. B. A. Cartografia na formação do professor de Geografia. Contribuições da Teoria do Ensino Desenvolvimental. 2014. Tese (Doutorado em Geografia) - Faculdade de Filosofia Letras e Ciências Humanas, Universidade de São Paulo, 2014.

MOREIRA, A. F. B. Currículo, utopia e pós-modernidade. In: MOREIRA, A. F. B (Orgs.). Currículo: questões atuais. Campinas: Papirus, 2008

MOREIRA, A. F. B... A psicologia... e o resto: o currículo segundo Cesar Coll. CAD. Pesq. N 100, p. 93-107, mar. 1997. Disponível em $<$ http://educa.fcc.org.br/scielo.php?script=sci arttext\&pid=S0100-

15741997000100006\&lng=pt\&nrm=iso >. Acesso em: 17 jan. 2014.

MUSSALIM; F.; BENTES, A. C. Introdução à linguística: domínio e fronteiras. São Paulo: Cortez, 2005.

NOGUEIRA, Ruth E. Cartografia: representação, comunicação e visualização de dados espaciais. Florianópolis: Editora da UFSC, 2009.

NOGUEIRA, Ruth Emilia. A disciplina de Cartografia Escolar na Universidade. Revista Brasileira de Cartografia, n. 63, Edição Especial 40 Anos. Rio de Janeiro: IBGE, 2011. Disponível em: < http://www.Isie.unb.br/rbc/index.php/rbc/article/view/353/343>. Acesso em: 17 nov. 2013.

NOVAES, A. R. Um mapa do tráfico de drogas no livro didático: encontros e desencontros entre geografia escolar e cartografia midiática. Revista Geograficidade, v. 2, Número Especial, Primavera 2012.

NUNES. José Jesús Reyes. Smartphone-based school atlases? In: Cartographica, 48:2, 2013, p. $126-133$.

OLIVEIRA, L. Estudo metodológico e cognitivo do mapa. 1978. 128 f. Tese (Livre Docência) - Universidade de São Paulo, São Paulo, 1978.

OLIVEIRA, Cêurio de. Dicionário cartográfico. Rio de Janeiro: IBGE, 1993.

OLIVEIRA, D. A. A educação básica na lei de diretrizes e bases da Educação Nacional: breve balanço sobre a organização escolar e o trabalho docente. In: SOUZA, João Valdir Alves de (Org.). Formação de Professores para a Educação Básica: dez anos da LDB. Belo Horizonte: Autêntica, 2007.

OLIVEIRA, Lívia de. Estudo Metodológico e Cognitivo do Mapa. In: ALMEIDA, Rosângela Doin. Cartografia Escolar. São Paulo: Contexto, 2010. 
ORMELING. F. J. Professor K A Salichtchev: Honorary Fellow Of The ICA International Institute for Aerial Survey and Earth Sciences. The Canadian Cartographer, v. 15, n. 2, dec., 1978.p. 100-104. Disponível em:

< http://utpjournals.metapress.com/content/G6381632876V53H3>. Acesso em: 03 set. 2013.

PAGANELLI, Tomoko Y. Para a construção do espaço geográfico na criança. 1982. Dissertação (Mestrado em Educação) - IESAE - Instituto de Estudos Avançados em Educação Rio de Janeiro: Fundação Getúlio Vargas, 1982. Disponível em:

< http://bibliotecadigital.fgv.br/dspace/handle/10438/9570>. Acesso em: 03 mar. 2011.

PASSINI, E. Y. A importância das representações gráficas no ensino da geografia. In: SCÄFFER, N. O. e outros. Ensinar e aprender geografia. Porto Alegre: AGB, 1998. p. 47-55.

PASSINI, E. Y.; MARTINELLI, M.; ALMEIDA, R. D. A cartografia para crianças: alfabetização, educação ou iniciação cartográfica? Boletim de Geografia, Maringá, v. 17, p. 125-136, 1999.

PASSINI, E. Y. Prática de Ensino de Geografia e estágio supervisionado. São Paulo: Contexto, 2007.

PEREIRA, A. M. Cidade média e região: o significado de Montes Claros no norte de Minas Gerais. 2007. Tese (Doutorado) - Programa de Pós-Graduação em Geografia, Universidade Federal de Uberlândia, 2007.

PERRENOUD, Philippe. Construir as competências desde a escola. Porto Alegre: Artmed, 1999.

PETCHENIK, B. B. Cognition in cartography. Cartographica. Monograph, 14):117-128, $1977 . \quad$ Disponível em: < http://www.mapcontext.com/autocarto/proceedings/auto-carto-2/pdf/cognitionin-cartography.pdf>. Acesso em: 17 fev. 2014.

PONTUSCHKA, N. N. Parâmetros Curriculares Nacionais: apenas a ponta de um iceberg. In: ENCONTRO NACIONAL DE PRÁTICA DE ENSINO EM GEOGRAFIA, 5., 1999, Belo Horizonte. Resumos. Belo Horizonte: Editora PUC Minas, 1999, p. 16-20.

PONTUSCHKA, N. N.; PAGANELLI, T.; CACETE, N. H. Para ensinar e aprender Geografia. São Paulo: Cortez, 2007.

PONTUSCKHA, N. N.; OLIVEIRA, A. U. de. Geografia em Perspectiva: ensino e pesquisa. São Paulo: Contexto, 2010.

QUEIROZ FILHO, A. P. RODRIGUES, M. A Arte de Voar em Mundos Virtuais. São Paulo: Annablume, 2007. 
QUEIROZ FILHO, A. P. Voo virtual: metáfora e representação cartográfica tridimensional. 2005. Tese (Doutorado em Engenharia) - Curso de Engenharia, Departamento de Departamento de Engenharia de Transportes, Universidade de São Paulo, São Paulo, 2005.

RAISZ, E. Cartografia Geral. Rio de Janeiro: Científica, 1969.

RAMOS, C. S. Visualização cartográfica e Cartografia Multimídia: conceitos e tecnologias. São Paulo: Editora da Unesp, 2005.

RICHTER, Denis. A Cartografia Escolar na Formação Inicial da Pedagogia. ENCONTRO NACIONAL DE DIDÁTICA E PRÁTICAS DE ENSINO, 16. ENDIPE Campinas: UNICAMP, 2012. Disponível em: <http://nepeg.com/newnepeg/wp-content/uploads/2014/04/RICHTER-DENIS.A-CARTOGRAFIA-ESCOLAR-NA-FORMA\%C3\%87\%C3\%83O-INICIAL-DAPEDAGOGIA-ENDIPE-CAMPINAS.pdf>. Acesso em: 24 set. 2013.

RIOS, R. B.; SOUZA, D. da C.; PORTUGAL, J. F.; OLIVEIRA, S. A cartografia no/do fazer pedagógico: saberes e praticas no espaço escolar. Geografia Ensino \& Pesquisa, v. 16, n.1, jan./jun.2012

ROBINSON, A. H. et al. Elements of Cartography. New York: John Wiley \& Sons, Inc., 1995.

ROSSI, M. A nova proposta curricular do ensino de Geografia na rede estadual de São Paulo: um estudo. 2011. Dissertação (Mestrado em Geografia) - Faculdade de Filosofia Letras e Ciências Humanas. Departamento de Geografia. Universidade de São Paulo, São Paulo, 2011.

RUA, João. O professor, o livro didático e a realidade vivida pelo aluno como recursos para o ensino da Geografia. Boletim Gaúcho de Geografia, Porto Alegre, maio de 1998, p. 87-95.

SAMPAIO, A. C. F. A Cartografia no ensino de licenciatura em Geografia: análise da estrutura curricular vigente no país, propostas na formação, perspectivas e desafios para o futuro professor - UFRJ. 2006. Tese (Doutorado em Geografia) - Instituto de Geociências, Universidade Federal do Rio de Janeiro, Rio de Janeiro, 2006.

SANTOS, B. de S. Pela mão de Alice: o social e o político na pósmodernidade. 7. ed. São Paulo: Cortez, 2000.

SANTOS, M. O Espaço do Cidadão. São Paulo: Editora da Universidade de São Paulo, 1987.

SAUSSURE, F. de. Curso de linguística geral. Tradução de Antônio Chelini, José Paulo Paes e Isidoro Blikstein. 28. ed. São Paulo: Cultrix, 2006. 
SCHON, D. Educando o Profissional Reflexivo: um novo design para o ensino e a aprendizagem Porto Alegre: Artmed Editora, 2000.

SEEMANN, Jorn. Mapas, Mapeamentos e a Cartografia Da Realidade. Revista Geografares, Vitória, n. 4, 2003. Disponível em:

$<\mathrm{https}: / /$ www.academia.edu/187818/MAPAS_MAPEAMENTOS_E_A_CARTOG RAFIA_DA_REALIDADE >. Acesso em: 10 nov. 2013.

SEEMANN, Jorn. Arte, conhecimento geográfico e leitura de imagens: $O$ geógrafo, de Vermeer. Pro-Posições, Campinas, v. 20, n. 3 (60), p. 43-60, set./dez. 2009a. Disponível em: <http://www.scielo.br/pdf/pp/v20n3/v20n3a04.pdf>. Acesso em: 23 set. 2013.

SEEMANN, Jorn. A Cartografia na Formação de Professores: Entre "CartoFatos" e "Cultura Cartográfica". In: COLÓQUIO DE CARTOGRAFIA PARA CRIANÇAS, 6.; FÓRUM LATINO-AMERICANO DE CARTOGRAFIA PARA ESCOLARES, 2., 2009. Juiz de Fora, Minas Gerais, 2009. Anais... Juiz de Fora, MG: 2009b.

SILVA, T. T. Documentos de Identidade: uma introdução às teorias do currículo. Belo Horizonte: Autêntica Editora, 2013.

SIMIÃO, H. C. R. Cartografia e Ensino de Geografia: Uma breve discussão teórico- metodológica. 2011. Dissertação (Mestrado em Geografia) Faculdade de Filosofia Letras e Ciências Humanas. Universidade de São Paulo, São Paulo, 2011.

SIMIELLI, M. E. R.. Coleção Primeiros Mapas: como entender e construir. São Paulo: Ed. Ática, 1993.

SIMIELLI, M. E. R.. O mapa como meio de comunicação: implicações no ensino da geografia do $1^{\circ}$ grau. 1986. 205 f. Tese (Doutorado em Geografia) Faculdade de Filosofia, Letras e Ciências Humanas da Universidade de São Paulo, São Paulo, 1986.

SIMIELLI, M. E. R. O mapa como meio de comunicação e a alfabetização cartográfica. In: ALMEIDA, R. D. Cartografia Escolar. São Paulo: Contexto, 2010.

SLUTER JUNIOR, R. S. New Theoretical Research Trends In Cartography. Revista Brasileira de Cartografia, n. 53, p. 29-37, dezembro, 2001.

SOARES, J. F. A avaliação educacional e a formação docente. In: SOUZA, J. V. A. de (Org.). Formação de professores para a educação básica: dez anos da LDB. Belo Horizonte: Autêntica, 2007.

SOUZA, J. V. A. de. Licenciaturas na UFMG: desafios, possibilidades e limites. In: SOUZA, J. V. A. de (Org.). Formação de professores para a educação básica: dez anos da LDB. Belo Horizonte: Autêntica, 2007. 
SOUZA, J. G. KATUTA, A. M. Geografia e conhecimentos cartográficos: a cartografia no movimento de renovação da geografia brasileira e a importância do uso de mapas. São Paulo: Editora UNESP, 2001.

TARDIF, Maurice. Saberes docentes e formação profissional. Petrópolis, RJ: Vozes, 2008.

TAYLOR, D. R. F. The Theory and Practice of Cybercartography: an introduction. In: TAYLOR, D. R. Fraser. Cybercartography: Theory and Practice. Amsterdam: Elsevier, 2007.

TOMMASI, L. D. Financiamento do Banco Mundial no setor educacional brasileiro. In: TOMMASI, L. D.; WARDE, M. J.; HADDAD, S (Orgs.).O BM e as políticas educacionais. São Paulo: Cortez, 1998.

VASCONCELLOS, R. A cartografia tátil e o deficiente visual: uma avaliação das etapas de produção e uso do mapa. 1993. Tese (Doutorado em Geografia) - Faculdade de Filosofia Letras e Ciências Humanas, Universidade de São Paulo, 1993.

VIEIRA, E.F.C. A utilização do bloco-diagrama na representação do relevo no $1^{\circ}$ ano do Ensino Médio. 2005. Dissertação (Mestrado). Programa de Pós Graduação em Geografia. Universidade Federal de Minas Gerais, 2005.

VIEIRA, E. F. C.; CASTRO, R. I. Cartografia: importância na formação do professor de geografia. In: ENCONTRO NACIONAL DE GEÓGRAFOS, 16., 2010. Crise, práxis e autonomia: espaços de resistência e de esperanças Espaço de Diálogos e Práticas, 2010, Porto Alegre. Anais... Porto Alegre, 2010.

YANAGUITA, A. I. Financiamento da educação no Brasil (1990-2010): Impactos No Padrão De Gestão Do Ensino Fundamental. 2013. Tese (Doutorado em Educação) - Universidade Estadual Paulista, Faculdade de Filosofia e Ciências, 2013.

ZUBA, J. A. G. Ensino de Geografia e formação dos professores das séries iniciais do Ensino Fundamental: das expectativas do Curso Normal Superior da UNIMONTES à realidade. 2006. 160 f. Dissertação (Mestrado em Geografia) - Instituto de Geografia, Universidade Federal de Uberlândia, Uberlândia, 2006.

ZUBA, J. A. G. A Formação do Professor de Geografia: uma discussão sobre as exigências locais e regionais do Norte de Minas. 2013. 202 f. Tese (Doutorado em Geografia) - Programa de Pós-Graduação em Geografia, Universidade Federal de Uberlândia, 2013. 


\section{APÊNDICES}

\section{APÊNDICE A: Questionário aplicado aos graduandos}

\section{Prezado Graduando,}

Este questionário é um dos instrumentos de coleta de dados de pesquisa denominada "Cartografia no ensino superior. discussão sobre a formação de professores a partir de um olhar sobre a Licenciatura em Geografia"

O objetivo das questões é permitir um diagnóstico do conhecimento dos acadêmicos do curso de Licenciatura em Geografia da Universidade Estadual de Montes Claros, verificando sua capacidade de leitura e interpretação de mapas bem como o nível de leitura.

Conto com sua colaboração. Agradecidamente,

$$
\begin{gathered}
\text { Eliane Ferreira Campos Vieira } \\
\text { Doutoranda } \\
\text { Programa de Pós Gradação em Geografia Humana } \\
\text { Universidade de São Paulo }
\end{gathered}
$$

\section{Atividade Diagnóstico}

Público alvo: acadêmicos de Geografia da UNIMONTES, que já cursaram as disciplinas Cartografia e Cartografia Temática.

1. Como você definiria a Cartografia?
2. O que você entende por alfabetização cartográfica?

3. Qual a importância da Cartografia na formação do futuro professor de Geografia?

4. O que é um mapa? Para que serve um mapa?

5. Nas disciplinas que você cursou ao longo da graduação excetuando aquelas estreitamente vinculadas à Cartografia, como os conhecimentos cartográficos foram abordados? De que forma?

6. Quais foram os principais conhecimentos construidos ao longo do curso sobre Cartografia Escolar?

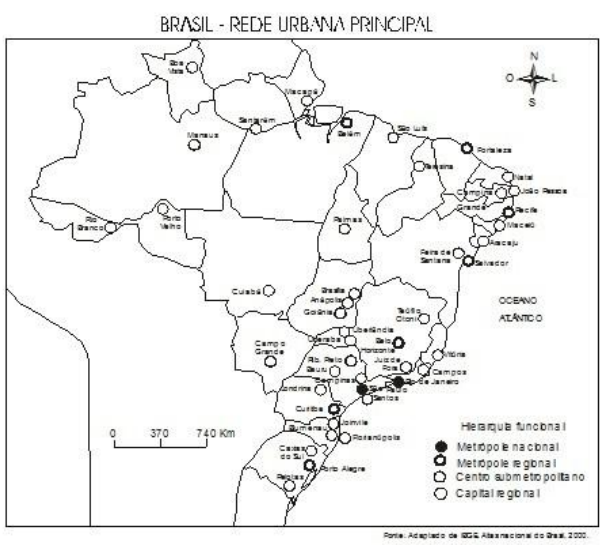

FONTE: Organizado por FELBEQUE, R. 


\section{APENDICE B - Respostas dos graduandos ao questionário}

\section{QUESTÃO 1 - Como você definiria a Cartografia?}

Q1. É a ciência que usa os mapas como seu objeto de estudo.

Q2. Linguagem geográfica, através de cartas, croquis e mapas, etc.

Q3. Cartografia é o estudo dos mapas.

Q4. Uma ciência muito antiga e de suma importância para a Geografia e áreas afins, onde através da técnica representa no papel ou no mapa a imagem próxima do real, etc.

Q5. Uma ciência de leitura do espaço geográfico.

Q6.Estudo dos mapas, produzir e interpretar

Q7. É estudo dos mapas.

Q8. É a área da Geografia que estuda os mapas, os fusos horários, e trata das questões de localização da Geografia.

Q9. Entendo como análise, interpretação e leitura de mapas. Na cartografia podemos identificar, colorir o mapa.

Q10. Ciência que reproduz o espaço através do mapa. Representação do meio, variando o tipo de abordagem, ou seja, vários tipos de temas.

Q11.Uma ciência que define a localização do espaço geográfico.

Q12. É o ramo da ciência geográfica que estuda a estrutura de mapas.

Q13. É a representação (o desenho) de uma paisagem como de um relevo, um território, do espaço físico.

Q14. Um espaço e território a ser demarcado.

Q.15 Eu definiria como o estudo do espaço terrestre.

Q.16 A cartografia é a ciência que estuda a representação cartográfica do espaço terrestre.

Q.17. Ciência matemática que busca criar e compreender as cartas.

Q18. A cartografia é muito importante para os cidadãos, pois a partir dela que espacializamos 0 mundo. Mapas, gráficos, tabelas, croquis, maquetes, imagens de satélite.

Q19.Estudo de mapas.

Q20. É o estudo dos diferentes espaços da Terra. Estes são representados através de desenhos, principalmente de mapas. Exemplos: ambientes aquáticos como rios e ambientes terrestres como áreas urbanas e rurais.

Q21. Uma área da Geografia que estuda as projeções do mapa.

Q22.É a ciência que representa determinado espaço em desenho.

Q23. Sistema gráfico que representa o espaço em escala de papel, trazendo facilidades em relação ao estudo do espaço.

Q24. Divisão da Geografia que se foca na espacialização do real em mapas.

Q25. A ciência que estuda e representa o espaço através de mapas.

Q26. E a ciência que estuda a representação cartográfica da superfície terrestre.

Q27. E um estudo que permite interpretar mapas, croquis e cartas.

Q28. E a ciência que estuda e descreve a superfície terrestre através de gráficos, mapas e outros.

Q29. Estudo sobre os mapas e suas devidas regiões, como fuso horários, coordenadas geográficas.

Q30. Estudo dos mapas.

Q31. Disciplina que serve para analisar dados matemáticos, mapas entre outros.

Q32. É o estudo dos mapas tendo como base os azimutes e rumos, em fazer uma análise de um mapa, para calcular o desenvolvimento tanto urbano quanto rural.

Q33. A ciência que define a representação gráfica da superfície terrestre.

Q34. Estudo que ajuda a ler, produzir, interpretar, uma carta topográfica, mapas, croqui.

Q35. Estudo de mapas e localizações.

Q36. Cartografia é uma matéria que trabalha mapas, croquis, plantas e demais formas de representar o espaço.

Q37. Estudo do espaço sobre visão técnica em mapas, além de orientação sobre tempo e espaço.

Q38. É o estudo de mapas para conhecer melhor o território e suas relações.

Q39. É o estudo dos mapas e a relação dos territórios.

Q40. Uma disciplina de grande importância para uma melhor compreensão do espaço, representado pela cartografia para entender o dinamismo de vários aspectos. 
Q41. Métodos para que possamos entender melhor localização de continentes, países, cidades, bairros.

Q42. Estudo dos mapas, cartas topográficas, analisando os mapas cartográficos.

Q43. É um estudo de conhecimento aritmético, de conhecimento de mapas.

Q44. Quantitativa relacionada à Matemática.

Q45. Conhecimento do cosmos através de mapas.

Q46. Como uma ciência que procura representar o planeta Terra num plano, facilitando ao homem seu estudo e entendimento.

Q47. É a descrição da superfície terrestre através de forma, relevo e distâncias, através da utilização e reprodução de cartas.

Q48. Um dos conteúdos ou matérias base para o ensino da Geografia em sala de aula, para que a partir deste, os alunos e não alunos, possam trabalhar com mapas.

Q49. Dinamização de conteúdos que facilita o aprendizado.

Q50. Um dos campos da Geografia que estuda e analisa as representações da Terra de forma ilustrada e iconográfica.

Q51. Um disciplina dinâmica onde o acadêmico transforma seu conhecimento numa leitura visual.

Q52.Um campo da ciência geográfica que se ocupa da construção de mapas e de requisitos básicos para a localização.

Q53. Um ramo da ciência geográfica indispensável para o ser humano, pois esta estuda localização que é essencial para a vida humana.

Q54. Construção de cartas que sintetizam e facilitam a mensuração de dados.

Q55. Disciplina que ensina a descrever os mapas.

Q56. Ciência que estuda as várias faces da superfície terrestre.

Q57. Estudo no qual se tem por objetivo compreender a localização, escala e confecção de croqui.

Q58. Uma disciplina que auxilia o aluno a se localizar, através de mapas, GPS e outros meios.

Q59. Conteúdo que precisa ser abordado com melhor clareza no ensino médio e superior, assim poderia com clareza definir cartografia.

Q60. É um ramo da Geografia que permite aprender sobre os mapas, fusos horários, escala de mapas e etc.

Q61. É a ciência que estuda, define e caracteriza uma área, região ou espaço utilizado.

Q62. Estudo de mapas, gráficos e parâmetros que norteia essa área.

Q63. É a ciência que trata dos estudos e operações tanto científica ou técnica relacionada à elaboração e utilização das cartas ou mapas de acordo com determinado sistema de projeção e uma determinada escala.

\section{QUESTÃO 2 - 0 que você entende por alfabetização cartográfica?}

Q1. É o momento que o indivíduo aprende a entender o que o mapa representa.

Q2. A alfabetização cartográfica consiste em um aprendizado básico para trabalhos com dados cartográficos.

Q3. Seria uma melhor forma de tentar com que os alunos conheçam as áreas geográficas.

Q4. Ensinar o aluno como ler e entender o mapa bem como suas propriedades.

Q5. Um meio de aprendizagem que envolve a utilização dos mapas em sala de aula.

Q6. Ensinar o aluno para a produção e interpretação de mapas.

Q7. É um método utilizado para se compreender o espaço a partir da interpretação dos mapas.

Q8. É o aluno ter uma noção básica de cartografia. Ex.: Saber ler um mapa.

Q9. Na cartografia, entendo como alfabetização, porque em um mapa é possível fazer várias leituras, interpretação, ou seja, o mapa é onde podemos aprender ou ensinar algo.

Q10. É a capacidade de compreensão da informação que o mapa em questão representa.

Q11. É um meio de aprendizagem do espaço, seja lugar território, paisagem, etc.

Q12. É a repassagem do conhecimento da estrutura e conteúdos cartográficos.

Q13. É o ensinar de uma representação das diversas paisagens, o aluno tem que ter uma noção do espaço em que vive e saber representa-lo e localizá-lo.

Q14. De uma forma eficiente, para o seu desenvolvimento em mapeamento de forma satisfatória.

Q15. Estudo das cartas, localização, escala. 
Q16. Refere-se a entender os conceitos básicos para conseguir interpretar e produzir gráficos, assim como os mapas.

Q17. Estudo da localização, escala, cartas, fusos horários.

Q18. Alfabetização cartográfica é saber fazer uma leitura do mapa. Ao pegar um mapa ou tabela saber interpretar a imagem.

Q19. Uma forma de levar o aluno a conhecer o mundo através de mapas.

Q20. Alfabetizar é ensinar algo a alguém seja qual for o ensino desde que a intenção seja a de buscar melhorias. Assim alfabetização cartográfica é repassar conhecimento básico de cartografia à pessoas que não conhecem ou não entendem o que esta representa.

Q21. Quando o aluno, professor, consegue identificar e analisar o conteúdo gráfico dos mapas.

Q22. Ensinar como representar, como pensar e reproduzir um espaço.

Q23. Aprendizado básico com relação aos processos e técnicas de representação cartográfica.

Q24. O aprendizado de como se deve trabalhar com mapas.

Q25. É ensinar a entender a utilizar o mapa como representação de um determinado espaço de modo que todos entendam.

Q26. Entender conceitos básicos para conseguir interpretar e produzir gráficos bem como os mapas.

Q27. $\quad$ Ensinar a fazer uma interpretação clara de mapas e ter uma noção de espaço.

Q28. É o modo de ensinar a interpretar gráficos, mapas e outros conceitos ligados à cartografia.

Q29. É o estudo sobre mapas, extensão sobre região, localização.

Q30. Eu entendo que alfabetização cartográfica se trata da leitura de mapas, leitura cartográfica. É de observar o espaço geográfico de forma cartográfica.

Q31. Ensinamento de cartografia.

Q32. É a análise de mapas através dos dados dos IBGE, para fazer a contagem da população, taxa de natalidade, IDH, etc...

Q33. Conceitos básicos como escalas, localização, pesquisas para que se possa produzir certos dados cartográficos e mapas.

Q34. Forma de estudar os mapas, aprender detalhadamente como se faz um mapa, croqui.

Q35. Ter conhecimentos do espaço vivido e observado.

Q36. Alfabetização cartográfica para mim, é o ensinamento da Cartografia, é ensinar o indíviduo a interpretar o espaço através de mapas, plantas, cartas, croquis.

Q37. Saber fazer uma analise cartográfica em mapas, além de saber se localizar no espaço.

Q38. $\quad$ É o ensino de escalas, mapeamentos, localização que permitem a construção de dados cartográficos.

Q39. Conceitos básicos como escalas, localizações, pesquisas para que possamos produzir certos dados cartográficos.

Q40. Uma introdução a cartografia bem como o entendimento de legendas e escalas.

Q41. São os princípios de localização a ser ensinados para alguém leigo no assunto.

Q42. O ensino da leitura de mapas, orientação na superfície terrestre a diferença de horário no mundo.

Q43. Pois ela que aprendemos os mapas, testando os nossos conhecimentos.

Q44. Ter conhecimento de localização escala, leitura de mapas...

Q45. É a mínima condição possível de se identificar elementos disponíveis em mapas.

Q46. Aquela que pode ser compreendida através do ensino, através da orientação de mapas, cartas topográficas, curvas de nível, entre outros.

Q47. Entendimento de dados cartográficos, mapas e grande representação de espaços e fatos que pode ser entendido com mais facilidade através da alfabetização cartográfica.

Q48. Conhecimento cartográfico não de forma superficial mas sim com embasamento e considerável nível interpretativo das representações.

Q49. Saber fazer uma leitura correta das informações contidas nos mapas cartográficos. 
Q50. Conhecimentos básicos, necessários da disciplina.

Q51. Alfabetização cartográfica é o conhecimento sobre os mapas e características geomorfológicas.

Q52. Na alfabetização cartográfica é a fase onde é iniciada os primeiros estudos relacionados com a cartografia e a sua localização.

Q53. Alfabetização cartográfica é uma introdução da cartografia, é o início da aprendizagem do conteúdo.

Q54. Alfabetização cartográfica é o ensino da Cartografia, o ensino da leitura e interpretação dos mapas, criação de mapas.

Q55. Seria o ensino passo a passo de mapas, de forma simples e clara, para melhor entendimento.

Q56. O início para entender o conteúdo de cartografia nas escolas do ensino básico.

Q57. Noções básicas da construção e configuração de mapas e cartas topográficas.

Q58. Entendo como alfabetização cartográfica, quando o aluno consegue entender o que o mapa tenta passar.

Q59. Ensino da Cartografia para os mais variados tipos de alunos (acadêmicos, professores e alunos da escola básica).

Q60. Aprendizado da Cartografia. Aprender a utilizar suas técnicas corretamente.

Q61. Um meio de identificar se o aluno sabe se identificar.

Q62. Não respondeu.

Q63. Alfabetização cartográfica é você saber ler um mapa, por exemplo, identificar a sua característica, o estado onde você mora e etc.

\section{QUESTÃO 3 - Qual e a importância da cartografia na formação do futuro professor de geografia?}

Q1. A cartografia é importante pois aproxima o público ao tema trabalhado pelo professor, pois torna as informações mais visíveis.

Q2. A cartografia é de grande importância na formação dos futuros professores, através dela desenvolvem-se habilidades de observação e espacialização que são fundamentais para a Geografia.

Q3. A importância da Cartografia para a formação do professor de Geografia é que ensina os mesmos a fazer seus próprios mapas para que trabalhem de forma mais interessante em sala de aula.

Q4. É de suma importância, pois a cartografia está muito ligada à Geografia principalmente para o emprego de novas tecnologias que vem revolucionando esta ciência.

Q5. De fundamental importância, pois através da cartografia nos localizamos espacialmente.

Q6. É um importante recurso didático que deve auxiliar o professor nas aulas de Geografia quase que em todos os conteúdos presentes na disciplina.

Q7. Auxilia o professor a delimitar áreas e repassar ao aluno uma melhor forma de aprendizado.

Q8. Ela é muito importante pois se constitui em uma das bases do ensino da Geografia. Se o futuro professor não aprende cartografia por consequência não saberá ensinar ao aluno.

Q9. É importante porque é uma base que temos para poder ensinar Geografia. Pois ensinar geografia sem mapa não é Geografia. É um pilar no ensino de Geografia.

Q10. A cartografia é uma base para o professsor tem de trabalhar o meio estudado. $\mathrm{Na}$ representação cartográfica pode-se colocar todas as informações de forma a "espacionalizar" ou regionalizar.

Q11. É importante porque a Cartografia é eficaz para a leitura do espaço com um todo, localização, posicionamento, etc.

Q12. Ensina a analisar o espaço sobre uma representação simbólica.

Q13. O mapa que é o principal instrumento da Geografia é uma leitura do espaço físico.

Q14. Importante frisar que um geógrafo se baseia na cartografia, a certo olhar em geral a cartografia é um sobrenome do geógrafo.

Q15. E importante para ajudar os alunos a trabalhar com mais facilidade as cartas.

Q16. A cartografia é de grande importância na formação do professor pois a partir dela pode produzir mapas e interpretá-los, usando ele como ferramenta de ensino para os alunos.

Q17. Saber lidar com as cartas (mapas), para que o aluno tenha mais facilidade de entender o conteúdo. 
Q18. A cartografia é um conteúdo mais importante da Geografia, pois através dela conseguimos fazer uma leitura do espaço geográfico.

Q19. É muito grande pois atraves da cartografia o professor tem uma diversidade para uma aula mais atraente.

Q20. A cartografia e de suma importância, pois é a base para todos os conteúdos ministrados por um professor de Geografia. Através desta é possível situar o aluno no espaço que será analisado, melhorando sua compreensão.

Q21. De grande importância, pois o estudo da cartografia é visto como difícil e de pouca importância onde os alunos tem muita dificuldade. Se o professor é preparado e for dinâmico suas aulas, grande parte das dificuldades seriam sanadas.

Q22. É de grande importância pois a representação cartográfica é a base do estudo da Geografia.

Q23. Principalmente como habilidade didática para transmissão do conhecimento do espaço.

Q24. Total importância, principalmente no que tange a renovação da didática.

Q25. Cartografia é a base da Geografia, através dela é possível ensinar qualquer conteúdo da Geografia.

Q26. A cartografia é de fundamental importância pois é através dela que interpretamos e produzimos os mapas e gráficos, que é a forma que utilizamos para representar o espaço geográfico.

Q27. É de fundamental importância para identificar o espaço e conhecer de forma clara.

Q28. Analisar mapas, ter mais visão geográfica.

Q29. A cartografia é o coração da Geografia. Sem a cartografia não há como explica o conteúdo e tudo que o aluno precisa para localizar as regiões dos diversos países do mundo como por exemplo, o horário, suas extensões.

Q30. Aprender a lidar com mapas, conhecer o espaço geográfico através das representações cartográficas, os mapas.

Q31. A Cartografia é de grande importância na formação de um professor pois nela aprendemos a confeccionar mapas, escalas, aprendemos medir e utilizar o espaço e futuramente passaremos esses conhecimentos para os alunos.

Q32. E a base para entender a análise de um mapa, legenda, localização de uma determinada região no Brasil.

Q33. É de grande importância pois esclarece a localização do espaço em que se vive, é uma forma muito estudada pois é o melhor jeito de se desenhar os mapas com suas escalas e índices apontados em alguma pesquisa.

Q34. De grande importância, pois nos ajuda a interpretar a saber passar e ensinar todas as informações que encontramos em um mapa.

Q35. O conhecimento do espaço em que vivemos.

Q36. Não posso imaginar um curso de Geografia sem cartografia, pois é uma matéria de base para os futuros professores de Geografia, pois nessa matéria é trabalhada tudo o que iremos ensinar em sala de aula como por exemplo, mapas, orientação, fuso horário, escalas, coordenadas geográficas dentre outras.

Q37. A cartografia é de suma importância em conhecer, localizar e situar o espaço, sendo que tal matéria faz-se uso contínuo para melhor entender o espaço.

Q38. A importância da Cartografia na formação do professor é importante para saber localizar as representações e descrições aos lugares e poder repassar seus conhecimentos como futuros professores.

Q39. Sem a cartografia o professor não conseguirá mostrar para seus alunos diversas regiões do mundo, sua extensão e também os fusos e várias outras importantes informações.

Q40. As representações cartográficas são de suma importância para o melhor entendimento do conteúdo, pela observação do espaço e de elementos representados.

Q41. Para que o futuro professor tenha habilidades e métodos cartográficos para ensinar seus alunos com segurança.

Q42. É a base do professor, no quesito de orientação do mundo.

Q43. É muito importante, onde o professor passa o conhecimento geográfico e a importância da matéria para o nosso viver.

Q44. Amplia o conhecimento de mapas, conhecendo o conteúdo.

Q45. Facilita o meio de comunicação através do ensino aos alunos. 
Q46. Suma importância pois os conhecimentos cartográficos são utilizados em todos os conteúdos da Geografia, portanto faz-se necessário que o professor de Geografia esteja bem instruído.

Q47. É de muita importância pois ela dá condições para o futuro professor ensinar a cartografia inicial na educação básica.

Q48. E de grande importância, para que o mesmo possa trabalhar com a Cartografia, na sala de aula.

Q49. Pode-se dizer que possivelmente não possa haver professor de Geografia em completa abrangência de conhecimentos sem a cartografia por isso é imprescindível a Cartografia.

Q50. Ter em mente a representação do planeta, com seus limites e características regionais ou territoriais.

Q51. É de suma importância pois o professor de Geografia necessita de uma boa compreensão cartográfica.

Q52. A importância para o conhecimento e formação diversificada.

Q53. É importante para saber os métodos utilizados em mapas e legendas e os aspectos regionais.

Q54. A cartografia é de suma importância na formação do futuro professor de Geografia, para que este possa repassar aos seus alunos o que tiver aprendido.

Q55. Quando o conteúdo é bem abordado no nível superior tal pode ser utilizado com eficiência no ensino básico e não deixar que o professor aprenda o conteúdo sozinho.

Q56. Extremamente importante pois é através dela que se consegue levar até o aluno a compreensão de mapas. Auxilia na transmissão dos conteúdos de região dos alunos.

Q57. A cartografia é o norte direcionador do professor de geografia, sem ela ele não tem autonomia para ensinar por exemplo coordenadas geográficas.

Q58. É de grande importância uma vez que em sala de aula utilizaremos a cartografia em muitos conteúdos em salas de aula. Além de quando bem utilizada esta ferramenta torna as aulas de geografia mais prazerosas.

Q59. Um professor de geografia é o responsável por ensinar ao aluno cartografia.

Q60. É importante porque é através da cartografia que o futuro professor poderá repassar melhor os ensinamentos sobre mapas, fuso horário e etc aos alunos da Educação básica.

Q61. De fundamental importância pois a leitura e interpretação dos mapas além de ajudarem a dar uma aula interativa e participativa chama a atenção dos alunos quando se trata de mapas criativos e interessantes e para que isso aconteça é necessário que faça uma boa leitura.

Q62. Total importância. Pois será necessário conhecer sobre o assunto para se ensinar, e também para compreender outros assuntos da Geografia.

Q63. Na minha perspectiva a cartografia tinha que acompanhar com os 5 elementos básicos sendo eles lugar, espaço, paisagem, região, território pois sem a cartografia não há como compreende-los.

\section{QUESTÃO 4 - $O$ que é um mapa? Para que serve um mapa?}

Q1. Mapa é uma representação de dados e serve para facilitar a compreensão do tema relacionado.

Q2. Um mapa é uma representação gráfica de determinado espaço físico. O mapa tem diversas finalidades (localizar, regionalizar, espacializar) entre outros.

Q3. Mapa é uma representação simbólica de um espaço geográfico. Serve para se conhecer uma determinada área.

Q4. É a representação do espaço real no papel, porém em forma de símbolos, legenda, etc. O mapa serve desde localização, didática, representar territórios.

Q5. Um desenho que tem uma escala e um título. Serve para uma localização espacial e uma apresentação de dados.

Q6. Representação de um determinado local/espaço. O mapa é um meio de se localizar.

Q7. O mapa é a representação de um todo em uma escala maior, transforma real colocando no papel.Serve para delimitar áreas.

Q8. O mapa é uma carta de localização. Ele tem várias utilidades, isso vai depender da finalidade do pesquisador. 
Q9. O mapa é uma representação gráfica na Cartografia. E ainda define a localização de algo a ser explicado ou entendido. O mapa serve para ensinar a geografia, possui várias finalidades, depende do pesquisador ou educador.

Q10. E a representação de um espaço. Seria para abordar características peculiares das regiões abordada como População, características naturais, divisões políticas e regionais.

Q11. O mapa é um desenho que termina com escala, título ou seja N, S, E W, ou seja localização específica.

Q12. É a representação simbólica da esfera local. Serve para localização geográfica.

Q13. É um desenho do meio físico, como relevo, hidrografia, vegetação, solo, etc.

Q14. O que se define os pontos, fronteiras, espaço, territorialidade e serve justamente para ser monitorado subindo seus limites.

Q15. É a representação de um determinado espaço. Para ajudar na localização dos dados ou informações mais precisas.

Q16. Mapa pode ser definido como uma representação visual de um determinado espaço geográfico. Ele serve para representar um espaço geográfico, podendo realizar uma classificação, estudas os espaços, regiões.

Q17. Mapa é a representação de um determinado espaço, utilizando uma escala. Ele serve para mostrar países, regiões, bacias hidrográficas entre outros.

Q18. É uma representação de um espaço. Serve para localizar ou seja serve para fazer uma leitura de um determinado espaço geográfico.

Q19. É uma representação gráfica de um determinado local. Depende de seu tema se é um mapa, político dentre outros.

Q20. É a representação gráfica de um determinado espaço. Este serve para auxiliar a identificar pontos específicos, bem como características específicas, sejam elas políticas, sociais, econômicas, físicas, entre outras.

Q21. Mapa é um desenho com projeções cartográficas, que servem de representação do planeta em diversas áreas.

Q22. Um mapa é uma representação de um lugar. Serve para regionalizar determinado espaço ou tema a partir da visão do que é reproduzido.

Q23. Mapa é uma representação gráfica em escala reduzida de determinado espaço. Tem diversas funções: Militares, agrícolas, estratégicas, de estudo, etc.

Q24. Uma espacialização do real em um plano. Trabalhar todo o mundo em sala de aula.

Q25. É a representação do espaço no papel, usando a escala, para representar o espaço real.

Q26. Mapa é uma representação visual de um espaço geográfico ou de parte da superfície terrestre, o mapa serve para representar determinado espaço geográfico, que pode ser urbano, rural, físico, et.

Q27. Representação do espaço em escala reduzida. Serve para interpretação do espaço e fazer análise.

Q28. É a representação geográfica de algo. Serve como guia orientação.

Q29. O mapa é um desenho ilustrativo que traz em si todas as informações que buscamos como extensão localização.

Q30. Um mapa é a representação do espaço geográfico no papel. Um mapa é utilizado no estudo de vários setores deste espaço como : industrialização, distância, índice de desenvolvimento e outras.

Q31. Representação cartográfica do espaço e localização.

Q32. É para saber localizar um região clima, vegetação, solo, relevo, depressão, etc. Um mapa serve para localizar um estado, região, local, clima, tempo, porcentagem de uma população urbana e rural.

Q33. Um mapa é uma forma de se localizar, lugar, região, índices ou censos, como por exemplo, região mais habitada pode ser apontado no mapa e assim localizada com vários estudos.

Q34. Carta topográfica que analisa questões políticas, econômicas e culturais etc. Representação do espaço em escala cartográfica. Serve para colocar em desenho todas as informações que consegue obter de um determinado assunto.

Q35. E uma forma de representação do espaço, em escala reduzida, serve para identificar o espaço e demais elementos presentes em uma dada área.

Q36. Mapa é representação do espaço em escala reduzida. Serve para analises representação visual de uma região.

Q37. É uma forma de localizar lugares regiões, índices ou censos. O mapa seria para mostrar a localização de algo. 
Q38. É um representação gráfica de um espaço.

Q39. É uma forma representativa de um determinado espaço. Para poder ter localização.

Q40. É uma projeção cartográfica da superfície terrestre. O mapa serve para nos orientar na superfície terrestre.

Q41. É uma localização. Serve para identificar os lugares.

Q42. Um mapa é escala que representa o tamanho de um espaço, orientação do lugar (espaço).

Q43. O mapa é uma parte diminuída até cem vez em um pequeno papel com a finalidade de localizar o que quer encontrar.

Q44. Um mapa serve para representar as delimitações territoriais, culturais, serve para apresentar os dados coletados e visualizar informações de cunho econômico, físico entre outros.

Q45. Mapa é uma representação gráfica de um tema. Serve para se identificar e aprofundar e apontar resultados de pesquisas, deve conter título, legenda e fonte.

Q46. Podemos dizer que um mapa é uma imagem seja ela em qualquer formato, arquivo, que geralmente vem mostrar uma pesquisa, exemplo, mapa mundi, regiões do IBGE, entre outros dados, sejam eles populacionais ou não.

Q47. É uma linguagem que representa dados de pesquisa, o que facilita a representação de espaços, dados de pesquisas, e representações específicas.

Q48. O mapa é uma representação que pode ser usada tanto nas ciências geográficas como em qualquer outro campo de estudo. Uma vez que um mapa tem como função representar algo.

Q49. E uma representação cartográfica, serve para localização, determinação e representação dos lugares e regiões.

Q50. O mapa é uma representação cartográfica, que serve para oferecer dados de várias naturezas. Importante na representação e delimitação de uma determinada área.

Q51. Mapa é uma representação do lugar que se deseja estudar. Serve para informar os dados de cada região.

Q52. Mapa é uma representação cartográfica de um lugar ou região. Serve para localização e orientação.

Q53. Um mapa é um desenho técnico com dados de localização colocados em um papel e em computadores. Ele serve para localizar lugares.

Q54. Informações de lugares retidas somente em um papel e serve para esclarecer informações sobre os lugares e hoje estão bem fácil de entender quando informado no computador.

Q55. Mapas são uma síntese de informações técnicas para representações de regiões.

Q56. Um mapa é a descrição e delimitação de um território.

Q57. Um instrumento cartográfico, uma representação em escala definida de um determinado lugar, e sua função é de orientação.

Q58. Mapa é a representação de uma área, em escala menos que pode possuir várias características diferentes.

Q59. É uma representação do local que se deseja estudar.

Q60. Mapa é um mecanismo no qual encontramos informações a respeito do nosso país e ou mundo, ou seja, é onde temos os países, solo, hidrografia. Os mapas servem também para nos localizarmos caso tenhamos, por exemplo, um problema com GPS, sendo assim é de fundamental importância termos um mapa em mãos.

Q61. Mapa é uma representação cartográfica de uma determinada região ou espaço. O mapa serve para a localização e orientação geográfica.

Q62. Desenho cartográfico de determinado território geográfico. Para orientação geográfica, localização, conhecimento da área, e a partir disso se estudar outros aspectos.

Q63. O mapa é um registro iconográfico de uma determinada região, e serve para representar uma determinada área em uma perspectiva ou escala menor.

\section{QUESTÃO 5 - Nas disciplinas que você cursou ao longo da graduação, excetuando aquelas estreitamente vinculadas à Cartografia, como os conhecimentos cartográficos foram abordados? De que forma?}

Q1. Não respondeu

Q2. Os conhecimentos cartográficos foram abordados através da apresentação e discursão de gráficos e mapas.

Q3. Foram abordados de forma reduzida e foi através dos mapas. 
Q4. Foram abordados de forma simples. Foram associados sempre as disciplinas em questão por exemplo, migrações representada no mapa com o ponto de chegada e saída.

Q5. Como forma de aula expositiva e prática. Leitura de mapas e de gráficos.

Q6. Ao longo do curso tivemos a exposição de vários mapas (Clima, solo, vegetação, regiões, etc.)

Q7. As outras disciplinas usaram dos estudos cartográficos para delimitarem suas áreas de ensino, como áreas de maior ou tipos de vegetação, lugares secos, industrias com maior abrangência entre outros.

Q8. Foram abordados de forma reduzida e somente através de mapas.

Q9. Sim. Foi abordada de forma regular e realizada, alcançando seu objetivo.

Q10. De forma dinâmica e que ressaltava o assunto a ser tratado de forma clara.

Q11. Os conhecimentos foram abordados através de cálculos, gráficos manuais, noção de localização, trabalhando a cartografia antiga até atual.

Q12. Foram abordados através de mapas juntamente com o conteúdo.

Q13. Sim, por meio de mapas, gráficos, noção de localização.

Q14. De forma natural e proveitosa, com todo o mérito e materiais para tal desenvolvimento.

Q15. A cartografia foi representada utilizando de gráficos e mapas.

Q16. Não respondeu.

Q17. Sim. Através de mapas.

Q18. Sempre foram necessários, nem sempre foram trabalhados, assim como nem sempre foram compreendidos. Acredito que justamente pela falta de prática desde o ensino fundamental e médio e por este histórico, uma maior dificuldade do professor em lecionar essa disciplina.

Q19. Foram abordados de forma muito simples, com pouca dinâmica nada eficaz.

Q20. O ensino de cartografia na graduação é ineficaz e retrogrado. É sempre abordado de forma simplória e insuficiente.

Q21. Com referencia de espacialização. Usando em representações de lugares, situações, contextos históricos, que espacializam o estudo.

Q22. Através principalmente de mapas temáticos.

Q23. Foram pouco utilizados, com explicação de mapas, porém de forma supérflua.

Q24. Foram abordados para representar determinados espaços geográficos, através de gráficos e mapas, nas disciplinas climatologia, geografia urbana, geologia.

Q25. Foram abordados de forma bem clara e objetiva.

Q26. Uso de material didático, com bússolas, mapas diversos, trabalhos em equipe na prática.

Q27. Foram abordados através de mapas, de forma didática com textos sobre cartografia e atividades avaliativas.

Q28. De forma ilustrativa com mapas.

Q29. Para saber calcular os rumos e os azimutes, através da regra de 3 para fazer os cálculos cartográficos, e os fusos horários de um local para outro.

Q30. Foram abordados com ênfase de esclarecer dados demográficos, populações, localização de regiões e vários outros fatores que se estuda a cartografia.

Q31. De forma mais simples, sem muito detalhes, através de mapas.

Q32. No estudo de escalas, mapas com legendas.

Q33. Os conhecimentos cartográficos foram abordados de forma que o aluno já devia saber a matéria, sem se preocupar se ele aprendeu ou não a matéria.

Q34. De forma clara, expositiva, o professor nos ofereceu prática.

Q35. Foram abordados em aulas expositivas, com exercícios de fixação e aulas práticas.

Q36. Foram abordados com aulas expositivas, práticas, exercícios de fixação.

Q37. Utilização de mapas que requeriam uma interpretação.

Q38. Algumas aulas teóricas e outras fora da sala como realização de um mapa de uma praça.

Q39. Algumas aulas, foram ministradas foram da sala de aula, no campo, marcando praças.

Q40. Através de apostila, pesquisa e conhecimento.

Q41. Abordada através de mapas e gráficos, estatística, bússula, etc, para aulas descritivas.

Q42. Através de mapas, bussolas croquis.

Q43. Com leitura de mapas, criação de mapas sínteses.

Q44. Foram abordados através de trabalhos com mapas, estudo e compreensão dos mesmos.

Q45. Foram abordados de diversas maneiras, como por exemplo, curvas de nível em papeis vegetais, mapas trabalhados, slides, diversos cálculos, entregas de trabalhos, etc.

Q46. Foram abordados através de matérias que são utilizadas para representação cartográfica de maneira muito dinâmica. 
Q47. Foram abordadas de forma superficial, com um profissional que não possui formação nas ciências geográficas.

Q48. Através de leituras e exercícios dos mapas em sala de aula.

Q49. Através de leitura e confecção de mapas de várias naturezas.

Q50. Foram abordados de forma abrangente, com utilização de mapas e cartas cartográficas.

Q51. Através de aulas teóricas e práticas com auxilio de materiais didáticos e também do próprio uso do mapa mundi.

Q52. Foram abordados em forma de mapas, para fazer-nos localizações.

Q53. Foram abordados de forma precária, deficiente com poucas práticas e pobreza no conteúdo.

Q54. Na abordagem referente a regiões e localização.

Q55. Foi ensinado curvas de nível, a produzir gráficos, escala.

Q56. De forma geral, mas permitindo a compreensão da importância da cartografia para o ensino geográfico de modo geral.

Q57. Na construção de gráficos, no aprendizado de como utilizar escala. Uso de matemática para a confecção de mapas de curvas de nível.

Q58. Não foram abordados, pois até os professores sentem dificuldades na cartografia.

Q59. Não respondeu.

Q60. Foram abordados por meio da interpretação de mapas bem como regionalização e iconificação dos mesmos.

Q61. De várias formas.

Q62. Dentro de um todo, onde sempre se abordava aspectos da Cartografia. Desde mapas, rumo, escala, dentre diversos aspectos.

Q63. Simplesmente não foram abordados, a não ser na própria disciplina.

\section{QUESTÃO 6 - Quais foram os principais conhecimentos construídos ao longo do curso sobre Cartografia Escolar?}

Q1. Que a cartografia pode ser um meio de atrair a atenção dos alunos e que a maioria das informações podem ser transformadas em mapas onde será possível a visualização das informações e facilitar a compreensão.

Q2. Que é de grande importância trabalhar a linguagem dos mapas com os alunos.

Q3. O que eu observo é que existe uma grande dificuldade em se trabalhar a cartografia, e isso decorre da própria formação na área o que para mim seria péssimo.

Q4. Ler e interpretar um mapa, entender a escala e sua importância, projeções cartográficas, entre outros.

Q5. Conhecimento dos mapas e gráficos, orientação cartográfica e construção de mapas.

Q6. A utilização de mapas é um excelente recurso didático para a aprendizagem dos alunos do ensino médio e fundamental.

Q7. A questão hidrográfica e climática foram de maior persistência no decorrer do curso.

Q8. Que essa se constitui em uma das grandes dificuldades no ensino de Geografia, essa dificuldade vem da formação de professores.

Q9. Desde o início veio contribuindo para a minha formação, sendo o embasamento do ensino escolar.

Q10. Que a cartografia é fundamental para a representação e estudo do espaço e que muda constantemente.

Q11. Noção de localização geográfica.

Q12. Conhecimento sobre representação de mapas e suas estruturas.

Q13. Localização.

Q14. Regular, no meu ponto de vista teria que ter um aumento na grade curricular, para melhorar os conhecimentos.

Q15. Saber como faz para calcular os diferentes fusos horários, orientações.

Q16. Utilizando da análise de mapas, observação e interpretação.

Q17. Saber calcular a diferença de horas nos fusos horários distintos, calcular rumos e azimutes, orientação, utilizando bússola e rosa-dos-ventos.

Q18. Localização, fusos horários, coordenadas geográficas.

Q19. Não respondeu.

Q20. Vários, mas foram mais explorados na Geografia Física, como Geologia, hidrografia entre outros. 
Q21. Nos acadêmicos devemos conhecer a cartografia e dar aulas dinâmicas aos nossos alunos, sendo que as disciplinas cursadas na Universidade não deram base alguma.

Q22. Que pode ser uma disciplina bem trabalhada e dinâmica uma vez que é a base da Geografia.

Q23. Estudo de mapas, escala, cor, latitude, longitude, eixos, fusos horários.

Q24. A importância da Cartografia no Ensino Fundamental.

Q25. Na verdade aprendi apenas a Cartografia e não teve ações voltadas para a escola. Aprendendo a fazer mapas (pouco) e não a ensinar.

Q26. Análise de mapas bem como representação, interpretação e observação.

Q27. Os conhecimentos construídos foram localização de espaço, coordenadas geográficas interpretação de mapas.

Q28. Análise de mapas, interpretação, observação, detalhes.

Q29. A cartografia escolar é uma base para todas as respostas, a Cartografia compreende todo o processo para aprender sobre fuso horário coordenadas geográficas saber onde nasce o sol, onde se põe, a rosa dos ventos, os pontos colaterais e subcolaterais, latitudes e longitudes.

Q30. Escala, pontos cardeais e colaterais. Produção de mapas, regionalização, fuso horário e outros.

Q31. Longitude, latitude escala.

Q32. Fusos horários, azimutes, rumos, mapas, altitude e longitude, para saber o clima e a hora local e legal de um lugar.

Q33. Escalas, mapeamentos, curvas de nível, gráficos.

Q34. Fazer um mapa, saber se localizar, fazer um croqui.

Q35. Não respondeu.

Q36. Os conhecimentos foram a partir de mapas, orientação no espaço, coordenadas geográficas.

Q37. Localização, situar no tempo e espaço, coordenadas geográficas, analises de mapas e etc.

Q38. Escalas, mapeamentos, curvas de nível, gráficos, etc.

Q39. Escalas, mapeamentos, curvas de nível, gráficos.

Q40. Escalas e legendas.

Q41. Mapas, localização e escala.

Q42. Localização, fuso horário, coordenadas geográficas.

Q43. Azimute, curvas de nível, croquis, etc.

Q44. Pouco elemento sobre a cartografia, através na versão escolar.

Q45. Como mapear uma área.

Q46. Não obtive conhecimento sobre o assunto.

Q47. Práticas de ensino como se ensinar de maneira mais fácil compreensão da cartografia escolar, conteúdo capaz de se dar uma base cientifica para ensinar.

Q48. Que nem sempre aquilo que é retratado na faculdade, vai ocorrer na sala de aula, porque o ensino da Cartografia não é fácil, até porque vários alunos não sabem nem ler, quanto mais interpretar gráficos e mapas.

Q49. Apesar de parecer difícil se observarmos conseguimos entender e utilizar a cartografia em vários momentos do ensino e aprendizado.

Q50. Infelizmente sem aplicabilidade em escola regular.

Q51. Construção de mapas com papel vegetal, confecções de mapas mudo.

Q52. A importância desse aparato na formação de todos os alunos das séries iniciais até o ensino médio.

Q53. Conhecimento de mapas e curvas de nível.

Q54. Com aulas utilizando papel vegetal para elaborar mapas.

Q55. Pouco conhecimento, insatisfatório.

Q56. Pouco conhecimento, insatisfatório, sendo assim, conhecimento fraco.

Q57. Noção de regiões e espacialização.

Q58. Estudo das coordenadas (latitude, longitude) paralelos, meridianos, fusos horários, interpretação de mapas, rosa dos ventos, etc

Q59. Escala, localização, coordenadas geográficas.

Q60. Conceitos de localização, escala.

Q61. Conceitos de localização, escala. 
Q62. Os conhecimentos foram muitos, como estudo e orientação e localização de mapas, escalas, rumos entre outros.

Q63. Localização e escala, dessa forma poder estudar gráficos e de forma ampla o mapa mundi.

\section{QUESTÃO 7 - Observe os dois mapas a seguir e responda: a)Com base na linguagem da representação gráfica de Bertin, explique se há e qual seria a diferença entre os dois mapas?}

Q1. A diferença entre os mapas são as figuras representadas na legenda porem apesar das diferenças entre as figuras dos dois mapas as áreas e as características representadas são as mesmas.

Q2. O primeiro mapa faz uma analise do tipo de cidade em escala geral. $O 2^{\circ}$ faz a hierarquia funcional de cada cidade.

Q3. Não sei essa diferença, não conheço a representação citada acima.

Q4. Não compreendi.

Q5. Notei diferença nas formas da legenda. Uma é sobre tipos de cidades e outra sobre a hierarquia funcional.

Q6. Não respondeu.

Q7. Cores e formas no sumário para delimitar melhor as áreas, sendo $01^{\circ}$ de melhor interpretação.

Q8. Não conheço a representação gráfica de Bertin, por isso não sei usar os parâmetros de comparação dos dois mapas.

Q9. Não tenho conhecimento da representação gráfica de Bertin.

Q10. As únicas diferenças são os símbolos utilizados na legenda para representar as metrópoles e as suas elaborações feitas por pessoas diferentes.

Q11. A diferença está na legenda.

Q12. Não respondeu.

Q13. Não vejo diferença, assim analisando por pouco tempo.

Q14. Tipo de legenda título, tipos de cidades e as quais estão representadas.

Q15. A diferença está na ilustração e nas formas de como foram inseridas no mapa.

Q16. Há uma certa diferença nos mapas pois o 1ํas capitais são consideradas metrópole nacional e o $2^{\circ}$ somente São Paulo e Rio de Janeiro.

Q17. As diferenças estão apenas na legenda e na posição da escala e da rosa dos ventos.

Q18. A legenda a rosa dos ventos, a escala.

Q19. Não.

Q20. Há diferenças não no mapa, nem em sua escala, mas na forma de analisar suas características, baseando-se, por exemplo, em sua legenda.

Q21. Não respondeu.

Q22. Na minha visão não há diferença.

Q23. Principalmente as legendas (cores)

Q24. Diferença na legenda e na forma de identificação.

Q25. O 1ํmapa está mostrando quais são os tipos de cidades, enquanto o 2ำ mapa está mostrando a hierarquia das cidades.

Q26. Há uma diferença pois no 1ำ mapa ele considera várias capitais como metrópole nacional e já no $2^{\circ}$ consideram apenas Rio de Janeiro e São Paulo.

Q27. Os dois mapas estão diferentes: No primeiro a escala e a legenda estão corretos. No segundo a escala e a legenda estão numa posição incorreta.

Q28. O mapa 1 parece ser mais especificado, mais organizado.

Q29. O 10 mapa mostra os tipos da cidade e o $2^{\circ}$ mapa mostra a hierarquia funcional.

Q30. Os mapas estão com símbolos da legenda diferentes, a localização da escala direfe e um mapa está mais organizado que outro. O primeiro mapa está esteticamente mais correto.

Q31. Os dois mapas representam a principal rede urbana no Brasil. O 1 mapa representa os tipos de cidades, com uma legenda mais diversificada. O $2^{\circ}$ mapa representa a hierarquia funcional, com uma legenda simples.

Q32. É a diferença do crescimento do Brasil pela rede urbana. Principal tipos de cidade, metrópole nacional, regional, centro submetropolitano, capital, regional. 
Q33. Seria a diferença e assuntos abordados nas legendas e por serem organizados por autores diferentes.

Q34. Diferença está na escala, legenda e na rosa dos ventos que estão em posições e definições erradas. Estão em escala reduzida.

Q35. A única diferença que vejo é somente na representação da legenda, apesar das duas falarem da mesma coisa.

Q36.

Q37. Há diferença na linguagem por exemplo na legenda, e a sua representação no desenho, tem-se o mesmo significado porém com linguagem diferenciada de um para outro.

Q38. Visualmente a principal diferença na representação está na linguagem da legenda com mesmo sentido.

Q39. A diferença dos dois mapas está na maneira que foram representados em suas legendas.

Q40. Sim. O primeiro mostra os tipos de cidade e a segunda a hierarquia funcional.

Q41. Não sei quem é Bertin, mas percebo fontes e legendas diferentes.

Q42. Os símbolos da legenda.

Q43. A diferença está na formação do mapa, no comprimento do mapa.

Q44. As legendas e as indicações dos lugares.

Q45. Primeiro a legenda do primeiro mapa defina o estatística do país com mais fácil legenda, o segundo representa a mesma estatística mas se olhar pode errar ou confundir devido a legenda.

Q46. O 1ำ mapa está destacado com a legenda dando-nos o conhecimento.

Q47. Sim. Um representa os tipos de cidade e o outro a função das mesmas.

Q48. Ao meu ver, legendas diferentes.

Q49. Legendas diferentes.

Q50. Estrutura dos dados lançados.

Q51. Não há diferença entre os mapas mas sim nas legendas, onde uma define tipos de cidades e a outra hierarquia funcional.

Q52. A diferença está nos símbolos da legenda e nos autores dos mapas.

Q53. Existe diferença. O tipo de simbologia utilizada nas legendas são diferentes.

Q54. O segundo mapa está melhor de ser trabalhado.

Q55. O 2ํㅡㄹ mapa é de melhor visualização podendo ser melhor trabalhado.

Q56. Não respondeu.

Q57. A diferença está na forma de representação dos gráficos.

Q58. Há diferenças: um é um mapa por tipos de cidades e outro de hierarquia funcional.

Q59. As legendas.

Q60. Sim, a legenda do segundo mapa torna-o, melhor compreensível.

Q61. Ao meu ver a diferença está na legenda e nos símbolos utilizados.

Q62. A diferença são as legendas, uma aborda a hierarquia funcional, como a cidade funciona e o outro a cidade em si. Outro ponto é o tipo de organização de cada um.

Q63. O primeiro mapa é oficial do IBGE e o segundo é a realidade do desenvolvimento urbano.

\section{a) Qual dos dois mapas seria a melhor opção de representação para o tema e por quê?}

Q1. O segundo mapa tem a melhor representação pois as figuras são mais fáceis de diferenciação apesar de ter o mesmo formato.

Q2. O primeiro.

Q3. Acho que os dois trazem informações importantes.

Q4. O número 2 porque a rede urbana principal é destacado a hierarquia funcional e não os tipos de cidades.

Q5. O segundo mapa apresenta de forma mais explícita.

Q6. Não respondeu

Q7. O primeiro que utiliza na legenda cores mais fortes e diferentes formas geométricas.

Q8. Acredito que os dois trazem as mesmas informações, quanto qual será utilizado vai depender do gosto do professor. 
Q9. Os dois têm uma boa interpretação, isso depende da leitura de cada leitor. Mas acredito que o $1^{\circ}$ está melhor para ser interpretado, por causa da legenda que está mais fácil de ser compreendido.

Q10. O segundo mapa pois um ano mais recente.

Q11. O mapa 2 porque representa a hierarquia de cada região.

Q12. Não respondeu.

Q13. O mapa 2 pela legenda que fala da hierarquia funcional.

Q14. Neste se trata de um mapa mais político.

Q15. O primeiro pois está mais claro nas informações, faz o uso de uma linguagem mais simples.

Q16. O $2^{\circ}$ mapa representa melhor a área urbana.

Q17. A primeira, pois é mais utilizada.

Q18. A segunda imagem seria melhor. A legenda é mais fácil para identificar.

Q19. Os dois pois eles representam o mesmo assunto.

Q20. O segundo pois sua legenda diferenciada é mais representativa.

Q21. O mapa dos tipos de cidade, as representações estão mais visíveis no mapa.

Q22. O de Felbeque pois utiliza uma linguagem mais formal.

Q23. O primeiro mapa traz representações mais distintas na legenda e cores distintas.

Q24. O segundo pois possibilita uma interpretação mais fácil.

Q25. O 2o mapa, pois ele especifica a hierarquia das cidades, mostrando do maior nível para o menor.

Q26. O $2^{\circ}$ mapa pois melhor representa a rede urbana principal.

Q27. O primeiro mapa, porque está organizado e mais fácil de entender para fazer uma análise corretamente.

Q28. Mapa 1 por ser mais rico em detalhes mais colorido.

Q29. O primeiro porque mostra os tipos de cada metrópole e onde concentra mais cada um.

Q30. O primeiro mapa pois está mais organizado e esteticamente mais correto que facilita a compreensão.

Q31. O primeiro pois a legenda é composta por elementos diferentes.

Q32. O primeiro mapa apresenta dados do Brasil pela rede urbana principal através de dados do IBGE, que apresenta o desenvolvimento do IDH das cidades pelo avanço das regiões em aspectos nacionais, regionais, de infra-estrutura, saneamento, habitação, universidades, hospitais, educação, cultura, lazer, igrejas, etc.

Q33. O mapa 1 mostra melhor especificidade da legenda entre os tipos de cidade.

Q34. Mapa 1, pois as informações da legenda estão mais visíveis, a escala está de acordo com o proposto.

Q35. O segundo mapa por ser mais fácil de localizar no mapa, pois pode haver uma confusão na legenda do mapa 1.

Q36. NÃO TEM...

Q37. O primeiro mapa seria a melhor opção, devido a linguagem que o autor usou, a forma da representação passa mais informação.

Q38. Creio que o $1^{\circ}$ mapa pela linguagem clara e expressiva.

Q39. Mapa 1 pois apresenta uma diferenciação em sua legenda que facilita a compreensão do mapa, onde as cidades são apresentadas como formas geométricas diferenciadas.

Q40. O 1 mapa seria melhor pois ele especifica na legenda os tipos de cidades.

Q41. Não sei

Q42. O segundo, pois os símbolos são diferentes um do doutro, tendo assim uma melhor visualização.

Q43. O primeiro mapa, porque a legenda do primeiro é possível uma melhor compreensão dos dados do mapa.

Q44. 1 mapa, mais fácil entendimento e explicação detalhada das cidades.

Q45. O 1 tem melhor representação pois de fato traz um núcleo de rede da urbanização.

Q46. O 1o mapa por causa dos detalhes que há nele.

Q47. O mapa 2 porque ele representa melhor o tema pois a sua legenda traduz a importância funcional de cada cidade.

Q48. O segundo mapa, porque os símbolos do mapa, na legenda, estão em ordem crescente, de capital regional a metrópole nacional.

Q49. O segundo mapa devido a representação ser de forma crescente.

Q50. O primeiro mapa, a estrutura está mais organizada. 
Q51. Não há diferença pois os mapas representam uma só identidade.

Q52. O segundo, pois a legenda é mais nítida.

Q53. O mapa 1, pois a simbologia é de mais fácil compreensão, devido ser diferenciada por cada tipo de cor.

Q54. O segundo mapa.

Q55. $\bigcirc 2^{\circ}$ mapa com a legenda hierarquia funcional pode nos identificar a soberania de algumas cidades e dependências de outras sendo no comércio, na economia, política e transporte.

Q56. A legenda hierarquia do segundo mapa é mais fácil de ser compreendida, pois já norteia quem está lendo o mapa quanto a importância da cidade.

Q57. Na minha opinião o mapa 1, por causa da representação utilizada com a variação de forma geométrica que facilita a compreensão.

Q58. O segundo mapa porque há diferenciação usada, apesar dos mesmos símbolos, é mais fácil de compreender.

Q59. O segundo pois a sua legenda está mais adequada ao mapa, facilitando sua interpretação.

Q60. O segundo porque a legenda bem elaborada é de suma importância para a representação de um mapa.

Q61. Acredito que seria o primeiro porque a legenda tem cores que facilita a leitura do mapa.

Q62. Acho que os dois mapas são aptos para abordagem a questão proposta ou seja, os dois trazem as principais cidades as que têm mais influência sobre a outra.

Q63. O mapa 2 pois o tema da rede urbana principal e não a divisão estabelecida pelo IBGE. 
ANEXOS 
ANEXO A: Habilidades do domínio da Geografia ao longo do currículo do Ensino Fundamental I, segundo Lesann (2009)

\begin{tabular}{|c|c|c|c|c|c|}
\hline HABILIDADES & $1^{\circ} \mathrm{ANO}$ & $2^{\circ}$ ANO & $3^{\circ} \mathrm{ANO}$ & $4^{\circ} \mathrm{ANO}$ & $5^{\circ} \mathrm{ANO}$ \\
\hline $\begin{array}{l}\text { Habilidades para } \\
\text { preparar a aquisição de } \\
\text { dados }\end{array}$ & $\begin{array}{l}\text { Verbalizar percepções e } \\
\text { conhecimentos próprios } \\
\text { Formular pedidos sob forma } \\
\text { de perguntas formuladas } \\
\text { oralmente }\end{array}$ & $\begin{array}{l}\text { a) levantar percepções e } \\
\text { conhecimentos prévios } \\
\text { b) formular pedidos, sob forma de } \\
\text { perguntas registradas por escrito }\end{array}$ & $\begin{array}{l}\text { a) levantar percepções e } \\
\text { conhecimentos prévios } \\
\text { b) formular pedidos sob forma de } \\
\text { perguntas, registrados por escrito } \\
\text { c) formular questionamento do } \\
\text { interesse do aluno } \\
\text { d) formular perguntas para obter } \\
\text { respostas aos questionamentos } \\
\text { e) preparar uma pequena } \\
\text { entrevista com poucas perguntas } \\
\text { f) preparar um pequeno } \\
\text { questionário com poucas } \\
\text { perguntas a } \\
\text { g) formular objetivos para uma } \\
\text { pequena pesquisa }\end{array}$ & $\begin{array}{l}\text { a) levantar conhecimentos } \\
\text { prévios } \\
\text { b) formular pedidos, sob } \\
\text { forma de perguntas, } \\
\text { registradas por escrito } \\
\text { c) formular questionamentos } \\
\text { de interesse do aluno } \\
\text { d) formular perguntas para } \\
\text { obter respostas aos } \\
\text { questionamentos } \\
\text { e) preparar uma entrevista } \\
\text { f) preparar um questionário } \\
\text { g) formular objetivos para } \\
\text { uma pesquisa }\end{array}$ & $\begin{array}{l}\text { a) levantar conhecimentos } \\
\text { prévios } \\
\text { b) formular pedidos sob forma } \\
\text { de perguntas, registradas por } \\
\text { escrito } \\
\text { c) formular questionamentos de } \\
\text { interesse do aluno } \\
\text { d) formular perguntas para } \\
\text { obter respostas aos } \\
\text { questionamentos } \\
\text { e) preparar uma entrevista; } \\
\text { f) preparar um questionário } \\
\text { g) formular objetivos para uma } \\
\text { pesquisa }\end{array}$ \\
\hline $\begin{array}{l}\text { Habilidades } \\
\text { adquirir dados }\end{array}$ & $\begin{array}{l}\text { a) observar o espaço em que } \\
\text { se vive; } \\
\text { b) registrar as observações da } \\
\text { realidade por meio de } \\
\text { descrição oral, individual e } \\
\text { coletiva e por meio de } \\
\text { desenhos } \\
\text { c) ler fotografias e figuras. }\end{array}$ & $\begin{array}{l}\text { a) observar o espaço em que se } \\
\text { vive } \\
\text { b) registrar as observações por } \\
\text { meio de descrição oral, individual } \\
\text { e coletiva } \\
\text { c) registrar as observações da } \\
\text { realidade por meio de } \\
\text { representações } \\
\text { d) ler pequenos textos, quadros de } \\
\text { informações, fotografias }\end{array}$ & $\begin{array}{l}\text { a) observar o espaço em que se } \\
\text { vive } \\
\text { b) registrar as observações da } \\
\text { realidade por meio de } \\
\text { representações gráficas } \\
\text { c) ler pequenos textos, quadros } \\
\text { de informações, fotografias, } \\
\text { figuras, gráficos de curva e de } \\
\text { barras, mapas com um tema }\end{array}$ & $\begin{array}{l}\text { a) observar o espaço em que } \\
\text { se vive } \\
\text { b) registrar as observações da } \\
\text { realidade por meio de } \\
\text { representações gráficas } \\
\text { c) ler pequenos textos, } \\
\text { quadros de informações, } \\
\text { fotografias, figuras, gráficos de } \\
\text { curva e de barras, mapas, } \\
\text { climograma e pirâmide de } \\
\text { idade } \\
\text { d) analisar gráficos de linha, } \\
\text { de barras e setorial (pizza) e } \\
\text { mapas com um ou dois temas } \\
\text { e) analisar croquis e mapas } \\
\text { com um ou dois???, em Atlas } \\
\text { Escolar. }\end{array}$ & $\begin{array}{l}\text { a) observar o espaço em que se } \\
\text { vive } \\
\text { b) registrar as observações da } \\
\text { realidade por meio de } \\
\text { representações gráficas } \\
\text { c) ler pequenos textos, quadros de } \\
\text { informações, fotografias, figuras, } \\
\text { gráficos de curva e de barras, } \\
\text { mapas, climograma e pirâmide de } \\
\text { idade } \\
\text { d) analisar gráficos de linha, de } \\
\text { barras e setorial (pizza) e mapas } \\
\text { com um ou mais temas } \\
\text { e) analisar croquis e mapas com } \\
\text { um ou mais temas, em Atlas } \\
\text { Escolar }\end{array}$ \\
\hline $\begin{array}{l}\text { Habilidades para tratar } \\
\text { dados }\end{array}$ & $\begin{array}{l}\text { a) comparar objetos com } \\
\text { características diferentes e } \\
\text { semelhantes; } \\
\text { b) organizar e ordenar por } \\
\text { cores, tamanhos, espessuras } \\
\text { e formas }\end{array}$ & $\begin{array}{l}\text { a) comparar objetos com } \\
\text { características diferentes } \\
\text { semelhantes } \\
\text { b) organizar e ordenar por cores, } \\
\text { tamanhos, espessuras, } \\
\text { tonalidades e formas } \\
\text { c) ordenar objetos do maior para o } \\
\text { menor e inversamente }\end{array}$ & $\begin{array}{l}\text { a) comparar objetos com } \\
\text { características diferentes } \\
\text { semelhantes } \\
\text { b) organizar objetos por categoria } \\
\text { com um e mais critérios, em } \\
\text { quadro ou tabela } \\
\text { c) ordenar dados do maior para o } \\
\text { menor e inversamente }\end{array}$ & $\begin{array}{l}\text { a) comparar objetos e } \\
\text { elementos espaciais com } \\
\text { características diferentes e } \\
\text { semelhantes } \\
\text { b) ordenar dados do maior } \\
\text { para o menor e inversamente } \\
\text { c) organizar e classificar } \\
\text { dados por categoria com um e }\end{array}$ & $\begin{array}{l}\text { a) comparar objetos e elementos } \\
\text { espaciais com características } \\
\text { diferentes e semelhantes; } \\
\text { b) organizar e classificar dados } \\
\text { por categoria, com um e mais } \\
\text { critérios, em tabela } \\
\text { d) organizar informações por } \\
\text { categorias, em quadro }\end{array}$ \\
\hline
\end{tabular}




\begin{tabular}{|c|c|c|c|c|c|}
\hline & & $\begin{array}{l}\text { d) organizar objetos por categoria } \\
\text { com um e mais critérios }\end{array}$ & $\begin{array}{l}\text { d) organizar dados por categorias, } \\
\text { em tabelas de dados } \\
\text { e) comparar dados e informações }\end{array}$ & $\begin{array}{l}\text { mais critérios em tabela } \\
\text { d) organizar informações por } \\
\text { categorias, em quadro } \\
\text { e) comparar dados e } \\
\text { informações } \\
\text { f) escolher classes de dados } \\
\text { para representá-los numa } \\
\text { legenda de mapa }\end{array}$ & $\begin{array}{l}\text { e) comparar dados e informações } \\
\text { f) escolher classes de dados para } \\
\text { representá-los numa legenda de } \\
\text { mapa }\end{array}$ \\
\hline $\begin{array}{l}\text { Habilidades para } \\
\text { representar dados }\end{array}$ & $\begin{array}{l}\text { b) produzir desenhos livres } \\
\text { b) descrever oralmente a } \\
\text { realidade observada } \\
\text { c) organizar oralmente uma } \\
\text { história com lógica, a partir de } \\
\text { dados observados }\end{array}$ & $\begin{array}{l}\text { a) produzir desenhos livres } \\
\text { b) descrever oralmente a realidade } \\
\text { observada } \\
\text { c) construir gráficos de curva e de } \\
\text { barras com objetos, em maquete }\end{array}$ & $\begin{array}{l}\text { a) redigir pequenos textos } \\
\text { descritivos da realidade } \\
\text { observada; produzir desenhos } \\
\text { livres } \\
\text { b) descrever oralmente a } \\
\text { realidade observada } \\
\text { c) construir gráficos de curva e de } \\
\text { barras com objetos, em maquete }\end{array}$ & $\begin{array}{l}\text { a) redigir textos descritivos da } \\
\text { realidade observada } \\
\text { b) elaborar croquis e } \\
\text { esquemas } \\
\text { c) construir gráficos de curva, } \\
\text { de barras, climograma e } \\
\text { pirâmide de idade } \\
\text { d) construir legendas e mapas }\end{array}$ & $\begin{array}{l}\text { a) redigir textos descritivos da } \\
\text { realidade observada } \\
\text { b) elaborar croquis e esquemas } \\
\text { c) construir gráficos de curva, de } \\
\text { barras, climograma e pirâmide de } \\
\text { idade } \\
\text { d) construir legendas e mapas }\end{array}$ \\
\hline $\begin{array}{l}\text { Habilidades } \\
\text { entender }\end{array}$ & $\begin{array}{l}\text { a) localizar-se no espaço da } \\
\text { escola, por meio das noções } \\
\text { topológicas } \\
\text { b) reconhecer os principais } \\
\text { elementos do espaço } \\
\text { c) entender as divisões do } \\
\text { tempo durante um dia, na } \\
\text { escola }\end{array}$ & $\begin{array}{l}\text { a) localizar-se no espaço da } \\
\text { escola, por meio das noções } \\
\text { topológicas } \\
\text { b) localizar elementos e pessoas } \\
\text { no espaço da escola } \\
\text { c) entender o funcionamento da } \\
\text { escola para uso do aluno } \\
\text { d) identificar as funções dos } \\
\text { principais elementos do espaço } \\
\text { e) reconhecer os principais } \\
\text { elementos do espaço } \\
\text { f) entender o tempo numa } \\
\text { semana, na escola } \\
\text { g) comparar documentos diversos } \\
\text { h) analisar documentos diversos } \\
\text { i) medir com uma escala } \\
\text { perceptiva una }\end{array}$ & $\begin{array}{l}\text { a) localizar-se no espaço, por } \\
\text { meio das noções topológicas } \\
\text { b) localizar elementos e pessoas } \\
\text { no espaço, por meio das noções } \\
\text { topológicas } \\
\text { c) comparar documentos diversos } \\
\text { (croquis, gráficos, mapas e } \\
\text { tabelas simples com dados } \\
\text { estatísticos) } \\
\text { d) interpretar documentos } \\
\text { diversos (croquis, gráficos, mapas } \\
\text { e tabelas simples com dados } \\
\text { estatísticos) } \\
\text { e) entender a distribuição espacial } \\
\text { dos principais elementos do } \\
\text { espaço (escola, rua da escola) } \\
\text { f) entender a distribuição espacial } \\
\text { das funções dos principais } \\
\text { elementos do espaço } \\
\text { g) medir com a escala gráfica }\end{array}$ & $\begin{array}{l}\text { a) localizar-se no espaço em } \\
\text { diversas escalas } \\
\text { b) localizar elementos e } \\
\text { pessoas no espaço em } \\
\text { diversas escalas } \\
\text { c) entender a distribuição } \\
\text { espacial dos principais } \\
\text { elementos do espaço (bairros, } \\
\text { município) } \\
\text { d) entender a distribuição } \\
\text { espacial das funções dos } \\
\text { principais elementos do } \\
\text { espaço ino } \\
\text { e) interpretar documentos } \\
\text { diversos (croquis, gráficos, } \\
\text { mapas e tabelas simples com } \\
\text { dados estatísticos) } \\
\text { f) medir com a escala gráfica } \\
\text { g) compreender noções } \\
\text { relativas à população } \\
\text { h) interpretar informações }\end{array}$ & $\begin{array}{l}\text { a) localizar-se no espaço com a } \\
\text { lateralidade e os pontos cardeais } \\
\text { b) localizar elementos e pessoas } \\
\text { no espaço, com a lateralidade e } \\
\text { os pontos cardeais } \\
\text { c) entender a distribuição espacial } \\
\text { dos principais elementos do } \\
\text { espaço (município, estado) } \\
\text { d) entender a distribuição espacial } \\
\text { das funções dos principais } \\
\text { elementos do espaço } \\
\text { e) interpretar documentos diversos } \\
\text { (croquis, gráficos, mapas e } \\
\text { tabelas simples com dados } \\
\text { estatísticos) } \\
\text { f) orientar um mapa com os } \\
\text { pontos cardeais } \\
\text { g) medir com uma escala gráfica } \\
\text { h) compreender noções relativas à } \\
\text { população } \\
\text { h) interpretar informações }\end{array}$ \\
\hline
\end{tabular}

Fonte: Lesann (2009:69-75). (Adaptado pela autora). 
ANEXO B: Resumo do PCN do $3^{\circ}$ ciclo

\begin{tabular}{|c|c|c|}
\hline Eixo & Tema & Item \\
\hline \multirow[t]{2}{*}{$\begin{array}{l}\text { A Geografia } \\
\text { como uma } \\
\text { possibilidade } \\
\text { de leitura e de } \\
\text { compreensão } \\
\text { do } \\
\text { mundo }\end{array}$} & $\begin{array}{l}\text { A construção } \\
\text { do espaço: os } \\
\text { territórios e os } \\
\text { lugares (tempo } \\
\text { da sociedade e } \\
\text { tempo da } \\
\text { natureza) }\end{array}$ & $\begin{array}{l}\text { O trabalho e a apropriação da natureza na construção do } \\
\text { território. } \\
\text {. As mudanças nas relações sociais do trabalho e a separação } \\
\text { entre o campo e a cidade. } \\
\text {. As diferentes técnicas e costumes e a diversidade de paisagens } \\
\text { entre o campo e a cidade. } \\
\text { O ambiente natural e as diferentes formas de construção das } \\
\text { moradias no mundo: do iglu às tendas dos desertos. } \\
\text { O ambiente natural e a diversidade das paisagens agrárias no } \\
\text { mundo: da coleta nas florestas à irrigação nas áreas semiáridas e } \\
\text { desérticas. } \\
\text { Os ritmos da natureza no processo de produção das condições } \\
\text { materiais e da organização social de vida no campo e na cidade. } \\
\text { O ritmo de trabalho: aceleração e desaceleração na produção } \\
\text { do campo e da cidade. }\end{array}$ \\
\hline & $\begin{array}{lr}\text { A conquista do } \\
\text { lugar } & \text { como } \\
\text { conquista } & \text { da } \\
\text { cidadania } & \end{array}$ & $\begin{array}{l}\text { O lugar como a experiência vivida dos homens com o território e } \\
\text { com as paisagens. } \\
\text { O imaginário e as representações da vida cotidiana: o } \\
\text { significado das coisas e dos lugares unindo e separando } \\
\text { pessoas. } \\
\text { O lugar como espaço vivido mediato e imediato dos homens na } \\
\text { interação com o mundo. } \\
\text { O mundo como uma pluralidade de lugares interagindo entre si. } \\
\text { A cidadania como a consciência de pertencer e interagir e } \\
\text { sentir-se integrado com pessoas e lugares. } \\
\text {. O drama do imigrante na ruptura com o lugar de origem tanto do } \\
\text { campo, como da cidade. } \\
\text {. A segregação socioeconômica e cultural como fator de exclusão } \\
\text { social e estímulo à criminalidade nas cidades. }\end{array}$ \\
\hline \multirow[t]{2}{*}{$\begin{array}{l}\text { O estudo da } \\
\text { natureza } \\
\text { e sua } \\
\text { importância } \\
\text { para o homem }\end{array}$} & $\begin{array}{l}\text { Os fenômenos } \\
\text { naturais, sua } \\
\text { regularidade e } \\
\text { possibilidade de } \\
\text { previsão pelo } \\
\text { homem }\end{array}$ & $\begin{array}{l}\text { Planeta Terra: a nave em que viajamos. } \\
\text { Como o relevo se forma: os diferentes tipos do relevo. } \\
\text { Litosfera e movimentos tectônicos: existem terremotos no } \\
\text { Brasil? } \\
\text {. As formas de relevo, os solos e sua ocupação: urbana e rural. } \\
\text { Erosão e desertificação: morte dos solos. } \\
\text { As águas e o clima. } \\
\text { Águas e terras no Brasil. } \\
\text {. Circulação atmosférica e estações do ano. } \\
\text { Clima do Brasil: como os diferentes tipos de clima afetam as } \\
\text { diferentes regiões. } \\
\text { O clima no cotidiano das pessoas. } \\
\text { As cidades e as alterações climáticas. } \\
\text { As florestas e sua interação com o clima. } \\
\text { Previsão do tempo e clima. } \\
\text { Como conhecer a vegetação brasileira: a megadiversidade do } \\
\text { mundo tropical. } \\
\text { Florestas tropicais: como funcionam essas centrais energéticas. } \\
\text { Cerrados e interações com os solos e o relevo. } \\
\text { Estudando e compreendendo as caatingas. } \\
\text { Saindo do mundo tropical para entender o pampa. } \\
\text { Pinheiros do Brasil: as florestas de araucária. }\end{array}$ \\
\hline & $\begin{array}{l}\text { A natureza e as } \\
\text { questões } \\
\text { socioambientais }\end{array}$ & $\begin{array}{l}\text { A floresta tropical vai acabar? } \\
\text { As reservas extrativistas e o desenvolvimento sustentável. } \\
\text { O lixo nas cidades: do consumismo à poluição. } \\
\text { Poluição ambiental e modo de vida urbano. } \\
\text {. Poluição ambiental e modo de produzir no campo. } \\
\text { Industrialização, degradação do ambiente e modo de vida. } \\
\text {. Problemas ambientais que atingem todo o planeta (o efeito } \\
\text { estufa, a destruição da camada de ozônio e a chuva ácida). } \\
\text {. Plantar sem degradar: outras formas de produzir no campo. } \\
\text {. Modo de vida urbano e qualidade de vida. } \\
\text {. Áreas protegidas e espaços livres urbanos. }\end{array}$ \\
\hline
\end{tabular}




\begin{tabular}{|c|c|c|}
\hline & & $\begin{array}{l}\text { O turismo e a degradação do ambiente. } \\
\text { Conservação ambiental, cidadania e pluralidade cultural. } \\
\text { Conhecer a natureza e respeitar suas leis próprias: produzir } \\
\text { sem degradar. } \\
\text {. Pluralidade cultural e etnociência. } \\
\text {. Urbanização e degradação ambiental. }\end{array}$ \\
\hline \multirow[t]{4}{*}{$\begin{array}{l}\text { O campo e a } \\
\text { cidade como } \\
\text { formações } \\
\text { socioespaciais }\end{array}$} & $\begin{array}{l}\text { O espaço como } \\
\text { acumulação de } \\
\text { tempos } \\
\text { desiguais }\end{array}$ & 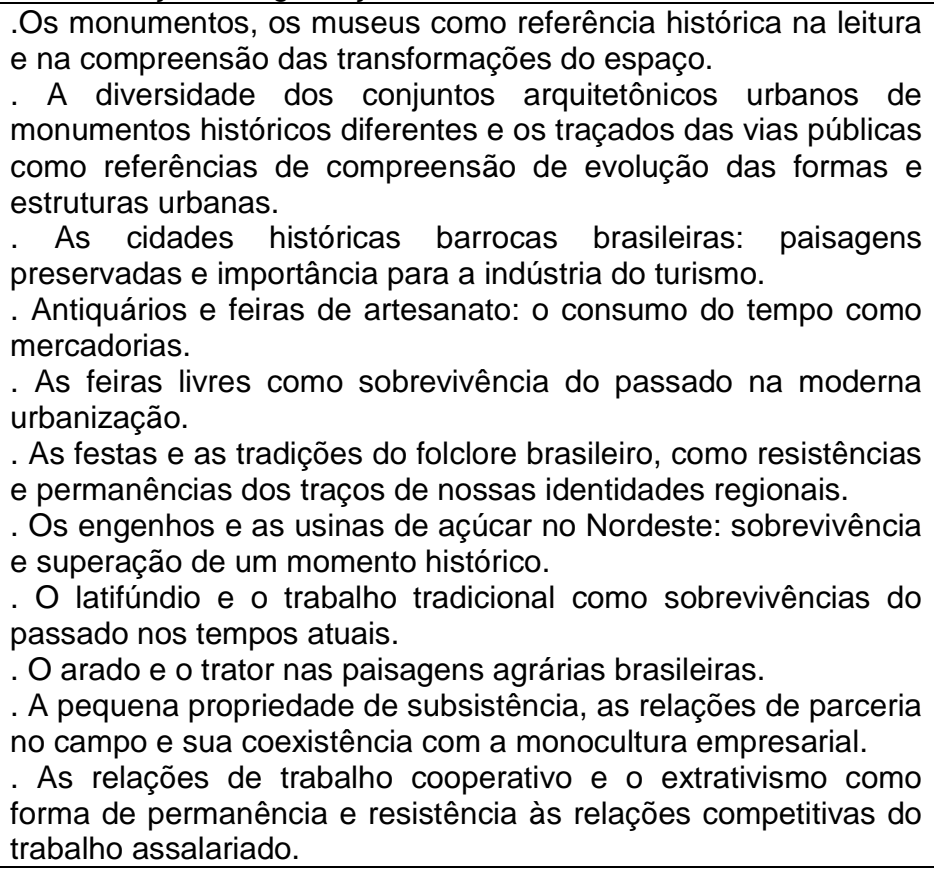 \\
\hline & $\begin{array}{l}\text { A } \\
\text { modernização } \\
\text { capitalista e a } \\
\text { redefinição nas } \\
\text { relações entre o } \\
\text { campo e a } \\
\text { cidade }\end{array}$ & $\begin{array}{l}\text { A entrada das multinacionais no campo e seu papel nas } \\
\text { exportações brasileiras. } \\
\text {. Os problemas enfrentados atualmente pelos pequenos e } \\
\text { médios produtores do campo. } \\
\text {. O abastecimento das cidades e o papel do pequeno e médio } \\
\text { produtor do campo. } \\
\text {. A mecanização, a automação e a concentração de propriedade } \\
\text { e o problema dos sem-terra. } \\
\text {. Os sem-teto nas metrópoles e suas relações com processo de } \\
\text { modernização capitalista. } \\
\text { As metrópoles como centro de gestão das inovações } \\
\text { tecnológicas e gestão do capital e suas repercussões no campo. } \\
\text { Modernização e desemprego no campo e na cidade. } \\
\text {. A importância da reforma agrária como solução para os grandes } \\
\text { problemas sociais do campo e da cidade no Brasil. }\end{array}$ \\
\hline & $\begin{array}{l}\text { O papel do } \\
\text { Estado e das } \\
\text { classes sociais } \\
\text { e a sociedade } \\
\text { urbanoindustrial } \\
\text { brasileira }\end{array}$ & $\begin{array}{l}\text { A transição da hegemonia das oligarquias agrárias para a } \\
\text { burguesia industrial-financeira na organização política do Estado } \\
\text { brasileiro. } \\
\text { O deslocamento do polo do poder econômico da região } \\
\text { Nordeste para o Sudeste brasileiro. } \\
\text { O crescimento do proletariado no campo e na cidade e sua } \\
\text { presença na organização política do Estado brasileiro. } \\
\text { O milagre brasileiro e a posição do Brasil no conjunto das } \\
\text { relações políticas internacionais. } \\
\text {. As políticas neoliberais, o Estado brasileiro e as atuais } \\
\text { perspectivas de desenvolvimento para a sociedade brasileira. }\end{array}$ \\
\hline & $\begin{array}{l}\text { A cultura e o } \\
\text { consumo: uma } \\
\text { nova interação } \\
\text { do campo e da } \\
\text { cidade }\end{array}$ & $\begin{array}{l}\text { Os hábitos de consumo das pessoas do campo antes e após o } \\
\text { surto de industrialização dos anos } 50 \text {. } \\
\text {. A influência das formas de viver na cidade e no campo e a } \\
\text { expansão dos meios de comunicação e dos transportes. } \\
\text {. A sociabilidade entre as pessoas e os grupos sociais no campo } \\
\text { e na cidade. } \\
\text {. A mídia, o imaginário social e os movimentos migratórios do } \\
\text { campo para a cidade. } \\
\text {. As relações de troca monetária do homem no campo e as }\end{array}$ \\
\hline
\end{tabular}




\begin{tabular}{|c|c|c|}
\hline & & possibilidades de sua inserção no mundo urbano. \\
\hline \multirow[t]{2}{*}{$\begin{array}{l}\text { A cartografia } \\
\text { como } \\
\text { instrumento } \\
\text { na } \\
\text { aproximação } \\
\text { dos lugares e } \\
\text { do mundo }\end{array}$} & $\begin{array}{l}\text { Da } \\
\text { alfabetização } \\
\text { cartográfica à } \\
\text { leitura crítica e } \\
\text { ao } \\
\text { mapeamento } \\
\text { consciente }\end{array}$ & $\begin{array}{l}\text { Os conceitos de escala e suas diferenciações e importância para } \\
\text { as análises espaciais nos estudos de Geografia. } \\
\text {. Os pontos cardeais, utilidades práticas e referenciais nos } \\
\text { mapas. } \\
\text { - Orientação e medição cartográfica. } \\
\text {. Coordenadas geográficas. } \\
\text {. Uso de cartas para orientar trajetos no cotidiano. } \\
\text { - Localização e representação em mapas, maquetes e croquis. } \\
\text {. Localização e representação das posições na sala de aula, em } \\
\text { casa, no bairro e na cidade. } \\
\text {. Leitura, criação e organização de legendas. } \\
\text {. Análise de mapas temáticos das cidades, dos estados e do } \\
\text { Brasil. } \\
\text {. Estudo com base em plantas e cartas temáticas simples. } \\
\text {. A utilização de diferentes tipos de mapas: mapas de itinerário, } \\
\text { turísticos, climáticos, relevo, vegetação, etc. } \\
\text {. Confecção pelos alunos de croquis cartográficos elementares } \\
\text { para analisar informações e estabelecer correlação entre fatos. }\end{array}$ \\
\hline & $\begin{array}{l}\text { Os mapas } \\
\text { como } \\
\text { possibilidade de } \\
\text { compreensão e } \\
\text { estudos } \\
\text { comparativos } \\
\text { das diferentes } \\
\text { paisagens e } \\
\text { lugares }\end{array}$ & $\begin{array}{l}\text { Os pontos cardeais e sua importância como sistema de } \\
\text { referência nos estudos da paisagem, lugares e territórios. } \\
\text {. A cartografia e os sistemas de orientação espacial. } \\
\text { Cartas de relevo de diferentes paisagens e medidas } \\
\text { cartográficas (altitude e distância). } \\
\text {. Análises de cartas temáticas (densidade populacional, relevo, } \\
\text { vegetação, etc.). } \\
\text {. Estudo das cartas das formas de relevo e de utilização do solo. } \\
\text { Estudo das cartas de tipos de clima, massas de ar, formações } \\
\text { vegetais, distribuição populacional, centros industriais, urbanos e } \\
\text { outros. } \\
\text { - Mapear e desenhar croqui correlacionando cartas simples. } \\
\text { Leitura de cartas sintéticas. } \\
\text { - Leitura e mapeamento de cartas regionais com os símbolos } \\
\text { precisos. } \\
\text {. Elaboração de croquis com legendas fornecidas pelo professor. } \\
\text {. Análise de cartas temáticas que apresentam vários fenômenos. } \\
\text { Identificar, compilar e produzir mapas intermediários dos } \\
\text { elementos fundamentais a partir de uma carta complexa. }\end{array}$ \\
\hline
\end{tabular}

Fonte: Brasil (1998: 86). 
ANEXO C: Resumo do PCN do 4 Ciclo

\begin{tabular}{|c|c|c|}
\hline Eixo & Tema & Item \\
\hline \multirow[t]{2}{*}{$\begin{array}{l}\text { A evolução das } \\
\text { tecnologias e } \\
\text { as } \\
\text { novas } \\
\text { territorialidades } \\
\text { em } \\
\text { redes }\end{array}$} & $\begin{array}{l}\text { A velocidade e a } \\
\text { eficiência dos } \\
\text { transportes e da } \\
\text { comunicação } \\
\text { como o } \\
\text { novo paradigma } \\
\text { da } \\
\text { globalização }\end{array}$ & $\begin{array}{l}\text { A evolução das técnicas no transporte ferroviário e a } \\
\text { integração dos mercados. } \\
\text { A evolução das técnicas na navegação e a integração dos } \\
\text { mercados. } \\
\text {. As tecnologias computacionais e os avanços na navegação } \\
\text { aérea. } \\
\text { As tecnologias computacionais e a expansão das } \\
\text { multinacionais. } \\
\text {. As políticas de transportes metropolitanos: os transportes } \\
\text { coletivos, o metrô e o automóvel. } \\
\text {. A Internet, a comunicação instantânea e simultânea e a } \\
\text { aproximação dos lugares. }\end{array}$ \\
\hline & $\begin{array}{l}\text { A globalização e } \\
\text { as } \\
\text { novas hierarquias } \\
\text { urbanas }\end{array}$ & $\begin{array}{l}\text { Os polos técnico-científicos informacionais e os novos centros } \\
\text { de decisões. } \\
\text {. A nova divisão internacional do trabalho e as redes de cidades } \\
\text { mundiais. } \\
\text { A urbanização no período técnico-científico informacional, a } \\
\text { automação e o problema do desemprego. } \\
\text { industriais em terciárias. }\end{array}$ \\
\hline \multirow[t]{3}{*}{$\begin{array}{l}\text { Um só mundo } \\
\text { e } \\
\text { muitos } \\
\text { cenários } \\
\text { geográficos }\end{array}$} & $\begin{array}{l}\text { Estado, povos e } \\
\text { nações } \\
\text { redesenhando } \\
\text { suas } \\
\text { fronteiras }\end{array}$ & $\begin{array}{l}\text { Mobilização das fronteiras e conflitos internacionais. } \\
\text { Os espaços das minorias nacionais, étnicas e culturais. } \\
\text {. As mudanças atuais nas relações políticas internacionais e a } \\
\text { atual ordem mundial: a busca de novas hegemonias. } \\
\text { O mercado desenhando novas fronteiras: a formação dos } \\
\text { blocos econômicos regionais. } \\
\text { Mapeamento dos conflitos contemporâneos no mundo. } \\
\text {. Os países da África e América Latina no contexto da nova } \\
\text { ordem mundial. } \\
\text {. As organizações políticas internacionais e os novos conceitos } \\
\text { de soberania. } \\
\text { * Indicadores econômicos e sociais da riqueza e do bem-estar e } \\
\text { do desenvolvimento humano. } \\
\text { * Pobreza e exclusão social nos países desenvolvidos e } \\
\text { subdesenvolvidos. } \\
\text { * Novas localizações para as atividades empresariais nas } \\
\text { regiões, flexibilização nas escolhas e competição entre os } \\
\text { lugares. } \\
\text { * Mudanças nas relações de troca no mercado mundial e os } \\
\text { novos países industrializados. }\end{array}$ \\
\hline & $\begin{array}{l}\text { Uma região em } \\
\text { construção: o } \\
\text { Mercosul }\end{array}$ & $\begin{array}{l}\text { A identidade histórica da colonização iberoamericana e a } \\
\text { dependência econômica dos seus países com a Europa. } \\
\text {. Os interesses econômicos da política dos Estados na } \\
\text { construção do Mercosul e o papel das multinacionais. } \\
\text { A expansão do turismo entre os países do Mercosul. } \\
\text { A questão da integração dos espaços periféricos no interior } \\
\text { dessa região: a exemplo da Patagônia, Chaco, Nordeste, } \\
\text { Amazônia. } \\
\text { A questão da integração latino-americana com o Mercosul. } \\
\text { A integração territorial e os transportes: estágios e } \\
\text { perspectivas. } \\
\text { O patrimônio cultural como fator de integração latino- } \\
\text { americana. } \\
\text { A questão indígena no Mercosul. } \\
\text { A questão ambiental no Mercosul. }\end{array}$ \\
\hline & $\begin{array}{l}\text { Paisagens e } \\
\text { diversidade } \\
\text { territorial no Brasil }\end{array}$ & $\begin{array}{l}\text { Formas de produção e relações de trabalho no } \\
\text { desenvolvimento desigual do território brasileiro. } \\
\text {. Pluralidade cultural e paisagens brasileiras: a exemplo da } \\
\text { cana-de-açúcar, da mineração do ouro, dos quilombos, áreas } \\
\text { indígenas, vilas caiçaras etc. } \\
\text { As expressões culturais de origem europeia, africana, } \\
\text { indígena, asiática e outras nas paisagens brasileiras. }\end{array}$ \\
\hline
\end{tabular}




\begin{tabular}{|c|c|c|}
\hline & & $\begin{array}{l}\text { Condicionantes naturais na modelagem das paisagens } \\
\text { brasileiras: os processos interativos e a fisionomia das } \\
\text { paisagens. } \\
\text { Mobilidade da população e reprodução das desigualdades } \\
\text { socioespaciais nas cidades e no campo. }\end{array}$ \\
\hline \multirow[t]{3}{*}{$\begin{array}{l}\text { Modernização, } \\
\text { modos de vida } \\
\text { e a } \\
\text { problemática } \\
\text { ambiental }\end{array}$} & $\begin{array}{l}\text { O processo } \\
\text { técnico- } \\
\text { econômico, a } \\
\text { política e os } \\
\text { problemas } \\
\text { socioambientais }\end{array}$ & $\begin{array}{l}\text { Progressos técnico-científicos mediando as relações } \\
\text { sociedade/natureza. } \\
\text {. As revoluções técnico-científicas, o consumo de energia e } \\
\text { outros recursos naturais e seus impactos no ambiente. } \\
\text {. As indústrias, os transportes e o ambiente nos tempos da } \\
\text { máquina a vapor. } \\
\text { Os motores a explosão, a intensificação da revolução } \\
\text { tecnológica, o uso dos recursos naturais e a degradação } \\
\text { ambiental. } \\
\text { - Recursos naturais, esgotabilidade e reversibilidade: usar e } \\
\text { recuperar. }\end{array}$ \\
\hline & $\begin{array}{l}\text { Alimentar o } \\
\text { mundo: } \\
\text { os dilemas } \\
\text { socioambientais } \\
\text { para a segurança } \\
\text { alimentar }\end{array}$ & $\begin{array}{l}\text { Revolução verde: o que foi e o que representa para o } \\
\text { ambiente. } \\
\text {. Poluição no campo com uso de agrotóxicos. } \\
\text {. Conservação e degradação dos solos (erosão, perda de } \\
\text { fertilidade, desertificação, salinização, irrigação). } \\
\text {. Sistemas agrícolas (agricultura comercial, monocultura, } \\
\text { policultura, agricultura ecológica, agriculturas alternativas, } \\
\text { biotecnologia). } \\
\text {. Biodiversidade e agricultura. } \\
\text {. Extrativismo e as florestas tropicais. } \\
\text { Agricultura tecnificada, insumos agrícolas e poluição das } \\
\text { águas de superfície. } \\
\text {. Insumos agrícolas e destruição da fauna. } \\
\text { - Movimentos sociais no campo e a questão ambiental. } \\
\text { Sistemas agroflorestais. } \\
\text { Sistemas agrossilvopastoris. } \\
\text { Florestas plantadas (fontes de madeira, celulose e papel) e a } \\
\text { sustentabilidade ambiental. } \\
\text {. Recuperação de florestas e a captura de monóxido de } \\
\text { carbono. }\end{array}$ \\
\hline & $\begin{array}{l}\text { Ambiente urbano, } \\
\text { indústria e modo } \\
\text { de } \\
\text { vida }\end{array}$ & 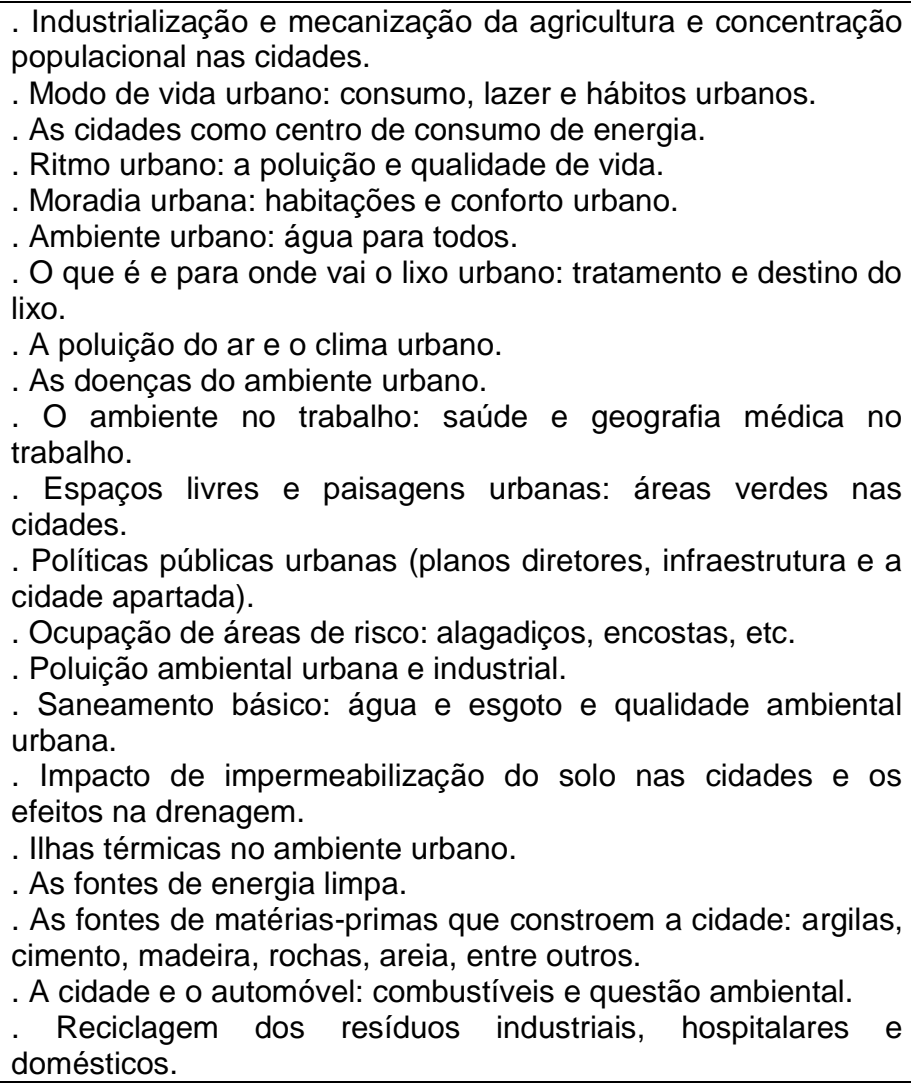 \\
\hline
\end{tabular}




\begin{tabular}{|c|c|}
\hline & $\begin{array}{l}\text {. Indústria petroquímica e ambiente urbano (os casos: Cubatão, } \\
\text { Camaçari, Triunfo e Duque de Caxias). }\end{array}$ \\
\hline $\begin{array}{l}\text { O Brasil diante } \\
\text { das } \\
\text { questões } \\
\text { ambientais }\end{array}$ & $\begin{array}{l}\text {. Desmatamentos e queimadas como práticas econômicas. } \\
\text { Garimpo: prática perversa de economia periférica: } \\
\text { trabalhadores excluídos e degradação ambiental. } \\
\text {. Mineração: apropriação dos recursos ambientais e } \\
\text { degradação da natureza. } \\
\text {. Modelos alternativos de utilização das florestas tropicais. } \\
\text {. Modo de vida e conservação ambiental. } \\
\text { Sistema de Áreas Protegidas. } \\
\text { - Planejamento ambiental e políticas públicas (Planafloro, } \\
\text { Gerenciamento Costeiro, Plano de Conservação do Pantanal, } \\
\text { Programa de Proteção de Florestas. PPG7, Zoneamento } \\
\text { Ecológico-Econômico). } \\
\text {. Impactos das grandes barragens e açudes. } \\
\text { - Conservação x preservação e conflitos socioambientais. } \\
\text {. Conservação e cidadania. } \\
\text {. Indústria do turismo e degradação ambiental. } \\
\text {. Ecoturismo. } \\
\text {. Urbanização e questão ambiental. } \\
\text {. Pluralidade cultural e conservação da natureza. } \\
\text {. Degradação do cerrado x monocultura e pecuária extensiva } \\
\text { melhorada. } \\
\text {. Os grandes domínios de vegetação e os diferentes usos. } \\
\text {. Reflorestamento e conservação da mata de araucária. } \\
\text {. A Homogeneização florestal com silvicultura no Sul e Sudeste } \\
\text { do Brasil. } \\
\text {. Práticas agrícolas e fronteiras agropecuárias na Amazônia. } \\
\text {. Desmatamento e exploração do carvão vegetal nas caatingas } \\
\text { e cerrados. } \\
\text {. Legislação ambiental brasileira. }\end{array}$ \\
\hline $\begin{array}{l}\text { Ambientalismo: } \\
\text { pensar e agir }\end{array}$ & $\begin{array}{l}\text {. Agenda 21: Relações nacionais e internacionais na questão } \\
\text { ambiental (PPG7- Convenção da Biodiversidade, Convenção do } \\
\text { Desenvolvimento Sustentável, Convenção de Kyoto, etc.). } \\
\text {. Políticas e estratégias internacionais para o desenvolvimento } \\
\text { sustentável (de Estocolmo a Rio). } \\
\text {. Movimento ambientalista e pluralidade de ideias. } \\
\text {. Movimento ambientalista e movimento de luta pela terra. } \\
\text {. Pluralidade cultural brasileira e ambientalismo. } \\
\text {. Organizações não governamentais no Brasil: objetivos e } \\
\text { campos de atuação. } \\
\text {. Soberania nacional e a legislação ambiental brasileira. }\end{array}$ \\
\hline
\end{tabular}

Fonte: Brasil (1998: 124-129). 


\section{ANEXO D: Sugestão de organização de eixos temáticos em Geografia para o Ensino Médio}

\begin{tabular}{|c|c|}
\hline \multicolumn{2}{|l|}{ Eixo temáticos } \\
\hline \multicolumn{2}{|l|}{ A dinâmica do espaço geográfico } \\
\hline Temas & Subtemas \\
\hline 1. A fisionomia da superfície terrestre & $\begin{array}{l}\text { - Tempo geológico; tempo histórico. } \\
\text { - Dinâmica da litosfera. O relevo. } \\
\text { - Dinâmica da superfície hídrica. } \\
\text { - Os seres vivos e sua dinâmica. }\end{array}$ \\
\hline $\begin{array}{l}\text { 2. As conquistas tecnológicas e a } \\
\text { alteração do equilíbrio natural }\end{array}$ & $\begin{array}{l}\text { - O ser humano, ser natural. } \\
\text { - A cultura humana e suas conquistas. } \\
\text { - Técnicas; tecnologia. Alteração da paisagem. } \\
\text { - O ser humano e a utilização dos recursos naturais. }\end{array}$ \\
\hline $\begin{array}{l}\text { 3. Ações em defesa do substrato } \\
\text { natural e da qualidade de vida }\end{array}$ & $\begin{array}{l}\text { - Os problemas ambientais e sua origem. } \\
\text { - Grandes catástrofes ambientais e suas causas. } \\
\text { - Consciência ambiental. Movimentos e mobilização. } \\
\text { - Conferências internacionais. Resistência política. } \\
\text { - Os caminhos do problema ambiental. }\end{array}$ \\
\hline $\begin{array}{l}\text { 4. Informações e recursos: } \\
\text { representação dos fatos relativos à } \\
\text { dinâmica terrestre }\end{array}$ & $\begin{array}{l}\text { - Recursos disponíveis para o registro de problemas } \\
\text { ambientais. } \\
\text { - Teledetecção: satélites a serviço da questão } \\
\text { ambiental. } \\
\text { - A produção cartográfica sobre a questão ambiental. }\end{array}$ \\
\hline \multicolumn{2}{|c|}{ O mundo em transformação: as questões econômicas e os problemas geopolíticos } \\
\hline Temas & Subtemas \\
\hline 1. Um mundo que se abre & $\begin{array}{l}\text { - Redes, técnicas, fluxos. } \\
\text { - O fim da Guerra Fria e a expansão do capitalismo. } \\
\text { - A ONU como poder decisório em questão. } \\
\text { - A moderna diplomacia. }\end{array}$ \\
\hline 2. Um mundo que se fecha & $\begin{array}{l}\text { - Desenvolvimento e subdesenvolvimento: distâncias } \\
\text { que aumentam. } \\
\text { - Blocos econômicos. Interesses políticos. } \\
\text { - Nacionalismos e separatismos. } \\
\text { - A América em busca de novos caminhos. }\end{array}$ \\
\hline 3. Tensões, conflitos, guerras & $\begin{array}{l}\text { - Documentando o mundo político. Os mapas. Os } \\
\text { gráficos. } \\
\text { - Índices de desempenho e sua utilização. } \\
\text {-A representação do local e do global. } \\
\text { - O mapa como instrumento ideológico. }\end{array}$ \\
\hline \multicolumn{2}{|c|}{ O homem criador de paisagem/modificador do espaço } \\
\hline Temas & Subtemas \\
\hline $\begin{array}{l}\text { 1. O espaço geográfico } \\
\text { produzido/apropriado }\end{array}$ & $\begin{array}{l}\text { - O espaço das técnicas: sistemas de objetos; } \\
\text { sistemas de ações. } \\
\text { - Fluxos, estradas, redes de comunicação. } \\
\text { - A produção e o uso da energia. } \\
\text { - Divisão internacional do trabalho e da produção. }\end{array}$ \\
\hline 2. A paisagem rural & $\begin{array}{l}\text { - O meio rural tradicional. } \\
\text { - O campo e a invasão do capital industrial. } \\
\text { - Produção agrícola e tecnologia. } \\
\text { - Produção agrícola e persistência da fome. }\end{array}$ \\
\hline 3. A paisagem urbana & $\begin{array}{l}\text { - A cidade como espaço de transformação industrial. } \\
\text { - A cidade prestadora de serviços. } \\
\text { - Metrópoles. Metropolização. } \\
\text { - Problemas urbanos. } \\
\text { - Serviços básicos na cidade. }\end{array}$ \\
\hline $\begin{array}{l}\text { 4. A população mundial: estrutura, } \\
\text { dinâmica e problemas }\end{array}$ & $\begin{array}{l}- \text { Ricos e pobres. A concentração das riquezas. A } \\
\text { fome e as doenças. }\end{array}$ \\
\hline
\end{tabular}




\begin{tabular}{|c|c|}
\hline & $\begin{array}{l}\text { - Etnias, religiões, culturas. } \\
\text { - Migrações. A população em movimento. } \\
\text { - A população e o acesso aos bens produzidos. }\end{array}$ \\
\hline \multicolumn{2}{|c|}{ O território brasileiro: um espaço globalizado } \\
\hline Temas & Subtemas \\
\hline 1. Nacionalidade e identidade cultural & $\begin{array}{l}\text { - População brasileira e sua identidade. } \\
\text { - Crescimento populacional e dinâmica: migrações. } \\
\text { - Urbanização. Periferização. } \\
\text { - Transformações culturais da população brasileira. } \\
\text { - As minorias étnicas e sua integração na sociedade } \\
\text { brasileira. }\end{array}$ \\
\hline 2. A ocupação produtiva do território & $\begin{array}{l}\text { - O campo brasileiro e suas transformações. } \\
\text { - Os caminhos da industrialização brasileira. } \\
\text { - O delineamento e a estrutura da questão energética } \\
\text { no Brasil. } \\
\text { - As cidades brasileiras e a prestação de serviços. }\end{array}$ \\
\hline $\begin{array}{l}\text { 3. O problema das comunicações num } \\
\text { território muito extenso }\end{array}$ & $\begin{array}{l}\text { - O modelo brasileiro de rede de transportes. } \\
\text { - O transporte nas áreas urbanas e metropolitanas. } \\
\text { - A circulação de valores e do pensamento. } \\
\text { O Brasil no contexto internacional } \\
\text { - Transportes, comunicações e integração nacional. }\end{array}$ \\
\hline 4. A questão ambiental no Brasil & $\begin{array}{l}\text { - Os interesses econômicos e a degradação } \\
\text { ambiental. } \\
\text { - A degradação ambiental nas grandes cidades. } \\
\text { - Dependência econômica e degradação ambiental. } \\
\text { - O Brasil e os acordos ambientais internacionais. }\end{array}$ \\
\hline
\end{tabular}

Fonte: BRASIL (2000: 66, 67 e 68). 
ANEXO E: CBC - Eixos temáticos

- Eixo temático I: Tema 1: Cotidiano de convivência, trabalho e lazer

Temas complementares:

- Mudanças nas relações sociais do trabalho no campo e nas cidades

mineiras.

- A qualidade de vida e o crescimento populacional.

- Os bastidores da vida urbana: os grupos sociais segregados criando novas terrritorialidades.

- O poder das redes ilegais no cotidiano de países.

\begin{tabular}{|c|c|}
\hline $\begin{array}{l}\text { TÓPICOS / } \\
\text { HABILIDADES }\end{array}$ & DETALHAMENTO DAS HABILIDADES \\
\hline \multirow[t]{2}{*}{$\begin{array}{l}\text { 1. Território e } \\
\text { territorialidade }\end{array}$} & $\begin{array}{l}\text { 1.1. Reconhecer em imagens/fotos de tempos diferentes as mudanças ocorridas na } \\
\text { produção do espaço urbano e rural, sabendo explicar a sua temporalidade. }\end{array}$ \\
\hline & $\begin{array}{l}\text { 1.2. Compreender no cotidiano as noções de território e territorialidade, aplicando-as nas } \\
\text { situações que produzem a vida na cidade e no campo. }\end{array}$ \\
\hline \multirow[t]{2}{*}{$\begin{array}{l}\text { 2. Paisagens do } \\
\text { cotidiano }\end{array}$} & $\begin{array}{l}\text { 2.1. Interpretar as paisagens urbanas e rurais em suas oportunidades de trabalho e lazer } \\
\text { valendo-se de imagens/fotos de tempos diferentes. }\end{array}$ \\
\hline & $\begin{array}{l}\text { 2.2. Reconhecer nos cotidianos da paisagem urbana e rural o que a cultura e o trabalho } \\
\text { conferiram como identidade de um lugar }\end{array}$ \\
\hline \multirow[t]{2}{*}{$\begin{array}{l}\text { 3. Cidadania e } \\
\text { direitos } \\
\text { sociais }\end{array}$} & $\begin{array}{l}\text { 3.1. Reconhecer na paisagem urbana e rural, a cultura, o trabalho e o lazer como identidade } \\
\text { de } \\
\text { um lugar e direitos à cidadania. }\end{array}$ \\
\hline & $\begin{array}{l}\text { 3.2. Ler e interpretar em mapas, dados e tabelas os avanços dos direitos sociais no Brasil e } \\
\text { no mundo. }\end{array}$ \\
\hline \multirow[t]{2}{*}{ 4. Lazer } & $\begin{array}{l}\text { 4.1. Explicar o lazer na sociedade atual tendo como referência a mundialização de } \\
\text { fenômenos econômicos, tecnológicos e culturais. }\end{array}$ \\
\hline & $\begin{array}{l}\text { 4.2. Identificar no cotidiano urbano os elementos que representam a espacialidade e } \\
\text { territorialidade do lazer. }\end{array}$ \\
\hline \multirow[t]{3}{*}{$\begin{array}{l}\text { 5. Segregação } \\
\text { espacial }\end{array}$} & $\begin{array}{l}\text { 5.1. Identificar as questões que envolvem a segregação espacial em imagens, textos e na } \\
\text { observação da vida cotidiana. }\end{array}$ \\
\hline & $\begin{array}{l}\text { 5.2. Explicar os tipos de relações sociais existentes no território relacionando-os com os } \\
\text { lugares, suas estratégias de segregação e exclusão das populações marginalizadas. }\end{array}$ \\
\hline & $\begin{array}{l}\text { 5.3. Reconhecer a cidade na sua territorialidade de bandos, gangues, identificando as } \\
\text { demarcações no seu espaço de vivência e relacionando-os com a singularidade ou } \\
\text { generalidade de outros cotidianos. }\end{array}$ \\
\hline \multirow[t]{2}{*}{$\begin{array}{l}\text { 6. Redes e } \\
\text { circulação }\end{array}$} & $\begin{array}{l}\text { 6.1. Reconhecer as redes que possibilitam a circulação de informações, mercadorias e } \\
\text { pessoas. }\end{array}$ \\
\hline & $\begin{array}{l}\text { 6.2. Interpretar gráficos e tabelas que expressem o movimento e a circulação das pessoas, } \\
\text { produtos e ideias no cotidiano urbano. }\end{array}$ \\
\hline \multirow[t]{3}{*}{$\begin{array}{l}\text { I. Região e } \\
\text { regionalização }\end{array}$} & $\begin{array}{l}\text { Ler mapas temáticos sabendo extrair deles elementos de comparação e análise dos } \\
\text { aspectos evidenciados no tema estudado. }\end{array}$ \\
\hline & $\begin{array}{l}\text { - Compreender a relação entre as características econômicas das sociedades e a produção } \\
\text { do espaço. }\end{array}$ \\
\hline & $\begin{array}{l}\text { - Comparar o Índice de Desenvolvimento Humano (IHD) local e/ ou regional com a } \\
\text { capacidade de uso e apropriação do espaço. }\end{array}$ \\
\hline $\begin{array}{l}\text { II. Espaços de } \\
\text { convivência, de } \\
\text { trabalho, de }\end{array}$ & $\begin{array}{l}\text { - Interpretar gráficos, fotos e tabelas que expressem fenômenos urbanos da urbanidade e do } \\
\text { entretenimento. }\end{array}$ \\
\hline
\end{tabular}




\begin{tabular}{|c|c|}
\hline \multirow[t]{2}{*}{$\begin{array}{l}\text { lazer: } \\
\text { cidade e } \\
\text { urbanidade }\end{array}$} & $\begin{array}{l}\text { - Identificar, conhecer e avaliar os laços de identidade da cidade com o cidadão, as } \\
\text { manifestações populares e o trabalho, assim como a falta de trabalho e a repressão às } \\
\text { manifestações, em textos e fotos. }\end{array}$ \\
\hline & $\begin{array}{l}\text { - Comparar as marcas da mudança na produção do espaço urbano através da análise de } \\
\text { fotos de ruas, avenidas, praças que revelam a urbanidade. }\end{array}$ \\
\hline \multirow[t]{3}{*}{$\begin{array}{l}\text { III. Patrimônio e } \\
\text { ambiente }\end{array}$} & $\begin{array}{l}\text { - Identificar no espaço urbano as construções patrimoniais, explicando seu valor cultural } \\
\text { associado à preservação. }\end{array}$ \\
\hline & $\begin{array}{l}\text {-Analisar os impactos ambientais produzidos pela relação sociedade e natureza nos } \\
\text { cotidianos urbanos. }\end{array}$ \\
\hline & $\begin{array}{l}\text { - Analisar os impactos advindos das transformações no uso do patrimônio, propondo } \\
\text { soluções para os problemas ambientais urbanos. }\end{array}$ \\
\hline \multirow[t]{2}{*}{$\begin{array}{l}\text { IV. } \\
\text { Espacialidade }\end{array}$} & $\begin{array}{l}\text { - Comparar fotos de ruas, avenidas e praças, identificando as permanências e mudanças } \\
\text { expressas na espacialidade. }\end{array}$ \\
\hline & $\begin{array}{l}\text { - Identificar os arranjos espaciais que se manifestam em cotidianos urbanos sabendo } \\
\text { categorizá-los e interpretá-los. }\end{array}$ \\
\hline
\end{tabular}

- Eixo temático II: Tema 2: Patrimônios ambientais do território brasileiro

Temas complementares:

- Os sistemas técnicos no cotidiano da sociedade de consumo.

- Identidades territoriais e preservação da memória de um povo: estudos de caso.

- Os sítios arqueológicos do território mineiro e sua territorialização como atratividade turística.

\section{A Sociodiversidade das Paisagens e suas Manifestações Espaço- Culturais}

\begin{tabular}{|c|c|c|c|c|c|}
\hline \multirow{2}{*}{$\begin{array}{l}\text { TÓPICOS / } \\
\text { HABILIDADES }\end{array}$} & \multirow[t]{2}{*}{ DETALHAMENTO DAS HABILIDADES } & & & & \\
\hline & & $6^{\circ}$ & 7 & 8 & $9^{\circ}$ \\
\hline \multirow[t]{2}{*}{ 7. Turismo } & $\begin{array}{l}\text { 7.1. Explicar a relevância de uma cultura de turismo e de } \\
\text { lazer para a preservação da natureza e do patrimônio } \\
\text { cultural dos lugares e regiões turísticas. }\end{array}$ & 8 & & 3 & \\
\hline & $\begin{array}{l}\text { 7.2. Distinguir parâmetros de turismo sustentável e } \\
\text { insustentável, explicando os impactos em nível } \\
\text { sociocultural, socioambiental e socioeconômico. }\end{array}$ & & 4 & 3 & \\
\hline \multirow[t]{2}{*}{$\begin{array}{l}\text { 8. Cultura e } \\
\text { natureza }\end{array}$} & $\begin{array}{l}\text { 8.1. Identificar e analisar a ação modeladora da cultura } \\
\text { sobre a natureza do planeta; }\end{array}$ & 6 & & & \\
\hline & $\begin{array}{llll}\text { 8.2. Reconhecer a dinâmica cultural } & \text { moldada } & \text { em } \\
\text { diferentes paisagens no Brasil e no mundo. } & & \end{array}$ & & 6 & & \\
\hline \multirow[t]{3}{*}{$\begin{array}{l}9 . \\
\text { Sociodiversidad } \\
\text { e }\end{array}$} & $\begin{array}{l}\text { 9.1. Compreender o conceito de sociodiversidade das } \\
\text { paisagens, identificando-o em sua espacialidade municipal } \\
\text { e regional. }\end{array}$ & & 6 & & \\
\hline & $\begin{array}{l}\text { 9.2. Identificar, analisar e avaliar o impacto das } \\
\text { transformações culturais nas sociedades tradicionais } \\
\text { provocadas pela mudança nos hábitos de consumo. }\end{array}$ & & 8 & & \\
\hline & $\begin{array}{l}\text { 9.3. Identificar em mapas, gráficos e fotos a população } \\
\text { brasileira e mundial, em seu crescimento, tendências e } \\
\text { distribuição. }\end{array}$ & & 6 & 4 & \\
\hline \multirow[t]{2}{*}{$\begin{array}{l}\text { 10. Cultura e } \\
\text { natureza }\end{array}$} & $\begin{array}{l}\text { 10.1. Identificar os elementos da natureza em seus } \\
\text { aspectos geológicos, geomorfológicos e hidrológicos e as } \\
\text { transformações culturais regionais. }\end{array}$ & 8 & & & \\
\hline & $\begin{array}{l}\text { 10.2. Reconhecer os aspectos principais dos diferentes } \\
\text { tipos de clima no mundo e no Brasil. }\end{array}$ & & & & \\
\hline \multirow[t]{2}{*}{$\begin{array}{l}\text { V. Território e } \\
\text { territorialidade }\end{array}$} & $\begin{array}{l}\text {-Identificar as fronteiras culturais do território brasileiro, } \\
\text { localizando-as no mapa. }\end{array}$ & & & & \\
\hline & $\begin{array}{l}\text {-Reconhecer a sociodiversidade da nação brasileira, sua } \\
\text { localização no território e suas formas de manifestação e } \\
\text { interação. }\end{array}$ & & & & \\
\hline
\end{tabular}




\begin{tabular}{|c|c|c|c|}
\hline & $\begin{array}{l}\text {-Mapear nas formas visíveis e concretas do território usado } \\
\text { os processos históricos construídos em diferentes tempos. }\end{array}$ & & \\
\hline \multirow[t]{3}{*}{$\begin{array}{l}\text { VI. Populações } \\
\text { tradicionais }\end{array}$} & $\begin{array}{l}\text {-Identificar e localizar no tempo e no espaço a distribuição } \\
\text { das populações tradicionais no território mineiro. }\end{array}$ & & \\
\hline & $\begin{array}{l}\text { - Relacionar o conteúdo legal dos direitos constitucionais } \\
\text { garantidos às populações tradicionais do território } \\
\text { brasileiro e seu cumprimento na prática existencial. }\end{array}$ & & \\
\hline & $\begin{array}{l}\text { - Analisar o modo de vida das populações tradicionais à } \\
\text { luz dos padrões de produção e consumo coerentes com } \\
\text { uma vida sustentável. }\end{array}$ & & \\
\hline \multirow[t]{2}{*}{$\begin{array}{l}\text { VII. Sistemas } \\
\text { técnicos }\end{array}$} & $\begin{array}{l}\text {-Identificar em imagens e linguagens diversas os } \\
\text { processos contemporâneos que resultam em profundas } \\
\text { mudanças no conteúdo técnico do espaço geográfico. }\end{array}$ & & \\
\hline & $\begin{array}{l}\text { - Reconhecer nos fenômenos espaciais contemporâneos } \\
\text { os sistemas técnicos que sinalizam para uma } \\
\text { transformação das vivências cotidianas da sociedade de } \\
\text { consumo. }\end{array}$ & & \\
\hline \multirow[t]{2}{*}{$\begin{array}{l}\text { VIII. Paisagem } \\
\text { cultural }\end{array}$} & $\begin{array}{l}\text {-Reconhecer, em dimensão } \text { multiescalar, diferentes } \\
\text { paisagens culturais distinguindo-as em sua singularidade. }\end{array}$ & & \\
\hline & $\begin{array}{l}\text {-Ler nas paisagens culturais brasileiras a espacialidade e } \\
\text { as múltiplas temporalidades socialmente construídas. }\end{array}$ & & \\
\hline \multirow[t]{3}{*}{$\begin{array}{l}\text { IX. Sítios } \\
\text { arqueológicos }\end{array}$} & $\begin{array}{l}\text {-Descrever as localizações relativas aos sítios } \\
\text { arqueológicos tombados pela Unesco no território } \\
\text { brasileiro avaliando sua relevância como patrimônio a ser } \\
\text { preservado. }\end{array}$ & & \\
\hline & $\begin{array}{l}\text {-Relacionar a importância de sítios arqueológicos com a } \\
\text { preservação da memória e da identidade territorial de um } \\
\text { povo. }\end{array}$ & & \\
\hline & $\begin{array}{l}\text {-Mapear os sítios arqueológicos do território mineiro e } \\
\text { avaliar sua territorialização como atratividade turística. }\end{array}$ & & \\
\hline \multirow[t]{2}{*}{$\begin{array}{l}\text { X. Patrimônio e } \\
\text { preservação }\end{array}$} & $\begin{array}{l}\text { - Explicar como o ecoturismo pode ajudar a preservar e } \\
\text { ampliar as áreas de proteção ambiental. }\end{array}$ & & \\
\hline & $\begin{array}{l}\text { - Descrever e localizar, no meio urbano e rural do estado } \\
\text { de MG, os aspectos relevantes do regionalismo mineiro } \\
\text { manifestado em sua sociodiversidade. }\end{array}$ & 4 & 4 \\
\hline
\end{tabular}

- Eixo temático III: Tema 3: Redesenhando o mapa do mundo: novas Regionalizações

Temas complementares:

- A globalização e a nova ordem mundial em diferentes momentos históricos e suas marcas nos

municípios mineiros.

- Conflitos étnicos redesenham o mapa do mundo.

- A sociedade do conhecimento, a inclusão digital e as redes técnicas de telecomunicação.

- A territorialidade das multinacionais com o avanço das Tecnologias da Informação e da

Comunicação.

- Identidades culturais regionais: paisagens que se expressam no movimento da globalização.

- O futuro dos países em crise e conflito de fronteiras.

- Minas Gerais no movimento da globalização: as redes técnicas.

Globalização e Regionalização no Mundo Contemporâneo 


\begin{tabular}{|c|c|}
\hline \multirow{2}{*}{$\begin{array}{l}11 . \\
\text { Regionalização } \\
\text { e } \\
\text { mercados }\end{array}$} & $\begin{array}{l}\text { 11.1. Compreender as formas de regionalizar o mundo, analisando os principais critérios de } \\
\text { classificações. }\end{array}$ \\
\hline & $\begin{array}{l}\text { 11.2. Reconhecer nas formas de produção regional o Desenvolvimento desigual do território } \\
\text { brasileiro. }\end{array}$ \\
\hline $\begin{array}{l}\text { 12. Nova Ordem } \\
\text { Mundial }\end{array}$ & $\begin{array}{l}\text { 12.1. Analisar em mapas temáticos a nova Ordem ou Desordem Mundial referenciando-se na } \\
\text { lógica da globalização e fragmentação. }\end{array}$ \\
\hline \multirow[t]{2}{*}{$\begin{array}{l}\text { 13. Revolução } \\
\text { técnico-científica }\end{array}$} & $\begin{array}{l}\text { 13.1. Compreender e aplicar noções e conceitos básicos relacionados aos sistemas técnicos em } \\
\text { suas múltiplas temporalidades. }\end{array}$ \\
\hline & $\begin{array}{l}\text { 13.2. Ler e interpretar textos, documentos e vídeos que discutem o avanço técnico e a pesquisa } \\
\text { científica da Terceira revolução industrial. }\end{array}$ \\
\hline \multirow{3}{*}{$\begin{array}{l}\text { 14. Redes } \\
\text { técnicas } \\
\text { das } \\
\text { telecomunicaç } \\
\text { ões }\end{array}$} & $\begin{array}{l}\text { 14.1. Reconhecer a velocidade e eficiência dos transportes e da comunicação em decorrência } \\
\text { do desenvolvimento técnico científico e processo de globalização em curso. }\end{array}$ \\
\hline & 14.2. Diferenciar os processos de tecnificação do espaço em suas temporalidades. \\
\hline & $\begin{array}{l}\text { 14.3. Compreender a modernização resultante da evolução tecnológica, seus conflitos e } \\
\text { contradições, gerados na forma como se distribuem seus benefícios pela humanidade. }\end{array}$ \\
\hline \multirow[t]{2}{*}{$\begin{array}{l}15 . \\
\text { Fragmentação }\end{array}$} & $\begin{array}{l}\text { 15.1. Mapear as áreas de exclusão utilizando textos, gráficos, tabelas, mapas temáticos para } \\
\text { analisar as regiões em conflito no mundo. }\end{array}$ \\
\hline & $\begin{array}{l}\text { 15.2. Analisar os fenômenos culturais, ambientais e econômicos que conferem identidade às } \\
\text { manifestações de regionalização e fragmentação no espaço mundial. }\end{array}$ \\
\hline \multirow[t]{3}{*}{ XI. Fronteiras } & $\begin{array}{l}\text { - Identificar e mapear as fronteiras políticas, raciais, econômicas, religiosas, linguísticas, } \\
\text { localizando suas territorialidades e desterritorialidades. }\end{array}$ \\
\hline & $\begin{array}{l}\text {-Problematizar as questões raciais, políticas, religiosas e de gênero analisando suas } \\
\text { repercussões em escala nacional, local e internacional. }\end{array}$ \\
\hline & $\begin{array}{l}\text { - Prognosticar sobre o futuro dos países em crise e conflito de fronteiras, relacionando seus } \\
\text { problemas territoriais, econômicos e culturais com o processo de fragmentação mundial. }\end{array}$ \\
\hline \multirow{3}{*}{$\begin{array}{l}\text { XII. Impactos } \\
\text { ambientais e } \\
\text { sustentabilidade }\end{array}$} & $\begin{array}{l}\text { Ler e interpretar documentos que discutem os impactos negativos da globalização econômica } \\
\text { na paisagem natural e cultural, propondo alternativas de uso sustentável do planeta Terra. }\end{array}$ \\
\hline & $\begin{array}{l}\text { - Avaliar a qualidade de vida resultante dos avanços tecnológicos, tendo como referência o uso } \\
\text { sustentável dos recursos do planeta. }\end{array}$ \\
\hline & $\begin{array}{l}\text { - Identificar o uso sustentável dos recursos naturais e culturais por empresas que atuam no } \\
\text { terceiro setor, modificando o comportamento empresarial diante da necessidade de processos } \\
\text { ambientalmente mais sustentáveis. }\end{array}$ \\
\hline \multirow[t]{3}{*}{$\begin{array}{l}\text { XIII. Território e } \\
\text { redes }\end{array}$} & $\begin{array}{l}\text {-Identificar o conceito de território explicando-o através das noções de exclusão, marginalização, } \\
\text { segregação, identidade, relacionando-o à complexidade dos cotidianos das cidades em suas } \\
\text { divisões e demarcações espaciais. }\end{array}$ \\
\hline & $\begin{array}{l}\text { - Localizar em fotos os fenômenos da simultaneidade e instantaneidade das informações e } \\
\text { compreender a importância desses recursos no entendimento das paisagens excluídas ou } \\
\text { desterritorializadas e incluídas ou territorializadas. }\end{array}$ \\
\hline & $\begin{array}{l}\text { - Compreender o papel das redes virtuais na vida dos adolescentes e analisar a exclusão e a } \\
\text { inclusão digital. }\end{array}$ \\
\hline \multirow[t]{3}{*}{$\begin{array}{l}\text { XIV. } \\
\text { Globalização }\end{array}$} & $\begin{array}{l}\text {-Ler, analisar e interpretar os códigos específicos da Geografia (mapas, gráficos, tabelas etc.), } \\
\text { na representação dos fatos e fenômenos relacionados à globalização política, econômica, } \\
\text { cultural. }\end{array}$ \\
\hline & $\begin{array}{l}\text { - Selecionar temas e aspectos da espacialidade das cidades que informam as transformações } \\
\text { sob a ótica da globalização. }\end{array}$ \\
\hline & $\begin{array}{l}\text { - Analisar e comparar as singularidades e generalidades de cada lugar, paisagem, território, } \\
\text { região no processo de globalização. }\end{array}$ \\
\hline \multirow[t]{3}{*}{$\begin{array}{l}\text { XV. Diversidade } \\
\text { cultural }\end{array}$} & $\begin{array}{l}\text {-Localizar, identificar e descrever os fenômenos relevantes da paisagem cultural que se } \\
\text { expressam no movimento da globalização. }\end{array}$ \\
\hline & $\begin{array}{l}\text {-Reconhecer os fenômenos culturais que explicam as identidades regionais de vários povos da } \\
\text { Terra avaliando-os em relação à sua extinção e descaracterização do modo de vida. }\end{array}$ \\
\hline & $\begin{array}{l}\text {-Entender como os povos do Equador, dos desertos quentes e gelados, constroem suas } \\
\text { identidades com as paisagens e as regiões demarcando sua territorialidade e espacialidade. }\end{array}$ \\
\hline
\end{tabular}


- Eixo temático IV: Tema 4: Ambiente, tecnologia e sustentabilidade

Temas complementares:

- Políticas nacionais do Programa da Biodiversidade e recomendações da Agenda

21: reflexões para estudos de caso no(s) município(s) mineiro(s).

- Aspectos necessários à construção de cidades sustentáveis.

Meio Ambiente e Cidadania Planetária

\begin{tabular}{|c|c|}
\hline $\begin{array}{l}\text { TÓPICOS / } \\
\text { HABILIDADES }\end{array}$ & DETALHAMENTO DAS HABILIDADES \\
\hline \multirow{2}{*}{$\begin{array}{l}16 . \\
\text { Desenvolvimento } \\
\text { sustentável }\end{array}$} & $\begin{array}{l}\text { 16.1. Explicar a relação existente entre o consumo da natureza e a sustentabilidade } \\
\text { ambiental. }\end{array}$ \\
\hline & $\begin{array}{l}\text { 16.2. Diferenciar as características técnicas dos produtos alimentícios de origem } \\
\text { agroecológica daqueles de uma lavoura convencional. }\end{array}$ \\
\hline \multirow[t]{2}{*}{$\begin{array}{l}\text { 17. Indústria e } \\
\text { meio } \\
\text { Ambiente }\end{array}$} & $\begin{array}{l}\text { 17.1. Identificar e avaliar o comportamento das empresas diante da necessidade de se utilizar } \\
\text { processos ambientalmente mais sustentáveis, tais como, o uso do solo, do subsolo, das } \\
\text { águas. }\end{array}$ \\
\hline & $\begin{array}{l}\text { 17.2. Identificar e analisar os fatores geoestratégicos que vêm determinando os espaços } \\
\text { inteligentes da indústria de alta tecnologia e suas novas exigências socioculturais. }\end{array}$ \\
\hline \multirow[t]{2}{*}{$\begin{array}{l}\text { 18. Cidades } \\
\text { sustentáveis }\end{array}$} & $\begin{array}{l}\text { 18.1. Explicar o significado do Orçamento Participativo, Plano Diretor e o Código de Posturas } \\
\text { avaliando as ações de implementação em seu município. }\end{array}$ \\
\hline & $\begin{array}{l}\text { 18.2. Identificar e explicar os desafios a serem superados no caminho construtivo de cidades } \\
\text { sustentáveis. }\end{array}$ \\
\hline \multirow[t]{2}{*}{ 19. Agenda 21} & $\begin{array}{l}\text { 19.1. Conhecer na Agenda XXI, a importância de suas diretrizes, na construção de } \\
\text { sociedades sustentáveis. }\end{array}$ \\
\hline & 19.2. Analisar as políticas públicas que compõem o Programa Nacional da Biodiversidade. \\
\hline \multirow{3}{*}{$\begin{array}{l}\text { 20. Padrão de } \\
\text { produção e } \\
\text { consumo }\end{array}$} & $\begin{array}{l}\text { 20.1. Identificar os padrões de produção e consumo em diversas dimensões escalares } \\
\text { avaliando-os sob a ótica da sustentabilidade. }\end{array}$ \\
\hline & $\begin{array}{l}\text { 20.2. Explicar a relação entre padrão de consumo, desequilíbrios dos ecossistemas terrestres } \\
\text { e problemas ambientais contemporâneos. }\end{array}$ \\
\hline & $\begin{array}{l}\text { 20.3. Reconhecer padrões de produção e de consumo que têm tido como modelo um estilo } \\
\text { poluidor e consumista. }\end{array}$ \\
\hline \multirow[t]{2}{*}{$\begin{array}{l}\text { XVI. Sociedades } \\
\text { sustentáveis }\end{array}$} & $\begin{array}{l}\text { - Avaliar alternativas de combate à exclusão social em nível escalar referenciando-se em } \\
\text { modelos de desenvolvimento social politicamente sustentáveis. }\end{array}$ \\
\hline & $\begin{array}{l}\text { - Criticar o uso e o abuso de atratividades naturais e culturais pelo turismo de massa } \\
\text { avaliando formas sustentáveis de relacionamento entre turista e meio ambiente. }\end{array}$ \\
\hline \multirow[t]{3}{*}{$\begin{array}{l}\text { XVII. Ordem } \\
\text { Ambiental } \\
\text { Internacional }\end{array}$} & $\begin{array}{l}\text { Explicar, no contexto do Protocolo de Kyoto, as vantagens de países emergentes, como o } \\
\text { Brasil, participarem do Programa "sequestro de carbono". }\end{array}$ \\
\hline & $\begin{array}{l}\text {-Identificar as políticas estabelecidas pela Conferência das Nações Unidas para o Meio } \\
\text { Ambiente e o Desenvolvimento - CNUMAD - sobre mudanças climáticas avaliando os } \\
\text { resultados do Protocolo de Kyoto em nível nacional e planetário. }\end{array}$ \\
\hline & $\begin{array}{l}\text {-Explicar a importância da Conferência das Nações Unidas para o Meio Ambiente e o } \\
\text { Desenvolvimento - CNUMAD - na difusão da temática ambiental em nível planetário e como } \\
\text { sistematizadora de uma ordem ambiental que regula as ações humanas e os impactos } \\
\text { gerados por ela no ambiente. }\end{array}$ \\
\hline \multirow[t]{2}{*}{$\begin{array}{l}\text { XVIII. Políticas } \\
\text { públicas e meio } \\
\text { ambiente no Brasil }\end{array}$} & $\begin{array}{l}\text {-Identificar as políticas públicas do Brasil que regulam o uso e o consumo de recursos hídricos } \\
\text { analisando a atuação dos órgãos governamentais responsáveis por elas. }\end{array}$ \\
\hline & $\begin{array}{l}\text {-Explicar a questão da biossegurança no âmbito da CNUMAD avaliando seus avanços e } \\
\text { retrocessos no cenário político e científico nacional. }\end{array}$ \\
\hline
\end{tabular}




\begin{tabular}{|c|c|}
\hline & $\begin{array}{l}\text {-Avaliar as políticas públicas que regulam o comportamento das empresas em território } \\
\text { nacional diante da necessidade de processos ambientalmente mais sustentáveis. }\end{array}$ \\
\hline $\begin{array}{l}\text { XIX. Revolução } \\
\text { técnico-científica }\end{array}$ & $\begin{array}{l}\text { - Interpretar, através de mapas, gráficos e tabelas fenômenos sócio-espaciais relacionados à } \\
\text { revolução tecnocientífica em curso no planeta. } \\
\text { - Identificar, através de dados da mídia, os fenômenos da simultaneidade e instantaneidade } \\
\text { dos meios de comunicação, dimensionando a territorialidade das multinacionais no avanço } \\
\text { dessas tecnologias. } \\
\text { - Avaliar as implicações socioespaciais da revolução tecnocientífi ca com base em dados do } \\
\text { Índice de Desenvolvimento Humano (IDH) no decorrer da última década. }\end{array}$ \\
\hline XX. Globalização & $\begin{array}{l}\text { - Relacionar o fenômeno da globalização com um novo capitalismo, analisando-o de acordo } \\
\text { com suas três características fundamentais: atividades econômicas globais; fatores de } \\
\text { produtividade e competitividade baseados na inovação, geração de conhecimentos e } \\
\text { processamento de informações; estruturação em torno de redes de fluxos financeiros. } \\
\text { - Identificar e localizar, nas múltiplas redes técnicas presentes no município e no Estado de } \\
\text { Minas Gerais, o movimento da globalização. } \\
\text { - Explicar os conflitos resultantes da má distribuição ecológica e econômica do patrimônio } \\
\text { natural e material, produzindo riqueza e pobreza como efeitos da degradação ambiental, sob a } \\
\text { ótica da ordem política e econômico-financeira internacional globalizada. }\end{array}$ \\
\hline
\end{tabular}

Fonte: Minas Gerais (2005, 25-39). 
ANEXO F: CBC Ensino Médio: Eixos temáticos

- Eixo temático I: Tema 1: O processo de urbanização contemporâneo: a cidade, a metrópole, o trabalho, o lazer e a cultura

Problemas e perspectivas do urbano

\begin{tabular}{|c|c|}
\hline $\begin{array}{l}\text { TÓPICOS / } \\
\text { HABILIDADES }\end{array}$ & DETALHAMENTO DAS HABILIDADES \\
\hline $\begin{array}{l}\text { 1. Espaço urbano } \\
\text { 1.1. Compreender a } \\
\text { relação entre o } \\
\text { crescimento urbano e as } \\
\text { mudanças na vida das } \\
\text { cidades. }\end{array}$ & $\begin{array}{l}\text { 1.1.1. Interpretar os desdobramentos das práticas socioespaciais no } \\
\text { processo de urbanização contemporâneo, tais como: o turismo, o lazer e a } \\
\text { cultura. }\end{array}$ \\
\hline $\begin{array}{l}\text { 2. Cidade e metrópole } \\
\text { 2.1. Compreender os } \\
\text { fenômenos urbanos } \\
\text { relacionados à } \\
\text { metropolização. }\end{array}$ & $\begin{array}{l}\text { 2.1.1. Analisar as situações que explicam a distribuição, localização e } \\
\text { frequência das atividades que evidenciam "vida } 24 \text { horas", tais como } \\
\text { serviços de saúde, "deliverys", hipermercados. } \\
2.1 .2 \text {. Reconhecer singularidades e contradições expressas nas } \\
\text { espacialidades urbanas, tais como: acampamentos, sem-teto, centros de } \\
\text { reciclagem, "shoppings" populares, aglomerados. }\end{array}$ \\
\hline $\begin{array}{l}\text { 3. Território e } \\
\text { territorialidade } \\
\text { 3.1. Compreender as } \\
\text { mudanças nas relações } \\
\text { de trabalho na cidade. }\end{array}$ & $\begin{array}{l}\text { 3.1.1. Relacionar o índice de emprego e desemprego às mudanças } \\
\text { estruturais, em processo, no mundo do trabalho. } \\
\text { 3.1.2. Relacionar o crescimento da economia informal com o surgimento } \\
\text { de novas territorialidades, como a dos camelôs, e espacialidades, como os } \\
\text { shoppings populares. }\end{array}$ \\
\hline $\begin{array}{l}\text { 4. Redes e região } \\
\text { 4.1. Reconhecer na } \\
\text { hierarquia urbana as } \\
\text { funções e centralidades } \\
\text { das redes. }\end{array}$ & $\begin{array}{l}\text { 4.1.1. Reconhecer as relações das metrópoles com as cidades globais } \\
\text { como poderosos entroncamentos de múltiplas redes, tais como, o mercado } \\
\text { financeiro e as telecomunicações. }\end{array}$ \\
\hline
\end{tabular}

- Eixo temático II: Tema 2: As novas territorialidades no campo: as transformações do mundo rural

\begin{tabular}{|c|c|}
\hline $\begin{array}{l}\text { TÓPICOS / } \\
\text { HABILIDADES }\end{array}$ & DETALHAMENTO DAS HABILIDADES \\
\hline $\begin{array}{l}\text { 5. Espacialidade rural } \\
\text { 5.1. Reconhecer os fenômenos } \\
\text { espaciais que evidenciam as } \\
\text { transformações no mundo } \\
\text { rural. }\end{array}$ & $\begin{array}{l}\text { 5.1.1. Interpretar textos, mapas, gráficos, imagens, charges e tabelas como } \\
\text { formas de representação dos fenômenos espaciais que expressam as } \\
\text { transformações da vida no campo. }\end{array}$ \\
\hline $\begin{array}{l}\text { 6. Produção e tecnologia no } \\
\text { campo } \\
6.1 \text { Compreender a } \\
\text { organização da produção } \\
\text { agropecuária sob a ótica da } \\
\text { tradição, da modernidade e da } \\
\text { sustentabilidade ambiental. }\end{array}$ & $\begin{array}{l}\text { 6.1.1. Avaliar as transformações no mundo rural brasileiro a partir do crescimento } \\
\text { do agronegócio. } \\
\text { 6.1.2. Criticar os impasses na Organização Mundial do Comércio (OMC) no que } \\
\text { diz respeito à inserção de agroprodutos dos países emergentes no mercado dos } \\
\text { países ricos. } \\
\text { 6.1.3. Analisar a participação das multinacionais no campo e seu papel nas } \\
\text { exportações brasileiras. }\end{array}$ \\
\hline $\begin{array}{l}\text { 7. Desenvolvimento } \\
\text { sustentável no campo } \\
7.1 \text {. Compreender a re- } \\
\text { apropriação da Natureza na } \\
\text { perspectiva de valores } \\
\text { relacionados à diversidade } \\
\text { biológica, heterogeneidade } \\
\text { cultural, pluralidade política e } \\
\text { democracia participativa. }\end{array}$ & $\begin{array}{l}\text { 7.1.1. Reconhecer a região do cerrado brasileiro como espaço de produção, } \\
\text { decorrente da implantação das novas tecnologias, avaliando seus impactos } \\
\text { ambientais na ótica da sustentabilidade. } \\
\text { 7.1.2. Identificar na agricultura familiar o uso de técnicas agroecológicas, a } \\
\text { produção de alimentos orgânicos e a organização em cooperativas. }\end{array}$ \\
\hline
\end{tabular}

- Eixo temático III: Tema 3: A Relação sociedade e natureza em questão: mutações no mundo natural 
TÓPICOS /

HABILIDADES

8. Fontes de energia 8.1. Compreender os impasses da sociedade contemporânea sob a ótica da produção e do consumo de energia.

8.2. Compreender a
geopolítica do petróleo e do
gás natural no contexto
contemporâneo.

Internacional
9.1 Reconhecer na
sociedade global
instrumentos de políticas
ambientais.

10. Aquecimento global 10.1. Explicar os desdobramentos da matriz energética da sociedade industrial, considerando seus impactos sobre 0 aquecimento global.

11. Domínios de natureza no Brasil

11.1. Reconhecer os domínios de natureza que compõem o território brasileiro, avaliando a interferência humana na exploração de seus recursos.

\section{DETALHAMENTO DAS HABILIDADES}

8.1.1. Comparar dados de mapas temáticos, gráficos, imagens, textos e tabelas sobre a atual matriz energética da sociedade industrial (hidrocarbonetos e gás natural, biomassa, carvão mineral, álcool etílico, nuclear, hidráulica, eólica, solar, geotérmica), segundo os parâmetros da sustentabilidade ambiental.

8.1.2. Localizar a distribuição do uso de tecnologias energéticas limpas (solar, eólica e geotérmica) e de tecnologias alternativas (álcool etílico, biomassa, nuclear, Hbio, biodiesel), avaliando os impactos ambientais gerados pelas tecnologias alternativas.

8.2.1. Explicar a geopolítica do petróleo contextualizando-a no atual cenário de distribuição espacial, produção, consumo, comércio e reservas.

8.2.2. Explicar a geopolítica do gás natural na América do Sul, no atual cenário de distribuição espacial, reservas, produção, consumo e comércio.

9.1.1. Confrontar as políticas públicas a respeito das fontes energéticas com o compromisso do governo brasileiro frente aos acordos firmados nas rodadas de negociações da Ordem Ambiental Internacional.

9.1.2. Problematizar o renascimento do uso da energia nuclear como alternativa de contenção de emissões de gases de efeito estufa.

9.1.3. Avaliar o uso, o consumo e a geopolítica da água e as políticas ambientais a ela relacionadas.

10.1.1. Avaliar as mudanças climáticas a partir do aquecimento global.

10.1.2. Compreender a polêmica que envolve os problemas de natureza socioambiental e econômica em torno da matriz energética da sociedade industrial versus aquecimento global.

11.1.1. Avaliar os domínios da Caatinga e do Cerrado sob a ótica da originalidade climática, hidrológica e pedológica, relacionando as possibilidades e os limites de seu uso pela agricultura.

11.1.2. Interpretar textos, mapas, gráficos e tabelas que tratam da indústria extrativa mineral brasileira, segundo sua localização, empresas, reservas e contribuição no PIB.

- Eixo temático IV: Tema 4: As novas fronteiras do capitalismo global: os territórios nas novas regionalizações: cenários da globalização e fragmentação

\begin{tabular}{l|l}
\hline $\begin{array}{l}\text { TÓPICOS / } \\
\text { HABILIDADES }\end{array}$ & DETALHAMENTO DAS HABILIDADES \\
\hline $\begin{array}{l}\text { 12. Globalização e } \\
\text { regionalização } \\
\text { 12.1. Compreender a } \\
\text { produção do espaço na } \\
\text { tensão da globalização e } \\
\text { da fragmentação. }\end{array}$ & $\begin{array}{l}\text { 12.1.1. Reconhecer as novas ordens e desordens política, econômica e } \\
\text { cultural decorrentes das relações de poder em diferentes formas de } \\
\text { regionalização do espaço mundial, tais como: blocos econômicos; } \\
\text { aglomerados de exclusão asiático, africano, latino-americano; territórios } \\
\text { múltiplos do terrorismo e do genocídio. } \\
\text { 12.1.2. Interpretar na mídia impressa, visual e digital as representações } \\
\text { das novas regionalizações do espaço na fragmentação, tais como } \\
\text { conflitos e migrações. }\end{array}$ \\
\hline $\begin{array}{l}\text { 13.1.1. Interpretar a expansão econômica da China no comércio mundial, } \\
\text { analisando sua produção no ranking do capitalismo global. } \\
\text { Internacional Comércio de } \\
\text { 13.1. Compreender a } \\
\text { organização do capital no } \\
\text { espaço da produção } \\
\text { global. }\end{array}$ & $\begin{array}{l}\text { industriais na nova dinâmica do capitalismo informacional e global. } \\
\text { espaço da produção, segundo as fronteiras flexíveis da globalização. }\end{array}$ \\
\hline
\end{tabular}




\begin{tabular}{l|l}
\hline 14. Reordenamento do & 14.1.1. Analisar o reordenamento espacial das indústrias de alta \\
território & tecnologia no território brasileiro, avaliando suas possibilidades e limites \\
14.1. Explicar os novos & no contexto das novas fronteiras do capitalismo global. \\
ordenamentos espaciais \\
exigidos pelas indústrias \\
de alta tecnologia.
\end{tabular}

Fonte: Minas Gerais, (2005: 55-59). 
ANEXO G: Conteúdo complementar de Geografia: Eixos temáticos

- Eixo Temático V: Tema 5: O Processo de Urbanização Contemporâneo: a Cidade, a Metrópole, o Trabalho, o Lazer

Subtemas: - A cidade e a metrópole sob a ótica das políticas urbanas e do Estatuto da Cidade - O espaço público e as interações sociais: a cultura e a identidade expressas nos fenômenos urbanos. - Os conflitos entre público e privado na cidade contemporânea: as relações entre civilidade e cidadania.

\section{Problemas e Perspectivas do Urbano}

\begin{tabular}{|c|c|}
\hline TÓPICOS / HABILIDADES & DETALHAMENTO DAS HABILIDADES \\
\hline $\begin{array}{l}\text { 15. Produção e Consumo } 15.1 \text {. } \\
\text { Relacionar produção e } \\
\text { consumo para avaliar a } \\
\text { qualidade de vida no ambiente } \\
\text { urbano }\end{array}$ & $\begin{array}{l}\text { 15.1.1. Reconhecer as contradições nas formas de apropriação dos } \\
\text { novos mercados de produtos ecologicamente corretos pelo } \\
\text { capitalismo global. }\end{array}$ \\
\hline $\begin{array}{l}\text { 16. Políticas Públicas Urbanas: } \\
\text { o público e o privado } \\
\text { 16.1. Avaliar a relação entre as } \\
\text { políticas públicas e a produção } \\
\text { do espaço urbano. }\end{array}$ & $\begin{array}{l}\text { 16.1.1. Reconhecer a presença/ausência população de sem-teto, } \\
\text { sem-trabalho, sem-educação, sem-saúde, sem-terra, questionando } \\
\text { os direitos à cidadania. }\end{array}$ \\
\hline $\begin{array}{l}\text { 17. Espacialidade urbana } \\
\text { 17.1. Compreender as } \\
\text { práticas sociais espacializadas } \\
\text { na complexidade da vida na } \\
\text { metrópole nos países centrais } \\
\text { e periféricos. }\end{array}$ & $\begin{array}{l}\text { 17.1.1. Analisar textos e imagens sobre os fenômenos da } \\
\text { metropolização: fluxo de pessoas, serviços, especulação imobiliária, } \\
\text { lazer. }\end{array}$ \\
\hline $\begin{array}{l}\text { 18. Gestão da cidade } \\
\text { 18.1. Avaliar o crescimento } \\
\text { populacional e suas } \\
\text { implicações na gestão da } \\
\text { cidade nos países centrais e } \\
\text { periféricos. } \\
\text { 4.1. Reconhecer na hierarquia } \\
\text { urbana as funções e } \\
\text { centralidades das redes. }\end{array}$ & $\begin{array}{l}\text { 18.1.1. Interpretar a qualidade de vida urbana em mapas temáticos e } \\
\text { textos sobre saneamento básico, lazer, saúde, energia elétrica, } \\
\text { habitação, avaliando as políticas de gestão da cidade. }\end{array}$ \\
\hline
\end{tabular}

- Eixo temático VI: Tema 6: As Novas Territorialidades no Campo Subtemas - A fluidez das fronteiras econômicas, políticas e culturais entre os meios rural e urbano. - A expansão e consolidação do agronegócio em contraposição à manutenção da fome no mundo. - A participação dos agroprodutos no contexto das exportações brasileiras e no PIB. - O desenho do novo rural brasileiro: novas alternativas de produção e manejo (in)sustentável do solo.

As Transformações no Mundo Rural

\section{TÓPICOS /HABILIDADES}

19. Trabalho no campo

19.1. Analisar o sistema de trabalho no campo nos países centrais e periféricos.
DETALHAMENTO DAS HABILIDADES

19.1.1. Reconhecer as principais características da agroindústria e do sistema de trabalho nela existente, explicando as novas relações de trabalho no campo. 
20. Estrutura fundiária

20.1. Confrontar os efeitos das disparidades territoriais e sociais relativas à distribuição da terra e às políticas de desenvolvimento rural nos países centrais e periféricos.

21. Territorialidades no campo 21.1. Avaliar projetos agropecuários nos países centrais e periféricos.

22. Relação campo e cidade 22.1. Reconhecer o significado da identidade do campo e da cidade nas sociedades dos países centrais e periféricos.

23. Reforma agrária e movimentos sociais

23.1. Avaliar os projetos de reforma agrária nos países centrais e periféricos.

24. Espaço rural

24.1. Prognosticar sobre o futuro da produção do espaço rural nos países centrais e periféricos.

25. Diversidade cultural

25.1. Identificar a transformação da identidade cultural da vida no campo em mercadoria.
20.1.1. Analisar as variáveis indicadoras do desenvolvimento humano (saúde, educação, esperança de vida) e a desigualdade da distribuição da posse da terra nos países periféricos, a exemplo do Brasil.

20.1.2. Avaliar as possibilidades e perspectivas de associar a redistribuição de terras com uma política eficaz de combate à pobreza no campo.

21.1.1. Analisar as relações de poder na implantação de projetos agropecuários mineiros, como o Projeto Jaíba, e outros no contexto brasileiro e latino-americano.

22.1.1. Interpretar materiais imagéticos e textos sobre aspectos relevantes dos fenômenos sociais, políticos, econômicos que tratam da relação campo e cidade.

23.1.1. Analisar as origens dos movimentos sociais latinoamericanos no campo, interpretando suas identidades com a terra.

24.1.1. Interpretar a paisagem rural e a nova ruralidade expressa nos fenômenos socioeconômicos e culturais das regiões agropecuárias do Brasil e do mundo.

25.1.1. Reconhecer as possibilidades de ampliação da renda do proprietário rural a partir da transformação da identidade cultural do campo em projetos turísticos.

- Eixo Temático VII: Tema 7: A Relação Sociedade e Natureza em Questão Subtemas - Regiões hidroconflitivas do planeta Terra; - Desertificação climática, desertificação ecológica ; • Megadiversidade brasileira: mito ou realidade?

- Quadrilátero Ferrífero: domínios da natureza e políticas ambientais

Mutações no Mundo Natural

TÓPICOS /HABILIDADES

26. Recursos hídricos 26.1. Avaliar os acordos e controles da gestão ambiental da água.

27. Padrão de produção e consumo 27.1. Prognosticar sobre o futuro do planeta, tendo como referência os padrões de produção e consumo do capitalismo global.

28. Dinâmica terrestre

28.1. Reconhecer os fenômenos responsáveis pela dinâmica terrestre.

\section{Desertificação}

29.1. Reconhecer os processos ecológicos e antrópicos da desertificação.

30. Diversidade biológica 30.1 . Avaliar o potencial da biodiversidade dos ambientes tropicais.
DETALHAMENTO DAS HABILIDADES

26.1.1. Analisar as políticas públicas em nível nacional e internacional para o resguardo do patrimônio ambiental do planeta.

27.1.1. Explicar, na perspectiva da sustentabilidade, os padrões de produção e de consumo que têm referenciado o desenvolvimento econômico do capitalismo global.

28.1.1. Explicar os fenômenos da dinâmica terrestre relacionados ao tectonismo e vulcanismo, tendo como referência o movimento das placas tectônicas.

28.1.2. Explicar os fenômenos relacionados à litosfera, hidrosfera e atmosfera.

29.1.1. Analisar textos, mapas, gráficos, tabelas e imagens sobre a desertificação em processo no Norte de Minas Gerais: área de abrangência, localização geográfica, municípios em situação de risco e suas consequências em âmbito natural, social, urbano, institucional. 29.1.2. Analisar textos, mapas, gráficos, tabelas e imagens sobre a desertificação e arenização em processo no Brasil.

30.1.1. Avaliar os limites e possibilidades do trabalho compartilhado entre Organizações Não Governamentais (ONG) e empresas transnacionais com vistas à manutenção 
- Eixo temático VIII Tema 8: As Novas Fronteiras do Capitalismo Global: os Territórios nas Novas Regionalizações Subtemas: • Globalização e pluralidade cultural; • O papel das instituições internacionais na regulação do território mundial; • As telecomunicações unindo o mundo em redes digitais; • O crescimento dos países emergentes no movimento da globalização

Os Cenários da Globalização e Fragmentação

\begin{tabular}{|c|c|}
\hline & $S$ \\
\hline $\begin{array}{l}\text { 31. Terceiro Setor } \\
\text { 31.1. Reconhecer a impc } \\
\text { terceiro setor e os pr } \\
\text { inclusão social nos países }\end{array}$ & $\begin{array}{l}\text { portadores de informação de tipos de organização, } \\
\text { frequência, distribuição e localização do Terceiro Setor no } \\
\text { Brasil e no mundo. }\end{array}$ \\
\hline $\begin{array}{l}\text { 32. Fluxos Econômicos } \\
\text { 32.1. Analisar os fluxos ecc } \\
\text { que expressam uma territc } \\
\text { visível, tais como: Nafta, } \\
\text { União Europeia, Apec e Asea }\end{array}$ & $\begin{array}{l}\text { 32.1.1. Avaliar as contradições que envolvem a relação } \\
\text { MERCOSUL e ALCA. }\end{array}$ \\
\hline $\begin{array}{l}\text { 33. Desterritorialização e Redes de } \\
\text { Solidariedade } \\
\text { 33.1. Avaliar as possibilidades de } \\
\text { reterritorialização a partir de projetos } \\
\text { de inclusão digital e de estratégias } \\
\text { dos migrantes. }\end{array}$ & $\begin{array}{l}\text { 33.1.1. Identificar o crescimento das redes de } \\
\text { solidariedade no Brasil e no mundo, interpretando sua } \\
\text { interferência na vida dos desterritorializados, } \\
\text { 33.1.2. Analisar a relação entre novas formas de auxílio e } \\
\text { novas formas de dominação e controle na chamada } \\
\text { "sociedade global". }\end{array}$ \\
\hline $\begin{array}{l}\text { 34. Fronteiras } 34.1 . \text { Analisar as } \\
\text { causas e os efeitos da migração } \\
\text { clandestina nos países centrais e } \\
\text { periféricos. }\end{array}$ & $\begin{array}{l}\text { 34.1.1. Avaliar as consequências do fechamento das } \\
\text { fronteiras dos países de maior desenvolvimento } \\
\text { econômico. } \\
\text { 34.1.2. Analisar o deslocamento populacional no jogo de } \\
\text { forças entre globalização e fragmentação. }\end{array}$ \\
\hline $\begin{array}{l}\text { 35. Sociedade da inform } \\
\text { Avaliar a importância } \\
\text { mundiais de informacão } r\end{array}$ & $\begin{array}{l}\text { 35.1.1. Identificar os pontos de interconexão das redes } \\
\text { mundiais de informação com os fluxos do turismo e dos } \\
\text { serviços culturais. }\end{array}$ \\
\hline
\end{tabular}

Fonte: Minas Gerais (2005: 61-66). 
ANEXO H: Núcleos, áreas e disciplinas do PPP 2002 UNIMONTES

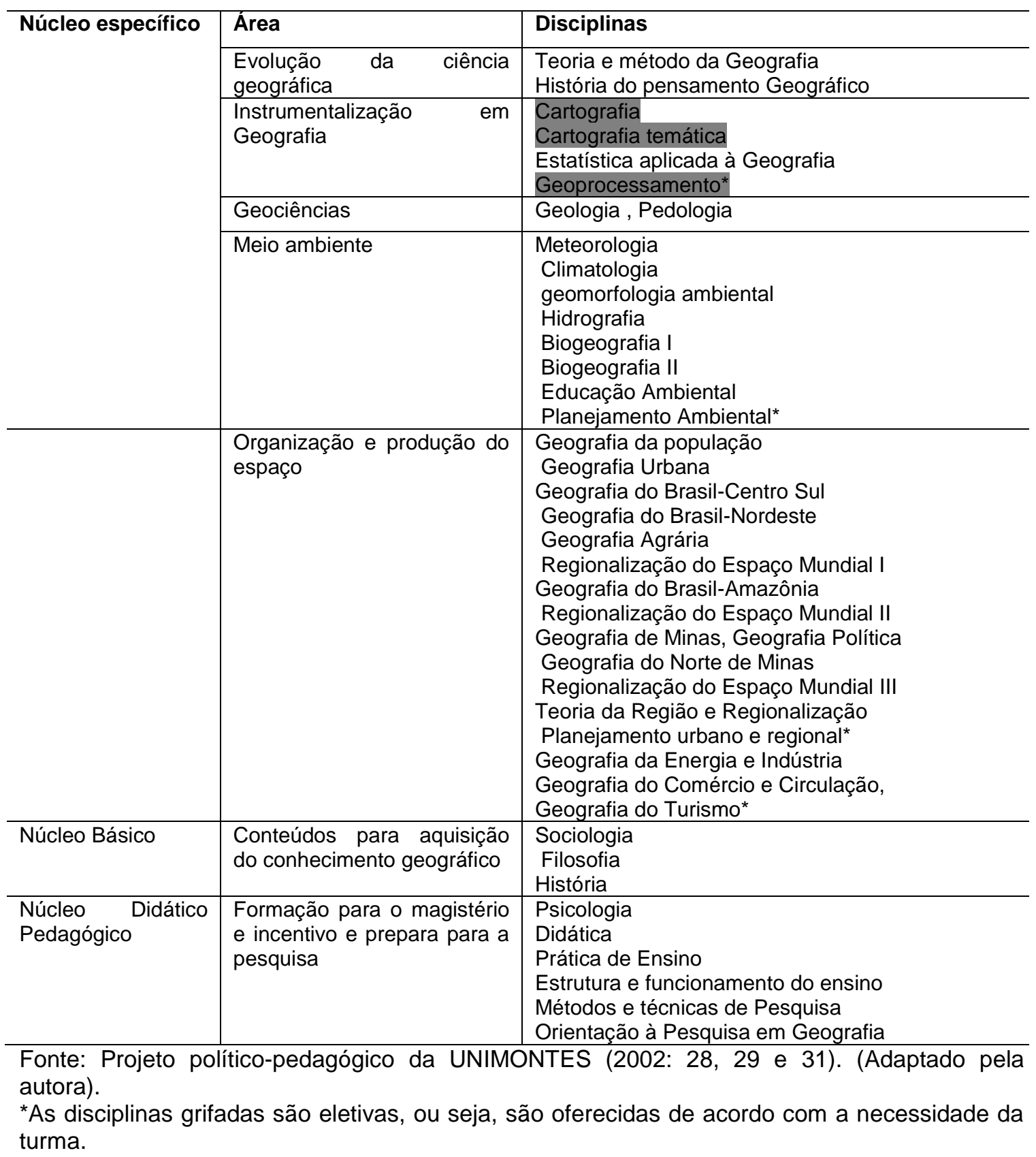


ANEXO I: Núcleos, áreas e disciplinas do PPP 2004 UNIMONTES

\begin{tabular}{|c|c|c|}
\hline \multirow{6}{*}{$\begin{array}{l}\text { 1-NÚCLEO } \\
\text { ESPECÍFICO }\end{array}$} & ÁREA & DISCIPLINA \\
\hline & $\begin{array}{c}\text { Evolução da Ciência } \\
\text { Geográfica }\end{array}$ & História do Pensamento Geográfico \\
\hline & $\begin{array}{c}\text { Instrumentalização em } \\
\text { Geografia }\end{array}$ & $\begin{array}{l}\text { Cartografia } \\
\text { Cartografia Temática } \\
\text { Estatística Aplicada à Geografia } \\
\text { Geoprocessamento* }^{\star} \\
\text { Português Instrumental* }^{*}\end{array}$ \\
\hline & Geociências & Fundamentos de Geologia \\
\hline & Meio Ambiente & $\begin{array}{l}\text { Climatologia } \\
\text { Geomorfologia } \\
\text { Geomorfologia Ambiental } \\
\text { Hidrografia } \\
\text { Biogeografia I } \\
\text { Educação Ambiental } \\
\text { Planejamento Ambiental }{ }^{\star} \\
\end{array}$ \\
\hline & $\begin{array}{c}\text { Organização e } \\
\text { Produção do Espaço }\end{array}$ & $\begin{array}{l}\text { Geografia da População } \\
\text { Geografia Urbana } \\
\text { Geografia do Brasil Centro-Sul } \\
\text { Geografia do Brasil Nordeste } \\
\text { Geografia Agrária } \\
\text { Geografia Política } \\
\text { Geografia do Brasil - Amazônia } \\
\text { Geografia de Minas Gerais } \\
\text { Regionalização do Espaço Mundial I } \\
\text { Geografia do Norte de Minas } \\
\text { Regionalização do Espaço Mundial II } \\
\text { Teoria de Região e Regionalização } \\
\text { Planejamento Urbano e Regional* } \\
\text { Geografia Econômica } \\
\text { Geografia do Turismo* } \\
\end{array}$ \\
\hline $\begin{array}{l}\text { 2-NÚCLEO } \\
\text { BÁSICO }\end{array}$ & Ciências Humanas & $\begin{array}{l}\text { Sociologia } \\
\text { Filosofia } \\
\text { História Econômica } \\
\text { Geografia Cultural } \\
\end{array}$ \\
\hline $\begin{array}{l}\text { 3-NÚCLEO } \\
\text { PEDAGÓGICO }\end{array}$ & Didático-Pedagógico & $\begin{array}{l}\text { Psicologia da Educação } \\
\text { Didática } \\
\text { Prática de Formação } \\
\text { Estrutura e Func. do Ensino Fundamental e Médio } \\
\text { Métodos e Técnicas de Pesquisa } \\
\text { Orientação à Pesquisa Geográfica } \\
\text { Pesquisa em Geografia }\end{array}$ \\
\hline
\end{tabular}

Fonte: PPP (2004, 24-25).

* As disciplinas grifadas são eletivas, ou seja, são oferecidas de acordo com a necessidade da turma. 
ANEXO J: Organização curricular do PPP 2008

\begin{tabular}{|c|c|c|c|c|c|}
\hline \multicolumn{6}{|c|}{ ORGANIZAÇÃO CURRICULAR HORIZONTAL } \\
\hline Períodos & $\begin{array}{l}\text { NÚCLEO/DIMENSÃO FORMADORA } \\
\text { - } \\
\text { Formação Humanística, } \\
\text { Artística, Científica. }\end{array}$ & $\begin{array}{c}\text { NÚCLEO/DIMENSÃO FORMADORA - } \\
\text { Organização do } \\
\text { trabalho Profissional }\end{array}$ & $\begin{array}{l}\text { NÚCLEO/DIMENSÃO } \\
\text { FORMADORA - } \\
\text { Organização do } \\
\text { processo social }\end{array}$ & EIXO INTEGRADOR & $\begin{array}{c}\text { EIXO } \\
\text { TRANSVERSAL }\end{array}$ \\
\hline $\mathbf{1}^{\circ}$ & $\begin{array}{l}\text { - Métodos e Técnicas de Pesquisa } \\
\text { em Geografia }\end{array}$ & $\begin{array}{l}\text { - Geografia Escolar } \\
\text { - Fundamentos de Geologia I } \\
\text { - História do Pensamento Geográfico }\end{array}$ & - Sociologia & $\begin{array}{l}\text { Fundamentos da } \\
\text { Ciência Geográfica }\end{array}$ & \multirow{8}{*}{ 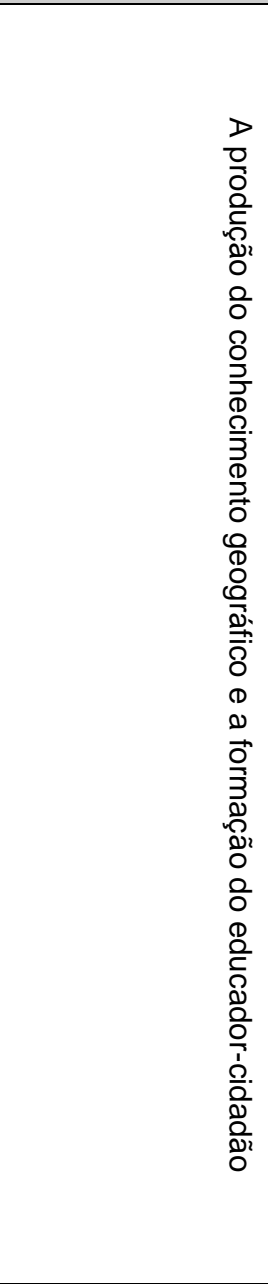 } \\
\hline $2^{\circ}$ & - Filosofia & $\begin{array}{l}\text { - Cartografia } \\
\text { - Climatologia } \\
\text { - Fundamentos de Geologia II } \\
\text { - Teoria e Método da Geografia }\end{array}$ & & $\begin{array}{c}\text { Interação } \\
\text { sociedade-natureza. }\end{array}$ & \\
\hline $3^{\circ}$ & & $\begin{array}{l}\text { - Geocartografia } \\
\text { - Hidrografia } \\
\text { - Didática } \\
\text { - História Econômica } \\
\text { - Geografia da População }\end{array}$ & & $\begin{array}{l}\text { Instrumentalização } \\
\text { para a produção do } \\
\text { conhecimento } \\
\text { geográfico }\end{array}$ & \\
\hline $4^{\circ}$ & - Psicologia & $\begin{array}{l}\text { - Geografia da Energia e Indústria } \\
\text { - Geomorfologia I } \\
\text { - Geografia Rural } \\
\text { - Teoria de Região e Regionalização }\end{array}$ & & $\begin{array}{l}\text { Desenvolvimento } \\
\text { socioeconômico e } \\
\text { gestão do território }\end{array}$ & \\
\hline $5^{\circ}$ & - Orientação à Pesquisa Geográfica & $\begin{array}{l}\text { - Geografia do Brasil/Centro Sul } \\
\text { - Geomorfologia II } \\
\text { - Geografia do Comércio e Circulação } \\
\text { - Estágio Curricular Supervisionado }\end{array}$ & & $\begin{array}{l}\text { Redes e fluxos no } \\
\text { espaço geográfico }\end{array}$ & \\
\hline $6^{\circ}$ & & $\begin{array}{l}\text { - Geografia do Brasil/ Nordeste } \\
\text { - Estágio Curricular Supervisionado } \\
\text { - Geografia Urbana } \\
\text { - Organização do Espaço Mundial I } \\
\text { - Geografia Cultural }\end{array}$ & & $\begin{array}{l}\text { Realidade Social e sua } \\
\text { dinâmica espacial }\end{array}$ & \\
\hline $7^{\circ}$ & & $\begin{array}{l}\text { - Biogeografia } \\
\text { - Geografia do Brasil/Amazônia } \\
\text { - Estágio Curricular Supervisionado } \\
\text { - Organização do Espaço Mundial II } \\
\text { - Geografia de Minas }\end{array}$ & & $\begin{array}{l}\text { Dinâmica do mundo } \\
\text { atual e do Brasil }\end{array}$ & \\
\hline $8^{\circ}$ & - Educação Ambiental & $\begin{array}{l}\text { - Geoprocessamento } \\
\text {-Estrutura e Funcionamento do Ensino } \\
\text { Fundamental e Médio } \\
\text { - Estágio Curricular Supervisionado } \\
\text { - Geografia do Norte de Minas }\end{array}$ & & $\begin{array}{l}\text { Educação, sociedade } \\
\text { e tecnologia }\end{array}$ & \\
\hline
\end{tabular}

Fonte: MINAS GERAIS (2008: 25 
